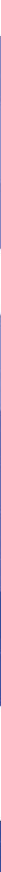

Routledge Studies in Fascism and the Far Right

\title{
THE RIGHT-WING CRITIQUE OF EUROPE
}

\section{NATIONALIST, SOVEREIGNIST AND RIGHT-WING POPULIST ATTITUDES TO THE EU}

Edited by

Joanna Sondel-Cedarmas and Francesco Berti

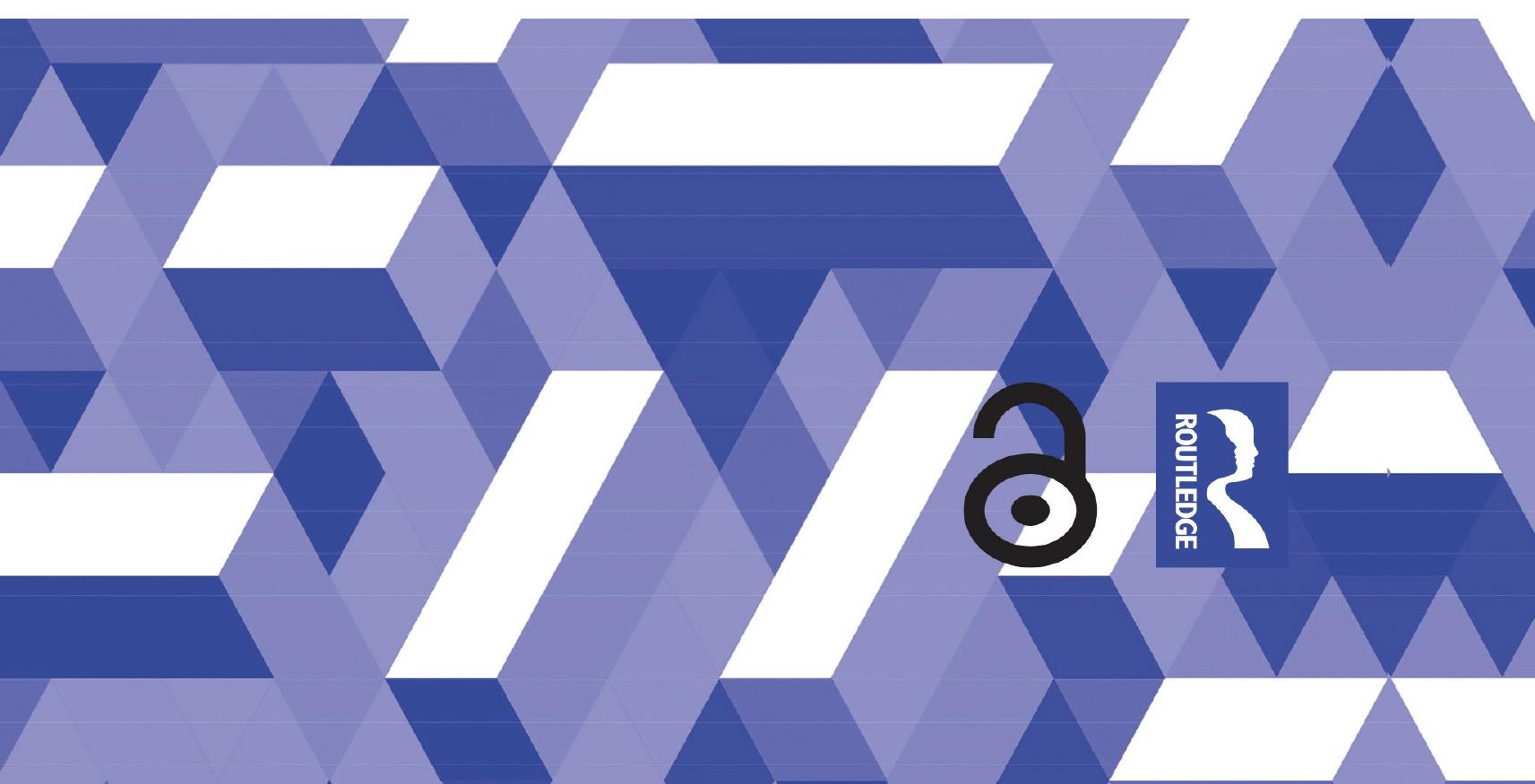




\section{The Right-Wing Critique of Europe}

The Right-Wing Critique of Europe analyses the opposition to the European Union from a variety of right-wing organisations in Western, Central and Eastern Europe.

In recent years, opposition to the processes of globalisation and the programme of closer European integration, understood as a threat to the sovereignty of individual member states, has led to an intensification of Eurosceptic sentiments on the Old Continent. The results of the European parliamentary elections in 2014 and 2019, the Brexit referendum and electoral results in different European countries are all testament to the considerable growth of radical populist-nationalist and conservative-sovereignist movements and parties. The common idea that binds these groups, both in Western Europe and in Central and Eastern Europe, is a hostile attitude towards the idea of (an ever-more integrated) united Europe. These parties reject not only the project of building a European federation, but also the current model of the European Union and the values underlying its attitudes. They are united by their criticism of EU policies, in particular those concerning security, emigration, multiculturalism, gender equality and the rights of minorities, as well as economic liberalism and the common currency. However, this criticism manifests itself with varying degrees of intensity, and not all parties fit the classic definition of Euroscepticism but instead represent its mild form, Eurorealism. The authors bring together reflections on the organic and complex critique of the European Union, its policies and cultural and ideological character. The book provides a comparative analysis of this criticism at the transnational level.

This book will be of interest to researchers of European politics, the radical right and Euroscepticism.

Joanna Sondel-Cedarmas is Associate Professor of Political Science at the Jagiellonian University in Kraków, Poland. Her research interests include nationalism, fascism and the far right, as well as memory of totalitarianism and authoritarianism.

Francesco Berti is Associate Professor of the History of Political Doctrines at the University of Padova, Italy. Among other subjects, he has published on nationalism and the Shoah. 


\section{Routledge Studies in Fascism and the Far Right}

Series editors

Nigel Copsey, Teesside University, UK and Graham Macklin, Center for

Research on Extremism (C-REX), University of Oslo, Norway.

This book series focuses upon national, transnational and global manifestations of fascist, far right and right-wing politics primarily within a historical context but also drawing on insights and approaches from other disciplinary perspectives. Its scope also includes anti-fascism, radical-right populism, extreme-right violence and terrorism, cultural manifestations of the far right, and points of convergence and exchange with the mainstream and traditional right.

Titles include:

Male Supremacism in the United States

From Patriarchal Traditionalism to Misogynist Incels and the Alt-Right Edited by Emily K. Carian, Alex DiBranco and Chelsea Ebin

\section{The Fascist Faith Of Romania's Legion "Archangel Michael" in Romania, 1927-41 \\ Martyrdom to National Purification \\ Constantin Iordachi}

\section{The Blackshirts' Dictatorship}

Armed Squads, Political Violence, and the Consolidation of Mussolini's Regime

Matteo Millan

\section{Fascism in Brazil}

From Integralism to Bolsonarism

Leandro Pereira Gonçalves and Odilon Caldeira Neto

\section{The Right-Wing Critique of Europe}

Nationalist, Sovereignist and Right-Wing Populist Attitudes to the EU Joanna Sondel-Cedarmas and Francesco Berti

For more information about this series, please visit: www.routledge.com/ Routledge-Studies-in-Fascism-and-the-Far-Right/book-series/FFR 


\section{The Right-Wing Critique of Europe}

Nationalist, Sovereignist and

Right-Wing Populist Attitudes

to the EU

\section{Edited by}

Joanna Sondel-Cedarmas and Francesco Berti 
First published 2022

by Routledge

4 Park Square, Milton Park, Abingdon, Oxon OX14 4RN

and by Routledge

605 Third Avenue, New York, NY 10158

Routledge is an imprint of the Taylor \& Francis Group, an informa business

(C) 2022 selection and editorial matter, Joanna Sondel-Cedarmas and

Francesco Berti; individual chapters, the contributors

The right of Joanna Sondel-Cedarmas and Francesco Berti to be identified as the authors of the editorial material, and of the authors for their individual chapters, has been asserted in accordance with sections 77 and 78 of the Copyright,

Designs and Patents Act 1988.

The Open Access version of this book, available at www.taylorfrancis.com, has been made available under a Creative Commons Attribution-Non Commercial-No Derivatives 4.0 license.

The open access license of the publication was funded by the Priority Research Area Society of the Future under the programme "Excellence Initiative - Research University" at the Jagiellonian University in Krakow.

Trademark notice: Product or corporate names may be trademarks or registered trademarks, and are used only for identification and explanation without intent to infringe.

British Library Cataloguing-in-Publication Data

A catalogue record for this book is available from the British Library

Library of Congress Cataloging-in-Publication Data

Names: Sondel-Cedarmas, Joanna, 1975- editor. | Berti, Francesco, editor.

Title: The right-wing critique of Europe : nationalist, souverainist and right-wing populist attitudes to the EU / edited by Joanna Sondel-Cedarmas and Francesco Berti.

Description: Abingdon, Oxon ; New York, NY : Routledge, 2022. |

Series: Routledge studies in fascism and the far right |

Includes bibliographical references and index.

Identifiers: LCCN 2021035916 (print) | LCCN 2021035917 (ebook) |

ISBN 9781032126852 (hardback) | ISBN 9781032127637 (paperback) |

ISBN 9781003226123 (ebook)

Subjects: LCSH: Populism-European Union countries. |

Nationalism-European Union countries. | Political parties-European

Union countries. | European federation-Public opinion. |

European Union-Public opinion. | European Union countries-Politics

and government-21st century.

Classification: LCC JN40 .R537 2022 (print) |

LCC JN40 (ebook) | DDC 341.242/2-dc23

LC record available at https://lccn.loc.gov/2021035916

LC ebook record available at https://lccn.loc.gov/2021035917

ISBN: 978-1-032-12685-2 (hbk)

ISBN: 978-1-032-12763-7 (pbk)

ISBN: 978-1-003-22612-3 (ebk)

DOI: $10.4324 / 9781003226123$

Typeset in Times New Roman

by Newgen Publishing UK 


\section{Contents}

List of figures viii

List of tables $\quad$ ix

Notes on contributors $\quad \mathrm{x}$

Introduction 1

JOANNA SONDEL-CEDARMAS AND FRANCESCO BERTI

\section{PART I}

Current nationalisms and the European integration process

1 Against Europe or against Germany? European integration and Germanophobia in France, Great Britain and Italy

DANIELE PASQUINUCCI

2 Right-wing populism, Euroscepticism, and neo-traditionalism in Central and Eastern Europe ZDZISŁAW MACH

\section{PART II}

Nationalist, sovereignist and national-populist parties in Europe

3 The nationalism of the New Right in the Federal Republic of Germany MAREK MACIEJEWSKI

4 Pro-European, anti-EU? The National Rally and European integration 
vi Contents

5 Giorgia Meloni's new Europe: Europe of sovereign nations in the Brothers of Italy party manifestos

JOANNA SONDEL-CEDARMAS

6 The League of Salvini: from a Europe of regions to a Europe of nations

GIANLUCA PASSARELLI AND DARIO TUORTO

7 English nationalism and its role in building support for Brexit: the case of UKIP and the Brexit Party MARCIN GALENT

8 Ally, opponent or means to an end? The role of the European Union in the Catalan independence process AGNIESZKA GRZECHYNKA

9 'Poland in Europe, Europe for Poland': national populist narratives on the example of Kukiz'15 MAŁGORZATA MARIA FIJA

10 Considerations on the role of Hungary and the Hungarian nation in the European Union after 1989 TADEUSZ KOPYŚ

11 Between the past and the future: Eurosceptic political parties and the EU integration of Serbia NATASZA STYCZYŃSKA AND HARIS DAJČ

12 Main varieties of Russian nationalism in the post-Soviet period and their relationship to European heritage and contemporariness

JOACHIM DIEC

\section{PART III}

\section{Right-wing populist attitudes towards the $\mathbf{E U}$}

13 United in diversity? The preferences of populist parties in the European Parliament 
14 (Momentarily) drifting into ideocracy in Central Europe: the case of Law and Justice and Fidesz GRZEGORZ POŻARLIK

15 A European legal war? Nationalist populism, the rule of law and the language of constitutionalism PRZEMYSŁAW TACIK

16 Between patriotism and nationalism: national identity in the education policy of Law and Justice. Comments on the 2017 education reform

ELŻBIETA M. MACH

\section{PART IV}

By way of a conclusion

17 Pope Francis on Europe

EWA KOZERSKA

Index 


\section{Figures}

6.1 Left-right self-placement, voters for the League, for other centre-right parties and all voters. Period 1994-2018

13.1 Number of populist parties in each European political group (VIII and IX legislatures) 


\section{Tables}

6.1 Sociodemographic profiles: age, occupational status, social class (\%) $\quad 84$

6.2 Positions on European integration and the euro (\%) 84

6.3 Positions on economic issues 86

11.1 Outcomes of parliamentary elections in Serbia (Eurosceptic parties) 151

13.1 Populist parties' seats in the EP (VIII and IX legislatures) 189

13.2 Number of populist parties in the EP (VIII and IX $\begin{array}{ll}\text { legislatures) } & 189\end{array}$

13.3 Populist parties in the EP (VIII and IX legislatures) 190

13.4 Populist parties' positions (Right2Water) 193

13.5 Loyalty/rebellion of populist parties (Right2Water) 194

13.6 Populist parties' positions (car emissions) 195

13.7 Loyalty/rebellion of populist parties (car emissions) 195

13.8 Number of votes expressed by populist parties (gender equality) 196

13.9 Loyalty/rebellion of populist parties (gender equality) 196

13.10 Number of votes expressed by populist parties (immigration) 197

13.11 Loyalty/rebellion of populist parties (immigration) 197

13.12 Degree of cohesion and winning rate of European political groups 


\section{Notes on contributors}

Francesco Berti is Associate Professor of History of Political Doctrines in the Department of Political Sciences, Law and International Studies at the University of Padova, Italy. Among other subjects, he has published on nationalism and the Shoah.

Haris Dajč works in the Department of History in the Faculty of Philosophy at the University of Belgrade, Serbia. His main research interests are in the modern and contemporary history of the Balkans and the Mediterranean, the Jewish post-1945 history of former Yugoslavia and the history of postYugoslav space.

Joachim Diec is a Professor and Chair in Eurasian Studies at the Jagiellonian University in Kraków, Poland. His main fields of research are Russian political thought, conservatism, nationalism, Russia and Eurasia in international relations, world civilisations and geopolitics.

Małgorzata Maria Fijal is a participant of the Doctoral Programme in Cultural Studies in the Faculty of International and Political Studies at the Jagiellonian University in Kraków, Poland. Her main research focuses on contemporary populist movements as well as the culture and politics of contemporary Poland and Italy, with particular emphasis on identity issues.

Marcin Galent is an Assistant Professor of Sociology at the Institute of European Studies at the Jagiellonian University in Kraków, Poland. His current research focuses on the interrelationship between cultural, economic, social and political processes in the European Union.

Paolo Graziano is a Professor of Political Science at the University of Padua, Italy; Research Associate at the European Social Observatory in Brussels, Belgium; and Chercheur Associé at Sciences Po in Paris, France. He has published widely on populism.

Agnieszka Grzechynka is an Assistant Professor at the Institute of Political and Administrative Sciences at the Jesuit University Ignatianum in Kraków, 
Poland. Her main research interests focus on the Catalan independence movement and contemporary national identity dilemmas.

Tadeusz Kopyś is an Associate Professor at the Institute of European Studies at the Jagiellonian University in Kraków, Poland. He specialises in the history of Central Europe in the nineteenth and twentieth centuries, national issues and nationalism in this region. His main publications concern federation issues in Central Europe as well as the Hungarian Revolution of 1956 and Polish-Hungarian relations in the 20th century.

Ewa Kozerska is an Associate Professor of Political and Legal Doctrine at the University of Opole, Poland. Her main research interests concern Catholic social teaching, concepts of civil society and theories of European integration.

Marta Lorimer is a Postdoctoral Research Associate at the University of Exeter, UK. Her research focuses on far-right parties and on European integration. Her most recent publications analyse the far right's conception of Europe, its use of Europe as an ideological resource and political party actors' views on differentiated integration.

Elżbieta M. Mach is an Assistant Professor at the Institute of European Studies at the Jagiellonian University in Kraków, Poland. She is an expert for the Foundation for the Development of the Education System (FRSE) and the Education Audiovisual and Culture Executive Agency in the field of European educational programmes.

Zdzisław Mach is a Professor of Sociology and European Studies at the Jagiellonian University in Kraków, Poland. He has published on the Polish economy, Euroscepticism and religion in Central and Eastern Europe.

Marek Maciejewski is a Professor Emeritus of Political and Legal Doctrine at the University of Wrocław, Poland. His research interests focus on German political and legal doctrines of the 19th and 20th centuries.

Giorgia Nesti is an Associate Professor of Political Science in the Department of Political Science, Law, and International Studies at the University of Padova, Italy. She has published on the Italian Parliament and the EU.

Daniele Pasquinucci is a Professor of the History of International Relations at the University of Siena, Italy. He has published on Euroscepticism.

Gianluca Passarelli is a Professor of Political Science in the Department of Political Sciences at Sapienza University in Rome, Italy. His main research interests concern presidents of the Republic, political parties, electoral systems, elections and electoral behaviour.

Grzegorz Pożarlik is a Senior Lecturer and former Deputy Director of the Institute of European Studies at the Jagiellonian University in Kraków, Poland. His research focuses on the sociology of power, international 
security in the Post-Cold War era, civil society and the public sphere in Europe, democratic deficit and legitimacy crises in the EU, and the symbolic construction of identity in the context of the EU Eastern enlargement.

Joanna Sondel-Cedarmas is Associate Professor of Political Science at the Jagiellonian University in Kraków, Poland. Her research interests include nationalism, fascism and the far right, as well as memory of totalitarianism and authoritarianism.

Natasza Styczyńska is an Assistant Professor at the Institute of European Studies at the Jagiellonian University in Kraków, Poland. Her academic interests include transformation processes in Central and Eastern Europe, party politics, nationalism, and populism and Euroscepticism in the CEE region and the Balkans.

Przemysław Tacik is an Assistant Professor and Director of the Nomos: Centre for International Research on Law, Culture and Power at the Jagiellonian University in Kraków, Poland. His main interests include critical legal studies and contemporary philosophy.

Dario Tuorto is an Associate Professor of Sociology at the University of Bologna, Italy. He has published on the far right. 


\title{
Introduction
}

\author{
Joanna Sondel-Cedarmas and Francesco Berti
}

The revival of the phenomenon of nationalism has become a major political problem both in and for contemporary Europe. In recent years, opposition to the processes of globalisation and the programme of closer European integration, understood as a threat to the sovereignty of individual member states, has led to an intensification of Eurosceptic sentiments on the Old Continent. The results of the European parliamentary elections in 2014 and 2019, the Brexit referendum and electoral results in different European countries are all testament to the considerable growth of radical populist-nationalist and conservative-sovereignist movements and parties. The common idea that binds these groups, both in Western Europe and in Central and Eastern Europe, is a hostile attitude towards the idea of (an ever more integrated) united Europe. These parties reject not only the project of building a European federation, but also the current model of the European Union and the values underlying its attitudes. They are united by their criticism of EU policies, in particular those concerning security, emigration, multiculturalism, gender equality, the rights of minorities, as well as economic liberalism and the common currency. However, this criticism manifests itself with varying degrees of intensity, and not all parties fit the classic definition of Euroscepticism and represent its mild form of Eurorealism. ${ }^{1}$ One may essentially delineate two main branches of anti-Europeanism. The first is manifested by the rejection and radical criticism of the policies and very existence of the current EU model, seeing it as an entity dominated by a liberal and leftist system of values as well as liberal elites. This position is represented primarily by parties grouped in the group of Conservatives and Reformists in the European Parliament, which do not, in principle, question the presence of their own countries in the EU, but rather propose the creation of an alternative model for it, namely a confederation of sovereign and free states, based on intergovernmental cooperation, respecting the autonomy of individual member states and attaching great importance to their national traditions and identities. The second model is characterised by a complete negation of the EU, which sees it as an artificial, technocratic and bureaucratic entity. This attitude is represented by the Identity and Democracy group (formerly, the Europe of Nations and Freedom), which 
brings together parties which advocate leaving the EU or ending integration processes in the case of candidate countries.

This monograph attempts to bring together reflections on the organic and complex critique of the European Union, its policies and cultural and ideological character, as presented by the rather heterogeneous political constellation which is the European right wing. Its leading idea is a comparative analysis of this criticism (both as ideas, institutions and politicians), conducted through the prism of the narrative of contemporary national-populist and conservative-sovereignist parties, both at the transnational level, in Western and Central and Eastern Europe, and in terms of its intensity (whether they are Eurosceptic or Eurorealistic). This study therefore contributes to the ongoing research on a very important political phenomenon at the European level. ${ }^{2}$ The original version of the chapters contained herein was presented at an international conference entitled Europe of Nationalists. European Nationalisms From a Historical And Comparative Perspective, which took place in Krakow on 24-25 October 2019.

The volume is made up of three parts. The first concerns the attitude towards the European Union and the process of European integration of contemporary nationalisms from a comparative perspective in Western and Central and Eastern Europe. What connects this diverse spectrum of forces is the negative element of criticism - characteristic primarily of groups representing 'hard Euroscepticism' - which definitely prevails over the positive. Essentially, this precludes the construction of an alternative joint project. This is the strength, but also the limit, of this political phenomenon which has gone from strength to strength in Europe over the past two decades. Fear is another element that connects all parties which are critical of the EU, both in Western and Central and Eastern Europe, since it enables them to attract growing support by preying on the fear prevalent in European societies. As deftly demonstrated by Daniele Pasquinucci, Euroscepticism is associated in countries such as Great Britain, Italy and France, with a kind of Germanophobia, which manifests itself in a widespread fear of the emergence of a Teutonic Europe, where Germany has gained a hegemonic position primarily through economic means. The role of the fear of 'cultural others', which are perceived in terms of a threat to national identity, are perhaps key to understanding the growing importance of national-populist and sovereignist parties in Central and Eastern Europe, and this factor is carefully analysed by Zdzisław Mach. There is no doubt that in recent years the 'European threat' has been increasingly related to the migration crisis and the EU policy in this area, long branded as ineffective by the Eurosceptics. Mach, paying attention to the unique nature of Euroscepticism in the countries of the former Eastern Bloc, indicates that different historical and social conditions in the development of its nations made these Central European nationalisms take on more of an ethnic character. As a result, in this part of Europe, the fear of others (with Muslim emigrants to the fore) is felt 
particularly strongly and these societies find it extremely difficult to accept any policy connected to multiculturalism.

Using the example of the most representative political parties and movements in Western, Central and Eastern Europe, the current development of nationalism, in its various forms from national-populism to sovereignism, is analysed in the articles that make up the second part of this volume. It opens with Marek Maciejewski's chapter on the evolution of the New Right (NR) in the Federal Republic of Germany, from the 1960s to the present day. Ever since German reunification, NR has been considered one of the most important representatives of right-wing extremism in Europe, regardless of the marginal role it plays on the German political scene. Due to its nationalist and anti-liberal ideas, it is critical of the programme of European unity, and proposes a loose union of individual states on the basis of a confederation in its stead, one which clearly maintains both national and cultural identities. On the other hand, a more complex position in relation to Europe can be discerned in the activity of National Rally (RN), a French farright party whose criticism of European integration as a threat to national sovereignty has led it to become one of the most important Eurosceptic groups in Europe. In her contribution, Marta Lorimer shows the complex position of this political formation towards Europe and how it has evolved over the years. She highlights its initial support for the idea of cooperation between various European nations, based on their civilisational similarities, against the threat posed by the Soviet Union in the 1980s, through its moderate support for the creation of the European Economic Community, up until its strident opposition to the European Union from the 1990s. Giorgia Meloni's Brothers of Italy (FdI), seen as the heir to the extreme neo-fascist right in Italy, in many respects welcomes the German New Right vision of a Europe of Nations. However, the FdI represents a milder 'soft' position in its criticism of the EU, one which permits it to be considered Eurorealist. As documented by Joanna Sondel-Cedarmas, the Brothers of Italy critique of the EU focuses on its centralist-technocratic character, liberal economic policy, migrant policies and the fact that the liberal European elites support multiculturalism. In juxtaposition to these, it favours conservative ideas, economic solidarism and nationalism. The criticism of the EU is much stronger in Matteo Salvini's League programme, which makes it very close to the Eurosceptic position of National Rally and other parties belonging to the Identity and Democracy group in the European Parliament. As shown by Gianluca Passarelli and Dario Tuorto, the League is a political formation that has undergone a significant evolution over the years, from an ethnoregional grouping, focusing its support exclusively on the north of Italy, to a nationalist-sovereignty formation of a national character. Passarelli and Tuorto, analysing the evolution of the position towards the EU and the transition from the idea of l'Europe des regions to the concept of a 'Europe of nations', highlight the role of the 'European threat' as a key factor in building 
the political success of the League and taking advantage of the social fear of Europe being inundated by illegal emigrants, coupled with criticism of the ineffective European migration policy. Many of the themes covered by the League can be found in the accusations made by the English nationalist political groupings that led to Brexit. As Marcin Galent shows, their development should be analysed in terms of the unique nature of British history, which in many respects distinguishes it from continental Europe. The political history of Great Britain, with the dominant idea of the state-nation, meant that British identity stems from a multinational and multi-ethnic empire based on economic and political factors. The weakening of British identity as a result of the gradual disintegration of its empire created the requisite space for a nationalist resurgence. The revival of English nationalism, which led to a clash over national interests inside the UK and the EU, can be explained by the gradual sense of a loss of representation in national and international institutions discerned by English citizens. Agnieszka Grzechynka's text, which closes the collection of articles on Western Europe, focuses on the issues of Catalan nationalism and the role of the EU in the Catalan independence process. Catalan nationalism, which can be considered an emblematic example of cultural ethno-nationalism, one strongly rooted in history, related to the existence of a minority and understood as a bearer of a specific identity within the nation state, may be representative of other separatist movements in Europe. The article, which is a reconstruction of the main historical and political phases that led to the independence referendum in October 2017, focuses on the attitude of Community institutions towards the separatist desire of Catalonia, paying attention to the threats it holds not only for the current order in Spain, but also for determining the shape of the political affairs of the entire European continent.

In addition to the issues raised by Western Eurosceptic parties, the chapters devoted to nationalism in Central and Eastern Europe show the additional factors related to the political transformation which took place after the fall of communism and the process of European integration which had a special character in the region. Thus Małgorzata Maria Fijał, by analysing the populist political narrative on the vision of Europe and European integration, tries to present the reasons for the success of the national-populist formation of the Kuliz'15 movement, which entered the Polish political scene as a result of the parliamentary elections in October 2015. Fijał primarily connects the electoral success of this political grouping, which in many ways resembles that of other European groups, in particular the Italian Five Star Movement (M5S), with its explosive barrage of populist slogans directed against the ruling establishment and representative democracy. Also, in the case of the Polish group, the defence of the 'people' against the manipulations of the 'elites' and professional politicians is associated with a critical attitude towards Europe. However, this is not manifested in a complete rejection of the EU, but rather in the criticism of some of its policies and demands for EU reform in terms of securing greater autonomy and sovereignty for member states. Tadeusz 
Kopyś's article, which presents the evolution of Hungarian nationalism after 1989 , focuses on the analysis of the nature of two right-wing groups: the conservative Fidesz and the far-right Jobbik. In the programmes of both these parties, one can clearly discern the concept of an ethnic and cultural nation. In the case of Fidesz, a particular emphasis was placed on the role of the Christian religion in the life of the nation, which is also reflected in its characteristic vision of Europe. This it defines as a 'Christian Europe of sovereign states', whose heart should be in a Central and Eastern Europe which is seen as culturally distinct from Western Europe. The attitude of this party towards the EU can be classified, just like Law and Justice in Poland and Brothers of Italy in Italy, in terms of soft Euroscepticism. It does not see the EU as a threat to Hungary, but opposes the bureaucratic and technocratic model of the EU, its globalism and liberal democracy, and attaches greater importance to the autonomy and national sovereignty of the individual member states. Anti-European sentiment is much stronger in Jobbik's party political programme, where criticism of the EU is combined with support for closer economic cooperation between Hungary and Russia, China and Turkey. The part of the book devoted to Central and Eastern Europe ends with texts on the criticism of Europe in the narratives of nationalist groups in two countries - Serbia and Russia. The fact that neither belong to the EU means that their anti-European rhetoric takes a particularly interesting form. As Natasza Styczyńska and Haris Dajč have indicated, in the case of Serbia, the narratives of populist far-right parties are characterised by a dualism between the proWestern direction ('direction West') and the tightening of political and economic cooperation with Russia and China. Serbia, although officially an EU candidate country since 2009, is considered to be one of the most Eurosceptic countries in the territory of former Yugoslavia. Styczyńska and Dajč emphasise that the legacy of the past plays a considerable role in contemporary Serbian nationalism and is represented by anti-EU attitudes. This is particularly true of the remnants of the nationalist tendencies that developed in the last period of Yugoslavia's existence (within Serbian communism), the breakup of Yugoslavia, the issue of the NATO intervention in 1999 and, above all, the problem of the independence of Kosovo. A peculiar anti-Occidentalism is also characteristic of Russian nationalism. As Joachim Diec shows in his chapter, there is a characteristic anti-European narrative amongst a complex constellation of Russian nationalist movements. Within this, two main ideological branches can be distinguished: 1) related to 'imperial nationalism' the myth of imperial Russia and the need to rebuild Russia's global status as a superpower; and 2) representing the so-called ethnic and cultural nationalism, which is based on the ethnic concept of the Russian people, the defence of traditional Russian cultural values and the Orthodox religion, and ethnically pure Russian elements against the threat of both emigrants from the east, especially Muslims, and Western European influences.

The third part of the volume contains contributions on the attitudes of European national-populist parties towards the EU and its policies. Giorgia 
Nesti and Paolo Graziano highlight this issue through an analysis of the votes cast by representatives of populist parties in the European Parliament in 2014-2019. They emphasise the weakness of the extreme right in terms of promoting the postulates which are important to it at the European level, mainly due to its internal fragmentation. The article also addresses the problem of how to classify a multitude of contemporary populisms, noting the incompatibility of the classic right/left division and proposing to replace it with the categories of inclusivism/exclusivism. This would classify those who are radically hostile to EU politics and values as exclusivist, while moderate Eurosceptics would be termed inclusivist. The weakness of the message proclaimed by nationalist-populist groups in the European Parliament, against the background of the convincing and often triumphant rhetoric which can be seen in national contexts, also appears in the chapter by Grzegorz Pożarlik, who sees a form of (neo)ideocratic power based on a very polarised political message in nationalist rhetoric in Central Europe. This message builds its foundations on the juxtaposition of real people versus corrupt political elites and the will of the sovereign versus the rule of law. As emphasised by Pożarlik, the political narrative developed by the Fidesz party in Hungary and Law and Justice (PiS) in Poland is also an emblematic example of the anti-liberal revolution in Central and Eastern Europe. The article advances the thesis, also put forward by Zdzisław Mach, that the EU is perceived as a foreign entity, one representing a system of liberal values and left-wing ideas which are hostile to national unity, national tradition and religion. The rhetoric even stretches as far as to claim that such parties are the genuine representatives of true European values. An analysis of nationalist parties in Central Europe was also undertaken in the last two chapters, this time in light of legal and educational issues. Using the example of the politics of the Law and Justice and Fidesz parties, Przemysław Tacik highlights how a tension born of permanent opposition to liberal-democratic constitutionalism, both in the national and European arenas, has led to something akin to a 'European civil war' being fought in the field of law in Poland and in Hungary. Populist-nationalist parties have used the liberal model parasitically in order to strengthen their own executive power. For her part, Elżbieta Mach, analysing the educational reform introduced in Poland by the Law and Justice (PiS) government in 2017 , presents the issues of education in a nationalist spirit. The aforementioned reform, modelled on the ideas proclaimed by PiS, is aimed at educating citizens in the spirit of patriotic, religious values, ones which are hostile to 'the other' and closed to all external elements. Chief amongst these is multiculturalism, which is seen as particularly threatening to national identity, and the educational reform is intended to instil different (even opposing) values in the younger generation than those which underpin the EU.

Confronting the challenges of contemporary nationalism and populism is a far from easy task and in some European contexts it may even be akin to 'swimming against the flow'. It is primarily a cultural challenge that requires a highly developed system of values and identities, one which includes Christian 
ones which have been linked with European civilisation for over two thousand years. For Ewa Kozerska, Pope Francis is the most emblematic herald of this battle. His non-European cultural background allows him to critically evaluate contemporary political and cultural tendencies that predominate in the Old Continent. In the opinion of Pope Francis, Europe should stand for the basis of its cultural integration by referring to its common Greek-RomanJudeo-Christian tradition, in the spirit of openness to others, true solidarity and dialogue. Constraining this identity, fosters the emergence of extremist attitudes and perhaps will lead to the disintegration of the Old Continent.

\section{Notes}

1 Using the distinction proposed by Aleks Szczerbiak and Paul Taggart, one may divide Euroscepticism into hard and soft varieties. Alex Szczerbiak and Paul Taggart (eds), Opposing Europe? The Comparative Party Politics of Euroscepticism, 2 vol., (Oxford University Press 2008); see also Liubomir K. Topaloff, Political Parties and Euroscepticism, (Palgrave 2012); Dieter Fuchs, Raul Magni-Berton and Antoine Roger (eds), Euroscepticism. Images of Europe among Mass-Politics and Political Elites, (Barbara Budrich Publishers 2009).

2 The radical right in Europe is an extremely timely research problem. The programmes and character of these parties belong to the category of the most widely studied problems in social science, usually with a dominant Western or Eastern European perspective. The programmes and character of extreme right-wing parties have been the subject of numerous seminal analyses. Among others, one should mention the following: Michaela Köttig, Renate Bitzan and Andrea Petö, Gender and Far Right Politics in Europe, (Palgrave Macmillan 2016); Andrea Pirro, The Populist Radical Right in Central and Eastern Europe, (Routledge 2015); Michael Minkenberg (ed), Transforming the Transformation? The East European radical right in the political process, (Routledge 2015); David Art, Inside the Radical Right: The Development of Anti-Immigrant Parties in Western Europe, (Cambridge University Press 2011). 


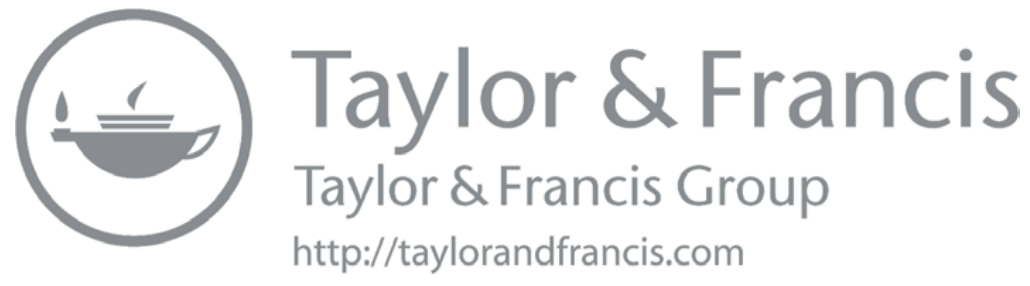




\section{Part I}

\section{Current nationalisms and the European integration process}




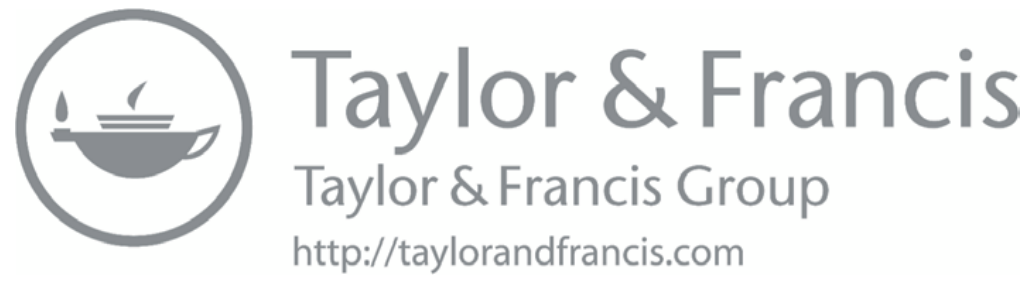




\section{Against Europe or against Germany? \\ European integration and \\ Germanophobia in France, \\ Great Britain and Italy}

Daniele Pasquinucci

\section{Introduction}

Euroscepticism is increasingly widespread throughout the European Union (EU), although it appears with differing degrees of intensity from country to country. Criticism of 'Brussels' - an inaccurate but telling eponym used to indicate the EU - is backed by a rather wide range of arguments (which are, in fact, frequently contradictory). ${ }^{1}$ In particular, one point that has an important (though of course not exclusive) place in Eurosceptic propaganda is the idea that the European Union mainly serves the interests of Germany. Nonetheless, today's Eurosceptics can hardly claim authorship of that idea. Germanophobic anti-Europeanism was actually born together with the first European Communities. The Declaration of 9 May 1950 by the French Minister for Foreign Affairs, Robert Schuman, triggered the process that would lead to the birth of the European Coal and Steel Community (ECSC). According to its critics, the fulfilment of the ECSC's lofty pro-European ideals hid the prosaic and dangerous restoration of Germany's industrial and military apparatus: it was the first step towards a 'Germanised Europe', a perspective that revived the nightmare of the Third Reich's domination over the continent.

Germany's Nazi past also poisoned the debate about the European Defence Community (EDC). The invasion of South Korea by North Korean armed forces in June 1950 seemed to confirm the worst fears about the aggressive attitude of the Communist Bloc. The war in Asia made the hypothesis of a Soviet attack on Western Europe plausible. As a result, the Americans asked their European allies to reinforce their own military capabilities, allowing the rearmament of West Germany. Predictably, France opposed this request but Paris could not simply reject Washington's plans and was forced to find an alternative solution. This took shape in the Pleven Plan - named after the then French prime minister. It involved creating a European army under the EDC, which would include a German military contingent. ${ }^{2}$ The fact that the EDC was conceived precisely in order to avoid the rearmament of West Germany did not prevent anti-Europeanists from emphasising the alleged link between European integration and German remilitarisation - with the associated risk 
of the rehabilitation of officials with a Nazi past. The propaganda proved impervious to facts.

After the 1950s, anti-Europeanism and Germanophobia continued to go hand in hand. On closer inspection, it was the latter that justified the former. Participation in the European Community (EC) actually led to objective economic advantages for all the member states; the critical issue therefore became the unequal distribution of those benefits. The structure given in the 1960s to intra-Community trade and, in the following decade, the first plans for monetary coordination would have favoured the establishment of the economic predominance of the Federal Republic (FRG) to the detriment of other member states in the Community. The fact that the EU was no longer the vehicle for the revival of Prussian militarism was only partially consoling: by means of economic integration the FRG was once again carving out a hegemonic position for itself in Europe.

It is nonetheless true that this kind of anti-Europeanism (just like its many other forms) did not manage to undermine the broad support that the EC was receiving. The EC was seen as one of the pillars of the liberal Western order capable of guaranteeing not only security and political stability but also an unprecedented level of economic prosperity. Significantly, this perception survived the uncertainty of the early 1970s, when the monetary upheavals caused by the collapse of the Bretton Woods system and the energy crisis sparked by the Arab-Israeli conflict of October 1973 led to a severe economic recession. For many years after the end of the Trente glorieuses, the European Community proved itself capable of protecting and growing the economies of its member states. Even assuming that it existed, the 'economic domination' of the FRG did not impoverish its partners in the Community. For this reason, public opinion was never seriously swayed by the idea that the EC implied the subordination of its member states to the interests of West Germany.

\section{Changing perspectives. Eurosceptic Germanophobia}

The early link between anti-Europeanism and Germanophobia and its ability to withstand the test of time - a quality considerably independent of the obvious successes of European integration - gives an important but nevertheless overlooked indication of the value of reversing the perspective used to look at the two elements of this dyad. Aversion to Germany is for the most part considered a key element of Euroscepticism. The events following the economic crises of 2008 and 2011 would seem to confirm the validity of this viewpoint. The insistence of the EU (and of Germany) on austerity, on tight budgetary policies, on fiscal discipline, has been used to propose a narrative of Europe as the 'Fourth (German) Reich': a sort of Gothic tale - as has been claimed - of which 'the disturbing return of pasts upon presents' is a fundamental part. ${ }^{3}$ It is precisely this use, or rather abuse, of the past (of History) that urges the change in perspective mentioned earlier. Euroscepticism should not be seen solely as a container of anti-German sentiment; it is, if anything, a 
vehicle useful for propagating an older and even more deeply rooted attitude. Naturally, the second perspective is not alternative but rather complementary to the first.

To analyse Eurosceptic Germanophobia (the order of terms is no accident) I have chosen three fields of inquiry: France, Italy and Great Britain. As we shall see, in these countries aversion towards Germany is a long-standing tradition. This historical legacy has contributed to making the experience of those three countries in the EC/EU partially conditioned by the sense of otherness with respect to the Federal Republic. In my opinion, this observation does not at all permit the conclusion that European integration 'was founded less on the goal of overcoming differences than on cementing them'. ${ }^{4}$ But it is nonetheless true that while the 'Europhile' attitude could go hand in hand with fear of the Federal Republic, Germanophobia has always used criticism of European integration to legitimise itself politically and culturally.

Contemporary political anti-Germanism began with the foundation of the German State. In Great Britain, however, the view of Germany fluctuated enormously, making it very difficult to see a linear development of antagonistic sentiment from 1871 to $1914 .{ }^{5}$ But after the unification of the German territories, polemic references to Prussian militarism became frequent; following the Great War of 1914-1918, they turned into actual prejudices. In Britain, denunciation of Prussia made possible a tale of two Germanies: on the one hand a state made up of sensible people such as writers, intellectuals, musicians and 'the millions of kindly men and women'; and on the other, 'the brutally aggressive [Prussian] military caste' ${ }^{6}$

In Italy, the unification of Germany provoked conflicting reactions. Appreciative and vilifying judgments coexisted in the governing elite and the intellectual milieu. Italy's entry into the First World War inevitably provoked a wave of anti-German hatred. ${ }^{7}$

With the Second World War, anti-Germanism jumped to the next level: this happened with the drawing of a line of continuity between Prussianism and Nazism. ${ }^{8}$ The entire history of Germany, from 1871 on, could be represented as a sort of preparation for the rise of Hitler. The Nazi regime was often seen as a natural inclination in the Germans, the underlying premise for the deployment of their insuppressibly aggressive attitude. A Gallup poll from January 1947 revealed that $63 \%$ of the French believed that Germany would soon return to being a belligerent state, keen to spark another war. ${ }^{9}$ It was a sort of anthropological stigma, but not surprising less than two years after the end of the war.

But recent conflicts, those that from the Deutsche Einigung onwards divided the two banks of the Rhine, only tell a part of the story. Recently, French fear of the Germans has been traced back to the division of the Carolingian empire $^{10}$ - a perhaps excessive backdating that turns Germanophobia into a kind of ontological fact, and as such extraneous to historical processes. It must be said that this theory has been discussed with interest and has received some favourable reviews. ${ }^{11}$ If, however, we abandon the hypothesis of an ancestral 
conflict, then we can consider the diplomatic crisis of 1840, the Rheinkrise that divided France and the German Confederation, to be the origin of modern French Germanophobia; ${ }^{12}$ or we could reiterate the importance of the events post-1870 in spreading that sentiment, ${ }^{13}$ which should nonetheless be kept distinct from the cultural contempt that developed between the seventeenth and eighteenth centuries, to which the Germans as individuals and not Germanywhich at the time was weak and divided - were subject. ${ }^{14}$ On the other hand, the anti-Germanic stereotypes that arose before the birth of the German State played an important role: they represented the cultural substratum on which contemporary political Germanophobia was based.

This cultural substratum survived the defeat suffered by Nazi Germany in 1945. Its main vehicle of transmission became anti-Europeanism.

\section{Misinterpreting historians}

Eurosceptic Germanophobia was, and still is, conveyed by a variety of players (politicians, intellectuals, the media). Before the Brexit referendum of June 2016, Boris Johnson declared that the EU had concretised the ambitions of Adolf Hitler, who (like Napoleon) 'tried [to unify Europe], and it ends tragically. The EU is an attempt to do this by different methods'. ${ }^{15}$ Johnson's statement caused a certain degree of scandal. Once again, however, it was not representative of anything new, especially not in Great Britain. In 1958, commenting on the birth of the Common Market, Prime Minister Harold Macmillan warned that 'Western Europe dominated in fact by Germany and used as an instrument for the revival of power through economic means (...) is really giving them on a plate what we fought two wars to prevent'. ${ }^{16}$ Thirty years later, in her famous speech at the Collège d'Europe in Bruges, Margaret Thatcher recalled the role played by her country in the freedom of the continent from Nazism: 'Had it not been for their willingness to fight and die, Europe would have been united long before now - but not in liberty, not in justice'. ${ }^{17}$

After the collapse of the Berlin Wall in November 1989, Thatcher launched a 'propaganda campaign against German reunification'. ${ }^{18}$ Obviously, the Deutsche Wiedervereinigung was a source of worry for many European governments - in particular the French. But while the French president François Mitterrand and the other EC leaders (including Chancellor Helmut Kohl) became convinced that the economic power of a reunified Germany could be contained by accelerating the process of European integration, Thatcher regarded that perspective as a chance naively offered to the FRG to establish its supremacy. After all, according to her, this objective was written into the Germans' genetic code. ${ }^{19}$ To find confirmation for her thesis, in March 1990 Thatcher put her foreign policy adviser Charles D. Powell in charge of organising a Chequers seminar on Germany. Participating in that meeting were academics and historians such as Hugh Trevor-Roper, Timothy Garton Ash, Fritz Stern, Gordon Craig, George Urban and Norman Stone. Apparently, 
they did not do much to corroborate Thatcher's prejudices about reunified Germany. If anything, they suggested that the Prime Minister 'be nice to the Germans' ${ }^{20}$ Powell drafted the seminar memorandum. How faithfully this document reflected the discussion that took place in Chequers is a controversial matter. ${ }^{21}$ It included a list of attributes that would have characterised the Germans: 'angst, aggressiveness, assertiveness, bullying, egotism, inferiority complex, sentimentality (...) a capacity for excess (...) a tendency to overestimate their own strength and capabilities'.22 When Powell's minutes were leaked to the press, this - as wrote one of the seminar's participants - obviously 'made the headlines, whether in London, Paris, or Frankfurt'. ${ }^{23}$ After all, that was what Thatcher wanted. For many readers of those headlines, the question 'Could the Germans be trusted?'24 now had an obvious answer.

In the end, the 'Chequers Affair' can be considered an example of the unscrupulousness with which politicians exploit intellectuals and their work (in this case, historians and history).

Naturally, there is no dearth of examples of scholars with a proclivity for legitimising the worst anti-German clichés without any encouragement from a political authority. According to Luciano Canfora, a distinguished scholar of the ancient world, philologist and columnist for the 'Corriere della sera' (the main Italian newspaper), the current European Union 'is an enormous German fiefdom (...) the unexpected fulfilment of the Führer's dream'. ${ }^{25}$ According to the French scholar Emmanuel Todd, the EU is a hierarchical system, with the southern countries relegated to the back, and France forced to play second fiddle, while Germany occupies the position of central power that dominates all the other member States. ${ }^{26}$

\section{Manipulating history}

One piece of information that emerges from what has been said thus far is a certain repetitiveness of the themes that feed Germanophobic and Eurosceptic views. The evoking of the Third Reich as a historical model for describing the supposed new Teutonic order is an apparently irresistible refrain for critics of the Federal Republic and the EU. This selective narrative isolates and turns a particular chapter of Germany's history into a paradigm, so that Nazism becomes a telling feature of the 'German character', unchanged by the post-war experience. The crassness of this argument should not lead to hasty conclusions. The manipulation of history to feed Germanophobic and Eurosceptic propaganda can take more subtle forms; as we shall see, the portrayal of the EU as a 'German racket designed to take over the whole of Europe ${ }^{27}$ may be indirectly fostered by the prevailing interpretation of national historical events.

From what has been said so far, it seems clear that history is the element that connects an old sentiment with one more recently formed. This happens because, for many of its critics, the European Union is an artificial, ahistorical construct. It is to history, therefore, that an appeal is made to find the 
antidotes to that artificiality - which, in the end, would be nothing but a demonstration of the irreplaceability of the nation state. The triumph over the latter through European integration, Eurosceptics maintain, is desired by the parti de l'étranger, as it has been called in France (or by the 'enemies of Italy', nemici dell'Italia, as Italian sovereigntists have started to call their proEuropean countrymen). Parti de l'étranger was a phrase used in December 1978 by Jacques Chirac in his melodramatic Cochin Appeal to make cutting remarks about the supposed 'designs' for European federalisation - proof of which he believed was to be found in the imminent direct elections to the European Parliament - and to warn that Europe must not be used to erase France and take away its individual authority and influence in the world. ${ }^{28}$

In Chirac's appeal there was an implicit callback to Charles de Gaulle's appeal to the French on 18 June 1940, to invite them to resist the occupier and not cooperate. At the end of 1978 , therefore, Chirac was claiming the right to protect France from an imaginary external threat, establishing a direct political filiation with the one who had defended the country's liberty and independence in the face of Hitler. ${ }^{29}$ The analogy was highly controversial, but had a limited impact: the Cochin Appeal was quickly forgotten.

Instead, the current anti-German hysteria ${ }^{30}$ that is affecting a broad strata of French Euroscepticism is the cause and at the same time the effect of actual historical manipulations, designed to unveil the 'scandalous' genealogy (which would have been deliberately hidden by academic historians ${ }^{31}$ ) of the post-war European project. Most recently, one proof of this tendency is the extremely controversial book by the French Europhobe Philippe de Villiers, ${ }^{32}$ J'ai tiré $^{\prime}$ sur les fils du mensonge et tout est venu.$^{33}$ This book claims to demonstrate Jean Monnet's complete subservience to the Americans, Robert Schuman's ambiguous position on Vichy France, and Walter Hallstein's Nazi sympathies at the time of the Third Reich. These portraits (harshly refuted by a group of academic historians in a letter published by Le Monde) ${ }^{34}$ are used to present European integration as a conspiracy promoted by (and for the benefit of) powers outside France, to establish Berlin's control over Europe.

In spite of their lofty ambitions, Eurosceptic Germanophobes have made history their primary victim. The abuse of the work of historians poisons the debate about the European Union. One example of this are some commentaries on an interesting book by Bernard Bruneteau, Les Collabos de l'Europe nouvelle. ${ }^{35}$ The author reconstructs the complex journey of the French (and Belgian) intellectuals who, from the 1930s onwards, supported the prioritisation of European unification, and ended up seeing the German takeover of France and the continent as a chance to make this objective a reality. It is impossible to summarise here the several, complex reasons that led those intellectuals to collaborate with the Germans to construct a Europe unified under Nazi rule. There is, however, nothing in the book to suggest that the Nazi plans to dominate Europe were a source of inspiration for the process of European integration that began in the 1950s. Nonetheless, some could not resist the temptation to use Bruneteau's research to propose an inappropriate 
analogy, namely to claim that the bases of Hitler's Europe call to mind the Single Market that came into effect in 1993 and the single currency 'to which thought was already being given in the (...) 1940s' ${ }^{36}$

Several chapters of Italian history, interpreted in specious ways, have supplied arguments to support the theory that the EU is a 'German fiefdom'. One example is the process of national unification that took place in 1861. Italian federalist historiography - which has a respectable tradition considers the Risorgimento a model for understanding the development of European integration. Scholars belonging to this school have identified an update of the activity of the moderate party led by the Count of Cavour who pursued Italian unification by way of diplomatic agreements between governments - in the inter-governmental approach to European integration. Conversely, the federalist movements striving for the foundation of the United States of Europe via the mobilisation of citizens would be the heirs of the democratic tradition of Giuseppe Mazzini, who conceived of Italian unification as a revolutionary process promoted by the people. Paradoxically, that historical analogy has more recently served to corroborate the accusation of German supremacy in the EU. For example, in France Alain Cotta did this in the context of a rather harsh judgment of the European Union and the Economic and Monetary Union. On the eve of the French referendum on the Maastricht Treaty of 20 September 1992, he wrote that the EU Treaty signalled the Germanisation of Europe. It would, he opined, bring with it the deindustrialisation of France and the EU, just the way the 'Piedmontization' (that is, the extension of Piedmont's political and administrative system to the entire peninsula) that took place in Italy after 1861 led to the deindustrialisation, impoverishment and social disintegration of southern Italy. ${ }^{37}$ Cotta spoke of the 'financial orthodoxy' adopted by Cavour, of an alliance between the latter and the foreign capital, and of the imposition of monetary unification. ${ }^{38}$ In this way, he projected a vocabulary into the past that was useful for explaining to the contemporary French population that the fate awaiting them was similar to that of the inhabitants of Southern Italy: poverty and backwardness in a Europe shaped by German interests. In that same year, the French journalist and historian Max Gallo saw the strict budgetary rules added to the EU Treaty at Berlin's request as dealing a decisive blow to Southern Italy: 'The logic of uncontrolled liberalism will cause a collapse of the South with everything that implies at a social, cultural, and judicial level'..$^{39}$

Interestingly, this interpretation of post-Maastricht European integration was welcomed by Italian Neo-Bourbon historiography. Its pseudo-scientific objective is the re-evaluation of the Kingdom of the Two Sicilies and the subsequent condemnation of national unification. According to the NeoBourbons, the building of the Italian State was a product of Masonic, antiCatholic design and would have led to the exploitation of Northern Italy to the detriment of the Mezzogiorno. In this anti-unitarian revisionism, an increasingly popular and media-driven phenomenon, it was not uncommon to find 
the main themes of anti-Europeanism, among them none other than the idea that the EU is the design of an elite class (naturally a Masonic one), aimed at de-Christianising the continent by way of the construction of a 'common space' whose historical origin lies in the hegemonic will of the Third Reich. ${ }^{40}$ In this way, the counter-narrative of national unification intersects with the counter-narrative of European integration, seen as a German conspiracy that ultimately succeeded.

However, misguided interpretations or actual manipulations of national history - or of parts of it - are not necessarily the only way through which Germanophobia and Euroscepticism are merged. The construction of the identity of a nation via a selective approach to its past may lead - sometimes involuntarily - to the same outcome. Great Britain is a case in point. The historian Oliver Daddow identified the source of the country's Euroscepticism in the modernist approach prevalent among British historians, which leads to an 'excessively reverential attitude' towards the recent past. In particular, the Second World War - a heroic epic of resistance to and eventual victory over Nazism, as media and popular culture constantly remind the British public is presented as the defining experience for the consolidation of the national conscience. Inherent in this narration is the transmission of the image of Great Britain as a great global power, linked to the United States by a 'special relationship'. Europe, however, remains the hostile 'other'. Obviously, this 'other' was often embodied by Germany, seen - both by political circles and by Eurosceptic public opinion - as a rival to be confronted rather than as a partner with whom to build a common European project. ${ }^{41}$

\section{Conclusion}

At the beginning of the 1950s, the first iteration of the European Community was disliked by those who feared the military and economic rebirth of the Federal Republic of Germany. Current Euroscepticism often employs the argument of an irrepressible German inclination to domination. The element of continuity of Eurosceptic Germanophobia is represented by the idea that European integration is the product of a plan aimed at stabilising German supremacy on the Old Continent. What Hitler had not succeeded in doing would be made possible by the founding fathers of the Community and their descendants. This misguided interpretation cannot do without history - or more precisely without a distorted use of it, a manipulation of the work of historians, and a selective approach to the past. Through these practices, the Nazi experience is de-historicised and turned into a kind of anthropological fact about the German population. This paves the way to anti-Germanic and Eurosceptic propaganda that has a specific goal and an unintended consequence. The condemnation of 'German Europe' would reveal the naivety (or the dishonesty) of those who gave up national sovereignty in the name of a common European interest: in truth, the EU would only be serving German interests. But paradoxically (and here is the unintended consequence) the 
stereotypes, simplifications, and actual falsehoods that feed Eurosceptic Germanophobia risk delegitimising - or make less credible - even serious, justified criticisms of the European Union and of the crucial role that Germany plays in EU institutions.

\section{Notes}

1 Cf Cécile Leconte, Understanding Euroscepticism, (Palgrave Macmillan 2010).

2 Cf Edward Fursdon, The European Defence Community. A History, (Macmillan 1980).

3 Catherine Macmillan, 'The Return of the Reich? A Gothic Tale of Germany and the Eurozone Crisis', (2014), 22, Journal of Contemporary European Studies, 1, 24-38, DOI:10.1080/14782804.2014.887891.

4 Almut Möller and Roderick Parkes, 'Conclusions: The Narcissism of Small Differences', in Möller and Parkes (eds), Germany as Viewed by Other EU Member States, EPIN paper, 33, June 2012, 69-72.

5 See Jan Rüger, 'Revisiting the Anglo-German Antagonism', (2011), 83, The Journal of Modern History, 3, 579-617; Richard Scully, British Images of Germany: Admiration, Antagonism \& Ambivalence, 1860-1914, (Palgrave Macmillan 2012); Thomas Weber, Our Friend 'The Enemy'. Elite Education in Britain and Germany Before World War I, (Stanford UP 2008).

6 John Ramsden, Don't Mention the War. The British and the Germans Since 1890, (Abacus 2007), 123.

7 Cf Federico Niglia, L'antigermanesimo italiano. Da Sedan a Versailles, (Le Lettere 2012).

8 Christopher Clark, Iron Kingdom: The Rise and Downfall of Prussia, 1600-1947, (Harvard University Press 2006), 672 ff.

9 Jeremy Vanke, Europeanism and European Union. Interests, Emotions and Systemic Integration in the Early European Economic Community, (Academica Press 2010), 94.

10 Georges Valance, Petite histoire de la germanophobie, (Flammarion 2013).

11 See Allemagne d'aujourd'hui, (2013), 206, 4, 236-245.

12 Renaud Meltz, 'Naissance de la germanophobie française? L'opinion publique et la crise de 1840', in Mathieu Dubois and Renaud Meltz (eds), De part et d'autre du Danube. L'Allemagne, l'Autriche et les Balkans de 1815 à nos jours. Mélanges en l'honneur du professeur Jean-Paul Bled, (Presses de l'Université Paris-Sorbonne 2015).

13 Laurent van de Wandel, “'L'Allemagne surhumaine est proprement inhumaine" ou les nouveaux visages de la germanophobie', (2013) in Allemagne d'aujourd'hui, (n 11), 233.

14 Hugues Marquis, 'Aux origines de la Germanophobie: la vision de l'Allemand en France aux XVIIe -XVIIIe siècles', (1991), 286, Revue Historique, 2.

15 www.bbc.com/news/uk-politics-eu-referendum-36295208 accessed 26 May 2020.

16 Quoted in Richard Davis, 'Euroscepticism and Opposition to British Entry into the EEC, 1955-75', (2017), 22, Revue Française de Civilisation Britannique/French Journal of British Studies, 2, 12.

17 Quoted in Oliver Daddow, Christopher Gifford and Ben Wellings, 'The battle of Bruges: Margaret Thatcher, the Foreign Office and the Unravelling of British European Policy', (2019), 1, Political Research Exchange, 17, 1-24. 
18 Benjamin Grob-Fitzgibbon, Continental Drift. Britain and Europe from the End of Empire to the Rise of Euroscepticism, (Cambridge University Press 2016), 452.

19 George R Urban, Diplomacy and Disillusion at the Court of Margaret Thatcher: an insider's view, (I B Tauris 1996), 124, 131-132; Margaret Thatcher, The Downing Street Years, (Harper Collins 1993), 790-791.

20 Ilaria Poggiolini, 'Thatcher's Double Track-Road to the End of the Cold War. The Irreconcilability of Liberalization and Preservation' in Frédéric Bozo, MariePierre Rey, N Piers Ludlow, Bernd Rother (eds), Visions of the End of the Cold War in Europe, 1945-1990, (Berghahn 2012), 275.

21 Hugo Young, This Blessed Plot. Britain and Europe from Churchill to Blair, (Macmillan 1998), 360-361.

22 Charles Powell, 'What the PM Learnt About the Germans', in Harold James and Marla Stone (eds), When the Wall Came Down: Reactions to German Unification, (Routledge 1992), 234.

23 Timothy Garton Ash, The Chequers Affair, (1990), The New York Review of Books 27 September.

24 Young, (n 21), 361.

25 Luciano Canfora, 'È l'Europa che ce lo chiede!'. (Falso!), (Laterza 2012), 39.

26 Emmanuel Todd, un intellectuel nationaliste et germanophobe à Mots Croisés in www.lejournalinternational.fr/La-montee-de-la-germanophobie-en-Europe a2187.html accessed 26 May 2020.

27 This was the definition of the Economic and Monetary Union given in the summer of 1990 by Nicholas Ridley, the Minister for Trade and Industry in the Thatcher government: cf Ramsden, (n 6), 405.

28 Benjamin Leruth and Nicholas Startin, 'Between Euro-Federalism, EuroPragmatism and Euro-Populism: the Gaullist Movement Divided over Europe', (2017), 25, Modern \& Contemporary France, 2, DOI: 10.1080/09639489. 2017.1286306.

29 Florence Haegel, 'Mémoire, héritage, filiation. Dire le gaullisme et se dire gaulliste au RPR', (1990), 40, Revue française de science politique, 875.

30 See the statement made in January 2013 by a champion of French anti-Germanism, Emmanuel Todd, during a television broadcast: 'Each time that France tries to do anything within its natural sphere of influence, the Mediterranean and Africa, Germany tries to throw a spanner in the works (...). There is a German plan to isolate France from its European sphere', www.taurillon.org/ accessed 16 July 2019.

31 See Annie Lacroix-Riz, 'Europe: l'académisme contre l'Histoire' in www.librairietropiques.fr/2019/05/europe-1-academisme-contre-1-histoire-1/6.html accessed 16 July 2019.

32 Philippe de Villiers was one of the promoters of the campaign against the Maastricht Treaty. Soon after, he founded the inflexibly sovereigntist Mouvement pour la France.

33 De Villiers's book was published by Fayard in 2019.

34 'Philippe de Villiers n'a pas le droit de falsifier l'histoire de l'UE au nom d'une idéologie', (2019), Le Monde, 27 March.

35 Bernard Bruneteau, Les Collabos de l'Europe nouvelle, (CNRS éditions 2016).

36 Frédéric Lordon, 'Avoir plus d'une idée', (2017) Le Monde diplomatique, December, www.monde-diplomatique.fr/2017/12/LORDON/58194 accessed 17 July 2019

37 Alain Cotta, Pour l'Europe contre Maastricht, (Fayard 1992), 126-128.

38 Ibid., 127. 
39 Max Gallo, L'Europe contre l'Europe. Entretiens avec Eric Fournet et Olivier Spinelli, (Éditions du Rocher 1992), 76.

40 Cf, for example, Angela Pellicciari, La gnosi al potere. Perché la storia sembra una congiura contro la verità, (Fede \& Cultura 2014). The comparison between the Piedmontisation of Italy and the Germanisation of Europe is also proposed by another exponent of the anti-Risorgimento, the Italian writer Pino Aprile (cf www. radioradicale.it/scheda/546134/presentazione-del-libro-di-marco-ascione-italosperche-siamo-arrivati-a-tanto-breve/stampa-e-regime accessed 18 July 2019).

41 Oliver J Daddow, 'Euroscepticism and History Education in Britain', (2006), 41, Government and Opposition, 66. 


\title{
2 Right-wing populism, Euroscepticism, and neo-traditionalism in Central and Eastern Europe
}

\author{
Zdzisław Mach
}

\section{Introduction}

In recent years, the rapid development of nationalist movements in Central and Eastern Europe and the electoral successes of right-wing populist parties, especially in Hungary and Poland, have provoked not only concern among liberal-minded citizens but also questions regarding the reasons for the rise of populism and the factors responsible for it. Populism, and its right-wing variant, is certainly not unique to the Central and Eastern European region, as it is increasingly present in other parts of Europe, in America and elsewhere, but a closer look at its development in post-communist Europe may throw some light not only on the peculiarities of this region but may also help to better understand how populism functions in general.

There is a great deal of theoretical discussion on populism, and it is beyond the scope of this chapter to even provide an overview or summarise it. ${ }^{1}$ Here I will concentrate on right-wing populism, as it is widely present in post-communist Europe and very significantly informs the recent political developments there. It is also closely linked to the concept of nation and to the political application of tradition, which, I will argue, is at the heart of the Central/Eastern European version of Euroscepticism. ${ }^{2}$

\section{The construction of populism and ethnic nationalism in Central and Eastern Europe}

As it is generally shared in conceptual discussions on populism, its main feature is an opposition between 'the people' and 'elites', often expressed as 'we' and 'they'. In the right-wing version of populism, 'the people' equals 'the nation'. ${ }^{3}$ So the key question here concerns the meaning given to this particular concept, which has different significance in different historical and social traditions. The region of Central and Eastern Europe, largely because of its history, tends to understand the nation as a cultural, ethnic community, rather than a political, civic one. One of the main reasons for that is the modern history of the region, which used to be divided into multi-ethnic empires. Russia, Germany/Prussia and Austria (later Austro-Hungary), covered large 
territories inhabited by many ethnic communities, some of them having their own past of statehood and sovereignty, others developing a kind of ethnic nationalism in the process of modernisation, demanding sovereignty, independence and the right to become nations in the political, not only cultural sense. Ethnic nationalism constructs a cultural community separated by symbolic boundaries from others, those who do not belong to the nation even if they may happen to be citizens of the same state and inhabitants of the same town or village. An ethnic nation is ideologically constructed and presented as a 'natural' community, rooted in its territory, language, mythologised history, religion and tradition. ${ }^{4}$ National identity is then seen not as a matter of individual choice, but as a natural, obliging identification which people inherit and which is imposed on them by tradition, as a form of social belonging and as a moral duty.

If 'the people' equals 'our nation', then who is the elite? In general, elites are corrupted in the populist view of the world, alienated from the people by their own sense of superiority. They are those who hold power in all its dimensions, and who exploit the people. Elites are also presented as morally evil, decadent, alienated from the tradition of the people. This leads to a Manichean, dualistic model of the world, divided into good and evil, moral and corrupted, the exploited and the exploiters. ${ }^{5}$

In the populist discourse, identifying 'the people' with the ethnic nation means that all those who do not belong to 'us' are stigmatised as enemies of 'the people'. Such a construction opens the door for all sorts of exclusion. But it also means that 'the elite' are those who do not belong to the nation. This principle works in two ways: those who are excluded from the nation are declared to belong to the corrupt elite. Also, if someone is classified as a member of the elite, by the same token they are excluded from the national community, at least in the sense that they do not 'truly' belong to the nation; in reality they represent foreign interests and objectively act for the benefit of the national 'others'. As it is usually the case in such ideological, mythologised constructions, it does not really matter if the people in question can be convincingly included in this or that category by any 'objective' criteria of belonging to the nation or the elite. What matters is to which side they are classified by the populist constructors of reality.

In the countries of post-communist Central and Eastern Europe, which have been struggling for generations to gain national independence and political sovereignty, and whose national identities were constructed in opposition to the dominant nations identified with empires and other ethnic communities, such an exclusive, culture-based, ethnic model of nation appeals very strongly. Cultural, ethnic others, representing foreign values, may be presented as dangerous to the traditional moral and social order, as enemies of the nation. This applies not only to other nations, especially those which are seen as historical enemies, but also to all kinds of minority groups, ethnic, religious or sexual - everyone who is accused of trying to disturb the traditional national values or even to create an alternative to them. In recent years, such images 
were created for Muslim refugees or LGBT groups. In the right-wing populist discourse, 'the people' are identified with the national community of cultural tradition and traditional values, and in general are seen as a community of people who think alike. Such a nation is a moral community, one which is endangered in its integrity by corrupt elites which betray the national values and speak and act on behalf of (and in the interests of) the globalised, cosmopolitan liberals who wish to destroy traditional nations in order to dominate, oppress and exploit them.

Cosmopolitan individuals and minority groups are not the only candidates for the status of elites in the populist discourse. This role may also be played by international, supranational institutions and organisations, such as the World Bank or International Monetary Fund. For the populists of the region of Central and Eastern Europe, the role of the elite is often given to the European Union, which is presented as liberal, cosmopolitan, trying to destroy national traditions and national sovereignty in order to create a liberal, secular Europe, deprived of values, especially collectivistic ones, such as the church and family, which nationalists/populists consider to be sacred.

\section{The crises of the EU and the rise of populist Euroscepticism}

In recent years, the EU has suffered from a series of crises which have strengthened populist movements in European societies. The financial crisis undermined trust in the EU as a stable, strong basis for the economic prosperity of the whole Community. For the new member states of Central and Eastern Europe, even though they were not particularly strongly affected by the crisis, it caused serious damage to their, perhaps somehow naïve, image of the EU as a secure haven to which they had aspired for so many years. This decrease of trust encouraged populist movements to argue that the only secure frame which might guarantee economic development and prosperity would be the nation state under a strong national government.

The second crisis, that of predominantly North African refugees, turned out to be much more significant. The prospect of receiving large number of cultural 'others', stigmatised by a negative stereotype of Muslims as enemies of Christianity and the family, who are said to resist assimilation and who are dangerous potential terrorists, generated very strong resistance not only on the side of populist political powers in Central and Eastern Europe, but also among large segments of their populations, especially those who strongly identified with ethnic nationalism. To make things worse, from the point of view of nationalists/populists, the plan to relocate refugees to all EU member states came from the liberal, cosmopolitan elites of Brussels. For many people of Central and Eastern Europe, unused to the ideas and practices of multiculturalism and already suspicious of the intentions of EU elites regarding the traditional national cultures of their region, this was a strong factor in strengthening their support of populists. In the Polish case, the refugee crisis and the panic generated among many Poles by the populist ruling party prior 
to the parliamentary elections was a decisive factor in their victory. The populist ruling party in Poland stigmatised refugees as culturally alien, dangerous terrorists who were intent on destroying Christian civilisation. The state propaganda also dehumanised the refugees by presenting them as lacking such basic features of civilised people as the determination and courage to defend their families in Syria, and carrying and spreading infectious diseases and parasites. ${ }^{6}$

\section{EU elites as the populist 'others'}

European elites are particularly dangerous from the point of view of nationalist populists, as they create alternatives to traditional national values by proposing a cosmopolitan way of life which may seem attractive to many members of society who wish to reach higher levels of consumption and are tempted by the allegedly higher status of 'civilised Europeans'. For ethnic nationalists, any attempt to build a supranational identity, including a European one, is not acceptable, and is perceived as a threat to the national identity which is believed to be the natural and ultimate good, eternal and sacred. European elites are accused of trying to create and offer a European identity, and to weaken or even destroy the national identities of the societies of the EU. This European identity is criticised by ethnic nationalists for many reasons, also on the basis that there is no such thing as one European nation, especially if the ethnic understanding of the nation is applied. A cosmopolitan, multicultural, open concept of European identity is unacceptable for those who share the view that the only 'natural' community is based on a single cultural tradition in which commonly shared values are rooted. In addition to this, the European elites are presented in the nationalist/populist discourse as promotors of values which are incompatible with the cultural tradition of 'the people', often immoral and in conflict with the religious view of the world. Here, the most prominent argument points at three elements of the liberal system of values: multiculturalism, especially openness to Muslim immigrants, the reproductive rights of women, including the right to abortion, and gender equality in general. All three elements are seen as dangerous to the cultural tradition, religion and the 'natural' order of the world.

The idea of the nation and the nation state as the natural form of social organisation, a community of people who are united by their cultural tradition and who think alike, essentially precludes the acceptance of any alternative collective identity on the same or higher level. Ethnic nationalists do not approve of any attempt to build a civic nation, on the basis of citizenship and individual choice, any concept of a multi-ethnic or multicultural nation. But they also reject any idea of supranational organisation if it is to become more than an association of sovereign, independent nation states. In such a view, the EU should not become anything more than the Common Market, a free trade zone and a platform of economic cooperation. The EU is seen by 
ethnic nationalists as a frame within which nation states fight for power and gains, and any suggestion that there is or there should exist anything like a real European community, governed by the principles of solidarity and creating its own collective identity, is seen as an empty ideology, indeed nothing more than a facade behind which real egoistic national interests are hidden. Also, the EU elites are presented as a group of cynical bureaucrats who use their position to maintain power and secure privileges. The image here is quite simple and constitutes a perfect example of a populist perspective: there are the European peoples, European nations which have their cultural identities, their traditions and their interests, and there is the EU elite, which tries to impose a new form of collective identity on them and a lot of economic and legal restrictions in order to rule for their own gains.

\section{The EU as a 'cash machine'}

In the region of post-communist Central and Eastern Europe, among the new members of the EU there is another element determining the perception of the EU which should be taken into account. The EU is primarily seen as a platform for the redistribution of resources and an opportunity for the new members to overcome the legacy of communism and to close the gap between them and the West of Europe. This legacy, and this gap, is seen differently by different groups of Central and Eastern European societies. There are those for whom accession to the EU was seen as a chance to modernise, not only in the economic sense but also to build a modern, liberal democratic society, to overcome the post-communist mentality, to create an open, multicultural civil society, one which was more individualistic, free and liberal. EU membership was a chance to accomplish all this, to install mechanisms of change, democratic and market institutions, to change the law and to educate the societies for liberal democracy and the rule of law. But for populists/nationalists, the image of the EU is very different. The Union is seen as a hub of liberal, leftist ideas and values, which are in direct opposition to those promoted by them: national unity, collectivism, national tradition, especially in such sensitive areas as family and sexual morality, as well as traditionalistic religiosity. Moreover, the EU is seen as a supranational organisation which claims to have the right to interfere in the internal affairs of sovereign member states. In those countries of Central and Eastern Europe where populist nationalists are in power (Poland and Hungary), the governments are openly Eurosceptic and engage in serious conflicts with EU institutions, mainly over core EU values, such as human rights, free media and the rule of law. At the same time, their societies tend to support their country's membership of the EU and Poland has one of the highest levels of support amongst its populace in the whole Union. ${ }^{7}$ How can this paradox be explained? What is the reason for having a Eurosceptic government of a Euro-enthusiastic society?

The explanation is to be found in the nature of this popular Euro-enthusiasm. It is mainly based on the image of the EU as a generous donor, 
disseminating European funds among poorer members and helping them to close the economic gap between them and the more developed countries. The EU is accepted, liked and supported because it gives money. But in spite of this it is still seen as an external entity, a useful 'other', whom the people of Central and Eastern Europe wish to have as a financial 'sponsor', but with whom they do not share a common identity or sense of belonging. The dominant discourse in the media presents the EU as a frame within which money is distributed for the benefit of more deserving countries and regions. But the EU remains being presented as 'external' and a foreign body. Moreover, this European money, however useful, is not seen as a common European investment in a common future. Instead it is presented as a just redistribution from the rich to the poor, as a realisation of justice, and as rightful compensation for the decades of isolation and communist domination, which is blamed for the economic underdevelopment of the Central and Eastern European region. Following this logic, it is only just that the rich now share with the poor. But what does not come with this expectation is any sense of common identity, of a community of values to which the former communist Europe now belongs. The regions of Central and Eastern Europe happily receive the money but object to any conditions being specified by the European Commission. There must be no strings attached to the donation. The poor region deserves the money but does not accept any conditions as to how the money is to be used. Any such suggestions are seen as an unjustified intrusion in the sovereignty of the recipients. ${ }^{8}$ Such an attitude reveals the lack of any sense of belonging to the EU as a community of values; the Union is just seen, as it is often said by critics of such an approach, as a cash machine. Not surprisingly, nationalists/ populists of Central and Eastern Europe, when they speak about the future of Europe, prefer it to be reduced to nothing more than the Common Market. Any attempt to link the redistribution of funds within the EU to any form of solidarity other than financial (for example, the relocation of migrants) or the fulfilment of the principles of the rule of law is rejected as an attack on the sovereign rights of member states. European identity is totally absent from this perspective; the only identity that matters is the national one, linked to the ethnic model of nation.

\section{EU values and Euroscepticism}

When it comes to values, the gap between the populists/ethnic nationalists of Central and Eastern Europe and the EU institutions and their declared axiology is tremendous. In the eyes of the populists, the EU represents everything they reject and despise: secularism, modern values with their roots in the Enlightenment (individual freedom and equality of people), gender equality, the rights of minorities. The EU openly chose and stated in treaties individualistic values as its axiological foundation, while ethnic nationalists call for the inclusion of collectivistic values such as the church, the family and the nation in the EU documents, such as the Charter of Fundamental Rights and 
the Treaty of Lisbon. In effect, populists/nationalists position themselves in a sharp cultural and ideological contrast with the EU. This is the core of the process of 'othering' the EU, presenting it as an external, alien entity which may be pragmatically useful, but which is culturally foreign.

\section{'The heart of Europe is here'}

The negative view of the EU from the point of view of Eurosceptic populists/ nationalists does not mean that Europe as such is presented in its historical representation in an equally negative way. Populist leaders of Central and Eastern Europe eagerly identify with what they consider to be 'true' European values. The core of them is Christianity, but in the larger, broader sense also the cultural traditions of European nations, presented selectively to suit the current rhetorical needs of the populist ideological leaders. In Poland and Hungary this strategy takes the form of an image of the Central and Eastern European region as the place where true European values are still cherished and preserved, in contrast to the EU where they have been forgotten and eliminated by the leftist liberal leadership of the Union. The attempts to create a permanent coalition of Visegrad countries within the EU is not only a political strategy to build a stronger position to successfully fight for national interests, but it is also an identity construction of defenders of 'true' European values and traditions against those who betrayed them and who currently constitute the EU elite.

\section{Ontological security, populism and tradition}

How can one explain this illiberal turn and the rise of populism in the region of Central /Eastern Europe, which so obviously benefitted economically from the post-1989 transformation and its subsequent accession to the EU? Among the answers, one may point to the issue of security, in its broad, ontological sense. It is important to remember that although the region certainly developed economically during the 30 years of transformation, and successfully implemented the principles and mechanisms of liberal democracy and a market economy, not everybody in these societies benefitted equally from the post-communist changes. There has been a lot of accumulated bitterness and frustration, often in spite of objective economic indicators showing progress and growing levels of affluence. In the subjective view of many citizens their situation has not been significantly improved, especially in relative terms, in comparison to others who have been more successful.

Openness, which was so often mentioned as one of the most precious achievements of the 1989 changes in post-communist Europe, also proved to be ambiguous in its cultural consequences. For many educated people it was a value they had been longing for, while there were also others who experienced a kind of culture shock and perhaps they even constituted the majority. They were exposed to new ideas, to a pluralism of values and ways of life. Their 
experience before 1989 had been that of the homogeneity of a communistdominated society, with a single, state-controlled message from the censored public media and education, a very poor choice of consumer goods, and very little pluralism in the public sphere and public space. The everyday experience of the overwhelming majority of citizens was that of the cultural, symbolic and ideological monopoly of one programme, or (as in the Polish case with the powerful Catholic church in opposition to the regime), a kind of dualism of two dominating voices. But the experience of a pluralism of choices, which would require individual free decisions and responsibility for them, was not given to most people in the region. With the 1989 changes, new ideas came through the open door to society, and pluralism also brought a need to choose and to take one's life in one's hands with all the responsibility which freedom also created.

Ontological security is a psychological but also a social condition which may be caused by a rapid and radical change, such as migration, political transformation or changes in the economic environment, all of which disturb the stability of the (natural, social and cultural) environment and deprive people of their sense of being part of a stable, meaningful world. This is a traumatic experience which causes frustration, fear and anxiety, and may lead to violence. To reduce these negative experiences, people tend to search for a chance to recreate the sense of security and stability. ${ }^{9}$ They may do so individually or collectively, through their own autonomy and independence, forwardlooking activity and entrepreneurial actions, but they may also escape behind secure boundaries of tradition, which give them simple and definite answers to all questions. There may be many reasons why some people find it difficult to restore the sense of ontological, mental security through their own actions or in partnership with others. Much seems to depend here on subjective selfperception as well as 'objective' external conditions. Old age, unemployment, low education inadequate to the shifting requirements of the labour market, a dogmatic approach to the world which may be linked to traditional religiosity - these and other factors seem likely to produce a passive reaction to the loss of security, an inability to cope with it individually and constructively, to take the future into one's own hands and to assume responsibility. Escape to tradition may be a solution. In such a situation, people may also choose to follow a strong leader, one who guarantees security and releases them from the need to make difficult decisions. Authoritarian and populist political parties take advantage of this and supply a political offer to such a demand.

A return to tradition may be a solution for those unable to cope with the sense of insecurity. Freedom may be a burden, especially since it is connected to responsibility. People who for various reasons do not feel fit to respond individually to the challenge of change, look for a remedy in the form of collective identity based on tradition. Tradition appears in this process as an escape from freedom of choice and responsibility as a source of values and norms, often legitimised by religion, it defines 'us' as a community, answers questions regarding our collective identity, and provides a sense of belonging 
to the world where everything and everybody have their place - it may also help to identify 'the others', who represent a dangerous alternative to the traditional system - for example elites, immigrants or liberals.

Tradition has become an important subject of sociological research, not only of premodern societies but also in the context of reflections on the significance of heritage and the importance of the past for present developments. Jerzy Szacki and Edward Shils ${ }^{10}$ have devoted comprehensive studies to the concept of tradition as the presence of the past in contemporary society. It became clear that tradition is a very useful and powerful instrument which may be used in attempts to construct political and ideological images and to become an essential part of collective identity. The very influential book on the invention of tradition edited by Hobsbawm and Ranger ${ }^{11}$ shows some examples of such manipulation.

Traditionalism is a kind of policy aiming at a return to tradition in order to find the roots of culture, to get rid of unwanted elements of a way of life which were borrowed from or imposed by modern society. This movement is well known in the post-colonial world, where efforts are made to replace imposed, Western values and ways with the society's own, traditional ones, suppressed and forgotten, but now revived. ${ }^{12}$ In Europe, similar processes are taking place, with tradition becoming a point of reference in search of the authenticity of culture, while the political agenda behind it is to emphasise the contrast between the original, authentic culture of 'the people' and artificial Westernisation imposed by those who had power to do so.

For clarity of concepts, it may be advisable to make a distinction here between traditionalism, which means choosing traditional culture and values rather than their modern alternatives represented by globalisation and Western-oriented modernisation, and neo-traditionalism, which refers to a conscious, often politicised, return to tradition and the rejection of modern cultural patterns and values already widely present in the society. In this context, neo-traditionalism appears in the post-communist region of Europe as a strategy to escape from the unknown, alien and dangerous new values and ways of life which come from the EU to Central and Eastern Europe. To protect themselves from this danger, the populists/nationalists/traditionalists suggest that these societies should recreate their own tradition and with it the people's healthy and moral way of life and ontological security.

Neo-traditionalism appears here as a kind of collective identity - an image of meaningful actions which refer to tradition as a source of stable and legitimate values which explain the world in simple terms, describing problems in simple categories connected with value judgements, and restore the feeling of belonging to a stable and secure community. Neo-traditionalism is also a political strategy against those who propose deeper integration with the Western world, and in particular with the EU, in the name of modernisation. Traditional values and ways of life are thus presented as a healthy alternative to liberal individualism, which restores security and dignity based on tradition and builds a more authentic collective identity rooted in tradition, 
ethnicity and sound moral principles. As such, neo-traditionalism may be a strategy chosen by populists who propose the strengthening of a healthy, culture-based nation and moving away from the decadent, liberal West, which has been chosen by the corrupt cosmopolitan elites.

\section{Notes}

1 Among the tremendous body of literature on populism, I mainly refer here to the following works: Cas Mudde, Populist Radical Right Parties in Europe, (Cambridge University Press 2007); Andrea LP Pirro, The Populist Radical Right in Central and Eastern Europe: Ideology, Impact, and Electoral Performance, (Routledge 2015); Lenka Bustikova and Petra Guasti, 'The Illiberal Turn or Swerve in Central Europe?', (2017), 5, Politics and Governance, 4, 166; Cas Mudde and Cristobal Rovira Kaltwasser, Populism: A Very Short Introduction, (Oxford University Press 2017); Rogers Brubaker, 'Why Populism?', (2017), 46, Theory and Society, 357385; Cristobal Rovira Kaltwasser, Paul Taggart, Paulina Ochoa Espejo, Pierre Ostiguy, The Oxford Handbook of Populism, (Oxford University Press 2017).

2 Radoslaw Markowski, 'Populism and Nationalism in CEE: Two of a Perfect Pair?' in Alberto Martinelli (ed), When Populism Meets Nationalism. Reflections on Parties in Power (ISPI Report 2018), 71-94; Natasza Styczyńska, 'Eurosceptic Parties in the Central and Eastern European Countries: A Comparative Case Study of Poland, Hungary and Bulgaria' in Benjamin Leruth, Nicholas Startin, Simon Usherwood (eds), The Routledge Handbook of Euroscepticism, (Routledge 2018), 139-154.

3 Cas Mudde, Populist Radical Right Parties in Europe, (Cambridge University Press 2007).

4 See Anthony D Smith, The Ethnic Origins of Nations, (Oxford Blackwell 1986); Anthony D Smith, Nationalism, (Cambridge Polity 2001).

5 Ben Stanley 'The Thin Ideology of Populism', (2008), 13, Journal of Political Ideologies, 1, 103; Cas Mudde and Cristobal Rovira Kaltwasser, Populism: A Very Short Introduction, (Oxford University Press 2017), 11-12.

6 See speech by Jarosław Kaczyński in Maków Mazowiecki, October 2015, available at https://tvn24.pl/wideo/z-anteny/komisja-europejska-wystapi-do-tsueo-zawieszenie-izby-dyscyplinarnej,1915241.html?playlist_id=31421 accessed 20 September 2020.

7 In February 2020 89\% of Poles expressed support for Poland's membership in the EU. CEBOS Komunikat z badań, (2020), 32, ISSN, 2353-5822.

8 See Zdzisław Mach (ed) Local Community, Power and European Integration, (Peter Lang 2017).

9 Zygmunt Bauman, Liquid Times: Living in an Age of Uncertainty, (Cambridge Polity 2006).

10 Jerzy Szacki, Tradycja. Przeglad Problematyki, (Poland Państwowe Wydawnictwo Naukowe 1971); Edward Shils, Tradition, (The University of Chicago Press 1981).

11 Eric Hobsbawm and Terrence Ranger (eds), The Invention of Tradition, (Cambridge University Press 1983).

12 See for example Vladimir Braginsky, The Comparative Study of Traditional Asian Literatures. From Reflective Traditionalism to Neo-traditionalism, (Routledge 2004). 


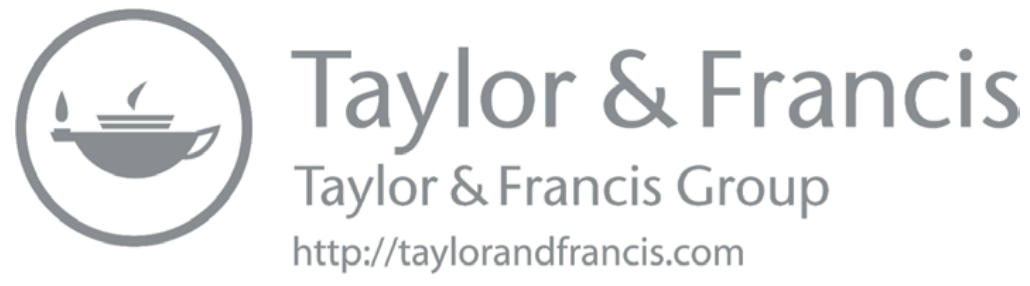




\section{Part II}

Nationalist, sovereignist and national-populist parties in Europe 


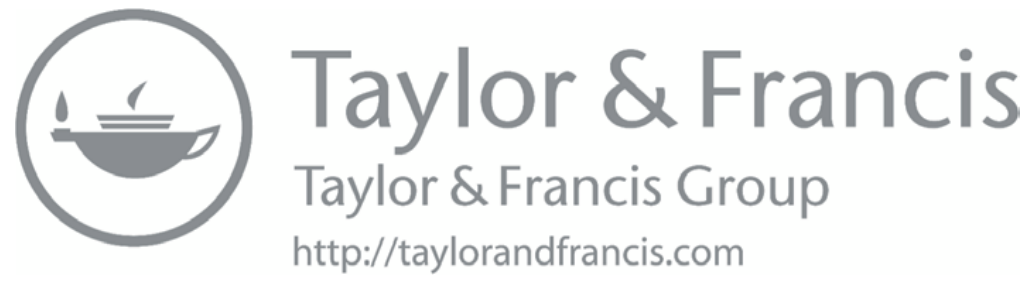




\title{
3 The nationalism of the New Right in the Federal Republic of Germany
}

\author{
Marek Maciejewski
}

\section{Introduction}

The far right has played an important role in the shaping of nationalist tendencies in some of the political environments of the Federal Republic of Germany (FRG). The authors of academic papers on this topic also use other names for this political phenomenon, chiefly the concepts of the extreme right and the radical right. ${ }^{1}$

At this point, it should be noted that the aforementioned terms do not always accurately describe the political character of the groupings that are so named as they are sometimes closer to values that are considered to be more left than right wing. Perhaps a more accurate description of the representatives of the far right would be as 'left-wing people from the right-wing', according to the terminology suggested by the German researcher Ernst-Otton Schüddekopf in $1960 .^{2}$ My doubts regarding the validity of using those terms seem to be confirmed by the political concepts of one of the main far-right trends in the FRG, namely the New Right (Neue Rechte). The ideology, organisation and work of this far-right faction is discussed in this chapter. In this introduction, one should also state that the New Right (NR) is different from the 'old', conservative and even liberal right represented in the FRG, at least partially, by the CDU, CSU and FDP, due to its nationalism, anti-democratism, as well as populism and elements of a left-wing world view. One of the most important distinctive features of this far-right trend - using the name NR with some reservations - is undoubtedly nationalism, usually connected with the adjective 'new', since it is different at some points from the pre-1945 German nationalism. ${ }^{3}$ The new nationalism of the New Right is not as dangerous, primitive and aggressive as the nationalism of the Weimar Republic, and the Third Reich in particular, which does not mean that it poses no danger to the constitutional order of the FRG, and even for other European countries, including Poland. 


\section{The genesis of the phenomenon}

In terms of the origins of the NR, it began to shape itself shortly after the Second World War, and was a significant and influential political movement at the end of the 1960s and in the 1970s. It was connected, among others, with the effects of the revolt of young people in the West and the crisis of capitalism at that time, which turned out to be also inspiring, or even more inspiring, for the development of the New Left. At the end of that century, and at the beginning of the 21st, the NR experienced a structural and intellectual crisis after its time of flourishing. The NR has been shaped mostly in the RFG and France, but it has also developed - to a lesser extent - in the UK and the USA, and for several years it has manifested some political activity in Russia, where, nota bene, the theory of the former 'crown jurist' of the Third Reich, Carl Schmitt, has experienced something of a renaissance. In all those countries, but mostly in Germany and France, the New Right bases its concepts and activity primarily on the pre-war nationalist and anti-democratic doctrine of 'conservative revolution' (Konservative Revolution) in the Weimar Republic, adapted to its current propaganda goals. After the Second World War, the NR also brought its own political and social concepts to the extreme right ideology, which were more appropriate to contemporary times. However, according to the FRG scientist, Hans Gerd-Jaschke, the concepts of the German NR are not original, since they are mostly based on the ideas of the French new right representatives (A. de Benoist et al.). ${ }^{4}$ However, it does not seem that the influence is only one-sided in this matter.

In Germany, reunited since 1990, the NR is one of the four elements of right-wing extremism - beside its national-democratic direction (Nationaldemokratische Partei Deutschlands - NPD), national-liberal parties (Deutsche Volksunion mostly, but also die Republikaner) and neoNazi groups (which are small and ephemeral - recently, mostly the so-called Kameradschaften). The NR dominates the remaining far-right trends in the FRG with its political programme, although not always with the originality of its views, giving ready ideological solutions to the related groups that they eagerly use in their propaganda. However, it is usually weaker when it comes to organisation, since it mostly takes the form of associations, discussion clubs or individual publishing houses rather than actual political groups, let alone political parties. Just like pre-war revolutionary conservatism, the NR is above all an intellectual trend. Its origins in Germany can be traced back to the polarisation of the positions of the right-wing forces in Germany at the turn of the 1940s and 1950s regarding the assessment of Nazism in the history of the country. ${ }^{5}$ It was then that the division into supporters of the 'old' nationalism, i.e. the former right wing which drew on the legacy of National Socialism and looked for its inspiration in the model between the NSDAP and the right-wing nationalist Volkspartei Deutschnationale at the end of the Weimar Republic, and the advocates of a 'new' nationalism, free of this historical burden, took place. Although the NR tried to cut itself off 
from the Nazi past, it did not fiercely condemn everything Nazi, seeing some positive aspects in it such as the elimination of unemployment, the development of industry, the state's care for social issues, etc. According to Uwe Backes and Eckhard Jasse, this new nationalism - as a distinguishing feature of the earlier revolutionary conservatism - became the origin of the NR movement. This nationalism began after the Second World War, in 1949, when Anton Hausleiter founded the Deutsche Gemeinschaft (DG), whose goal was to transform Germany into a 'neutral central block between East and West'. ${ }^{6}$ DG developed the concept of a 'third way', which meant a call for Germany to oppose the hegemony of two superpowers in Europe: the USA and the USSR.

In order to consolidate the new right, in 1965, Hausleiter established an organisation called Aktionsgemeinschaft Unabhängiger Deutscher with around 2,500 members. In the early 1970s, it was transformed into a 'life protection party', referring to another element of the NR worldview, namely its attachment to the principles of ecology that were formed at that time. The assumptions of this organisation were based on the anti-civilisation, catastrophic worldview of the philosopher Oswald Spengler, who was counted among the pre-war revolutionary conservatives. Among the groups that formed the foundations of the NR in Germany it is still necessary to mention the Deutsch-Soziale Union (DSU) founded in 1956 by the former opponent of Adolf Hitler, Otto Strasser, as a 'synthesis of freedom and justice'. ${ }^{7}$

Like other right-wing organisations, this group turned out to be ephemeral, and in 1962 it transformed itself into the Unabhängige Arbeiter-Partei (UAP), which, without much social resonance, proclaimed the concept of a solidarity-based German national community (Volksgemeinschaft). It was no stranger to the reformist views of the 19th century socialist Ferdinand Lassalle. The DSU and the UAP constituted the link preceding the shaping process of the proper NR in Germany.

On the way to the formation of this right-wing extremism, other organisations appeared in the 1950s. One of them was Bund Nationaler Studenten (1956), which ran a both anti-communist and anti-capitalist magazine Nation Europa addressed to young readers, who were no longer entangled in the Nazi past of their nation. In the magazine, young neoright representatives (including Peter Dehoust, Martin Mussgnug and Peter Stöckicht) popularised the nationalist views of the 'father' of the European NR, Julius Evola, the French extreme right-wing theorist Maurice Bardèche or the leader of British fascists, Oswald Mosley, ${ }^{8}$ among others.

The talented columnist Henning Eichberg started to cooperate with the magazine; unlike others on the neo-right, he was generally sceptical about the usefulness of the ideology of pre-war revolutionary conservatism in the shaping of the NR. At the beginning of the 1960s, the FRG intensified its efforts to broaden its organisational and journalistic neo-right activity. It is worth noting that even before the youth protests of 1968 , the following 
magazines were created: Missus by Hans-Michael Fiedler, 'Fragmente' by Gert Waldmann and Junges Forum by Johann Penz. Their aim was to oppose the old right wing - CDU and CSU - as well as the critique of parliamentary democracy in the FRG through 'spiritual regeneration combined with moral renewal of our nation and homeland shamefully split in two by the AmericanSoviet conspiracy'. Like many other political forces in West Germany, the NR never came to terms with the consequences of the military defeat of the Reich in 1945. This is also exemplified by the 1964 programme appeal of the farright organisation Initiative der Jugend, whose main slogan was: 'German neutrality - unity and freedom for the nation'. The criticism of the Yalta-Potsdam order expressed in these words was used by right-wing extremists in the early 1970s in their 'resistance action' (Aktion Widerstand) against the agreements aiming at normalising the FRG relations with its eastern neighbours. The action of resistance against these treaties, however, was not directed against the Polish or Czech nations, but against the 'imperialism of the USA and the USSR'. ${ }^{9}$ According to Penz, both of these countries were 'the perpetrators of a great tragedy of all Europe' after the Second World War, and not just 'the humiliation of German dignity and national pride' (1972). At the turn of the 1960s and 1970s, some NR groups (including Aussenparlamentische Mitarbeit and Volkssozialistische Bewegung Deutschlands) even called for the solidarity and cooperation of all oppressed European nations.

\section{Developments from the end of the 1960s}

The breakthrough moment in the formation of the NR in Germany was the aforementioned student revolt of 1968, which coincided with the social-liberal coalition coming to power. The increase of political activity of the socalled new nationalists competing for political influence with the New Left, inspired, among others, by Herbert Marcuse, was manifested by the spontaneous establishment of 'base groups' (Basisgruppen) at universities with 15-20 members each (including Republikanischer Studentenbund in Bochum and the Symenenko Club in Munich). An important event in the development of the NR was also constituted by the political arguments in the leadership of the NPD after the Bundestag elections of 1969. As a result of those disputes, the party collapsed in 1972 and Siegfried Pöhlmann founded the organisation called Aktion Neue Rechte (ANR) with around 450 members. ${ }^{10}$ Its programme, referring to the 'nationalism is progress' slogan that was then popular in radical right-wing circles, can be described as national-revolutionary, and therefore in fact closer to the left than to the right. ANR was in favour of a 'German revolution', 'solidarity of the national community' and 'democracy of freedom'. Like many other NR groups, this organisation turned out to be ephemeral. In 1974, in Wurzburg, the Nationalrevolutionäre Aufbauorganisation (NRAO) emerged and it was later joined by another small group named Sache des Volkes. A pre-war revolutionary conservative, Ernst Niekisch, known for promoting the idea of the German-Soviet alliance, 
became their ideological patron. However, some of the NRAO activists did not mind proclaiming slogans postulating a completely different alliance, namely the cooperation of European national-revolutionary forces with communist China, aimed at ending the world hegemony of the USSR and the USA. Thomas Schulze and Udo Reinhardt, the editors of the neo-right Freiheit magazine, often spoke out against this hegemony in the 1970s and 1980s. It is worth mentioning that the national revolutionary circles of the NR liked and appreciated the establishment and activity of the NSZZ 'Solidarnośc' (Solidarity). In connection with the 1980 and the subsequent banning of the independent labour movement in communist Poland, the slogan 'Better to die standing than to live on one's knees' appeared in the publications of this NR trend in FRG.

Regarding the further development of the NR with a national revolutionary ideology, the establishment of the Solidaristische Volksbewegung in Hamburg in 1974, which a few years later became the Bund Deutscher Solidaristen, should also be mentioned. From the beginning of the 1980s, the quarterly Aufbruch began to be considered the leading voice of this part of the neo-right. Its anti-liberal, ecological, populist and political profile was supposed to attract the supporters of the so-called third way of German development to the NR. The third way was based on two main assumptions: new nationalism and socialism with nationalist elements. ${ }^{11}$ Although those on the national-revolutionary neo-right criticised the Soviet Union, the editors of Aufbruch did so only in moderation (also with regard to the Soviet Union's policy towards Polish affairs after the creation of the NSZZ 'Solidarność'), speaking more negatively about the USA. Undoubtedly, this branch of the NR was characterised more by anti-capitalism than anti-communism. Also, in the 21st century, the national-revolutionary representatives of the extreme right in Germany - although the Soviet Union no longer exists - still use the political rhetoric from decades ago. In recent years, they have even gained some popularity because of the anti-Americanism spreading in Germany, especially in connection with the US war against Saddam Hussein's regime in Iraq in 2003 and the subsequent international armed conflicts in the world (Afghanistan, Syria and others).

However, another neo-right magazine published since 1970 by Caspar Schrenck-Notzing and Armin Mohler in Munich, Criticòn, cannot be described as clearly anti-capitalist. It became a theoretical guiding light, especially for members who were less radical the national revolutionaries of the NR in terms of social issues and whose goal was to give up populist slogans and build an elite model of power and society, among others. From the outset, Criticòn also proclaimed the idea of bringing the West German neo-right closer to its French counterpart, Nouvelle Droite. ${ }^{12}$ Other West German neo-right activists, including the Nationalistische Front founded in 1985 under the leadership of Meinolf Schönborn, also cooperated with the French NR and similar political forces in other countries (including Belgium and Spain). After the organisation was banned in 1992, it was transformed 
into the Sozialrevolutionäre Arbeiterpartei, continuing some elements of the 1979-created Freiheitliche Deutsche Arbeiterpartei (FAP) propaganda, including the 1920 Nazi party's programme 'The common good before selfgood' (Gemeinnutz vor Eigennutz). The views of FAP activists against economic liberalism principles were sometimes combined with anti-Semitic concepts. The editors of the aforementioned magazine 'Nation Europa' spoke in the same vein. More recently, the magazine has started to focus on the currently fashionable and propagandistically exploited issues of environmental protection.

\section{Ideological and propaganda assumptions}

Returning to the theoretical assumptions of Criticon, the concepts of the pre-war revolutionary conservative current called 'Young Conservatism', represented by Arthur Moeller van den Bruck, Edgar J. Jung, Carl Schmitt and Oswald Spengler, turned out to be popular in the circles associated with this magazine. Mohler was the epigone of this direction. Other publishers (Sinus Verlag and Herder Verlag) and associations (Verein zur Förderung Konservativer Publizistik or Verein zur Förderung Kultur- und Sozialwissenschaftlicher Publizistik) cultivating the achievements of the 'conservative revolution' further succoured Criticòn. At that time, Herder's publishing house in particular made a significant contribution to the promotion of the neo-right worldview, which, among other things, thanks to the conservative German author Gerd-Klaus Kaltenbrunner, focused on the issues of the German national community considered in terms of 'liberating nationalism' (Befreiungsnationalismus). ${ }^{13}$ As early as the 1970s, the aspiration to present more recent German history in such a way as to 'overcome the past' burdened with the crimes of the Nazi period became apparent in the texts published by this publishing house. The efforts of a part of the NR to re-evaluate the assessments of this stage of the history of its own state and nation somehow influenced the content of the dispute (the so-called Historikerstreit) on the uniqueness of Nazi totalitarianism, heated in the mid-1980s among West German scholars and publicists. From the neo-right circles of researchers, several scientists (including the political scientist Hans J. Arndt, historian Hellmut Diwald, sociologist Robert Hepp, philosopher Günther Rohmoser, political scientist Bernard Willms) joined the fierce discussion on this issue and tried to undermine the exceptional nature of Nazi crimes. ${ }^{14}$

The national question turned out to be such an inspiring and demanded topic of both scientific and political discussions, even before 'Historikersreit', that in 1979, NR ideologists decided to issue in Kolbenz a new nationalist magazine called Wir selbst. A year later, a new magazine named Deutschland in Geschichte und Gegenwart, published by Pierre Krebs connected with Grebert Verlag, joined the trend of promoting a new look at the history of the Third Reich. In the 1980s, Krebs was also the initiator of other neo-right editorial 
and organisational enterprises. One of his political activities was the association Thule-Seminar, created in 1980 who proclaimed the slogan 'Germany for Germans' (Deutschland den Deutschen). In 1987, the same nationalistic and xenophobic ideological assumptions were the basis for the 1986 magazine Elemente, based on the French neo-right periodical of the same name. In 1987, Krebs included the political credo of the then NR in Germany, namely freeing Europe from the domination of the USA and the USSR, restoring the national and cultural identity of this continent, developing its cooperation with the countries of the so-called Third World and working out a third way for the social development of Europe..$^{15}$ Most of these slogans have not lost their relevance in the new political situation on our continent after the break-up of the Soviet bloc in the early 1990s. Some of them became even more meaningful than before - due to the growing nationalistic and separatist tendencies in Central and Eastern Europe at the end of the 20th century, a growing fear of proletarianisation, the ineffectiveness of democratic ways of governing, etc.

\section{The influence of German reunification}

The NR activity in the FRG, as well as other political phenomena in Germany - were undoubtedly influenced by the reunification of Germany in 1990. As already mentioned, the fact of reunification did not cause a significant growth in the importance of the neo-right, although an increase in its political activity was visible in the first years after reunification. It was mostly their quest for power that ideologically inspired the neo-Nazis, who, at that time, became a severe threat to public order, through their violent behaviour towards foreigners, among others. They had not ceased being a threat - although perhaps to a lesser extent - by the turn of the 20th and 21 st centuries. In terms of the NR, at the beginning of the 1990s, it gained unexpected support from a section of the members of CDU - the governing party. In 1992, 192 members of CDU founded the Christlich-Konservatives Deutschland-Forum (CKDF), which followed the example of pre-war revolutionary conservatism. The formation cooperated with the neo-right magazine named Junge Freiheit. ${ }^{16}$ The periodical propagated, among others, the concepts of 'German Socialism' created by Werner Sombart in the first half of the 20th century, which called for the mobilisation of the German nation against some external danger, 'the ideas of 1914' by Johann Plenge and even the views on the advantages of the 'dictatorship of the sabre' developed by the 19th century Spanish conservative Juan Donoso Cortes. ${ }^{17}$

One of the most active propagators of the NR at that time was Günter Maschke - an admirer of Moeller van den Bruck, Spengler, Schmitt and several other revolutionary conservatives. Thanks to his political contacts, the CKDF managed to create a couple of small discussion clubs (including Potsdamer Kreis, Karlshorster Kreis, Petersberger Kreis) under the catchy slogan 'Everything for Germany'. Most of them, however, did not survive 
the turn of the 20th and 21st centuries. Although these small NR associations were replaced by new organisational or journalistic formations (e.g. 'Neue Alternative für Deutschland', 'Unsere Zukunft' or 'Neukonservative Freiheitsbewegung'), they no longer play such an opinion-forming and political role as they did years ago or have even become inactive. Although the period of NR's greatest development in Germany has passed, its philosophical and ideological assumptions have not changed. They are still attractive to the part of German society (especially its young generation) which supports nationalist and even racist and anti-democratic ideas. As early as 1998, far right-wing ideas - coloured, after all, by socialist elements - were accepted by $15 \%$ of young people in the West and as many as $23 \%$ of young people in the East of Germany (the former GDR).$^{18}$ At that time, more than half of young German citizens also declared their dissatisfaction with both the political and social systems of their country. At the beginning of this century, little has changed in this respect, especially in connection with the considerable and largely uncontrolled influx of refugees from Arab countries and Africa into Germany from 2015. The NR perceives this process as a serious threat to Germany's national identity.

\section{A word on its doctrinal foundations}

Both the doctrinal and propaganda aspects of the NR in Germany after the Second World War comprise different philosophical, political and social concepts. Many of them have been either directly or indirectly borrowed from other idea creators since the early Modern period up until the 20th century. Apart from the ideas of pre-war revolutionary conservatives, who were particularly appreciated by the NR, and the aforementioned Julius Evola, the NR was inspired by the concepts of Niccolo Machiavelli, the immoralist and nihilist Friedrich Nietzsche, syndicalist Georgesa Sorel, the anti-democrats Josè Ortega y Gasset and Charles Maurras, zoologists Konrad Lorenz (Nobel Prize laureate) and Irenäus Eibl-Eibesfeldt, psychologist Gustave le Bon and the historians of religion Georges Dumèzil, Mircea Eliade and Louis Rougier. The concepts were often juxtaposed quite accidentally. The neo-right theoreticians sometimes also draw on the achievements of left-wing thought, especially the views of the cultural communist Antonio Gramsci and JeanPaul Sartre, who was himself charmed by Marxism. In ideological terms, the NR in Germany shows a certain similarity to the so-called technocratic conservatism which had been developing in the country even before the reunification of Germany and the GDR, represented by Ernst Forsthoff, Hans Freyer and Arnold Gehlen, among others. ${ }^{19}$ However, in general, the NR does not accept the admiration of these ideologues for contemporary technical achievements, but appreciates instead the nationalist premises of their views on society and the state. Although the NR appeals to the indicated ideological legacy, partly building its doctrine on it, it rejects the pessimistic assumption that all values (truth, absolute, sense of life, etc.) are relative and do not exist 
in reality - apart from politics, natural social hierarchy and some elements of tradition.

The elements forming the core of neo-right thought include a conglomerate of various slogans and postulates that do not always form a cohesive whole. They all serve a single propaganda purpose: to convince the broadest possible circles of German society which are dissatisfied with the policy of the FRG authorities for various reasons, of the legitimacy of the NR and to criticise those in power from the position of right-wing, anti-democratic radicalism. Therefore, it is unsurprising that in the ideological arsenal of the neo-right one can find, for example, a view on the decadence of Western civilisation in the 20th century, modelled on the aforementioned theory of Spengler. As in revolutionary conservatism, it corresponds to a strongly resounding anti-liberalism, slightly less exposed anti-communism, or to the preferred anti-egalitarianism. A new, i.e. all-German, nationalism 'for all' comes to the fore as a basic trigger for social and political life, and sometimes also racism with antiSemitic overtones or hostility to so-called aliens - mainly Islamic migrants. In order to avoid any overt references to Nazi propaganda, the above-mentioned components of NR thought are usually hidden under the modern, 'sciencesounding' terms of bio-humanism and ethnopluralism. Added to this is an only slightly camouflaged and mystified neo-paganism (belief in a Germanic religion and myths, negation of Christianity, etc.). The neo-right is also characterised by the belief that politics reigns supreme over the economy, culture and all other areas of public life. As for the first of the listed elements contained in this ideological catalogue, i.e. the negation of Western values, it should be noted that it stems from the NR's fundamental criticism of the philosophy of the Enlightenment and the French Revolution at the turn of the 18th and 19th centuries. Just like the representatives of the NR in France, those on the German neo-right (e.g. Henning Eichberg and Gerd Waldmann), confront a liberal revolution with a revolution with national characteristics, i.e. pit 'a revolution against a revolution'. They accuse the 'progressive revolution' of creating human and civil rights that contradict the natural diversity of people and are based on -according to those on the neo-right - a false principle of equality and identicality. They perceive the spread of the concept of these rights as a manifestation of 'ideology for pensioners', which should be replaced by the assumptions of a more modern form of 19th-century social Darwinism, i.e. an aetiology assuming similarity of human and animal behaviour. ${ }^{20}$ According to Waldmann, it is enough to study zoopsychology to understand the real motives of human behaviourism: the struggle for species survival, for food and for own territory. They give rise to the natural need to conduct wars as, among others, 'a regulator of excess population in the world'.

This concept of human beings, also presented by the NR outside of Germany, is based on racial premises, although they are not exposed as clearly as in Nazi or neo-Nazi ideology. However, those on the neo-right in Germany (e.g. Waldmann) consider the consolidation of polygamous 
divisions, especially between the white and black races, to be a necessary condition for proper historical development. Therefore, the concepts of proxemics are popular among the NR theorists, i.e. the science of the relationship between a specific culture and the area and time of its development. ${ }^{21}$ Using the term 'ethnopluralism' to divide human races into better and worse ones, representatives of the neo-right eagerly seek confirmation of the validity of this thesis in the results of the IQ test commonly used in the West after the Second World War. It replaced the anthropological and eugenic studies of races carried out previously, especially in the Third Reich. For understandable reasons, the NR attributes the highest intelligence quotient to the members of its nations: Germans, French and others - although not all of them. Neoright representatives consider Jews to be a negation of the high intelligence of Germans or other Western nations less frequently than 'classic' Nazi and neo-Nazi racists, although the NR doctrine is by no means free from antiSemitic sentiment. Jews are blamed, among others, for the development of the capitalist relations it criticises. ${ }^{22}$ The NR's postulate that the state should conduct a proper 'biopolitics' towards terminally ill persons, criminals and the socalled anti-social elements does have a racist background. For this purpose, even the use of euthanasia is not ruled out and, in relation to particularly valuable people, the use of the latest achievements of embryology (cloning of human genes). All this is intended to achieve one goal - to breed a new type of Nietzschean 'superhuman': a healthy, strong, and intelligent German or Frenchman, who would belong to the elite of their nation as a representative of the so-called meritocracy. ${ }^{23}$ They should also be able to free themselves from the 'slave principles of Jewish-Christian religion and morality' (Waldmann) that hinder their development. In this area, the NR is looking for models to follow in the pagan faith and the culture of ancient Greece and Rome.

As far as social matters are concerned, it advocates increasing state interventionism in an economy with modified capitalist features (e.g. by increasing the share of employees in the management of production and service plants), without demanding - with few exceptions - the abolition of private property. The future social system is imagined as a corporate system functioning on the principle of solidarity between employers and employees united by common national goals. The NR is not alien to the views of some left-wing thinkers in this field: the aforementioned reformer Ferdinand Lassalle, syndicalist Georges Sorel and even anarcho-individualist Pierre Proudhon. Following the example of pre-war revolutionary conservatives (especially Ernst Jünger), it encourages the 'total mobilisation' of the German people in order to bring about continuous improvement in their material situation. In its social views, it also stresses the need to 'spiritualise' the economy by eliminating the 'merchant spirit' from public life. However, it should be noted that for the NR, social relations - unlike national issues - have never constituted a fundamental doctrinal problem. In any case, they have not received a comprehensive formulation in the confines of this ideology. 
The NR in the FRG focuses more on the issues of the political system. From its inception to the present day, it has been an advocate of authoritarian rule, although it does not criticise parliamentary democracy as fiercely as its precursors - the revolutionary conservatives, not to mention the Nazis. A model for the neo-right in this field is the doctrine and practice of Bonapartism, i.e. a plebiscite dictatorship that combines elements of the actually limited power of a charismatic leader with elements of direct democracy, sometimes referred to in NR ideology as organic democracy. As I have already mentioned, in matters of the political system, it willingly refers to Carl Schmitt's concept, and especially to his theory of sovereignty. Let me recall here that, according to this lawyer, the actual, and not only constitutional, sovereign is the one who 'decides on the state of emergency'. ${ }^{24}$ Schmitt's admirer, the aforementioned Mohler, modified this view in 1988. In his opinion, at the end of the 20th century, which was characterised by conflicts on a global scale, the real sovereign is the one who decides on the use of atomic weapons. ${ }^{25}$ As for the political doctrine of the NR, due to its nationalistic and anti-liberal assumptions, it is critical of the issue of European unity. Instead of fully integrating the continent, it advocates loose federal ties between individual states - with a clear preservation of the national and cultural identity and distinctiveness of European countries. For this reason, it was negative towards the Maastricht Treaty (1992), perceiving the European Union as a new kind of bureaucratic and cosmopolitan hegemony, and even a totalitarianism of sorts on our continent. It is no wonder that the NR, also outside of Germany, is critical of the process of enlarging the Union to include new members. What is more, it opposes such 'irresponsible actions' which will result in 'our continent ceasing to constitute an intrinsic value' and becoming 'a mass of atomised people, unrelated to each other in mutual relations - except for exuberant consumerism and hedonism' (Waldmann).

In terms of this issue, as well as a number of other political or social matters, it is driven primarily by the criterion of German national interest that is referred to constantly in its political rhetoric. Its far-reaching nationalist goals were already revealed in the magazine entitled Nation Europa, which was established early in the second half of the 20th century by former members of the Nazi SS. They referred to the ideas of Imperium Germanicum or Imperium Teutonicum, which were close to those of the pre-war German revolutionary conservatives, and even to the concepts of the so-called Central Europe (Mitteleuropa) by Friedrich Naumann. All these political ideas were integrated by one essential belief - that it was necessary to ensure Germany a leading, even hegemonic role on the Old Continent. This is the only way for the NR to recognise the implementation of the idea of a common Europe, although in general it does not explicitly articulate its imperialist goals and is officially critical of it. Instead, it tries to emphasise Germany as the cornerstone of the current economic power of the European Union. It seems somewhat obvious what lies behind such a move. Since the European Union is 
already functioning, let Germany have the greatest influence on this organisational structure, and even let Germany determine - primarily in its own interest - the methods of its operation and directions of further development.

\section{Conclusions}

It should be restated that the new nationalism, as a keystone of the ideology and propaganda of the NR, makes this trend of the extreme right attractive to those Germans who critically - from a radical right-wing position - refer to the political, social and ethical values underlying the German system. However, the NR itself does not effectively undermine the stability of the constitutional system, nor do neo-Nazis. One cannot expect a fundamental transformation of the political scene in contemporary Germany any time soon.

However, the growing popularity of the extreme right should not be underestimated in this and other European countries. According to more recent sociological studies, people of low and medium material status (e.g. as many as $50 \%$ of workers in Austria and 30\% in the UK) are increasingly inclined to vote for populist and demagogic extremist right-wing parties in European parliamentary elections. This fact alone may raise certain concerns, although it is not yet a cause for alarm. In any case, there is no doubt that our continent is becoming increasingly 'brown', as Anna Wolff-Powęska noticed already in 2001. ${ }^{26}$ Throughout the two first decades of the 21st century, organisations of the radical right in France (Marine Le Pen's National Rally formerly known as the National Front), Belgium (Marco Santi's National Democratie and Frank Vanhecke's Vlaams Bloc, which was established in 2004), Austria (the late Jörg Haider's Freedom Party of Austria), Denmark (Kristian Thulesen Dahl's Danish People's Party), Portugal (André Ventura's Chega), Spain (Santiago Abascal's Vox), Switzerland (Alberta Rösti's Swiss People's Party), Italy (Matteo Salvini's League, formerly known as the Northern League), the United Kingdom (Adam Walker's British National Party), or in Greece (Nikolaos Michaloliakos' Golden Dawn) are becoming increasingly active. The extreme right is also becoming more vocal - and even more so than in the West - in Central and Eastern Europe, including Poland and Russia. All the groups referred to by this term preach similar propaganda slogans, which, according to the Austrian researcher of the extreme right Anton Pelinka, express 'nostalgia for socialism', i.e. the desire to introduce socialism with national characteristics combined with xenophobia. ${ }^{27}$ It is difficult to predict how this right wing is going to develop in the future - especially in the face of the European Union's organisational weakness and the massive influx of Asian and African refugees to our continent. It seems that the popularity of the NR is unlikely to decline, and may even increase and the political success of the Alternative for Germany seems symptomatic in this regard. While not explicitly part of the NR, it shows certain ideological similarities with the populist radical right. There is no doubt that the nationalism exhibited by the NR, with the added adjective 'new', will come to determine 
and define the propaganda face of the extreme right in the FRG for a long time to come.

\section{Notes}

1 More recent literature - cf Alice Brauner-Orthen, Die Neue Rechte in Deutschland. Antidemokratische und rassistische Tendenzen, (Leske and Budrich 2001); Margarete and Siegfried Jäger, Gefährliche Erbschaften. Die schleichende Restauration rechten Denkens, (Aufbau Taschenbuch Verlag 1999); Wolfgang Gessenharter, Rechtsextremismus und neue Rechte in Deutschland. Neuvermessung eines politisch-ideologischen Raumes? (Leske + Budrich 1998) and the Polish works: Walter Laqueur, Faszyzm. Wczoraj-dziś - jutro, (Da Capo 1998); Roger Eatwell, Faszyzm. Historia, (Rebis 1999).

2 Otto-Ernst Schüddekopf, Linke Leute von rechts. Die nationalrevolutionären Minderheiten und der Kommunismus in der Weimarer Republik, (Kohlhammer Verlag 1960).

3 Before 1945, the concept of the new nationalism was characterised by the socalled conservative revolution doctrine, which I describe in more depth in my book Niemieckie elity a hitleryzm. O stosunku rewolucyjnych konserwatystów do nazizmu w Rzeszy demokratycznej i hitlerowskiej, (Forum 1994).

4 Hans-Gerd Jaschke, 'Nationalismus und Ethnopluralismus. Zum Wiederaufleben von Ideen der "Konservativen Revolution"', (1992) Aus Politik und Zeitgeschichte. Beilage zur Wochenzeitung 'Das Parlament', (3-4), 3 et seq. Cf also Armin PfahlTraugheber, 'Konservative Revolution' und 'Neue Rechte'. Rechtsextremistische Intellektuelle gegen den demokratischen Verfassungsstaat, (Leske + Budrich 1998), 14.

5 Uwe Backes and Eckha Jesse, Politische Extremismus in der Bundesrepublik Deutschland, (Propyläen 1993), 69 et seq; Thomas Asshauer and Hans Sarkowicz, Rechtsradikale in Deutschland. Die alte und die neue Rechte, (C H Beck 1990), 27.

6 Backes and Jesse, (n 5), 67. Cf Klaus Schönekäs, 'Bundesrepublik Deutschland' in Franz Greß, Hans-Gerd Jaschke and Klaus Schönekäs (eds), Neue Rechte und der Rechtsextremismus in Europa: Bundesrepublik, Frankreich, Grossbritanien, (Vs Verlag Fur Sozialwissenschaften 1990), 218.

7 Günter Bartsch, Revolution von rechts? Ideologie und Organisation der Neuen rechten, (Herder 1975), 21.

8 Jens Mecklenburg (ed), Handbuch deutscher Rechtsextremismus, (Elefanten-Press 1996), 454.

9 Margret Feit, Die Neue Rechte in der Bundesrepublik. Organisation - Ideologie Strategie,(Campus Verlag 1987), 43; Karl-HeinzProhüber, Dienationalrevolutionäre Bewegung in Westdeutschland, (Deutsch-Europäischer Studien 1980), 37.

10 Mecklenburg, (n 8), 942; Richard Stöss, Parteien-Handbuch. Die Parteien der Bundesrepublik 1945-1980, (Westdeutscher 1984), 1948 et seq.

11 Jan Peters, Nationaler 'Sozialismus' von rechts, (Klaus Guhl 1980), 157.

12 Astrid Lange, Was die rechten lesen. Funfzig rechtsextreme Zeitschriften. Ziele, Inhalte, Taktik, (C H Beck 1993), 61 et seq.

13 They pay attention to two books, due to their nationalist content: Gerd-Klaus Kaltenbrunner, Die Herausforderung der Konservativen, (München 1974) and GerdKlaus Kaltenbrunner, Der Schwierige Konservatismus. Definitionen - Theorien Porträts, (Nicolai 1975). 
14 It is further developed in the article 'Odrodzenie ideologii rewolucyjnego konserwatyzmu po drugiej wojnie światowej’, (1996), 19, Studia nad Faszyzmem i Zbrodniami Hitlerowskimi, 170-171.

15 Pierre Krebs, Das unvergängliche Erbe. Alternativen zum Prinzip der Gleichheit, (Grabert 1981), 31.

16 Friedbert Pflüger, Deutschland driftet. Die Konservative Revolution entdeckt ihre Kinder, (Econ 1994), 11 et seq.

17 Kurt Lenk, 'Ein Gran Mussolini. Der publizistische Boom der Neuen Rechte', (1991), Die neue Gessellschaft/Frankfurter Hefte, (8), 728.

18 Bartosz Bolechów, Terroryzm w świecie podwubiegunowym. Przewartościowania $i$ kontynuacje, (Wydawnictwo Adam Marszałek 2002), 259. When it comes to the earlier research on this topic in the FRG cf. Richard Stöss, Die extreme Rechte in der Bundesrepublik. Entwicklung - Ursachen - Gegenmassnahmen, (Vs Verlag Fur Sozialwissenschaften 1989), 45-46.

19 Anna Wolff-Powęska, Polityczne i filozoficzne nurty konserwatyzmu w Republice Federalnej Niemiec, (Instytut Zachodni 1984), 110 et seq; Richard Saage, 'Neokonservatives Denken in der Bundesrepublik' in Irving Fetscher (ed), Neokonservative und 'Neue Rechte'. Der Angriff gegen Sozialstaat und liberale Demokratie in den Vereinigten Staaten, Westeuropa und der Bundesrepublik, (Beck 1983), 68.

20 Patrick C Moreau, 'Die neue Religion der Rasse. Der Biologismus und die kollektive Ethik der Neuen rechten in Frankreich und Deutschland' in Fetscher, (n 19), 121; Diethelm Prowe, 'National Identity and Racial Nationalism in the New Germany. Nazism versus the Contemporary Radical Right', (1997), 15, German Politics and Society, 1 et seq.

21 Cf Irenäus Eibl-Eibesfeldt, Der vorprogrammierte Mensch. Ererbte als bestimmender Faktor im menschlichen Verhalten, (Deutscher Taschenbuch Verlag 1976), passim; Gert Waldmann, Verhaltensforschung und Politik, (1973), Junge Kritik, 17.

22 Rafał Pankowski, Neofaszyzm w Europie Zachodniej. Zarys ideologii, (Instytut Studiów Politycznych PAN 1998), 79.

23 Jochen Termann, Von rechts nach links und zurück. Politische Ideologie des Rechtsextremismus nach dem II. Weltkrieg in Deutschland, Frankreich und Grossbritannien, (Institut für Zeitgeschichte Verlag 1993), 76.

24 Carl Schmitt, Politische Theologie. Vier Kapitel zur Lehre von der Souverenität, (Dunker \& Humblot 1934), 11.

25 Armin Mohler, "Carl Schmitt und die "Konservative Revolution"' in Helmut Quaritsch (ed), Complexio Oppositorum. Über Carl Schmitt. Vorträge und Diskussionbeiträge, (Dunker \& Humblot 1988), 37.

26 Anna Wolff-Powęska, 'Europa brunatnieje', Gazeta Wyborcza, (2001), 14-15 (VII), 16-18.

27 Grzegorz Sadowski, '12 brunatnych gwiazd', (2004), 28, Wprost, (III), 94-96. 


\title{
4 Pro-European, anti-EU? \\ The National Rally and European integration
}

\author{
Marta Lorimer
}

\section{Introduction}

The National Rally (Rassemblement National, RN - previously Front National) ${ }^{1}$ is one of the best-known and well-studied far right parties in Europe. The party was originally founded in 1972 with the aim of bringing together the different strands of the French far right. ${ }^{2}$ Under the charismatic leadership of Jean-Marie Le Pen, in its first ten years of life the party struggled to gain relevance. Following this initial period, referred to in the party as the 'crossing of the desert', ${ }^{3}$ it started gaining some traction in local elections. The RN's first national-level success came in the European Parliament elections of 1984, when it garnered $10 \%$ of the vote and elected its first MEPs. Ever since, the RN has been a force to be reckoned with: while the party has struggled to gain representation at the national level, especially since Marine Le Pen took over the helm of the party in 2011, it has grown into an electoral force representing over one-fifth of the French electorate.

In recent years, the RN's positions on European integration have firmly established it as one of the most Eurosceptic actors in Europe. Most notably, Marine Le Pen advocated a 'Frexit' in her 2012 and 2017 campaigns, and although she has since abandoned this policy as too divisive, the RN remains broadly sceptical of the European construction. Opposition to the European Union (EU), however, was not the RN's starting point, nor is its position on Europe devoid of nuance.

Analysing the RN's approach to European integration, this chapter argues that the party's relationship with Europe is more complex than the term 'Euroscepticism' suggests. From a historical standpoint, the RN has shifted from moderate support for the European Economic Community to staunch opposition to the European Union. As far as ideology is concerned, the RN has long presented an ambivalent position on Europe, constructed on the one hand around a vague backing for an abstract form of European cooperation based on civilisational proximity with other European countries, and on the other hand, on its opposition to the EU as a concrete form of European collaboration that stifles national sovereignty. Finally, it should also be noted that in spite of its opposition to the EU, from a 
practical standpoint, the $\mathrm{RN}$ owes part of its success to it. As with other far right parties, the RN has greatly benefitted from engaging in EU politics, as the EU has provided it with a series of financial and symbolic resources that it would not have otherwise had access to. As Catherine Fieschi eloquently put it, despite their anti-Europeanism, parties such as the RN 'have gained enormously from the solemnity, ritual and political symbolism of the European arena and from the credibility derived through seats in the European Parliament'. ${ }^{4}$

The following sections tease out these complexities. The chapter opens with a brief discussion of the relationship between the far right and Europe. It then hones in on the RN's conflicting relationship with the European Union, exploring in turn the evolution of its positions on European integration, its ambivalent ideological approach to Europe and briefly addressing the practical advantages it has gained from engaging in EU politics.

\section{European integration and the far right}

Far right parties are amongst the most studied phenomena of recent decades. ${ }^{5}$ Existing research has focused on a variety of topics, including their ideological background, ${ }^{6}$ the reasons for their success, ${ }^{7}$ and their effect on national polities. ${ }^{8}$ While in early years, most research focused on these parties' positions on migration, in recent years, their positions on Europe have attracted more attention. As opposition to European integration has become an increasingly visible and shared feature of the far right, ${ }^{9}$ studies have emerged analysing how far right parties articulate their positions on Europe, ${ }^{10}$ the root causes of their Euroscepticism, ${ }^{11}$ as well as the reasons and effects of varying patterns of opposition across parties. ${ }^{12}$

Scholars analysing far right positions towards Europe have noted that, while these actors are frequently presented as 'hard' Eurosceptics, ${ }^{13}$ their relationship with Europe is frequently more complex and diverse that one might expect. ${ }^{14}$ Looking at the development of far right positions over time, for example, researchers have noted that while far right parties converged on a Eurosceptic position, this was frequently not their starting point. ${ }^{15}$ Well known examples of this trend include the Freedom Party in Austria and the Northern League in Italy, who both shifted from overall support to strong opposition to the EU.

Opposition to the EU amongst far-right parties is also not homogenous. First, different parties display varying levels of Euroscepticism, going from more 'compromising' positions to openly 'rejectionist' ones. ${ }^{16}$ Second, these parties also display a measure of ideological ambivalence on Europe depending on how it is defined. As Fieschi, Schields and Woods pointed out, far right parties present two competing visions of Europe. On the one hand, relying on a civilisational definition of 'Europe', they display a proEuropeanism constructed around the idea of a shared ethnic and cultural background amongst Europeans. On the other hand, driven by a fear of 
federalism, further integration and loss of sovereignty, they express a more cautious approach to the European Union as a concrete body. ${ }^{17}$

Finally, it bears noting that the far right's opposition to the European Union has not prevented them from taking part in, and benefitting from, the process of European integration. In fact, the EU has been one of the unwitting supporters of these parties, providing them with resources which have facilitated their establishment and growth. In particular, the proportional and 'second order' nature ${ }^{18}$ of European elections has made it easier for their members to be elected as MEPs, and election has come with a series of financial, symbolic and ideological resources that they could use to consolidate their position in domestic politics. ${ }^{19}$ Accession to the European Parliament has also given them the opportunity to build transnational alliances with like-minded parties across Europe and enhance their legitimacy at home as a result. ${ }^{20}$ In other words, while opposition to EU integration is frequently presented as a marker of marginalisation, ${ }^{21}$ it has also been a source of increased success for these parties.

In sum, while far right parties are frequently viewed as a 'homogenous Eurosceptic bloc',22 their approach to Europe is more complex than commonly stated. From a historical standpoint, their positions have evolved over time. From an ideological perspective, they display ambivalence both within parties and across countries. Finally, in more practical terms, far right parties have also benefitted from the process of European integration that they appear to reject.

\section{The Rassemblement National and European integration}

The Rassemblement National's approach to the European Union displays several of the characteristics described above. Historically, the party shifted from support for European unity to stark opposition to the process. Ideologically, the RN's position is constructed around a distinction between 'Europe' as a civilisation and positive form of identification, and the EU as a concrete and negatively connotated political construction. Pragmatically, finally, the RN has been amongst the main beneficiaries of the process of European integration, as the EU has given it access to the resources that have helped it sustain its growth.

\section{Europositive to Europhobe: the historical evolution of the RN's positions on Europe}

The Rassemblement National's views on European integration evolved significantly over the course of its history, with the party moving from 'euroenthusiast' positions in the early 1980s to 'euroreject' ${ }^{23}$ positions from the late 1980s and 1990s onwards. In the early years of its existence, the RN displayed a broadly positive view of European integration and collaboration. Speaking from a strong anti-communist perspective and perceiving Europe 
to be deeply endangered, it viewed collaboration amongst European nations as a means for Europeans to defend themselves from the Soviet Union, while reacquiring relevance in a bipolar world. The RN's positive approach to integration was well-summarised by Jean-Marie Le Pen in his programmatic book 'Les Français d'Abord' (The French First), in which he argued that given the historical circumstances,

one can now accept the creation of a united Europe in front of external threats. One never associates by natural reflex. When one creates a society, it is because one does not have the means to act alone. It is certain that the threat of Soviet Communism (and the dangers of disintegration by subversion it entails) is also Europe's great chance. It can allow it to define itself precisely against a certain form of danger. ${ }^{24}$

Along with this commitment to European unity in the face of danger, the RN pushed for a European defence that could restore Europe (and its nations) from the decline which ensued following the Second World War, returning it to the status of an international power. Thus, while the party also displayed some more critical stances concerning specific aspects of the EU construction, its opposition remained rather moderate.

The RN's pro-Europeanism was, however, short-lived. From the middle of the 1980s, responding to changes within the party and the European Union, the party began a slow but secure shift towards opposition to the European Union. As far as the EU was concerned, the introduction of the Single European Act marked the beginning of an increasingly close cooperation between European countries based on a primarily economic agenda. This development was at odds with the party's view that European collaboration should be guided by the aim of transforming Europe into an international power able to stand up to the Soviet Union. For example, Bruno Mégret criticised the Single European Act as one which did not do anything to remedy the EU's lack of common defence projects and the absurdity of '350 million Europeans asking 230 million Americans to defend them from 270 million Soviets'. ${ }^{25}$ This critique was entwined with the idea that by privileging economic cooperation, the EU did little to reinforce the common identity of Europeans and their sense of needing to unite against external dangers. ${ }^{26}$ Within the party, the arrival of a group of more markedly Eurosceptic politicians such as Yvan Blot and Jean-Claude Martinez, as well as an increased knowledge (and scepticism) of European processes derived from having become part of the European Parliament prompted a shift to more critical stances which crystalized into firm opposition during the campaign against the Maastricht Treaty. ${ }^{27}$

From the 1990s onwards, the RN adopted a strongly Eurosceptic stance. In addition to the previously noted changes in leadership, a few additional factors may help explain this shift. First, the RN found itself acting in a radically different political context. The collapse of the Soviet Union and the 
emergence of a multi-polar world removed (or at least reduced) the need for European collaboration in military terms. Second, the party responded to further evolutions in the European Union following the adoption of the Maastricht Treaty. If the Single European Act entrenched a certain course of economic integration, the Maastricht Treaty represented a qualitative shift in the process of integration, leading the EU to increasingly intrude on 'core state powers'.$^{28}$ In the RN's eyes, the EU's newly acquired powers represented an unacceptable relinquishing of national sovereignty, which led it to develop its critique of the EU as a power-hoarding body aimed at destroying the sovereignty of European nations. Finally, opposition to European integration also offered a strategic advantage to the RN. Faced with a primarily pro-EU political class, adopting strong anti-EU positions allowed the party to distinguish itself from other political actors, while appealing to sectors of public opinion who opposed European integration, but could not find a party to represent these views. ${ }^{29}$

Opposition to European integration remains an integral part of the RN's message to this day. While the party has oscillated in its views concerning exit from the European Union, ${ }^{30}$ it remains a strong advocate of a different model of integration (a 'Europe of the Nations') based on the preservation of national sovereignty. The following section discusses the RN's ideological approach to European integration in more depth, teasing out additional areas of ambiguity in the party's stance.

\section{Pro-Europe, anti-EU: the RN's ideological approach to 'Europe'}

The historical evolution of the RN's positions on European integration is not the only source of ambiguity in the party's approach to Europe. In fact, the party's ideological approach to the EU is marked by a dual discourse where the RN claims to support a rather abstract 'European civilisation' while at the same time opposing the concrete political project of the EU as both against this European civilisation and its finest product: the nation state.

The RN's claim to be 'pro-European' dates back to its early years. The definition of Europe as a distinct civilisation, for example, was well fleshed out in the previously cited 1984 programmatic book 'Les Français d'Abord', in which Jean-Marie Le Pen defined Europe as

a historic, geographic, cultural, economic and social ensemble. It is an entity destined for action. Europe is currently divided, in decline. Europe is retreating to the borders of the Year 1000, but it guards the possibilities for rebirth, should she rediscover a spiritual, intellectual and political unity and all that has been its spirit: that is, a will to act for civilisation, to refuse to be submerged and vanquished. ${ }^{31}$

The identification of a distinct European civilisation was accompanied by a claim of belonging to it, and, by the end of the 1980s, the assertion that it 
represented this true 'Europe' against an ever-encroaching EU. Coinciding with the development of more critical positions on the EU, this 'pro-Europe, anti-EU' discourse is well-summarised in a 1991 party guide aimed at activists, where it is stated that

the debate on Europe is completely distorted, because there are in fact two radically different conceptions of Europe. One is founded on the idea that the world is destined to homogenise and unite, and that Europe in this perspective is nothing but a stage. (...) The other is founded on the idea that the survival of European nations is threatened and they have to unite to preserve their identity and retrieve their power. Europe is thus conceived as a means to defend the independence of nations or of national identities. The first conception is that of a cosmopolitan or globalist Europe; the second is that of Europe understood as a community of civilisation. The first one destroys the nations, the second one ensures their survival. The first one is an accelerator of decline, the second an instrument of renaissance. The first is the conception of the Brussels technocrats and of establishment politicians, the second is our conception. ${ }^{32}$

Influenced by the ideas of the French intellectuals of the Nouvelle Droite, ${ }^{33}$ and drawing on arguments made by RN leaders in their speeches and in the first number of the party magazine Identité, dedicated to 'Rethinking Europe', the passage clearly draws out the distinction between 'Europe' as the party understands it, and the EU as a concrete political project. While the passage above was still influenced by a Cold War mentality, insofar as Europe is seen as needing to unite in front of a 'danger', it is notable that the distinction between Europe and the EU has remained a visible feature of the party to this day, with Marine Le Pen claiming, for example, that 'even though we are resolutely opposed to the European Union, we are resolutely European, I'd go as far as saying that it is because we are European that we are opposed to the European Union'. ${ }^{34}$

Whereas 'Europe' represents a positive form of identification, the RN's opposition to the EU centres around the view that the EU is a concrete threat to national (and European) identity and sovereignty. This line of critique has also evolved through time. In the late 1980s, for example, the EU was mainly criticised for doing little to protect European identity and foster the 'renaissance' of Europe and its nations as world powers. From the early 1990s onwards, criticism of the EU centred more strongly on the concept of national sovereignty. In this line of criticism, the EU had become a threat to a nation's ability to rule itself and take the decisions that it saw fit. This aspect was also presented as part of a larger ploy to dilute national identity and facilitate the emergence of a 'world-government'.

It is on these two axes that the RN's critique of the EU still builds today. On the one hand, 'Brussels' is accused of harming national sovereignty through excessive supranational legislation and unacceptable limitations on what a 
nation can do. On the other hand, it is accused of facilitating migration and globalisation, two trends which deeply harm national identity. The view of the EU as a harmful construction has led the party to call for a fundamental renegotiation of France's place in the EU and a reform of the Union in the direction of a 'Europe of the Nations', with the possibility of leaving the project should this process be unsuccessful. The importance of this goal to the party was most evident in its 2017 presidential programme, where the very first article stressed the need to

Regain our freedom and the control of our destiny by returning (monetary, legislative, territorial and economic) sovereignty to the French people. For this, a negotiation with our European partners will be pursued, followed by a referendum on our belonging to the EU. The objective is to reach a European project that respects the independence of France, of national sovereignties, and which serves the interests of the people. ${ }^{35}$

In sum, whereas the $\mathrm{RN}$ acknowledges the existence of commonalities between Europeans, and even claims to belong to a European civilisation, this does not lead it to support the EU. Rather, the EU is presented as violating core European values such as national identity and sovereignty. This vocal critique of the EU, however, does not prevent the party from taking advantage of participation in EU institutions. It is to this factor that the chapter now turns.

\section{The benefits of Europeanisation: the $\mathrm{RN}$ as beneficiaries of the $\mathbf{E U}$}

The RN's opposition to European integration has not prevented it from benefitting from European integration. Taking part in European elections and joining the European Parliament, in fact, has provided the party with 'legitimacy, resources and patronage' ${ }^{36}$ which have helped it become a regular presence in French and European politics.

In electoral terms, the RN has benefitted from the European Parliament elections' proportional system. While in national elections, the two-round majoritarian system, coupled with the continued ostracization of the party on the part of mainstream actors, made it hard for the RN to gain seats in the Assemblée Nationale, the proportional system used in European Parliament elections made it easier it to be elected. Thus, while the $\mathrm{RN}$ was present in the French Parliament only between 1986 and 1988, and again after 2012, it has been a regular presence in the European institutions since 1984.

Being a part of the European Parliament has come with both financial and symbolic benefits. Financially, the European Union provides its MEPs with the requisite resources to perform their jobs, and MEPs can gain access to additional funds when they form or join a transnational party group. For a party struggling with its finances, these funds provided material resources which could be used to form its political cadres and maintain a visible presence 
at the national level ${ }^{37}$ - although the $\mathrm{RN}$ has not always made use of the funds in a manner which is in line with the EU guidelines. ${ }^{38}$

From a symbolic point of view, taking part in EU politics has provided the RN with additional clout and legitimacy. As well as gaining access to a new arena in which to present their ideas, RN MEPs have gained the respectability that comes from public office ${ }^{39}$ and from participation in transnational collaboration. ${ }^{40}$ While RN-led transnational alliances have not always been successful, they seem to have acquired more momentum in the last two European Parliament legislatures. The EU may also be seen as having provided the RN with ideological resources which have helped adapt its message in a more appealing way. As argued elsewhere, their aforementioned claims to be 'pro-European but anti-EU' may have helped them build a less nationalist image, while their focus on issues of sovereignty has brought their discourse in line with the mainstream, which may have made their views appear more acceptable. $^{41}$

\section{Conclusion}

This chapter has shown that, like other far right parties, the RN has had a complex relationship with European integration. While being supportive of the process in its early years, following changes in the EU, in the party and in the political context, it shifted to a position of radical opposition. Its ideological approach to the EU is constructed around a 'pro-Europe, anti-EU' stance in which it supports an abstract European civilisation, while rejecting the concrete political project of the European Union. Finally, while the RN has rejected European integration formally, this has not stopped it from benefitting and taking advantage of the process and the additional resources that participating in European integration has offered it.

The observation that the RN has benefitted from the EU (and still benefits from it) also raises some questions concerning whether for all its opposition, the party (and other hard-line opponents of EU integration belonging to the same party family) would actually benefit from seeing the construction disappear. The EU, after all, may have its uses even for those who disapprove of it, and it is unclear whether if given the opportunity to tear it down, these parties would actually be willing to do so. More likely, they may try to reform it into something more aligned with their views, although it remains to be seen whether a 'Europe of the Nations' would be able to function in an effective manner.

\section{Notes}

1 The Front National changed its name to Rassemblement National in 2018. Documents produced by the party before 2018 are cited following the original nomenclature.

2 Jean-Yves Camus, 'Origine et Formation Du Front National' in Nonna Mayer and Pascal Perrineau (eds), Le Front National à découvert, (Presses de la Fondation Nationale des Sciences Politiques 1989), 17-36. 
3 Erwan Lecœur, Un Néo-Populisme à La Française: Trente Ans de Front National, (Découverte 2003), 29.

4 Catherine Fieschi, 'European Institutions: The Far-Right and Illiberal Politics in a Liberal Context', (2000), 53, Parliamentary Affairs, 517, 521.

5 Pietro Castelli Gattinara, 'The Study of the Far Right and Its Three E's: Why Scholarship Must Go beyond Eurocentrism, Electoralism and Externalism', (2020), 18, French Politics, 314-333.

6 Elisabeth Carter, 'Right-Wing Extremism/Radicalism: Reconstructing the Concept', (2018), 23, Journal of Political Ideologies, 157; Cas Mudde, Populist Radical Right Parties in Europe, (Cambridge University Press 2007).

7 Daphne Halikiopoulou and Tim Vlandas, 'Risks, Costs and Labour Markets: Explaining Cross-National Patterns of Far Right Party Success in European Parliament Elections', (2016), 54, Journal of Common Market Studies, 636; David Art, Inside the Radical Right: The Development of Anti-Immigrant Parties in Western Europe, (Cambridge University Press 2011); Herbert Kitschelt and Anthony J Mcgann, 'The Radical Right in Western Europe: A Comparative Analysis', (1996), 75, Foreign Affairs, 140.

8 Roger Eatwell and Cas Mudde, Western Democracies and the New Extreme Right Challenge, (Routledge 2004).

9 Margarita Gómez-Reino Cachafeiro, Nationalisms in the European Arena: Trajectories of Transnational Party Coordination, (Palgrave Macmillan 2018), 63-64; Gary Marks and Carole J Wilson, 'The Past in the Present: A Cleavage Theory of Party Response to European Integration', (2000), 30, British Journal of Political Science, 433, 457.

10 Bharath Ganesh and Caterina Froio, "A "Europe Des Nations": Far Right Imaginative Geographies and the Politicization of Cultural Crisis on Twitter in Western Europe', (2020), 42, Journal of European Integration, 715; Marta Lorimer, 'What Do They Talk about When They Talk about Europe? Euro-Ambivalence in Far Right Ideology', (2020), 44, Ethnic and Racial Studies, 1.

11 Catherine E De Vries and Erica E Edwards, 'Taking Europe To Its Extremes: Extremist Parties and Public Euroscepticism', (2009), 15, Party Politics, 5; Daphne Halikiopoulou, Kyriaki Nanou and Sofia Vasilopoulou, 'The Paradox of Nationalism: The Common Denominator of Radical Right and Radical Left Euroscepticism', (2012), 51, European Journal of Political Research, 504; L Hooghe, G Marks and CJ Wilson, 'Does Left/Right Structure Party Positions on European Integration?', (2002), 35, Comparative Political Studies, 965; Sofia Vasilopoulou, Far Right Parties and Euroscepticism: Patterns of Opposition, (Rowman \& Littlefield International 2018).

12 Reinhard Heinisch, Duncan McDonnell and Annika Werner, 'Equivocal Euroscepticism: How Populist Radical Right Parties Can Have Their EU Cake and Eat It', (2020), 59, Journal of Common Market Studies, 2, 189-205; Vasilopoulou, Far Right Parties and Euroscepticism: Patterns of Opposition, (n 11); Sofia Vasilopoulou, 'European Integration and the Radical Right: Three Patterns of Opposition', (2011), 46, Government and Opposition 223; Bartek Pytlas, 'Hijacking Europe: Counter-European Strategies and Radical Right Mainstreaming during the Humanitarian Crisis Debate 2015-16', (2020), 59, JCMS: Journal of Common Market Studies, 2, 335-353.

13 Aleks Szczerbiak and Paul A Taggart, Opposing Europe?: The Comparative Party Politics of Euroscepticism. Volume 1, (Oxford University Press 2008). 
14 Lorimer, (n 10).

15 Mudde, (n 6), 158-183; Dimitri Almeida, 'Europeanized Eurosceptics? Radical Right Parties and European Integration', (2010), 11, Perspectives on European Politics and Society, 237.

16 Sofia Vasilopoulou, 'European Ingegration and the Radical Right. Three Patterns of Opposition', (2011), 46, Government and Opposition, 223.

17 Catherine Fieschi, James Shields and Roger Woods, 'Extreme Right-Wing Parties and the European Union' in John Gaffney (ed), Political parties and the European Union (Routeledge 1996), 235-253.

18 Simon Hix and Michael Marsh, 'Second-Order Effects plus Pan-European Political Swings: An Analysis of European Parliament Elections across Time', (2011), 30, Electoral Studies, 4; Michael Marsh, 'Testing the Second-Order Election Model after Four European Elections', (1998), 28, British Journal of Political Science, 591.

19 Emmanuelle Reungoat, 'Mobiliser l'Europe dans la compétition nationale. La fabrique de l'européanisation du Front national', (2014), 43, Politique européenne, 120, 133-136; Julia Schulte-Cloos, 'Do European Parliament Elections Foster Challenger Parties' Success on the National Level?', (2018), 19, European Union Politics, 408; Pytlas, (n 12); Marta Lorimer, 'Europe as Ideological Resource: The Case of the Rassemblement National', (2020), 27, Journal of European Public Policy, 1388.

20 Nicholas Startin, 'Where to for the Radical Right in the European Parliament? The Rise and Fall of Transnational Political Cooperation', (2010), 11, Perspectives on European Politics and Society, 429, 439; D McDonnell and A Werner, 'Respectable Radicals: Why Some Radical Right Parties in the European Parliament Forsake Policy Congruence', (2017), 25, Journal of European Public Policy, 2, 1-17; D McDonnell and A Werner, International Populism: The Radical Right in the European Parliament, (Hurst 2019).

21 Gilles Ivaldi, 'Contesting the EU in Times of Crisis: The Front National and Politics of Euroscepticism in France', (2018), 38, Politics, 278, 286; Paul Taggart, 'A Touchstone of Dissent: Euroscepticism in Contemporary Western European Party Systems', (1998), 33, European Journal of Political Research, 363.

22 Almeida, (n 15), 244.

23 Petr Kopecky and Cas Mudde, 'The Two Sides of Euroscepticism: Party Positions on European Integration in East Central Europe', (2002), 3, European Union Politics, 297.

24 Jean-Marie Le Pen, Les Français d'abord, (Carrère - Michel Lafon 1984), 155-156.

25 Bruno Mégret, cited in Front National, 'Passeport Pour La Victoire', (Front National 1989), 59.

26 Olivier Pichon, 'L'illusion Du Primat de l'économie Ou l'Europe à l'envers', (1989) La Lettre de Jean-Marie Le Pen, 5; Front National, Militer Au Front, (Editions Nationales 1991).

27 Emmanuelle Reungoat, 'Le Front National et l'Union Européenne: La Radicalisation Comme Continuité' in Sylvain Crépon, Alexandre Dézé and Nonna Mayer (eds), Les Faux-semblants du Front national, (Presses de Sciences Po 2015), 228-229.

28 Philipp Genschel and Markus Jachtenfuchs, 'More Integration, Less Federation: The European Integration of Core State Powers', (2016), 23, Journal of European Public Policy, 42. 
29 Emmanuelle Reungoat, 'Mobilizing Europe in National Competition: The Case of the French Front National', (2015), 36, International Political Science Review, 296.

30 For example, while it advocated in favour of 'Frexit' in the 2002, 2012 and 2017 presidential elections, following the unsatisfactory results of the 2017 presidential election it has abandoned the stance (at least temporarily).

31 Le Pen, (n 24), 154.

32 Front National, Militer Au Front, (n 26), 115.

33 Tamir Bar-On, 'Fascism to the Nouvelle Droite: The Dream of Pan-European Empire', (2008), 16, Journal of Contemporary European Studies, 327; Tamir BarOn, 'Transnationalism and the French Nouvelle Droite', (2011), 45, Patterns of Prejudice, 199; Pierre-André Taguieff, Sur La Nouvelle Droite: Jalons d'une Analyse Critique, (Descartes \& Cie 1994).

34 Marine Le Pen, 'Discours Dans Le Puy-Du-Dome', (2017), https://rassemblem entnational.fr/discours/discours-de-marine-le-pen-dans-le-puy-de-dome/ accessed 16 September 2020.

35 Front National, '144 Engagements Présidentiels', www.frontnational.com/leprojet-de-marine-le-pen/ accessed 16 September 2020.

36 Pippa Norris, Radical Right: Voters and Parties in the Electoral Market, (MyiLibrary; Cambridge University Press 2005), 255-256.

37 Reungoat, 'Mobiliser l'Europe dans la compétition nationale', (n 19), 133-136.

38 For example, since 2014 the party has been at the centre of a 'fake job' scandal, where some of its MEPs where charged with using EU funds to pay Francebased staff.

39 Reungoat, 'Mobilizing Europe in National Competition: The Case of the French Front National', (n 29), 299.

40 Startin, (n 20), 439.

41 Lorimer, (n 19). 


\title{
5 Giorgia Meloni's new Europe \\ Europe of sovereign nations in the Brothers of Italy party manifestos
}

\author{
Joanna Sondel-Cedarmas
}

\section{Introduction}

The Brothers of Italy (Fratelli d'Italia, FdI), the Italian conservative-sovereign party, is an extremely interesting phenomenon on both the Italian political scene and in European politics. The group, established in December 2012, is attracting growing public support in the country, but is also among the most significant far-right European parties, one which is critical of the European Union (EU) and its policies. Regardless of its declared ties with the postfascist party Italian Social Movement (Movimento Sociale Italiano, MSI) (which operated on the Italian political scene from 1946 to 1994), FdI has steadily increased its popularity: starting with the 2014 European Parliament election (3.7\%), through the 2018 parliamentary election (4.3\%), and the 2019 European Parliament election (6.5\%), and attracting $16.2 \%$ of the votes in the regional elections at the end of September 2020. ${ }^{1}$ At the end of 2019, Giorgia Meloni, the current party leader, who is one of the most popular politicians in Italy according to public opinion polls by Ipsos, was also included by the English daily The Times as among the most significant personalities able to meaningfully influence European politics in $2020 .^{2}$ The aim of this chapter will be to analyse the Fratelli d'Italia's vision of Europe based on their press materials, party programmes and Giorgia Meloni's public appearances, with a particular emphasis on their concept of the European Union and its policies from 2014 to today.

\section{'In defence of God, fatherland and family' - sovereignty according to Fratelli d'Italia}

The Fratelli d'Italia group was officially established on 21 December 2012 by three former members of The People of Freedom (Popolo della Libertà, PdL) party: Giorgia Meloni, ex-minister for youth policies in Silvio Berlusconi's 4th government; Ignazio La Russa, defence minister; and Guido Crosetto, undersecretary in the Ministry of Defence. The party initially used the name Fratelli d'Italia - Alleanza Nazionale to emphasise its historical ties with National Alliance (Alleanza Nazionale, AN) and Italian Social Movement - National

DOI: $10.4324 / 9781003226123-8$ 
Right (MSI-Destra Nazionale), thus not distancing itself from neo-fascist traditions. ${ }^{3}$ As noted by the political scientist Piero Ignazi, FdI is a party with a clearly defined identity, referring to the tradition of MSI, filtered into AN. ${ }^{4}$ Its main programme points, such as national pride, which often takes on a nationalistic character, an active role of the state in the economy, sensitivity to the problems of Southern Italy and social rights, refer to this political culture. FdI is also characterised by its strong leadership. ${ }^{5}$ Until 2014, Ignazio La Russa, who had been the leader of the MSI Fronte della Gioventù youth group in the 1970s, and subsequently a close associate of Gianfranco Fini, was the party's chairman. The current leader of the party, Giorgia Meloni (born in 1977), although she has repeatedly declared 'she was never a fascist for anagraphic reasons', ${ }^{6}$ willingly quotes the long-time MSI secretary Giorgio Almirante during her speeches, proposes replacing the 25 April holiday, which commemorates the fall of fascism, with another anniversary which 'does not divide Italians so much', ${ }^{7}$ and in 2017 she strongly criticised a bill that intended to make proclaiming fascist propaganda a crime (Legge Fiano). ${ }^{8}$ The party's logo also refers to neo-fascist traditions, with its three-colour flame or torch reminiscent of the historical symbol of the MSI. ${ }^{9}$

The party's programme was fine-tuned at the second FdI congress, which took place on 3 December 2017 in Trieste (the so-called Tesi di Trieste per il Movimento dei patrioti), ${ }^{10}$ at which Giorgia Meloni announced her intention of creating a 'patriot movement'. In addition to strict identity slogans related to extreme right-wing culture, and not only those identifying with MSI and AN, FdI presented itself as a national conservative and sovereign party. In its programme, the group refers to the principles of national sovereignty, freedom, democracy, justice and social solidarity, and strongly emphasises its attachment to the national tradition. As Meloni declared during the Atreju demonstration in September 2019, FdI is a sovereignty party because it wants to 'defend God, the Fatherland and the family'. Similarly, in a speech on 3 February 2020 at the National Conservatism Conference, organised in Rome by the Edmund Burke Foundation and Nazione Futura, the party leader referred to the programme slogans of a former US president, Ronald Reagan, while presenting her Manifesto for a New Europe: 'Defence, Fiscal, Social'. In Meloni's opinion, more than any other president in US history, Reagan represented the words of the Preamble to the US Constitution: 'We the People', symbolising the principle of national sovereignty. As she emphasised, the nation is a commonality of traditions and values that create its distinctive identity. At the convention, Meloni also presented three main elements of the political and economic revolution on which the new Europe should be based: 1) 'a patriotic soul' (sovereign), striving to defend its national interests and sovereignty of the people (the nation); 2) economic freedom and the correct relationship between the state and taxpayers; 3) social values which should uphold religious and moral values, understood as 'the noblest objective of every political action'. All these values can be included in the mottos: 'God, freedom, nation' or 'God, fatherland, family' which are - as 
Meloni has accentuated- key in the life of every nation as places where they are 'kept and passed on to future generations'. ${ }^{11}$

Fratelli d'Italia defends the traditional family model, emphasising its criticism of gay marriage and the same-sex adoption of children. They attack the new notion of gender particularly strongly, believing that its supporters are trying to impose a cultural model in schools. The party's programme is also characterised by an extensive social programme, establishing, among others, the introduction of the 'family rate' (quoziente familiare), i.e. the dependence of the tax rate on the number of family members, the establishment of free nurseries, family benefits (such as allowances of EUR 400 per month for children up to 6 years of age), paid parental leave for mothers of children up to 6 years of age, and the introduction of a reduced VAT of $4 \%$ on children's products. In addition to demographic issues, they have an avowed desire to combat unemployment, especially among young people, and the protection of jobs by creating the right conditions for Italian companies to operate, produce and compete in the world. To this end, they proposed the introduction of a limited flat tax for companies based in Italy and employing Italian workers. As they declare, in terms of economic policy they are not supporters of protectionism, they support the free market, but oppose 'rampant globalism' without rules, which supports primarily economic powerhouses and great international financiers. For a model, Meloni points to the policy of US President Donald Trump, who managed to develop the American economy by guaranteeing the freedom of business operations, reducing taxes and bureaucracy, as well as public investments in the field of infrastructure and defending national economic interests. Following the example of Trump's policy, Meloni emphasises that priority should be given to Italians when granting social benefits, housing and access to nurseries (Prima gli italiani). The FdI leader believes the welfare system in Italy should be reformed in order to guarantee benefits for the weakest members of society, in particular those with disabilities, and to lower the retirement age to 60 years, while increasing minimum pensions. At the same time, she has called for the elimination of the reddito di cittadinanza, the Five Star Movement's (M5S) flagship project, as, according to Meloni, it does not promote the creation of new jobs, does not fight poverty, but only causes 'citizens dependence on politics' and penalises those employed on regular employment contracts. ${ }^{12} \mathrm{As}$ she stressed on numerous occasions during the 2019 European Parliament election campaign, this amount should be allocated to help companies and enterprises that employ Italians or to limit the increase of the VAT rate in Italy. In the party's programme, FdI also attach great importance to the observance of the principles of loyal international competition, in particular defending Made in Italy against the illegal use of Italian trademarks by foreign companies (Italian sounding). To achieve this, they even propose the introduction of 'civilisation tariffs' (dazi di civiltà) against countries that do not respect Italian standards for wages, health and safety at work and environmental protection. 
An important point in the FdI programme is the goal of rebuilding and restoring the authority of the state, one with a strong central executive, while reducing bureaucracy and simplifying the entire administrative machine. They are in favour of a presidential republic, with direct elections for the president or the head of government, which will guarantee national unity while maintaining local autonomy. ${ }^{13}$ As Meloni has repeatedly emphasised, while not denying the importance of a united state, Italy's national identity is made up of the historical wealth of its various local communities. Thus, a strong government cannot be synonymous with a centralised and forceful state apparatus. FdI also attach great importance to ensuring security and order in the state. They have called for the strengthening of police numbers, an increase in the salaries of security service officers, as well as the introduction of an appropriate legal framework aimed at punishing attacks and other acts against them. Considerable controversy was garnered by FdI's proposal in 2018 to remove the provision recognising torture as a crime (legge sulla tortura) from the Italian penal code. According to the party's politicians, it prevents officers from the security forces from properly performing their work. The group also supports the use of the army in the fight against terrorism and organised crime. It promotes a ruthless policy against illegal immigration, even proposing a blockade of the Mediterranean Sea with the use of the Italian navy to stop the illegal influx of immigrants. It has even proposed banning NGO ships which rescue migrants from accessing Italian ports. It should also be noted that FdI opposes the introduction of ius soli, emphasising that the acquisition of Italian citizenship is not a right but a privilege. Only those who know the language and respect the laws, culture, and historical and religious traditions of Italy can be granted citizenship.

In international politics, FdI attaches great importance to relations with the Arab Mediterranean countries, in particular with Libya, which is considered to be the main point of reference for Italian interests in terms of security, border control and energy supplies. As they emphasise, after the Arab Spring, it is in Italy's interest to seek cooperation with the above-mentioned countries to stabilise the situation in North Africa and the Middle East, and above all to support governments that choose to fight terrorism. It should also be noted that for FdI, Italy is primarily a part of the West, natural allies of other European nations and the United States, and in terms of military cooperation it is a part of NATO. While the pro-Atlantic choice is essentially in line with the political tradition of the (post-fascist) right in Italy, ${ }^{14}$ the positive assessment of Russia and Vladimir Putin is something new in the FdI programme. In Meloni's view, Russia should be a part of a broader West in a common struggle to defend its shared identities and values. The party leader highly rates Putin's policy, who - like Donald Trump - attaches importance to national pride and identity at a time when these values are ignored in many countries. FdI also supports the economic and strategic cooperation of the EU with Russia, stressing that it can ensure lasting peace and stability on the continent, and help in the fight against terrorism. 


\section{'Europe-nation' or sovereign nation states in a sovereign Europe}

In Tesi di Trieste, Fratelli d'Italia pointed out the importance of the common tradition of the Italian nation, its culture of remembrance, as well as sovereignty and freedom. Great importance was attached to the idea of identity, to rebuilding the idea of fatherland in contemporary politics, after a long period when this value was diminished or even denied. Similarly, identity cannot be separated from the common national tradition which plays a very important role in the lives of individual nations. It is thanks to the rediscovery of a common tradition, the sense of national belonging, that the values of the fatherland can be rebuilt. As underlined in the party's programme, this task is particularly difficult to accomplish in Italy, as only since Carlo Azeglio Ciampi's presidency have the importance of symbols, ceremonies and secular rituals through which the national community manifests itself (including the national anthem, which until recently was considered provisional) been rediscovered and emphasised.

As they claim:

While all other member states have a developed sense of national belonging, clearly defined national interests which they intend to defend, a certain framework of national myths and symbols, Italy lacks these elements or they have been discovered relatively recently. ${ }^{15}$

Referring to the statement of the historian Ernesto Galli della Loggia about the death of the fatherland in the wake of the crisis in 1943, related to the dismissal of Mussolini and the division of Italy into a fascist part and one controlled by the Resistance, it was argued that during the entire period of republican Italy no political entity dared to openly follow the national interest and to cultivate feelings towards the fatherland. FdI believes that patriotism and the feeling of belonging to a single fatherland are the only ways to build greater social and generational cohesion. Love for one's fatherland is a necessary condition for feeling respect for the homelands of other nations, and for creating a dialogue necessary for the common development of various European nations. It is also the only chance for Italians to come out of the state of 'limited sovereignty', cultural, political and economic subordination, and to heal the wounds of the civil war (1943-1945) that characterised the birth of republican Italy. This issue concerns not only domestic but also European politics. As highlighted in Tesi di Trieste, the main problem of the current EU model is the deliberate omission of the national identities of individual member states. The EU forgets that nations are 'living organisms' and tries to deny them, instead of trying to emphasise their richness and the common source from which the idea of Europe was born. The only chance for the existence of a nation, and also of Europe, is to constantly affirm the will to belong to a common fate. Referring to the aforementioned concept of the daily referendum of Ernest Renan and the concept of the Italian philosopher 
Giovanni Gentile, who proclaimed that living together, cultivating the same customs, as well as tradition and language are the 'matter' of which the nation is made, FdI emphasises that the nation must be aware of this matter. At the same time, however, it should to accept the awareness of the content 'creating its own spiritual being' in order to fully become a nation. ${ }^{16}$ The same is true for a confederation of states, where a 'free choice' is particularly needed to justify giving up some part of national sovereignty. This concept was developed by Giorgia Meloni in the Manifesto for a New Europe, presented at the previously mentioned Conservative Convention in Rome on 3 February 2020. As she declared, today's EU is trying to implement 'the Soviet plan to destroy national and religious identities'. ${ }^{17}$ Referring to an idea from The Virtue of Nationalism by Israeli philosopher Yoram Hazona, the FdI leader emphasised the need to restore conservatism to its traditional environment, that is, the idea of national belonging. Meloni stressed that Fratelli d'Italia's vision of Europe is opposed to what the 'Brussels techno-bureaucrats' are trying to impose on them, striving to strip nation states of their prerogatives, trying to grant full sovereignty to the EU. As she noted: "we fought against and defeated communism not to have it replaced with a new internationalist regime, but to allow independent nations to defend their freedom, identity and sovereignty again'. ${ }^{18}$ Referring to the words of Pope John Paul II from the encyclical Memory and Identity, the leader of FdI noted that the very concept of the fatherland contains a deep connection between the spiritual and material aspects. Democracy without value turns into demagogy. In the opinion of Meloni, John Paul II, the 'patriot pope', who proclaimed that 'there is no Europe without Christianity', was well aware that belonging to one nation and shared historical memory is the source of every human being's freedom. The values Meloni refers to are: the family, understood as 'natural society', inextricably linked with human nature; the right to live in peace and dignity in one's fatherland; as well as Christianity and the Christian identity of Europe, which are the subject of constant attacks from the sides of 'distorted secularism'. As Meloni emphasised, this secularism, on the one hand, fights against the symbols of the Christian tradition, and on the other, opens up to the most intransigent forms of Islam. Europeans cannot be deprived of the roots that individual nations have formed over the centuries, because they are all descendants with a common history. Denying tradition leads to the disintegration of Europeans, depriving them of their sense, direction and power to act, as well as destroying the spiritual structure of European civilisation. This weakness of the cultural identity of European nations also makes them defenceless against the attack of radical Islam. Hence, the FdI leader criticises the model of Europe that denies its Judaeo-Christian and classical roots and tries to subordinate the identity and principle of autonomy of individual nations to radical universalism. This universalism supports the principle of multiculturalism, which allows for an uncontrolled flooding of Europe by immigrants from outside Europe. This problem was already outlined in the party's programme in 2017. 
As noted in Tesi di Trieste, 'Blinded by absolute damnation of "hatred of foreigners", with the absence of understanding of the growing hostility of Europeans towards migrants, the ruling castes are not aware of the hatred that an ever-growing proportion of foreigners (and even descendants of secondand third-generation migrants) harbour towards the societies that took them to their bosom'. ${ }^{19}$

The resurgence of aggressive and intolerant nationalisms is one consequence of this, as well as the theories of white racial superiority, which appeared to be long gone. The antidote to this danger should be the cultivation of patriotic feelings, based on defence and emphasising the cultural diversity of Europeans, the multiplicity of their cultures and different lifestyles. This is in contrast to the standardisation required by 'wild globalisation'. In this concept, FdI refers to the ideas of the philosopher Renato Cristin, presented in the book I padroni del caos, which was not by accident considered the party's manifesto. As Meloni declared, the theme of defending identity, which is the leading theme of the book, is also the focal point of the FdI programme and is at the root of all the problems that Italy faces without the help of Europe. The only true Europe can be one composed of free and sovereign nations. In order to rebuild Italy and - going further - to rebuild Europe, the ideas of European spirit and European identity must be reappropriated. ${ }^{20}$ In this way, FdI's postulate of rebuilding European identity is connected with a radical criticism of multiculturalism, which leads to abandoning one's own identity in favour of cosmopolitan universalism, one devoid of both barriers and roots. FdI also criticises the tendency to exaggerate political correctness and the socalled 'other's rhetoric' by which it understands the 'tendency of Europeans to accuse themselves and to extol "the alien"'. ${ }^{21}$ In their opinion, this leads to the degradation of their own identity and the development of anti-identity, anti-European, and anti-Western ideology. As they emphasise, the process of Islamisation is taking place on the European continent through a 'gentle invasion', i.e. the mass immigration of a Muslim population, which takes place with the support of Saudi Arabia, Qatar and Turkey, as well as by financing mosques, centres of Islamic culture and strengthening Islamic influence in the economic, cultural and informational spheres. In FdI's opinion, this phenomenon constitutes a threat to the Greco-Latin-Christian identity of Europe, and questions the principles of equality, democracy, freedom and secularism of the state on which the whole of Western civilisation is based. Therefore, the party calls for limiting Islamic immigration to Italy and Europe, stressing that whoever wants to live in Italy must accept and respect Italian culture and identity. They also refuse to remove symbols of the Christian tradition from public places in the name of 'misunderstood secularism'. ${ }^{22}$

It should be noted that FdI looks with interest towards the Visegrad Group countries, which they believe defend the spirit of a true and historic Europe. As highlighted in Tesi di Trieste, in central European countries such as Poland, Hungary, Czech Republic, Slovakia or Austria, a vision of Europe as an alternative to the oikophobic-xenophilic progressivism of the 
West emerged. At the same time, the Visegrad Group has become a symbol of opposition to the extensive bureaucracy of the EU: "when eurobureaucrats say "more Europe", it means "more Brussels" and less national consciences; however, when defenders of the European spirit and way of life say "more Europe", it relates to the greater identity of each of its nations and the continent as a whole ${ }^{23}$. Therefore, 'more Visegrad, less Brussels!' became one of FdI's mottoes. Giorgia Meloni returned to this concept in an interview with Gino Coala on 11 November 2018 for Libero Quotidiano, where she declared her intention to establish an alliance between FdI and conservatives and sovereigntists from the Visegrad Group countries:

They are a model of how to be in Europe and not have to give up one's own national sovereignty. (...) We want to focus on relations with the Visegrad Group countries which defend Europe's borders against uncontrolled immigration. ${ }^{24}$

According to Meloni, it is with them that FdI must conduct a dialogue, and not with the Franco-German treaty that 'has taken over Brussels'. ${ }^{25}$ The model for the Italian right should be the Hungarian Prime Minister Viktor Orbán, who 'acts in the interest of his people, defends Europe's Christian roots by opposing the imposed islamisation' ${ }^{26}$ It should be noted that Meloni also declared her support for the Spanish far-right party Vox, as well as for the policies of its leader Santiago Abascal. As she emphasised during the parliamentary elections in Spain in November 2019, she admires Abascal's fight against secessionism in the name of a strong and united Spain. In the opinion of FdI's leader, all movements promoting independence and separatist slogans in Europe lead to the weakening of nation states, thus pursuing the interests of big capital, lobbyists and international speculative financiers. A fatherland, where sovereignty belongs to the people and not to supranational structures, is the last bulwark defending citizens against the onslaught of mondialism and globalisation. For this reason, defending the fatherland of Italy means, in Meloni's concept, the protection of Italian identity, freedom and sovereignty.

\section{'Europe of nations' versus 'Europe of technocrats'}

The Fratelli d'Italia programme clearly refers to Charles de Gaulle's vision of a Europe of fatherlands, a Europe of nation states bound by a common cultural tradition. Like de Gaulle, FdI is against a 'technocratic Europe', based on an extensive system of EU bureaucracy that tries to create a European super-state. FdI present themselves as patriots and Europeans because they believe in a Europe of nations, a community of nations, with different languages and traditions, but which nevertheless emphasise their relationship and connections. ${ }^{27}$ They advocate a foreign policy based on the political will of sovereign states and on international cooperation, one which respects the 
subjectivity of states. They also highlight the primacy of the Italian constitution and Italian legal norms over community legislation. These beliefs were expressed, among others, in a draft bill tabled by FdI in February 2019 in the Italian Parliament removing references to the EU from the Italian constitution because, as Meloni argued, it constitutes a restriction on Italian sovereignty. ${ }^{28}$

FdI declare that they do not share either the idea of 'naïve European federalism', which preaches the need to abandon one's own sovereignty, or the two-speed Europe model. As highlighted in Tesi di Trieste, the historical and cultural process which has become increasingly dynamic since the 1960s, has led to the creation of a Europe (both institutionally and nationally) characterised only by a myth of apparent integration based on a common goal, namely the defeat of nationalisms and an extensive bureaucratic apparatus. One can discern that the criticism of European federalism, combined with the vision of a united Europe based on a confederate model, fits into the Italian post-fascist right's vision of Europe. It arose as early as in the late 1970s in the Eurodestra programme, developed by the MSI leader Giorgio Almirante together with Jean Louis Tisier-Vignancour of Parti des Forces Nouvelles and Blas Piñar of Fuerza Nueva. ${ }^{29}$ As Almirante pointed out in an interview with Michele Rallo in 1978, 'Europe must not become a collection of semi-sovereign states, devoid of a unifying element, left to the slaughter by political and financial speculations of foreign powers' ${ }^{30}$ His idea of the 'Nation of Europe' (Nazione Europa) meant a united Europe that leaves the individual characteristics of the nations that make it up intact. This concept found its fundamental expression in the idea of Europe as 'United in Diversity' (unità nella diversità), which was adopted in the Treaty establishing the Constitution for Europe in 2004. ${ }^{31}$ It should be noted that the then leader of AN and Italian Foreign Minister, Ginafranco Fini, worked on the creation of the treaty. Fini, in an interview with Carlo Fusi in 2003 entitled L'Europa che verrà, supported a confederal model for the EU. This would be one which emphasised the diversity of the various European nations which together formed a harmonious whole, and he compared them to a 'mosaic, in which the particular elements retain their distinctive features and identity but together form one, common image'. ${ }^{32}$

The project to create a European confederation of free and sovereign nation states in place of the current European Union was developed in a 9-point programme prior to the 2019 European Parliament election. FdI declared that their model of Europe is not a current supranational entity, ruled by bureaucrats and technocrats, who are not directly elected by citizens and who try to impose their will on European nations, but a community of states that can cooperate in key issues and at the same time make autonomous decisions in internal national affairs. ${ }^{33}$ As Giorgia Meloni frequently emphasised during the campaign, earlier European treaties should be revised and a new pact establishing a confederation of free and sovereign states created. This would lead them to cooperate on key strategic issues, ranging 
from security to migration, from the common market to foreign policy, while reducing an overly complex bureaucratic machine, one incapable of representing the interests of the member states and their citizens. As the FdI leader pointed out, the challenges of world politics mean that the relations between European nations should be ever stronger. Only a united Europe will be able to effectively compete with the United States, China, Russia and India. The current model of the EU, where 'bureaucracy, technocracy and lobbyism prevail', means that it is unable to respond to the needs of individual European nations. Hence, as declared by the leader of FdI, the capital of Europe should not be Brussels, 'which is the seat of lobbyists, but Athens or Rome, where the European civilisation was born'. ${ }^{34}$

It should be noted that FdI's critical attitude towards the EU not only manifests itself in negating the federalist model, but also in criticising the dominant role of Germany and France in European politics. In their opinion, 'Europe has become the playground for France and Germany', 35 because these countries use European institutions to pursue their own interests, to the detriment of other member states, especially Italy. It should be noted that FdI also criticises the harsh austerity policy imposed on Italy by the EU, which, in their opinion, has led to impoverishment of society, the crisis of Italian companies and the consequent rise in unemployment. According to FdI, the current direction of the EU policy should be changed in order to increase expenditure on public investments, primarily in the sphere of infrastructure, transport, internet network, expansion and modernisation of construction, as well as increasing national security. Similarly, the criticism of FdI in relation to EU policies manifests itself in the issue of the common European currency. This problem was already raised in the programme developed before the 2014 European Parliament election, entitled Head held high in Europe (In Europa a testa alta), where FdI called for Italy's 'controlled abandonment of the Eurozone'. ${ }^{36}$ In the programme before the 2019 European Parliament election, although efforts were made to moderate this postulate, it was noted that the issue of exchanging the lira had turned out to be particularly unfavourable for Italy. A proposal was also presented for the EU to launch compensation measures for countries that, like Italy, had suffered damage related to the introduction of the common currency. ${ }^{37}$

FdI is also very sceptical about the European Central Bank's (ECB) monetary policy, seeing it as one which penalises the Italian economy. In their opinion, the scope of the intervention of the Central Bank and the competences of national central banks should be re-discussed, so that the banking system becomes a support tool for enterprises and families, and not an element serving international financial speculation. It should be noted that FdI was particularly sceptical about the EU financial assistance programme for the Italian economy in light of the COVID-19 crisis. Giorgia Meloni strongly criticised the decision of Giuseppe Conte's government to seek help from the European Stability Mechanism (ESM) because, as she stressed, the ESM could make Italy even more dependent on the Franco-German axis. The FdI leader was in favour of 
applying to the International Monetary Fund (IMF) and launching 'Special drawing rights' (SDR), while supporting the proposal of former finance minister Giulio Tremonti to issue state vouchers (the so-called bond patriottici) in imitation of vouchers granted to Italians in 1948, that would be purchased by the ECB as special forms of long-term loans. ${ }^{38}$

\section{'Together with the conservatives to change Europe' - Fratelli d'Italia and EU policies}

On 6 November 2018, Meloni announced her intention to run for the European Parliament along with a group of European Conservatives and Reformists (ECR): 'Together with the conservatives to change Europe'. ${ }^{39}$ As she emphasised, the Italian right has been a part of the conservative group since 2009, hence this affiliation is a natural one. ${ }^{40}$ According to the FdI leader, the European conservatives are the only true democrats because, by defending a sovereign nation state, they also try to defend the sovereignty of their citizens. Hence, only conservatives are able to build a true 'Europe of nations and identities' ${ }^{41}$ In an open letter written with Jan Zahradil and published in Corriere della sera on 15 May 2020, Meloni announced that the choice of affiliation in the EP was also connected to shared values and ideals contained in the 2009 Prague Declaration. As she pointed out, the current model of the EU, 'a bureaucratic superstate that regulates and controls against the will of individual nations, has not worked'. Meloni stressed that the group of conservatives is ready to challenge the 'Brussels Europe' to create a Europe that would defend European 'identity, borders and the real economy'. According to the FdI leader, this new Europe should defend its borders against uncontrolled immigration, the security of its citizens against threats posed by Islamic fundamentalism, while maintaining a social market economy, capable of supporting enterprises without imposing additional taxes, and guarding the freedom of the individual by fighting against cultural relativism, in the name of defending a common Christian civilisation based on the family. ${ }^{42}$ Similarly, after meeting with the leader of the Law and Justice party Jarosław Kaczyński, which took place in Warsaw on 3 April 2019, in the presence of Ryszard Legutko, the vice-president of the ECR in the European Parliament, Meloni announced on Twitter:

We will jointly build a Europe of sovereign nations that remembers its identity and believes in the real economy. We are strengthening our position in the party of European Conservatives and Reformists and we are tightening cooperation with the pro-independence members of Visegrad. ${ }^{43}$

Meloni also returned to this vision in an interview with Lorenzo Lamperi in Affari Italiani on 15 June 2019, in which she presented FdI's position in the new European Parliament, focusing on the role that the Conservatives 
and Reformists group can play in the process of changing Europe. ${ }^{44}$ As she emphasised, it is the foreign policy and defence of external borders, as well as the fight against terrorism, that should be left to the discretion of Brussels, while sovereign member states should assume all of the competences regarding internal policies. It should be noted that Meloni also presented the idea of building a broader alliance which would encompass the European People's Party (if she moves further to the right, closer to the political line of Hungarian Prime Minister Viktor Orbán) and the populists Matteo Salvini and Marine Le Pen, where the conservative group should play a key role as a bridge between the sovereigntists and the European People's Party (popolari). As she pointed out, the growing importance of populist parties and groups in Europe, from the British Brexit referendum, to the results of elections in France, Germany, Austria, the Czech Republic, Poland and Hungary, means the defeat of traditional parties based on the vision of a federalist Europe. Meloni, making a distinction between the 'identity populism' characteristic of patriotic movements in Europe, and 'demagogic justicist populism' (populismo giustizialista), which was particularly widespread in Italy, noted that identity populism can be an antidote to the development of a society devoid of traditional ties and common national affiliation. FdI shares many features with the populist agenda: despite some differences resulting from different national characteristics, movements of this type are characterised by criticism of the technocratic nature of the EU, the bipolar EU policy, based on the alliance of Christian Democrats and Socialists, defending the Christian roots of Europe, opposing Islamisation, uncontrolled immigration, defending small and medium-sized enterprises against the international power of financiers and large international corporations. Emphasising the differences between the FdI programme and the policies promoted by Matteo Salvini and Marine Le Pen, Meloni highlighted that it is not enough to reject the current EU model, but one needs to propose an alternative programme. Unlike the populists, FdI do not intend to limit themselves to a 'sterile fight against the system', but to translating the above-mentioned slogans into concrete reform proposals that they intend to implement in policy at the national and European level. ${ }^{45}$

\section{Conclusions}

There is no doubt that FdI's idea of Europe allows the party to be classified as Euro-realistic or representing so-called 'soft Euroscepticism' ${ }^{46}$ Their vision of the European Union is based on a confederation of sovereign and free nation states, bound by a common cultural tradition which is based on Greco-LatinChristian roots. FdI opposes the federal model of the EU, calling it a 'technocratic Europe' based on an extensive system of EU bureaucracy that is trying to create a European super-state. Like the other European parties that make up the European Conservatives and Reformists, they attach great importance to the national traditions and identities of individual member states. They are critical of the policy of multiculturalism, considering it a threat to European 
identity, as well as a means to Islamise Europe. The party's Eurosceptic attitude is most clearly manifested in its postulate to leave the eurozone and in its criticism of the Franco-German axis as dominant in Europe and pursuing its interests at the expense of other member states.

\section{Notes}

1 'PiazzaPulita, sondaggio Index: Giorgia Meloni sorpassa il M5s, balzo per Fratelli d'Italia dopo le regionali', Libero Quotidiano, (2 October 2020), www. liberoquotidiano.it/news/politica/24735840/piazzapulita-sondaggio-indexgiorgia-meloni-sorpassa-m5s-balzo-fratelli-d-italia-dopo-regionali.html accessed 12 October 2020.

2 Massimo Rebotti, 'Giorgia Meloni ora preoccupa Salvini: sondaggi, viaggi in Usa e maxi cene con i fan', Corriere della Sera, (Milano, 16 February 2020), www. corriere.it/politica/20_febbraio_15/viaggi-usa-sondaggi-maxi-cene-fan-1-agendagiorgia-che-preoccupa-matteo-d4f7c06c-5033-11ea-a036-d715f3c65007.shtml accessed 2 July 2020. At the end of September 2020, Giorgia Meloni was chosen as the president of European Conservatives and Reformists.

3 Roberto Chiarini, 'La Destra italiana. Il paradosso di un'identità illeggittima', (1991), 185, Storia contemporanea, 584-585.

4 Piero Ignazi, 'Msi-An. La nostalgia al binario morto', in P. Ignazi, I partiti in Italia dal 1945 al. 2018, (il Mulino 2018), 109-135.

5 Ignazi, 'Qualcosa di nuovo, a destra. Dal declino di Berlusconi all'ascesa di Meloni', La Repubblica, (Roma, 8 January 2020), 34.

6 Pierluigi Battista, 'Lavacri e nostalgie gli Msi e i conti con il passato mai fatto del tutto', Corriere della sera, (Milano, 22 March 2016), www.corriere.it/politica/16_ marzo_22/lavacri-nostalgie-ex-msi-conti-mai-fatti-tutto-il-fascismo-168974dcefa6-11e5-9957-88f22239b898.shtml accessed 2 July 2020.

7 During the celebration of the 25 April in 2020, Meloni proposed turning the holiday into a commemoration of the victims of all wars and the COVID-19 epidemic. See 'E' polemica sul 25 aprile. Fratelli d'Italia propone di trasformare la festa di Liberazione nella giornata per ricordare i caduti di tutte le guerre e del Covid 19 con la canzone del Piave al posto di Bella ciao', La Repubblica, (Roma, 18 April 2020). www.repubblica.it/politica/2020/04/18/news/fratelli_d_italia_sul_ 25_aprile_ricordiamo_i_caduti_di_tutte_le_guerre_e_del_covid_la_canzone_del_ piave_al_posto_di_bella-254391375/ accessed 2 July 2020.

8 Giorgia Meloni's speech, in which she compared Mussolini to Fidel Castro, was especially controversial as she stressed that Mussolini also did 'good things', and that only the introduction of an authoritarian system and some measures, such as racist laws and involving Italy in the war are blameworthy "Meloni (AN): "Mussolini come Castro". E i giovani di Polo e Unione si dividono', Corriere della sera, (Milano, 9 December 2008). www.pressreader.com/italy/corriere-dellasera/20061209/281930243491674 accessed 2 July 2020.

9 From February 2014 to 3 December 2017, the party's official name was Fratelli d'Italia - Alleanza Nazionale. At the second congress in 2017, the party's symbol was also modified: the white, red and green flame with the MSI inscription remained, while any references to AN have been removed. Massimo Rebotti, 'Meloni cancella AN dal simbolo. "Non siamo più solo il partito della destra". Ma resta la fiamma 
missina', Corriere della sera, (Milano, 4 December 2017), www.corriere.it/politica/ cards/fiamma-disegno-almirante-nuovo-logo-fratelli-d-italia/via-an-piu-fiammasimbolo-fratelli-d-italia_principale.shtml accessed 12 July 2020.

10 Filippo Del Monte, 'Fratelli d'Italia: A Trieste nasce il Movimento dei patrioti', www.centro-destra.it/wordpress/fratelli-ditalia-nasce-movimento-dei-patrioti/ accessed 27 June 2020.

11 Francesco Storace, 'Giorgia Meloni mette sul piatto dei Conservatori il Manifesto per la Nuova Europa dei valori', Secolo d'Italia, (4 February 2020) www. secoloditalia.it/2020/02/giorgia-meloni-mette-sul-piatto-dei-conservatori-ilmanifesto-per-la-nuova-europa-dei-valori/ accessed 20 June 2020.

12 'Cancellerei il Reddito di cittadinanza', https://tg24.sky.it/politica/2019/05/24/elezi oni-europee-giorgia-meloni-tribu.html accessed 15 April 2020.

13 A presidential system has been a fixed topic on the agenda of the post-fascist right, starting with MSI through AN. Marco Tarchi, Cinquant'anni di nostalgia, (Rizzoli 1995), 233-234.

14 As declared by Gianfranco Fini in a book interview by Carlo Fusi L'Europa che verrà: 'Europe and the USA are two faces of the same coin, called the West. The West is a category that includes Europe and the United States of America, because they share the same values, because nations are closely related to each other and it is not only thanks to emigration from the Old Continent towards the other side of the Atlantic. To think of a hostile European policy towards the United States would be to deny that we are one another's children, that Americans are descendants of Europeans, but at the same time that Europe is to some extent a daughter of the United States'. Gianfranco Fini, L'Europa che verrà. Il destino del continente e il ruolo dell' Italia, (Fazi Editore 2003), 33. See also Marco Tarchi, Recalcitrant Allies: the Conflicting foreign Policy Agenda of the Alleanza Nazionale and the Lega Nord, in Christina Schori Lang (ed), Europe for the Europeans: the Foreign and Security Policy of the Populist Radical Right, (Routledge 2016), 187.

15 'Una filosofia dell'identità', in Tesi di Trieste, www.fratelli-italia.it/le-tesi-trieste/ accessed 20 June 2020.

16 Ibid.

17 Storace, (n 11).

18 Ibid.

19 'Una filosofia dell'identità', (n 15).

20 Ibid.

21 As Cristin wrote: 'a newcomer is by definition reliably good, or at least a carrier of positive values that Europeans should adopt and absorb in order to integrate with foreigners $[\ldots]$ the process of migration seeking to replace old nations with some transnational project is controlled remotely - or at least supported - by some elite'. According to the quoted philosopher, this leads to a complete uprooting, replacement of European peoples by semi-stateless people who correspond to the old will (emerged with Marxism and agreed with the catholic left's messianism) to create a new humanity, which cleanses the Western man of his traditional thinking and his alleged historical guilt. See 'Nowa Europa i władcy chaosu. Rozmowa z Renato Cristinem', (14 February 2020), Teologia polityczna, https://teologiapolityczna.pl/ liberalizm-i-wladcy-chaosu-rozmowa-z-renato-cristim-1 accessed 28 June 2020.

22 'Patrioti per difendere la nostra identità dal processo di islamizzazione dell'Europa Europa', in Tesi di Trieste, (n 15).

23 'Una filosofia dell'identità', in Tesi di Trieste, (n 15). 


\section{Joanna Sondel-Cedarmas}

24 'Patrioti per difendere la nostra sovranità nazionale in Europa', in ibid.

25 Ibid.

26 'Meloni a Budapest, asse con Orban: no all'immigrazione e piani per la natalità', Corriere della sera, (Milano, 1 March 2018), 8.

27 Patrioti per difendere la nostra sovranità nazionale, in Tesi di Trieste, (n 15).

28 Emanuele Bonini, 'Far-right party seeks to kick EU out of Italian constitution', www.euractiv.com/section/politics/news/far-right-party-seeks-to-kick-eu-out-ofitalian-constitution/ accessed 4 July 2020.

29 Simone Paoli, 'Euroright. The Extreme Right in the European Integration Process, 1979-1989', in Lucia Bonfreschi, Giovanni Orsina and Antonio Varsori (eds), European Parties and the European Integration Process 1945-1992, (Peter Lang 2015), 319-325.

30 Michele Rallo (ed), Almirante. Intervista sull'Eurodestra, (Thule 1978), 7.

31 Fini, (n 14), 38.

32 Ibid.

33 'Dall'Unione Europea alla confederazione europea di Stati sovrani' in Programma Elezioni Europee, www.flipsnack.com/fratelliditalia/programma-europee.html accessed 18 June 2020.

34 Ibid.

35 'Faremo rispettare l'Italia in Europa', in ibid.

36 'Scioglimento concordato dell'Eurozona', in ibid. Meloni also returned to the issue of Italy's exit from the Eurozone in 'Manifesto per un'Europa dei popoli', presented in March 2017 cf 'Ecco il "Manifesto per un'Europa dei popoli": 7 punti per costruire l'Europa delle Nazioni', www.giorgiameloni.it/2017/ 03/25/manifesto-uneuropa-dei-popoli-7-punti-costruire-leuropa-delle-nazioni/ accessed 15 June 2020.

37 'Contro la finanza speculativa e le distorsioni dell'Euro', in Europa a testa alta, www.fratelli-italia.it/programma-europa/ accessed 12 July 2020.

38 'Włochy nie liczą już na Europę. Początek italexitu', (7 April 2020), Rzeczpospolita www.rp.p1/Koronawirus-SARS-CoV-2/304079888-Wlochy-nie-licza-juz-naEurope-Poczatek-italexitu.html accessed 10 June 2020.

39 Antonio Pannullo, 'Meloni: "Con i Conservatori per cambiare la Ue. Pronta a candidarmi", Secolo d'Italia, (6 November 2018), www.secoloditalia.it/2018/11/ meloni-con-i-conservatori-per-cambiare-la-ue-pronta-a-candidarmi/ accessed 15 April 2020.

40 After the 2009 European election, Alleanza Nazionale joined the nationalistconservative Union for Europe of the Nations group. AN received nine seats, making it the largest representation in the UEN group. The second largest party was Prawo i Sprawiedliwość (7 seats). Daniele Pasquinucci, Uniti dal voto? Storia delle elezioni europee 1948-2009, (FrancoAngeli 2013), 326. See also Gino Coala, 'Giorgia Meloni, l'alleanza in Europa con i Conservatori di Fitto: "Così batteremo la sinistra e Macron", Libero quotidiano, (Milano, 11 November 2018), www. liberoquotidiano.it/news/politica/13397616/giorgia-meloni-alleanza-popolariconservatori-trionfo-elezioni-europee-fitto.html accessed 15 April 2020.

41 'Ecco il "Manifesto per un'Europa dei popoli": 7 punti per costruire l'Europa delle Nazioni', www.giorgiameloni.it/2017/03/25/manifesto-uneuropa-dei-popoli7-punti-costruire-leuropa-delle-nazioni/ accessed 15 June 2020.

42 'Meloni, i Conservatori e l'idea di Ue: "Sia una comunità di Stati sovrani", Corriere della sera, (Milano, 15 Maggio 2019). It should be noted that FDI declared 
their willingness to join the ECR group before the European elections in 2014. The results of the aforementioned European elections, in which they got $3.66 \%$ of the votes, did not secure them seats in the European Parliament at the time.

43 Maria Pankowska, 'PiS brata się z postfaszystami z Włoch. Dołączają do frontu Europy "Ojczyzn"', https://oko.press/pis-brata-sie-z-postfaszystami-z-wlochdolaczaja-do-frontu-europy-ojczyzn/ accessed 15 June 2020.

44 'Meloni: “Così va cambiata l'Europa. Governo, quanti errori in politica estera", (15 June 2019) affariitaliani.it www.affaritaliani.it/politica/geopolitica/ giorgia-meloni-fratelli-d-italia-governo-europa-intervista-610662.html accessed 15 April 2020.

45 Ibid.

46 Aleks Szczerbiak and Paul Taggart, 'Theorising Party-Based Euroscepticism: Problem soft Definition, Measurement and Casuality', in Szczerbiak and Taggart (eds), Opposing Europe?: The Comparative Party Politics of Euroscepticism, (Oxford University Press 2008 vol 2), 238. 


\title{
6 The League of Salvini \\ From a Europe of regions to a Europe of nations
}

\author{
Gianluca Passarelli and Dario Tuorto
}

\section{The League back again on stage}

The electoral rise of Salvini's League is one of the novelties on the Italian political scene. In the past, the League Nord took a prolonged part in centre-right governments led by Silvio Berlusconi. As of 2018 it became the main member of the centre-right coalition and, the following year, the top Italian party. For roughly a year it formed an alliance with Movimento 5 stelle (M5s) which had polled the most votes in the 2018 general election - and managed to govern the country, pushing through some contested measures of debatable utility (most of all, the Security Decree to manage migrant flows, which brought Italy under scrutiny by international human rights organisations and clashes with European institutions). Following its coup in the 2019 European elections $(34.3 \%)$, the League challenged the government it belonged to on a confidence issue and tried to force an early election on the crest of its electoral triumph, but was compelled to rejoin the opposition. Its successes at by-elections that same year did nothing to change the national political equilibrium. In 2020, Salvini's party has gone ahead with its bid for hegemony in government and the centre-right coalition, although having to face the rise of a potential right-wing competitor, Giorgia Meloni's Fratelli d'Italia (FdI). The League's plans for consolidation and return to power have been further complicated by the grave health and economic crisis caused by the Covid-19 epidemic. Though creating opportunities to delegitimise the government in office, the emergency has highlighted the limitations of being in opposition, cut off from decision-making and unable to control the political agenda. This has lost the party much of its media visibility.

The chapter sets out to explore the reasons behind the Salvini League's attainment of national, and on some occasions even international, prominence; what resources it deployed to tackle and surmount the critical phase in the first period; and the prospects and limitations it faces in Italy's present socio-political and economic predicament. Besides reconstructing what changes have occurred in the electoral line-up in broad outline, the League's own internal organisation and the policies it is pursuing, the following pages will concentrate on one particular aspect: the European side to the League's 
plans. In the course of time, its relations with Europe have fluctuated wildly, from initial overtures to later scepticism. While the institutions of Europe have been a principal target of verbal party broadsides, a web of alliances with other Eurosceptic and sovereignist formations continent- (and even world-)wide has increasingly affected the League's political strategy, providing it with a platform which it hitherto lacked, or could not exploit.

\section{The Northern League in the Italian political context: from the early years to the crisis of 2012}

Formally, the Northern League was founded in $1991,{ }^{1}$ though its roots were inextricably planted in the independence and autonomy movements arising in the 1960s-1980s in several northern Italian regions, especially around the Liga Veneta (LV, or Venetia League). Initially it was a story of organisational difficulties and meagre electoral results. Only by the political exertions of Umberto Bossi, its founder and historical party secretary, did the party manage to weld together the many localist formations that had been vying for hegemony. The political target was to reactivate the territorial cleavage ${ }^{2}$ that split northern from southern Italy. That historic fault-line had been smoothed over (before any talk of a divide) in the second half of the 19th century by national unification, handled with military abruptness under fascism, and eventually given formal recognition in the 1948 Constitution of the Republic, thanks to its introduction of a regional design which would be formally adopted in 1970. From the separate autonomy movements, the Northern League inherited policies and values that would see it through the ensuing years of political competition, down at least to the early years of the new millennium: the importance of regional identity and self-government, above all. Further to these basic values, it developed outspoken criticisms of the party system, the centralising state and the corrupt 'consociationalism' or powersharing habits of the ruling class. These points would reappear in the future in the guise of populism and anti-partyism.

Come the general election of 1992, the party gained excellent results in the northern regions such as Venetia (17\%) and Lombardy (23\%), its presence hastening the crisis and the end of the First Republic's political system in Italy. The League functioned as a political detonator, giving electors who no longer identified with the party they had come from a chance to make their views heard. Some of those who abstained on principle found it an option for returning to the urns; while it offered a clear choice for those who felt that policies which Italy had never known (federalism, for instance) needed to be represented. One of the main rallying calls that the League used, at least in the very early days, was the rediscovery of local identities through use of dialect, the promotion of local history, along with an aggressive stance towards non-natives. To begin with, the southerners were targeted in deliberately racist terms serving to amplify the claims of Lombardy, and hence the whole North, to a central role in politics and the economy. ${ }^{3}$ 
The founding of Silvio Berlusconi's party, Forza Italia, came as a challenge to the League's electoral expansion. Allying with Forza Italia in 1994 earned it a place in government, but the alliance was short-lived. The entente broke down partly owing to Berlusconi's entanglement with the magistracy, but above all in light of the 1994 European election result, where Forza Italia came out ahead of the League. Fearing some of his voters might be siphoned off, Bossi broke with the coalition. Friction between the two formations brought the government down and caused the centre-right to lose an early election in 1996. For the League it was the start to a period of paradoxes. They polled more voters than ever, despite standing aloof from the other groupings and pressing ahead with a more and more extreme demand for the northern regions - Padania - to secede from the rest of Italy and set up a federal Po Republic. The swing towards local independence marked a de facto transition: from being the party representing a federation of regional leagues, it became a kind of 'union' party for the North as a whole. But despite the early promise of the polls, absence from government and non-participation in coalitions made it hard for the League to carry through its policies and stand up to the challenge of Forza Italia. Isolated and beginning to lose electoral ground, Bossi forced the party and its grumbling grassroots into yet another U-turn when he signed a pact with the Polo delle Libertà (the centre-right coalition).

The 2001 general election brought a majority in parliament for the coalition and the right to govern the nation. For the League is was a paltry outcome, the worst in its history (only $4 \%$ of the poll), but its place in the alliance earned it three ministries and a political-institutional role that far outweighed its electoral substance. Throughout that mandate it focused chiefly on two policies curbing immigration and devolution - which culminated in the passing of two bills. In the first matter, the party's efforts secured the approval of a clampdown on foreigners entering and settling in Italy. The second consisted of a constitutional reform whereby, among other things, the regions were granted exclusive legislative powers over certain sectors (education, administrative police, health). The new political turn of events spelt the end of the party's marginalisation. If one discounts the parenthesis of 2006-2008 (the electoral defeat of the centre-right, allowing in a centre-left government), the League can be said to have remained in government for nearly the whole first decade of the millennium. And as of the victorious 2008 election, it entered a new period of expansion: the League's third wave, ${ }^{4}$ during which the party found a foothold in areas outside the 'red' region of Emilia Romagna. ${ }^{5}$ In just over twenty years, the Northern League had gone from the role of a small systemchallenger to being the longest intact formation in the whole national political system; from a nondescript force concentrated in a handful of provinces, to a key player in the nation's centre-right coalition.

To judge the League's performance before Matteo Salvini raised the tempo, one has to reconstruct the way the party's aims, ideas and strategies developed over time. As already outlined, the League phenomenon can be traced back 
to a family of regionalist parties that forced themselves into the public eye on a European scale within a few decades. ${ }^{6}$ That it should have caught on even outside these original regions is nonetheless intriguing. Unlike other parties of the kind, the League Nord arose in an area rather weak in historical and cultural identity; it managed to achieve an impressive electoral result and earned its place in the governing line-up, projecting issues of territory and decentralisation onto a national platform. To use a classification scheme that already exists, ${ }^{7}$ it should be ranked among the 'challenger' parties expanding from their presumed ethnic group and taking up political issues that range from post-materialism (environment, civil rights, abolishing nuclear energy) to anti-modernism (curbing immigration, security, law and order). On the one hand, the League intercepted, interpreted and extended the northern protest from an anti-political slant, using localism against the state and the traditional political system and stoking the centre-periphery controversy. On the other hand, electoral support for the new League has gone on expanding, shifting its territorial anchorage.

In time, the original independence movement has turned into a 'catchall party for the scared', funnelling fear of globalisation towards right-wing populism. In this slow but steady evolution, the key date was 11 September 2001 when the West came under attack, an event from which the party wove its Christian-nationalist identity. Halting immigration and defending the local dimension have always been League policies. In Bossi's view, the party must stand guard over the local territory, with its identity and traditions. But only since 2001 has such group conflict taken on the guise of a clash of civilisations, the West versus Islam. This shifting of the battlefield from the social to a cultural and identity plane has enabled the League to extend into swathes of the population sensitive to issues other than territorialism. In League propaganda immigration has become a danger, no longer for northern Italy, but for the whole nation and the West at large. That is why its foreign policy has gradually shifted and broken with the past. Whereas the League of the 1990s stood out as opposing the Gulf War and supporting Milošević, Serbia in the Balkans War, 2001 marked a distinct about face in its position: support for the war in Afghanistan and the ensuing missions in Iraq in the name of a common identity and the higher Western interest.

This shifting order of priorities among the basic values (from the local community to the primacy of a people/civilisation) is completed by a party swing to anti-Europeanism. Until Italy joined the Eurozone, the League was broadly pro-European Union. In that period, the party was in favour of continent-wide integration as a key serving the northern regions (L'Europe des regions) as a potential option for leaving the nation state. ${ }^{8}$ That pragmatic strategy had been maintained throughout the phases when the party was in government. On the foreign front, the European Union was the butt of political attacks in defence of Northern identity and independence for its 'peoples'. But on the home front the party toed the coalition line with hardly a murmur. There are several classic instances of this attitude of simultaneous revolt and 
acquiescence: a vote for the European Constitution being approved, and for the Treaty of Lisbon, on which internal party discord was scotched for overriding political reasons. During the governments led by the centre-right coalition the League had had a chance to play the card of intransigence-onprinciple, only to show loyalty and compliance, in actual fact, by toeing the proposed line. Pragmatism twinned with a party penchant for tough talk but within government: keeping a high profile of external protest so as to tranquillise its electors, but meanwhile negotiating with allies towards a stance justified by the raison d'état. Partnership with a party like Forza Italia, which took issue with some policies but broadly aligned with the European Popular Party, yielded a perfect combination of extremism and moderation which suited both leaderships. Only later, once Italy had joined the Euro Club, placing the independence issue in jeopardy, did the League begin to speak out in tough terms against a European project which it found inimical to the various peoples and their traditions. ${ }^{9}$

The last years of Bossi's League coincided with a period of acute difficulty for the country. In 2011 the Berlusconi government, which included the League, was compelled to surrender the helm to the new technical government of Mario Monti. With his past record as a European commissioner, Monti was, to the League, the ideal whipping-boy, an expression of international finance, power in the hands of the Central European Bank and the bureaucrats of Brussels. The emergence of a technical government supported by both sides gave the League a chance to stand as sole opposition, banking on failure by the Monti cabinet and popular discontent with its policies. This bid by the party to cash in on the crisis came to an abrupt halt in 2012 when an internal scandal burst (an inner circle of League leaders found to be investing in diamonds and using party finds for personal reasons). This spelt débâcle for Bossi - hitherto the unquestioned leader - and paved the way for a new phase under Matteo Salvini.

\section{The new League in the Europe of radical-right populism: the acceleration of a process}

The moral crisis became an electoral crisis and, after a short period of transition, the leadership passed into the hands of Matteo Salvini, who made drastic changes to alliances, organisation and guidelines. Under Salvini, the party went more vertical, slackening the ties that bound the central office to grassroots activism and the administrative moves of local party leaders. The balance tipped towards the person in full charge of the dominant internal coalition, marginalising the old guard and all who were not solidly behind him. For external relations, the party secretary set up a communications staff and cultivated his own profile, first on the TV channels and then the social networks. The new image was of a politician who could tackle and solve issues close to people's daily reality and within the bounds of common sense. From Bossi's charisma over his own people, the new, more populist 
leadership addressed the electorate at large. Having wrested internal control, Salvini went on successfully to carry out his declared intent: to put the League Nord behind him and introduce change whilst keeping continuity by exacerbating processes that were already operating and made all the more evident by external circumstances (a global economic crisis, stumbling blocks dogging the European project). The party as it emerged from this operation was clearly national/nationalist, and more markedly right-wing.

The first point of change was radical. As outlined in the first section, the League was founded as a federalist, autonomist and secessionist movement bent on detaching the northern regions institutionally from the rest of Italy. The utopia of independence failed to take off and foundered for want of allies prepared to boost it on a national and international scale. That stalemate, and the altered background circumstances, explain why Salvini upped the tempo: from the early slogan of 'North First' to 'Italians First', which meant a more overtly nationalist and sovereigntist stance.

The decisive move consisted of giving greater weight to the issue of immigration, projecting it as a matter of national defence. Even in the past the League had waved the banner of anti-immigration, although the plans it advocated were tailored to the North. The new twist consisted of heightening distrust of Europe and the single currency. This took the issue onto a platform where parties of the populist radical right had gained continent-wide consensus and set up a sturdier network of alliances than in the past. Opposition between local and global was already part of Bossi's League; now it was transposed into a crusade involving whole nations - and no longer regions within nations - seeking to extract themselves from would-be supranational control. In this case, Salvini's strategy was clear-cut, entailing the tactical abandonment of the secessionist cause by a rather high-handed elimination of the party symbol and the word 'Nord' from its name. For the League, independence gave way to a campaign against globalisation, immigration and a single-currency Europe. The whole framework was a new one: the "party of the North' faded into a project for nationalising programmes, watchwords and above all consensus. But though this change of tack was enough to make the League nationalist, it was not yet national. Although support began to grow throughout the country, the actual 'nation' was North Italy, not to be blazoned as such in political parlance, but to be defended against global competition by economic policy and investment. As for the rest of the country, it remained an appendix serving the cause of electoral expansion. And in that light one should interpret the resumption of the political battle for 'differentiated autonomy' with a demand to increase the number of issues on which regions should have legislative, organisational and budgetary independence as well as decision-making powers.

The League's second identity question has been over where it stands in terms of political ideology. Over the years Salvini has strengthened links with European populist radical-right formations. This has gone ahead even where the nationalist leanings of that political family clash or jar with the party's 
original stance. Data on electorate attitudes show that since 2012 the League has swung distinctly rightwards, completing a process that was already under way a decade earlier (see Figure 6.1). In the 1990s, votes came from the centre of the ideological and political spectrum; thereafter, more extreme attitudes have begun to be the rule. League propaganda has increasingly highlighted immigration, and that is the issue on which the transformation can most easily be read. Outright xenophobia was there from the beginning but has gradually reached the point where the League electorate is more hostile to immigrants than the average Italian and even the other centre-right parties. It is a striking fact that the party's growth in the ballot has brought not a softening of key issues, but further extremism and harshness of line. This feature regards not just attitudes on immigration but 'cultural' questions such as the campaigns against abortion and in favour of traditional families against homosexual couples.

The new League has made the field of the extreme right in Italy more accessible, ${ }^{10}$ partly because it has managed to give it a supranational setting. Like other European leaders such as Marine Le Pen, Salvini has enabled the right-wing option to be judged via opportunities that each crisis has brought. Hostility towards minorities has become justified as the need for collective protection against the uncontrolled effects of globalisation, and for rebooting the nation as a place of localism, not globalism. As with the Front National/ Rassemblement National (FN/RN), the League may be described as postideologically cashing in on right-wing extremism - a political object that is normally hard to manage but can be launched anew or tailored according to circumstances or political expediency. But unlike the FN/RN, the League can here trade on its undeniable experience in playing the party of 'protest within government' and 'opposition within the institutions'.

Another line of interpretation worth considering links the party to populist movements, such as the case of the Five Star Movement in Italy. ${ }^{11}$ Some of the hallmarks of populism were present from the outset: aversion to politicians and intellectuals, harking back to local tradition, reference to charismatic figures, common sense, the language that people speak. But the League of the early days had no marked nationalism or anti-communism, or indeed any clear right-wing affinities on the part of its electors. ${ }^{12}$ That interpretational puzzle gradually began to clear when, halfway through the 'Noughties', the League radicalised its political programmes, bolstering ties with a distinct area of European populism, the new Right with its penchant for nationalism, nativism and authoritarianism which had not been associated with other political expressions of populism. ${ }^{13}$ De facto the League joined the sovereigntist club without possessing any national identity value in its background. Ideal allies were Marine Le Pen's FN/RN, the Belgian Vlaams Belang, and Austria's FPÖ. In 2017 it joined 'Europe of nations and freedom', a political group within the European Parliament. Other relations were secured with political entities broadly belonging to the so-called Visegrád Group (Poland, Czech Republic, Slovakia and Hungary). In this, the League jumped on the 
bandwagon of a long-established trend among extreme-right parties, namely using denunciation of the 'European threat' as a key factor in building political success. ${ }^{14}$ Reference to these alliance scenarios amplified what was only a latent streak of populism in the present League's right-wing nationalist anti-Europeanism. Emphasis on the corruption of politicians actually applies more to transnational elites than to the Italian political cadre, showing how adoption of sovereignism chiefly stems from the need to move the party onto a European scale.

As a member of the populist radical right, the League grasped the importance of broadening its consensus to a popular electorate abandoned by the Left and penalised by the crisis. Other European parties of the same family also display this quality, profiting especially from the decline of the socialist parties. ${ }^{15}$ As things stand, the League's operation is only half completed. Its leaders have painted the image of a party seeking to be interclass, a receptacle for electors linked by their values and viewpoints rather than by objective conditions. But survey sampling suggests that the party core has changed relatively little: it is still largely composed of middle-aged electors in midcareer or close to retirement, fairly secure in their jobs and concerned at their salary losing its purchasing power. As in the past, the League has gained votes among the ranks of the self-employed, especially in small and medium business enterprises. The worker component (salaried workers in the main) has slowly become more sizable but not yet preponderant and certainly not enough to support the claim that the party has invaded the factory floor or caught on among the lower classes (see Table 6.1). Again, it is still struggling for a foothold among public employees, especially at executive level, or indeed among the precariously or un- employed. ${ }^{16}$

Salvini's new corporative plan to harness the 'animal spirits' of national productive capitalism (against supranational economic elites) along with the socially 'left behind' impoverished by the crisis, is proving a thorny conundrum as to the kind of policies to promote and interests to defend. One of the catch-all issues the party has exploited is anti-Europeanism, as mentioned previously. As a different approach to tackling the social and economic discontent felt by part of the country, the League has scaled up the local-global opposition, turning regionalist claims into a protest by the entire nation state against Europe and its policy of austerity. Euroscepticism has increasingly become a core topic of League propaganda. Compared with the other Italian parties, League voters prove to be far more hostile: one-third deem European integration a misfortune for the country, while over half voice criticisms of the euro (see Table 6.2). Such attitudes have grown more deeply rooted, merging with a more general state of disaffection. Since 2000 the percentage of Italians who identify with Europe and support the Union has slumped from a high of $60 \%$ to one of the lowest levels on the continent (just over $30 \%$ ). ${ }^{17}$ For the League voters, the effect of criticising Europe has been, more than in other parties, to view their territorial roots in almost completely national terms with minimal sense of the supranational. Historically the League 


\section{Gianluca Passarelli and Dario Tuorto}

Table 6.1 Sociodemographic profiles: age, occupational status, social class (\%)

\begin{tabular}{lcc}
\hline & $\begin{array}{c}\text { Vote for } \\
\text { League }\end{array}$ & $\begin{array}{c}\text { All } \\
\text { voters }\end{array}$ \\
\hline Age & & \\
$18-30$ & 13.0 & 18.0 \\
$31-60$ & 46.8 & 47.8 \\
$>60$ & 40.2 & 34.2 \\
Total & 100 & 100 \\
Occupational status & & \\
Employed & 69.2 & 67.4 \\
Unemployed & 30.8 & 32.6 \\
Total & 100 & 100 \\
Occupation classes (\% of those employed) & & \\
Clerical workers, public sector & 14.6 & 23.7 \\
Skilled and unskilled workers, small industries & 22.9 & 19.8 \\
Skilled and unskilled workers, big industries & 36.5 & 37.0 \\
Self-employed (autonomous, professionals, managers, etc.) & 26.0 & 19.5 \\
Total & 100 & 100 \\
Social class (\% of those employed) & & \\
Bourgeoisie & 26.7 & 20.6 \\
Clerks & 38.2 & 48.4 \\
Trades and crafts & 10.5 & 9.6 \\
Working class & 24.6 & 21.4 \\
Total & 100 & 100 \\
(N) & $(276)$ & $(1869)$ \\
\hline
\end{tabular}

Source: Itanes, Post-electoral survey 2018 CAWI (unweighted data).

Table 6.2 Positions on European integration and the euro (\%)

\begin{tabular}{lll}
$\begin{array}{l}\text { Votefor } \\
\text { League }\end{array}$ & $\begin{array}{l}\text { Votefor other } \\
\text { centre-right } \\
\text { parties }\end{array}$ & $\begin{array}{l}\text { All } \\
\text { voters }\end{array}$ \\
\hline
\end{tabular}

Italy's membership of the European Union is:

\begin{tabular}{lccc} 
Positive & 19.0 & 36.7 & 45.6 \\
Negative & 36.3 & 26.1 & 21.4 \\
Neither positive nor negative & 40.3 & 35.2 & 29.1 \\
Don't know & 4.4 & 2.0 & 3.9 \\
Total & 100 & 100 & 100 \\
Having the euro is: & & & \\
Positive & 19.0 & 33.4 & 41.0 \\
Negative & 55.4 & 43.9 & 33.6 \\
Neither positive nor negative & 22.3 & 20.2 & 21.6 \\
Don't know & 3.3 & 2.5 & 3.8 \\
Total & 100 & 100 & 100 \\
(N) & $(273)$ & $(199)$ & $(1850)$ \\
\hline
\end{tabular}

Source: Itanes, Post-electoral survey 2018 CAWI (unweighted data). 
elector felt strongly anchored in his/her home territory. Over the course of time a different sense of belonging has set in, focusing on the nation and by contrast hostile to Europe. ${ }^{18}$ Small wonder, then, that fear of losing Italian identity through membership of the European Union (a cultural fear, and absolute) should be one of the most constantly voiced concerns, together with fear of seeing one's own or one's country's interests undervalued by supranational institutions.

Its stance on Europe is one of the most emblematic expressions of how the League sees its political role today. The League brand of anti-Europeanism includes a range of different nuances and positions, the full extent of which can only be gauged by reconstructing party development over the years leading to a different kind of territorial identification and claims from in the past. As the previous section made clear, the League's position on Europe was not always one of protest but a means to an end in achieving domestic objectives. The years of crisis were an important testing-ground for the party. That was the period when anti-Europeanism became more explicit, a brand of 'populism' arising in opposition to Brussels bureaucracy, national antidevelopment policies and supranational overriding of the nation's claims. ${ }^{19}$ Nonetheless, the basic party line does not substantially differ from the past. In Europe, the League sticks to opposition in word, enabling it to demand autonomy yet stay in government. Showdown is confined to a symbolic level, always kept to a national dimension as a device for putting 'pep' into the coalition and among the electorate. The League viewed Europe first as a way of heightening sub-national nationalism (the regional identity of the North); then it contrasted European 'bureaucracy' with the alleged manufacturing specialty of the Padania area, and finally, when the mirage of secession evaporated, it pinned its colours to nationalism. In other words, Salvini is banking on representing an Italy standing out against Brussels, that symbol of supranational integration which would take the edge off identity and make nonsense of representing socially and geographically grounded interests.

Much like Euroscepticism, sovereignism has served as a tool to turn the League into a catch-all party on the Italian political scene. By standing out for sovereignty, the party has been able to make clear its position on economic issues and welfare. The prevailing attitude of the League voter is still distinctly pro-market and pro-private, above all as concerns labour relations and support for measures to reduce taxation (see Table 6.3). However, in line with the trend of other populist radical-right parties, that position has combined with a new sovereigntist idea as to the need to defend the home market (Italy's companies and its workforce against the threat of globalisation), even extending to forms of statist and interventionist policies that are alien to the traditionally liberalist conservative Right. On a social protection ticket, the bid to broaden the electoral basis and include salaried workers, women and families has led the party to take an overtly chauvinistic approach. Preferential treatment for Italian citizens in the labour market and in access to welfare, social security and even health programmes has made it possible to combine policies to cut 
Table 6.3 Positions on economic issues

\begin{tabular}{lccc}
\hline & $\begin{array}{l}\text { Vote for } \\
\text { League }\end{array}$ & $\begin{array}{l}\text { Vote for other } \\
\text { centre-right } \\
\text { parties }\end{array}$ & $\begin{array}{l}\text { All } \\
\text { voters }\end{array}$ \\
\hline The government should intervene in the economy & 54.5 & 57.8 & 69.4 \\
In favour (\%) (6-10) & 6.2 & 6.3 & 6.9 \\
Average score (on a scale of 0-10) & & & \\
Taxation should be lowered even at the cost of & 52.5 & 51.9 & 26.9 \\
$\quad$ reducing public services & 6.5 & 6.3 & 5.1 \\
In favour (6-10) & $(273)$ & $(199)$ & $(1850)$ \\
Average score (0-10) & & &
\end{tabular}

Source: Itanes-SWG, panel 2013-15.

social costs with a new form of protectionism for Italians alone. The League is in good company here across the continent, where its closest international allies like FN/RN have long militated for national preferentialism. Such a position is no doubt effective in providing a solid identity basis for political action but proves unsuitable when it comes to going international. The great drawback of national chauvinism is that, by its very nature, it is ill-equipped for striking up alliances, taking joint decisions or producing esprit de corps within its own ranks.

\section{The League in perspective: is a Eurosceptical national party a solution for a regional issue?}

After having put paid to the interlude of government with Movimento 5 Stelle, Salvini's League has been confined to the opposition. Although out of the national limelight, it is still credited with a great following and rated the first party in the land. From this perspective, one can but speculate where this project of the leader's is leading: viz. once again to build up a party that is both a protest movement and a governing force, inside yet against the institutions, able to outstrip the conservatives and launch the challenge of sovereignism Europe-wide. By way of answering, let us begin from the national arena and then go into the niceties of the international position.

On the home front, then, Salvini's party faces a dual challenge, both inside the party and in relation to the other political competitors. Within the League the vertical structure he imparted gave Salvini great visibility in the media. But with the demise of the coalition government, the scheduled rise to sole command of the country has met with a considerable reverse. The prolonged absence from decision-making and uncertainty as to the timing of the next ballot have once again sparked off internal tension among party members; and part of Salvini's difficulty in responding is that he can no longer count 
on support from the hard core of activists, which has dwindled over the years and is less solidly entrenched across the country. Add to this the effect of the health crisis that has blown up since March 2020. The two northern regions under League administration - Lombardy and Venetia - have handled the Covid-19 emergency with differing degrees of effectiveness: Lombardy has performed poorly, Venetia much better. This has rekindled smouldering conflict among party factions and thrown up schemes alternative to Salvini and more on the old federalist League model (in the present instance represented by the Venetia governor, Luca Zaia, his political rival).

The other challenge concerns relations with (former) allies. After the coalition government with M5s collapsed, the chief dilemma has been relations with Forza Italia. Outside so-called Padania, the League is still conditioned by the influential presence of Silvio Berlusconi in regions where Salvini's party cannot go it alone (the South). Then there is right-wing competition from Brothers of Italy (FdI), the post-fascist formation led by Giorgia Meloni (shades of another woman, Le Pen). FdI holds the advantage over the League in embodying the traditional or classic version of the Right which is better placed to handle the North-South cleavage and intercept those southern voters who are as yet unsure of the League's programme. Besides its competitive edge in the Italian South, FdI is a challenge to the League over the role of the State in terms of policies, symbols and foreign policy (for example, it has adopted a less cowed stance towards Russia and is more open to relations with Donald Trump).

The national outcome be what it may, the League's future prospects hang very much on international relations. For all the sound and fury of past years and the anti-European back-up guaranteed by the US and British governments, the poor performance of the sovereigntist bloc at the 2019 European elections was a grave setback to its ambitions of storming the Union institutions. Though the League and the FN/RN did well in their respective countries, the populist radical right as a whole had its wings clipped in terms of lobbying and influence in Brussels. This was partly due to inner divisions over certain key issues. There are differences, for example, on public spending, with southern Europeans favouring expansion policies, while the northern are more inclined towards austerity. On immigration there is friction with the Hungarian leader Orbán, who is against reforming the Treaty of Dublin which obliges refugees to stay in their Mediterranean countries of arrival. Lastly, problems have arisen over relations with Putin: the League is favourable, but many East European formations are dead set against. The overall conclusion must be that the sovereigntist internationale has no shared European programme, but is made up of individual national projects agreeing on one objective: to use nationalism to destabilise, replace or transform the various conservative parties, with each sovereigntist branch pursuing its own political interest at home rather than creating a European front. But even this broad goal is by no means certain if one looks at the tragic turn of events in 2020. The health and economic emergency caused by Covid-19 has further 


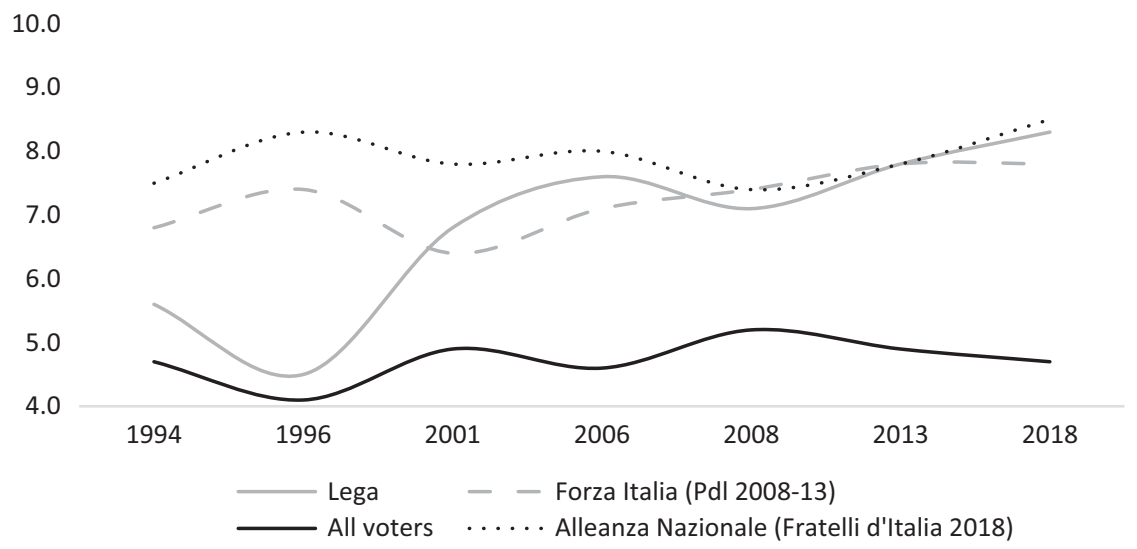

Figure 6.1 Left-right self-placement, voters for the League, for other centre-right parties and all voters. Period 1994-2018.

Note: Left-right score (scale 0-10) on Y-axe.

Source: Itanes.

weakened the challenger parties who are absent from the control room and unable to voice proposals in the European Parliament. Fear of the pandemic has made secondary the issues of the traditional battle-cries of the populist radical right, such as immigration scaremongering. The extraordinary injection of public funds earmarked for rebooting national economies has come to the assistance of national governments, cancelling austerity measures, especially in Mediterranean countries where the populists were on the rise. Still, it is true that the as yet unforeseeable effects of the crisis will multiply conflict and cause political, social and economic destabilisation. And the challenger parties are ready to pounce on any opportunity that may come their way.

\section{Notes}

1 Gianluca Passarelli and Dario Tuorto, Lega \& Padania. Storie e luoghi delle camicie verdi, (il Mulino 2012).

2 Seymour M. Lipset and Stein Rokkan, 'Cleavage Structures, Party System and Voter alignments: An Introduction', in Seymour and Rokkan (eds), Party System and Voter Alignments: Cross National Perspective, (Free Press 1967), 1-64.

3 Ilvo Diamanti, Bianco, rosso, verde e ... azzurro, (il Mulino 2003).

4 Roberto Biorcio, La Padania promessa, (Il Saggiatore 1997).

5 Gianluca Passarelli and Dario Tuorto, 'La Lega Nord oltre il Po', (2009), 58, il Mulino, 4, 663-670.

6 Lieven De Winter and Huri Türsan (eds), Regionalist Parties in Europe, (Routledge 1998).

7 Filippo Tronconi, I partiti etnoregionalisti. La politica dell'identità territoriale in Europa Occidentale, (il Mulino 2009). 
8 Nicolò Conti and Luca Verzichelli, 'La dimensione europea del discorso politico in Italia: un'analisi diacronica delle preferenze partitiche (1950-2001)', in Maurizio Cotta, Pierangelo Isernia and Luca Verzichelli (eds), L'Europa in Italia. Élite, opinione pubblica e decisioni, (il Mulino 2005), 61-116.

9 Paolo Bellucci, 'La reazione dell'élite politica italiana di fronte all'integrazione europea alla fine degli anni 90', in ibid., 171-222.

10 Gianluca Passarelli, 'Extreme right parties in Western Europe: the Case of the Italian Northern League', (2013), 18, Journal of Modern Italian Studies, 1, 53-71.

11 Gianluca Passarelli and Dario Tuorto, 'The Five Star Movement: purely a matter of protest? The rise of a new party between political discontent and reasoned voting', (2018), 24, Party Politics, 2, 129-140.

12 Piero Ignazi, Extreme Right Parties in Western Europe, (Oxford University Press 2003).

13 Hanspeter Kriesi and Takis S Pappas (eds) European Populism in the Shadows of the Great Recession, (Ecpr Press 2016); Loris Zanatta, Il populismo, (Carocci 2013); Cas Mudde, Populist Radical Right Parties in Europe, (Cambridge University Press 2007).

14 Manuela Caiani, 'Le grandi contraddizioni della destra populista', (2014), 63, il Mulino, 3, 450-458.

15 Oesch D, 'Explaining Workers' Support for Right-Wing Populist Parties in Western Europe: Evidence from Austria, Belgium, France, Norway, and Switzerland', (2008), 29, International Political Science Review, 3, 349-373.

16 Gianluca Passarelli and Dario Tuorto, La Lega di Salvini. Estrema destra di governo, (il Mulino 2018).

17 Fabio Serricchio, Gli italiani, l'Europa e la crisi, (Giappichelli 2018).

18 Bertjan Verbeek, AndrejZaslove and Mathijs Rooduijn, 'Italian Populism: Toppling and Re-Building the Party System Twice', in Andrej Zaslove and Steven B. Wolinetz (eds), Absorbing the Blow: Populist Parties and their Impact on Parties and Party Systems, (Rowman \& Littlefield 2018), 197-222.

19 Marco Brunazzo and Mark Gilbert, 'Insurgents against Brussels: Euroscepticism and the Right-Wing Populist Turn of the Lega Nord since 2013', (2017), 22, Journal of Modern Italian Studies, 624. 


\title{
7 English nationalism and its role in building support for Brexit
}

\author{
The case of UKIP and the Brexit Party
}

\author{
Marcin Galent
}

\section{Some peculiarities of British nationhood}

The analysis of the contemporary transformation of British national identities is difficult for two main reasons. The first is that, in fact, we are dealing with four separate nations that are part of the state, plus the 'fifth nation', i.e. British national identity, which is in a sense an amalgamation of all four, i.e. an identity mixed from these four national components and going beyond their simple aggregate and constituting a separate, additional identification level. It is generally highlighted that this British level consists of Protestantism, involvement in building the British empire, British economic ties and a shared memory of conflicts with the countries of continental Europe. This, of course, does not put the British people in an exceptional position, as many federal states have a very similar situation. However, what is an additional problem is the lack of a written constitution that would regulate relations between the different nations and collective identities, even in the most rudimentary formal and legal sense. Indeed, what is clearly described in other countries in one fundamental document, in the case of Great Britain is very often recognised by the law of custom, tradition, the unwritten contract, or dispersed in numerous legislative acts, not always consistent and cohesive. Hence the continuing validity of the diagnosis by Benjamin Disraeli, who noted that: 'England is not governed by logic, but by Parliament'. Such a situation did not give rise to special problems as long as British identity had a hegemonic status and did not collide significantly with lower-level identities. However, in the last few decades, this state of relative syntony began to seriously disintegrate. ${ }^{1}$

For a long time, reflections on British national identity were rather fragmentary and causal, remaining slightly on the sidelines of research even in the work of such eminent British theorists of the second half of the 20th century nationalism as Benedict Anderson, Ernest Gellner, Eric Hobsbawm, Elie Kedourie or Anthony D. Smith. This was for at least two main reasons.

First of all, this was because it was a derivative of English and British imperialism, which at its peak subjected a quarter of the world's territory to the British monarchy along with a similar proportion of the global

DOI: $10.4324 / 9781003226123-10$ 
population. Within the British empire, the ancient Roman principle of Civis Britannicus Sum was adopted, which meant that in legal terms every subject of the Monarch had equal rights, and thus theoretically belonged to the body politic of Britain. This idea was also upheld after the empire broke up. The first British Citizenship Act, adopted in 1948, granted it to all inhabitants of the countries of the former British colonies, and formally everyone who wished to do so had the full right to come to Britain, without hindrance, to settle, work, and exercise their electoral and other rights on equal terms with the English, Scottish, Welsh and Irish people who had lived in the United Kingdom for generations. Until 1981, between 600 and 800 million people worldwide had nominal British citizenship, although after 1962 it entailed fewer rights. This state of affairs meant that there was a constant tension within the identity, which did not always produce the desired results. On the one hand, such tension allows for the existence of a sense of unity and community that goes beyond particular identities. However, on the other hand, these particular identities can win and where there used to be an understated symbolic border, there can be a desire to transform the cultural border into a political one. A similar thesis was formulated by Robert Young in his work The Idea of English Ethnicity, in which he argues that Englishness had to remain open not only to neighbouring Celtic cultures, but as the empire grew, to the archipelagos of socio-cultural worlds from almost every latitude. ${ }^{2}$ Although the thesis on the exceptional openness of the English collective identity is true, I do not believe that English identity was able to be so flexible that it could be used to bring together the inhabitants of the empire. This was partly because it was too closely linked to the ethno-cultural components, and partly because it would have been treated as an overly obvious expression of English interests, which in the United Kingdom also had to take into account the material and symbolic interests of the Scottish partner. Therefore, it was necessary to build a form of intermediary between Englishness and other national and ethnic identities. Following the union of Scottish and English identity, British identity became precisely such an identity. Hence came the British empire and then the British Commonwealth of Nations, from which the word British, but not the character, was removed in 1949.

The British identity as an imperial and post-imperial feature played a role for the English and still does, the so-called 'empty signifier', i.e. a mechanism allowing the building of an imaginary community in a symbolic dimension. According to Ernest Laclou, such an empty signifier can never be completely filled with symbolic content, because no symbolic set can fully and permanently obscure the lack of social unity. ${ }^{3}$ Symbols evolve and transform in order to maintain the ability to represent the community. They have to adapt to new contexts in order to confirm a sense of unity under fundamentally different conditions. Sometimes certain symbols wear out, their power fades and then there is a need to complete the symbolic universe. However, this addition never closes the empty signifier in its entirety. Instead, it is able to take its place in front of other, rival symbols and thus reflect and influence the 
dominant power relations in society. In this way, there is a constant struggle for a symbolic hegemony in which rival symbolic models of the world try to overtake their competitors in order to fill the central symbolic field and create the dominant imaginarium. ${ }^{4}$

The British national flag is a good example of this mechanism. When a Scotsman looks at it, he sees above all the national symbol closest to him, the ancient national flag with the cross of St Andrew. For an Irishman from Ulster, the Scottish flag goes to the background and St Patrick's cross, the national flag of Northern Ireland, comes to the fore. The Englishman of course takes what is closest to him from the Union Jack, namely the cross of St George, which is the national flag of the English. The British flag lacks Welsh symbolism, which reflects the power relations within the United Kingdom. Wales did not have the status of a separate kingdom during the unification as it had been already absorbed into England with the status of a principality. This does not mean that certain elements of Welsh symbolism were not incorporated into the symbolic universe of England and then Britain. The red rose, unicorn, leek, clover, thistle or lion are the national symbols of the four British nations in the British coat of arms and wherever Britain is symbolically represented. Another, even broader symbol associated with Britishness is the monarchy. The image of Queen Elizabeth II can be found on banknotes and coins not only in Britain, but everywhere she is still considered the head of state, e.g. Canada, Australia, New Zealand, Jamaica and eleven other countries. This is not just a matter of symbolic representation. These countries still have the right to veto changes in certain areas of the United Kingdom, and representatives of their governments sit on the Royal Privy Council.

Today we are dealing with a process of disintegrating British identity which can easily be observed in the symbolic sphere as well. While until the end of the 1980s the British flag was a clear manifestation of English patriotism and nationalism, in the 1990s there was a fundamental change in this respect. The British Union Jack was no longer treated as an overarching symbol of the English political community. As the national consciousness of the countries on the Celtic outskirts grew, the self-awareness of English national identity began to grow too. This is reflected in the popularisation of English national symbolism. It occurred at first in nationalist and extreme right-wing circles, but with time it became more popular. In the 21 st century, we can already observe a very clear distance between identification with the English flag, i.e. the red cross on a white background, representing the patron saint of England, St George, and the Union Jack. The British flag is treated rather as a state and royal flag, while the flag of St George is treated as primarily the English national flag. Thus, in the last three decades we have been dealing with the transformation of national identity in England from a state-citizenship model to an increasingly ethnic model, in which a common origin, to be read as being white and born in England, becomes the most important identity criterion. The British flag is more a symbol of British identity, i.e. one that includes four British nations plus immigrants and ethnic minorities. In this 
sense, it is a symbol of a political bond, recognising the ethnic and cultural pluralism of the national community. The English flag, on the other hand, has become a symbol of exclusiveness, an identity based on the common history, culture and origin of the dominant ethnic group, i.e. white English people.

The second reason why Britishness was not mentioned enough was that the British identity enjoyed the privilege that generally accompanies ideologies at the peak of their effectiveness in influencing reality, when it becomes universal. This is due to the effective processes of naturalisation and dissimulation, which made Britishness a natural state of the world, self-understood and therefore escaping social self-reflection. As a result, Britishness was transparent and had a hegemonic status. Everything that was different, strange and noticeable could be described and studied. If someone referred to the problem of Britishness, they were charged with endangering things because only someone 'foreign' could ask questions that betrayed the lack of internalisation of the key identity elements. Just like the white colour of the skin, which for centuries was not a colour, it was a reference point for other colours like black, brown or yellow. The discovery that white people also possess a skin colour was not accepted in the Anglo-American academic world until the end of the 20th century, before which white was transparent, clear and understandable by itself. People of colour were people of any colour other than white. Its naturalness did not raise special doubts, on the contrary, it often served to establish racial hierarchies.

The same was true of Britishness. Therefore, British social and cultural anthropology studied races, peoples and cultures all over the world, but the point of reference was in the metropolis. It was also the centre of power. The British identity was built largely on power and wealth. As a result, British national identity easily embraced other nations, religions and even civilisations. The condition was to have the power or wealth to open the most important doors in Westminster. And the sources of power and wealth have been constantly changing in recent centuries. The traditional land-based aristocracy was joined by local bourgeoisie, maharajas, colonial-enriched nabobs, owners of plantations in West India and finally industrialists in the 19th century. At the royal court, anyone who contributed to the power and wealth of the empire was welcome. Whether it was an Englishman, a Scotsman, a Welshman, an Irishman, a Jew or a Sikh wasn't the first question. In the British Parliament, not only the indigenous people of Great Britain and Ireland were to be found in the 19th century, but also Jews and Hindus. In such a multicultural and cosmopolitan environment, clearly identifying differences was definitely not conducive to building political solidarity or the economic prosperity of relatively open elites. ${ }^{5}$

The Scottish nationalism theorist, McCrone, even recognised that British national identity was not educated as a nation-state, but as a state-nation. ${ }^{6}$ This means that in the formation of a sense of national belonging, ethnic factors played a much smaller role than in other nation states; civic factors played a much more important role, and in addition, a nation imagined in 
this way was embraced by the overriding buckle of loyalty to the state. This open aspect of British identity is still maintained. In the 21st century, it is less related to external expansion and efforts to maintain ties with former colonies. Much more important is the need to maintain elementary cohesion in a multi-faith, multiracial and multicultural society. The most important British values defined during the period of David Cameron's reign, which every British school has had to teach from 2014, are rather difficult to consider as a symbolic ethnic border. Democracy, rule of law, individual liberties, mutual respect and tolerance, could also be a catalogue of the values of many supranational institutions, especially in Europe. However, this is precisely what it was all about, in order to create the best possible framework for diversity in unity, to save Britain from political disintegration and/or to transform it into segregated parallel communities. ${ }^{7}$ The conviction that British society had become too diverse has ceased to be the view of the extreme right, all the more so as the social geography of poverty and exclusion, which increasingly began to include the white working class, began to change at the end of the 20th century. ${ }^{8}$

Therefore, in such a dynamic and changing world, it was difficult to treat Britishness as a precisely identifiable ideology of a precisely identified territory, with a clearly identifiable culture and population. The boundaries of national identities were thus long, fuzzy, ambiguous, contextual and dynamic. Benedict Anderson claimed that such conditions caused Britishness to be long treated as a collection of dispersed and separated colloquial prejudices and taboos. ${ }^{9}$ Therefore, in cultural as well as legal, political and economic terms, the boundaries of British identity were much more blurred and intuitive than those of other European nation states. ${ }^{10}$ In the British tradition of common law, where pragmatism and common sense meant more than the abstract principles and rules imposed by the centralised state, these borders were subject to constant renegotiation, devaluation and revaluation. This process has continued to this day, as is perfectly illustrated by the real example of the political and legal struggle to maintain the Chagos Islands in the Indian Ocean, including the non-recognition of the judgment of the International Court of Justice in The Hague, ${ }^{11}$ or the offer made by Prime Minister Boris Johnson ${ }^{12}$ in 2020 to admit three million Hong Kong residents who still retain British National (Overseas) status under the Nationality Act of 1981. In more general terms, attempts are made to restore this volatile nature of the British border by renewing ties with countries associated with the Commonwealth of Nations. This is a return to those elements of the British imaginarium that seemed to have gone away for good with the humiliating defeat in Suez in 1956. The introduction of such slogans as 'Global Britain' and especially 'Empire 2.0' to the political and public discourse means a return to the creation of a symbolic model of the world in which the British metropolis lay at the centre of the world. ${ }^{13}$ Perhaps it was an ideological alternative created for Brexit, maybe the British will actually come closer to their former compatriots. For the time being, the sustainability of the Union has been questioned. 


\section{The break-up of Britain}

The first serious fractures in British identity date back at least to the end of the 1970s, when Tom Nairn, a Scottish nationalism theoretician with Marxist inclinations, published a collection of essays with the notable title The Break-Up of Britain. ${ }^{14}$ Apart from complex empirical analyses and theoretically sophisticated generalisations, his most important theses can be reduced to a few essential points. First, Nairn claimed that the British identity had developed mainly on the basis of English society, culture and state. Secondly, the English achieved centuries of state expansion, during which they subjugated various peoples, but in doing so, they allowed them considerable freedom in sustaining local social institutions and cultural specifics. Thirdly, the industrial revolution that took place in Great Britain was intertwined with economic and colonial expansion, which in the British nation-building process resulted in a class agreement crossing ethnic borders, which along with the co-opting of the working class, resulted in the state avoiding the formation of modern national identities through revolutionary upheaval and national mobilisation. However, with the cessation of political and economic expansion in the 20th century, the foundations of the British patriotism promoted by the state shrank, which resulted in the revival of a sense of national separateness in peripheral nations, the so-called Celtic fringe.

Let us take Scotland as an example. While Scotland, during the demographic explosion of the 19th and early 20th centuries, was able to benefit from the channels of mobility provided by imperial institutions covering a quarter of the earth's surface, after the Second World War and the period of decolonisation, such opportunities simply disappeared. The same was true of Scotland's economic structure, which went through a period of exceptionally effective competition mainly due to the fact that its industry was the economic back-up not only for the UK as a whole, but for the whole empire. After Britain lost its global influence, first following decolonisation and then by joining the European Community and restricting trade with the Commonwealth of Nations, Scottish industry ceased to receive lucrative orders and began to collapse. Finally, in the 1970s, rich oil and gas deposits were discovered in the North Sea. If Scotland were an independent country, all these deposits would be within Scottish territory and the Scots would profit from them. However, within the UK, the territory belongs to the whole country and it is up to the elite of Westminster and the City to decide who benefits from it, as well as what benefits it brings. It made no sense to stay in the Union with the English because the benefits of a common economy had disappeared and without independence there are no proper channels of social advancement. The highest positions were mostly in London.

\section{Devolution}

The British government's response to the national rebirth was to initiate the process of devolution, i.e. to agree to the transfer of part of the power from 
the centre to individual countries in the UK. In 1979, this idea did not find sufficient support among the Scots and Welsh people for the idea of self-government, and therefore devolution failed in a referendum. It was only with the return of the Labour Party that the idea reappeared. The government, headed by Tony Blair, held new referendums in 1997, which this time proved to be successful for the supporters of self-government in Scotland, Wales and Northern Ireland and which resulted in the creation of the Scottish Parliament, the Assembly of Wales and the Northern Ireland Assembly in 1999. ${ }^{15}$ This transformed the United Kingdom from a unitary state into a 'multi-union state'. ${ }^{16}$ The plurality is not insignificant here because it reflects the most characteristic feature of devolution, namely its asymmetric nature. ${ }^{17}$ This asymmetry lies in the unequal range of powers granted to the legislators and enforcers of the four constituent countries of the United Kingdom. Most power was given to the Scots, slightly less to the Irish and Welsh, while the English were not given any at all. The asymmetric nature of devolution became to a large extent the source of the reactive growth of English nationalism, especially when it turned out that this asymmetry brought a deterioration in their standard of living in comparison with other Union nations.

The development of national tendencies in the countries of the Celtic fringe has also contributed to an awareness of distinctiveness among the English themselves. Already in the early 1990s, research indicated that more than $60 \%$ of the English people stated that being British was the most important national identification, and only a few more than $30 \%$ claimed to be mostly Englishmen. In 2011, these proportions changed fundamentally. Only about $40 \%$ chose Britishness, while Englishness, as the most important national identity, was indicated by almost 50 percent. ${ }^{18}$ This scale of changes was also reflected in the growing politicisation of Englishness. It is manifested itself mainly in the crystallisation of public debate on the political and institutional consequences of strengthening English identity and the growing competition between political parties over which one would present itself to voters as the best representative of English interests and aspirations. A tangible effect of this politicisation of the English identity has been a sudden increase in support for a solution to a problem still referred to in the 1970s as the West Lothian Question. The point is that Scotland, Wales and Northern Ireland have their own representatives in the Parliament at Westminster, who have full voting rights on all matters, whether they concern the whole kingdom or just matters relating to England. However, the English are not represented in the legislative bodies of Edinburgh, Cardiff and Belfast and therefore their views are not relevant to the legislation adopted there. The lack of a separate legislature for England means that matters for the English are decided by people who neither live in England, thus are not subject to that law, nor are they elected by the English, hence they are deprived of democratic legitimacy.

Meanwhile, these matters have become particularly intense in recent years. From 2007 to 2012, the number of responses among the English has doubled, indicating that British governance has deteriorated as a result of devolution. 
While in 2007 this solution still enjoyed relative support, in 2012 as many as $35 \%$ of the English surveyed stated that it was worse in this respect than in the times of a strictly unitarian state, i.e. before 1999. These opinions go hand-in-hand with a critical assessment of the impact of devolution on England. Since 2000, the number of Englishmen claiming that Scotland is getting more than it deserves has also increased by almost $100 \%$ by 2012 , and $45 \%$ of them believe so. At the same time, $40 \%$ of the English claim that England is disadvantaged by this arrangement and gets less than it deserves. The majority of the English think that the Scottish economy benefits more from the EU than the English economy, with less than $25 \%$ believing that each economy benefits equally. ${ }^{19}$

As a result of devolution, individual devolved governments make autonomous choices in very vulnerable areas. The consequence of these choices is that some solutions and goals are preferred over others, which leads to qualitative differences in the implemented public policies, and thus to a clear differentiation of the Scottish welfare state model. It is worth recalling that these differences affected three extremely sensitive areas of social policy: care for the elderly, payments for higher education and the role of the state in shaping housing policy. The Scottish welfare state model is clearly moving towards a social democratic model, typical of the Scandinavian countries. These 20 years of devolution have clearly shown that Scottish and English priorities differ. The Scottish National Party has consistently protected those social achievements that were introduced under the Labour Party and introduced new ones. Today, every Scot is entitled to free old age care, is exempt from university fees and is protected from the most drastic consequences of the austerity housing policy. Unlike England, the Scottish government has provided further funding for young people's rents and protected residents from the hated 'bedroom tax' in the south. The Scots were also the first to abolish the 'right to buy' programme in the UK, making it a priority again to rebuild the overall housing stock available and keep it relatively cheap.

However, these changes are so deep and dynamic that there is a lack of adequate monitoring studies. Therefore, this is a largely untransparent and uncertain situation. The British do not see whether Scotland's social policy is simply a reflection of the ideology of their ruling party, which has the main goal of building an efficient welfare state and egalitarian society. England has been ruled by the Tories for a decade, who have made the idea of egalitarianism and a welfare state their main opponent. They value individualism, the free market and competition more. Hence the fundamental question of whether the Scottish social model is simply a political choice and would be feasible in the same form in England, or whether Scotland enjoys a privileged position in the Union, thanks to which it receives proportionally more money than other nations? In 2009, the House of Lord Select Committee on the Barnett Formula recommended a change in the way the Union is funded..$^{20}$ Joel Barnett himself, the founder of a mechanism for financing devolution, admitted that 'It is unfair and it should be stopped. It is a mistake'. ${ }^{21}$ 
The whole mechanism of allocating money within the Union is so complex and indecipherable that it is in practice not the subject of analysis in public discourse. Almost no one can explain what costs the Scots have to pay in exchange for maintaining these three pro-social solutions, and why they can afford it - nor can England and the English. In the lack of access to objective knowledge and transparency of budgetary arrangements, the decline in confidence, increased suspicion and a sense of deprivation have contributed to the politicisation of English identity.

\section{English backlash}

Therefore, it is not surprising that in the second decade of the 21st century, public support in England started to grow rapidly for eliminating these asymmetries caused by devolution. In 2014, the electorate of every major political party in England was dominated by a vote that Scotland should have its privileged position taken away and bring spending levels down to the UK average. In the case of Labour Party voters, 50\% expressed support for such a policy, among the supporters of the Liberal Democrats the support was slightly higher at $56 \%$, while among the supporters of the Conservative Party and the UKIP electorate such support was $69 \%$ and $70 \%$ respectively, i.e. an overwhelming majority. ${ }^{22}$

The overwhelming majority of English people also began to contest the constitutional solutions that had been adopted so far. No fewer than $80 \%$ of the English people were in favour of full financial responsibility for Scotland, i.e. the liquidation of the Barnett formula. On the other hand, as many as $79 \%$ supported the proposal to exclude Scottish members of parliament in Westminster from voting on matters concerning only England, a constitutional solution called the English Votes for English Laws. ${ }^{23}$ Public opinion surveys very clearly reflected the conviction of the English people that they lacked a political representation which cares for their interests above all. Two years before the Brexit referendum, the greatest number of Englishmen would have wanted a special English parliament, particularly among those who identified themselves more as English than as British. This support for the establishment of their own parliament was double that of those who identified themselves as British. This feeling of a lack of subjectivity among the English was also shown by the data concerning the assessment of the size of the impact by various institutions of power on everyday life. Only $6 \%$ of those in Wales and 4\% in Scotland indicated the European Union, while 26\% of those living in England did so. 2014 also saw an extremely strong correlation between English identity and Euroscepticism, as well as a desire to vote to leave the EU. Among those in England who identified as British, 42\% considered the EU to be a 'good thing' and $45 \%$ wanted to vote to stay in the EU. In the case of Englishmen who preferred their ethnic identity, only $23 \%$ considered the EU to be a 'good thing' and only $26 \%$ of them voted in a referendum to stay in the EU. ${ }^{24}$ 
In response to these trends, in the autumn of 2015 David Cameron's government sent a draft law to the House of Commons which planned to exclude MPs not representing English constituencies from voting on purely English issues. The draft began as an ordinary parliamentary procedure and if it had not been for the announcement of a referendum on further UK membership of the European Union, it would have further complicated institutional, legal and identity relations in the UK. However, there is much to suggest that the Brexit issue pushed the UK reform project into the background. Perhaps Brexit has absorbed enough of the energy and emotions of English nationalists to avoid returning to it.

But the rise of English nationalism had, in addition to dissatisfaction with devolution, a second source: an unwillingness to be a member of the European Union and in particular the consequence of membership which was associated with the free movement of people. ${ }^{25}$ Since the EU's enlargement to include the countries of central-eastern Europe, around 500,000 people a year had begun to immigrate to Great Britain. With 200,000 leaving the UK each year, this meant that about 300,000 people settled in the islands each year, the vast majority of them in England. Never before had Britain experienced such a scale of immigration over such a short period of time, and although until 2008 it was rather seen as a desirable strengthening of the British economy, these assessments changed dramatically after the outbreak of the financial crisis. This change did not occur so much in the opinions of economic experts as in social attitudes, especially among Englishmen from outside the major metropolitan centres. However, unlike in the 1960s, when the British government initiated many support programmes for those regions where the presence of immigrants was associated with increased pressure on local public services, this time neither the British government nor Brussels decided to intervene, although experts warned that such a laissez-faire policy was unsustainable. ${ }^{26}$

Eric Kaufmann claims that the rapid change in the socio-cultural environment has never been welcomed positively, so even without the Great Recession, relations between immigrants and the English would have become increasingly tense. ${ }^{27}$ This was particularly true in small-town and rural environments, where the presence of immigrants was previously either rare or seasonal. ${ }^{28}$ After 2004, immigrants seemed to reach the most distant corners of England and in many places their presence contributed to real flexibility and further labour market deregulation. ${ }^{29}$ Reliance on workers employed by employment agencies often meant bringing them directly from their countries of origin by plane. This obviously had a negative impact on the employment of local residents. This was firstly, because the wages offered were rarely higher than the minimum wage, and secondly, because a cultural mechanism is often created to discourage members of the host society from working in the same sector as immigrants in societies with rapid levels of immigration. This is a rather universal phenomenon and related to the fact that every profession and job has a prestige dimension beyond the financial one. Work is not only 
a source of money, but also an important element in constructing identity and one's place in the social hierarchy, which is sometimes a more important source of value and self-esteem than money. Many professions or jobs lose their prestige because they are defined as immigrant ones. Moreover, as many British researchers have shown, over-reliance on immigrants to do certain jobs has often led to worsening working conditions and attempts to play off the image of 'hard-working immigrants' against alleged local freeloaders. ${ }^{30}$ The massive degradation of labour standards has not only affected niche economic sectors such as seasonal agriculture, where civilised standards are difficult to control and enforce. ${ }^{31}$ Instead of being associated with supporting sectors that have been most in decline in the last decade, immigration has become better known for transforming businesses that are recognisable British high-street names into labour camps based on exploitation. One of the press titles describing such a reality invited readers to read a report from a day in the life of a 'gulag'. ${ }^{32}$

Low wages and the decline in employment prestige have often resulted in decisions to relocate to where the jobs are, namely to London. However, the natural process of internal migration, which for decades was an effective mechanism of social mobility in the 21 st century, lost its effectiveness. The sell-off of a huge number of council flats in the 1980s and 1990s, followed by the full marketisation of residential construction, resulted in a sharp housing deficit and a rapid increase in purchase and rental prices. ${ }^{33}$ The cost of living in this respect became too high even for professions previously considered to ensure a middle-class standard of living. Moving to London no longer guaranteed an increase in living standards and a sense of social advancement. ${ }^{34}$ With the increased fertility rate of immigrant families, ethnic minorities were more likely than the English to count on the allocation of social housing, waiting times for which have stretched from a few to a dozen or even several dozen years of waiting anyway. ${ }^{35}$ For many English people, this situation created a sense of injustice. In their opinion, England was built by generations of Englishmen, a historic nation whose members should have some form of preference for those who had settled a few years earlier. ${ }^{36}$ This sense of injustice in equating the contribution to the common good of England between those who have worked for generations for the prosperity of the country and those who have lived in England for a short time, often without emotional attachment or willingness to make sacrifices for it, has contributed to a stronger crystallisation of the boundary between the so-called 'somewherers', i.e. people attached and deeply loyal to 'here and now', and 'anywherers', i.e. those who are mobile, ready to change places to live and work, with flexible and contextual weak loyalties. ${ }^{37}$

It seems that the winner of this competition for the title of the best representative of English aspirations was Nigel Farage. The leader of UKIP and later the Brexit Party managed to convince those most dissatisfied with the conditions of England's participation in the two unions, the British and European, to support his populist programme against the British and 
European elites. All opinion surveys show that those least satisfied with the devolution process are the English, and the particular ones who prefer an English over British identification. In the second decade of the 21st century, a belief began to spread among the English that they had been left on their own and that there was a lack of a political representation that was based primarily on the English interest. In 2011, in a survey of public opinion, the most frequently chosen answer to the question of which political party best pursues the interests of England was 'none of the above'. The Labour Party came second, followed by the Conservative Party. In the case of the Liberal Democrats, the coalition partner of the Tories, this recognition barely reached $5 \%$. The situation changed only in 2013, when most of the respondents indicated UKIP as the party best pursuing the interests of English. The situation was similar with regard to politicians. Nigel Farage is considered to be the best representative of England's interests, followed by the answer 'none of the above' and only much further on by Prime Minister David Cameron and the then opposition leader, Ed Milliband. ${ }^{38}$

The referendum on Brexit was a merger of two sources of dissatisfaction. Since neither the Labour Party nor Coalition governments were able to make significant changes, the conviction emerged, quite rationally, that external restrictions were the reason for this impossibility. The organisation of a referendum in 2016 gave frustrated voters the opportunity to oppose everything that they had previously been dissatisfied with. Nigel Farage and UKIP managed to convince their supporters that English interests were not adequately represented within the UK and were doomed to be permanently marginalised in the European Union. Contrary to UKIP's name, Nigel Farage did everything he could to identify himself with the everyday nonmetropolitan English person and thus attract their support. A cigarette, a glass of beer in the pub, an old-fashioned coat and an anorak were symbols that did not refer to Britishness, but introduced the kind of class props typical of the English provincial. Mobilising the emotions of the English proved to be effective enough to free Britain from the European yoke. Paradoxically, this may mean that devolution will survive and so too will the UK. St George may have killed the EU dragon, but emotions have fallen and now it is time to return to routine and take responsibility for the shape of things to come, free from European influence.

The origins of the rise of negative attitudes amongst the English towards devolution and the Scots are not irrational, and still the vast majority of the English people are in favour of maintaining the United Kingdom. There were also many reasons to rationally criticise the principles of the European market, especially the passivity shown by Brussels at the time when the UK became the labour market of last resort for a large part of the European Union in the Eurozone crisis. Modifying the solutions in ways that would remove the causes of social fears is possible and technically probably relatively easy to accomplish. However, today the Union faces a fundamental dilemma. If Westminster takes away the Scots' privileges, i.e. equalises the 
funding with the English, a large part of the frustration fuelling English nationalism is likely to disappear. Such a choice would be almost a clear acceptance of Scottish independence. There is no doubt that today's Scots are much closer to the Scandinavian than the Anglo-Saxon model. Regardless of whether Scotland becomes the second Norway or not, depriving it of its social achievements of the last two decades would definitely tip the scales against support for staying in the Union. Let us recall that the full name of the ruling party is the Conservative and Unionist Party. The Tories would have to radically change their attitude to the Union to risk such a change and thus the break-up of the UK. Therefore, assuming that Westminster wants to extinguish British people's negative views of the current shape of devolution, and thus wants to keep the United Kingdom as a whole, it should introduce reforms in England that will break with the most painful consequences of the neoliberal economic policy initiated by Margaret Thatcher and a decade of austerity introduced after the crisis of 2008.

\section{What next?}

Given the size and intensity of conflict within the Conservative Party in 2016-2019 and the fact that an outsider, Boris Johnson, regarded as an antiestablishment politician who sees himself as a very flexible and ideologically stretched One Nation Tory, has emerged victorious, this is an opportunity to avoid alienating the Scots, while at the same time strengthening the sense among English people that someone has started to take care of their interests. This chance is reinforced by the experience of the recent Covid-19 pandemic, which has created what could be described as a critical juncture. For some time there will be a liminal situation in which the old norms and values cease to apply with their previous force and the new ones have not yet developed. Whether or not the new ones will develop depends on the level of empowerment of the authorities. The rejection of neoliberal dogmas during the pandemic, the announcement of the New Deal and Boris Johnson's promise to invest hundreds of billions of pounds in infrastructure and housing give rise to the idea that there will actually be a paradigmatic change in the relationship between society and economics.

An additional stimulus in this direction may also be the retreat from neoliberal orthodoxy in the European Union. The announcements of major investment programmes, financed by EU-wide joint borrowing for the first time, will undoubtedly be an important point of reference for the British government. The exit from the EU was supposed to give the British people an improvement in their economic situation, especially those who were in the most difficult circumstances. Therefore, it would be extremely difficult to deal with this cognitive dissonance if it turned out that Brexit meant a voluntary relinquishment of this pro-development impulse. It seems that Boris Johnson is aware of this, because during the announcement of his New Deal in Dudley, traditionally a working class and Labour district, he stated that: 'This is a 
Government that is wholly committed not just to defeating coronavirus, but to using this crisis finally to tackle this country's great unresolved challenges of the last three decades', ${ }^{39}$

However, these Roosveltian analogies have been widely criticised for overstating rhetoric over the planned mobilisation of resources. Nevertheless, the public acknowledgement by the head of the Conservative government that Thatcherism and post-Thatcherism in the form of New Labour have failed is unprecedented. The announcement of the creation of further tools for state intervention and the recognition that the state should be the initiator and leader of investments in infrastructure and construction is a return to the economic model of the 1960s. This was a time that was the most important point of reference for the voters who most identified with England and were the most alienated by the lack of active economic and social policy in England. These are mainly elderly people, living outside large metropolitan areas, less educated, whose main interpretative framework of the world is based on a belief that they have been left alone and left behind. Boris Johnson perhaps knows this all too well and identified it, as did his recent direct rival, Jeremy Corbyn. Presenting his New Deal, he admitted that: 'Too many parts of this country have felt left behind, neglected, unloved, as though someone had taken a strategic decision that their fate did not matter as much as the metropolis'. ${ }^{40}$

If the rhetoric is followed by action, and the British government takes up the economic offensive, the English sense of being treated worse than other nations in the Union will also change, which in turn will weaken the determination of English nationalism to revise the constitutional order on which the current Union is based. Perhaps the rise of English nationalism has been consumed by an act of disobedience, as represented by the vote for Brexit. This was expressed as a democratic act of will but was also a vote against the government and almost all public authorities. The political defeat of Nigel Farage and his Brexit Party indicate that English nationalism did not have a long-term national-forming character, but voters rather used the Eurosceptic wave reinforced by the xenophobic policies of the Cameron government and the European migration crisis to relieve their frustration and articulate their dissatisfaction with developments in the country.

\section{Notes}

1 Marcin Galent, 'Brytyjskość - w poszukiwaniu kulturowego spoiwa dla politycznej jedności', in Joanna Kurczewska and Zdzisław Mach (eds), Kultury narodowe $i$ lokalne a polityka, (Instytut Filozofii i Socjologii PAN 2019), 207-209.

2 Robert RJ Young, The Idea of English Ethnicity, (Blackwell Publishing 2008).

3 Ernest Laclau, On Populist Reason, (Verso 2005).

4 Aletta Norval, 'Poststructuralist conceptions of ideology', in Michael Freeden, Lyman Tower Sargent, Marc Stears (eds), The Oxford Handbook of Ideology (Oxford University Press 2005), 162-164. 
5 Lawrence Stone and Jeanne C Fawtier Stone, An Open Elite. England 1540-1880, (Clarendon Press 1995).

6 David McCrone, 'Unmasking Britannia: The Rise and Fall of British National Identity', (1997), 3, Nations and Nationalism, 579-596.

7 Ted Cantle, Community Cohesion. A New Framework for Race and Diversity, (Palgrave Macmillan 2008).

8 David Goodhart, 'Too Diverse?', (20 February 2004) The Prospect, www. prospectmagazine.co.uk/magazine/too-diverse-david-goodhart-multiculturalismbritain-immigration-globalisation accessed 12 June 2020; Roger Hewitt, White Backlash and Politics of British Multiculturalism, (Cambridge University Press 2005).

9 Benedict Anderson, Imagined Communities. Reflections on the Origin and Spread of Nationalism, (Verso 2016), 32.

10 Robin Cohen, Frontiers of Identity: The British and the Others, (Longman 1994), 20.

11 TJ Coles, Human Wrongs. British Social Policy and Universal Declaration of Human Rights, (iff Books 2018), 15-20.

12 Shibani Mahtani, 'Boris Johnson offers refugee, British path for citizenship for nearly 3 mln Hong Kongers', The Washington Post, (Washington, 3 June 2020), www.washingtonpost.com/world/asia_pacific/boris-johnson-hong-kong-nationalsecurity-law-bno-passport/2020/06/03/3ec6ddf0-a545-11ea-b619-3f9133bbb482_ story.html accessed 7 July 2020.

13 Annebelle Dickson, 'Ex-colonies to UK: Forget Brexit "Empire 2.0", (2018), Politico, www.politico.eu/article/commonwealth-summit-wont-be-empire-2-0-forbrexit-uk/ accessed 28 June 2020.

14 Tom Nairn, The Break-Up of Britain, (Verso 1981).

15 Colin Pilkington, Devolution in Britain Today, (Manchester University Press 2002).

16 Michael Kenny, The Politics of English Nationhood, (Oxford University Press 2016), 40.

17 Marcin Galent, 'Asymetryczna dewolucja w Zjednoczonym Królestwie: Walijczyków droga do autonomii', in Jan Iwanek and Robert Robert (eds) Autonomia terytorialna $w$ perspektywie europejskiej, (Wydawnictwo Adam Marszałek 2014), 38-55.

18 Richard Wyn Jones and others, The Dog that Finally Barked. England as an Emerging Political Community, (Institute for Public Policy Research 2012), 19.

19 Richard Wyn Jones and others, England and Its Two Unions. The Anatomy of a Nation and its Discontents, (Institute for Public Policy Research 2013).

20 House of Lords, 'The Barnett Formula - Select Committee on the Barnett Formula', (2009), https://publications.parliament.uk/pa/ld200809/ldselect/ldbarn ett/139/13903.htm accessed 24 June 2020.

21 Steven Swinfort, 'My funding formula for Scotland is a "terrible mistake", Lord Barnett admits', The Telegraph, (London, 16 September 2014), www.telegraph. co.uk/news/uknews/scottish-independence/11100400/My-funding-formula-forScotland-is-a-terrible-mistake-Lord-Barnett-admits.html accessed 10 July 2020.

22 Charlie Jeffery and others, Taking England Seriously: The New English Politics, (The Future of England Survey 2014), 25.

23 Jones and others, (n 18), 2.

24 Charlie Jeffery and others, Taking England Seriously: The New English Politics, (The Future of England Survey 2014), 28. 
25 Geoffrey Evans and Anand Menon, Brexit and British Politics, (Polity Press 2017), 77.

26 Marcin Galent, 'Towards a New Borderlands in the European Union', in Alicja Szerląg, Justyna Pilarska, Arkadiusz Urbanek (eds), Atomization or Integration? Transborder Aspects of Multipedagogy, (Cambridge Scholars Publishing 2016), 31-49.

27 Eric Kauffman and Gareth Harris, Changing Places, (Demos 2014).

28 Jon Burnett, The New Geography of Racism: Peterborough, (Institute of Race Relations 2012).

29 Agnieszka Kubal, Socio-Legal Integration. Polish Post-2004 EU Enlargement Migrants in the United Kingdom, (Ashgate 2012).

30 Robert MacKenzie and Chris Forde, 'The rhetoric of the 'good worker' versus the realities of employers' use and the experiences of migrant workers', (2009), 23, Work, Employment and Society, 1, 142-159.

31 Stephen Armstrong, The New Poverty (Verso 2017). Stuart Tannock, 'Bad attitude? Migrant worker, meat processing and the local unemployed in a peripheral region of the UK', (2013), 22, European Urban and Regional Studies, 4, 416-460.

32 Simon Goodley and Jonathan Ashby, 'A day at the "gulag": what it's like to work at Sports Direct's warehouse', The Guardian, (London, 9 December 2015), www. theguardian.com/business/2015/dec/09/sports-direct-warehouse-work-conditions accessed 6 April 2020.

33 John Boughton, Municipal Dream: The Rise and Fall of Council Housing, (Verso 2018).

34 Anna Minton, Big Capital. Who is London For?, (Penguin 2017).

35 May Bulman, 'UK facing biggest housing shortfall on record with backlog of 4 mln homes, research shows', The Independent, (London, 18 May 2018), www.independent.co.uk/news/uk/home-news/housing-homeless-crisis-homes-a8356646. html accessed 17 March 2020.

36 Robert Ford and Matthew Goodwin, Revolt on the Right: Explaining Support for the Radical Right in Britain, (Routledge 2014).

37 David Goodhart, The Road to Somewhere: The New Tribes Shaping British Politics, (Penguin 2017).

38 Charlie Jeffery and others, Taking England Seriously: The New English Politics, (The Future of England Survey 2014), 28-29.

39 Gordon Rayner, 'Boris Johnson plans a 'Roosveltian New Deal to rebuild Britain', The Daily Telegraph, (London, 29 June 2020), www.telegraph.co.uk/news/2020/ 06/29/boris-johnson-plans-rooseveltian-new-deal-rebuild-britain/ accessed 12 July 2020.

40 Ibid. 


\title{
8 Ally, opponent or means to an end? The role of the European Union in the Catalan independence process
}

\author{
Agnieszka Grzechynka
}

\section{Introduction}

'You know, that's because this is Catalonia, not Spain' - an older man sitting on a bench in front of his house on the outskirts of Barcelona, reached out to point at the Catalan revolutionary flag, fluttering just below his window, along with handwritten letters forming the inscription 'democracy'. This man's statement does not seem surprising in the context of the events of the end of 2017 and beginning of 2018, when the future of Catalonia, as a potentially independent state, became a frequent subject of political disputes and a hot topic discussed by international journalists, political scientists - and politicians in the European Union.

The Spanish Constitution of 1978 ended decades of Franco's authoritarianism, and paved the way for the democratic transformation of this part of the Iberian Peninsula. It not only established a parliamentary monarchy but also a regional system of the state, which became both a key to preserving the richness of its cultural diversity and a source of conflict on the grounds of identity. Residents of several of the 17 regions and two autonomous cities, referring to a historically documented heritage (as well as raising the argument of having a separate language and culture), began to demonstrate a degree of identification which was different from the vision of one common Spanish state.

Catalonia possessed a distinct language (initially a local variant of Latin but formalised at the end of the 11th century), a separate culture and tremendous economic potential which were widely acknowledged. This lead to it obtaining the widest range of permissions which allowed for a significant degree of self-government. By virtue of the Constitution and the Autonomous Statute, Catalans were, however, denied the opportunity to implement their own foreign policy or to grant citizenship while still being obliged to transfer a significant part of their revenue to the central budget.

These reasons, born out of a sense of economic injustice and an arguably stronger one of Catalan identity, led to the birth of catalanism in the 19th century. ${ }^{1}$ This was neither accepted by Spanish society nor granted legal recognition in normative acts but remains a regional political doctrine which is still 
the dominant guideline for nationalist politicians of the region. Growing out of the roots of provincialism, catalanism passed through successive phases of federalism, regionalism and pujolism, ${ }^{2}$ finally reaching the shape of mature political catalanism. Never having had a constant form and ever evolving, it has always maintained a solid foundation shaped by elements characteristic of both nationalist and conservative philosophy, while emphasising the reluctance to use force (which may justify such late direct separatist demands and the choice of direct democracy as a tool for the implementation of contemporary independence postulates), as well as an attachment to the principles of personalistic humanism and the priority given to one's own culture (especially language). In light of recent events, this doctrine seems to have had considerable consequences, becoming both the starting point and the path leading to the implementation of certain decisions of national importance (including the self-recognition of the Catalans as a nation and their struggle for independence).

\section{Catalonia in the history of Europe}

A review of the media coverage and public statements made by numerous nonSpanish decision-makers proves that the Catalan independence movement despite being an important issue in the European political realm - has not been properly analysed and that the idea of the independence of the region itself is treated more as an eccentric, current aspiration of the dominant political party rather than a centuries-long and well-motivated struggle. Before we proceed with further analysis, it is therefore impossible to avoid mentioning that the attempt to define Catalan identity in opposition to the Castilian cultural and political pattern was clearly being made in Catalonia as early as in the Middle Ages. Catalan culture, in contact with the stronger, Castilian one, has always been perceived by the inhabitants of the region as an object of honour and the key to the survival of their identity. This might explain why every attempt to diminish elements of Catalan culture has caused rebellion and united Catalans in resistance to the country's central government.

The breakthrough period was the 17 th century, which was significant not only in the cultural sense, but above all in the political, bringing with it pioneering steps in the struggle for independence. In 1640, the first Catalan uprising broke out (known as the 'Reapers' War') and a year later Pau Claris the then head of the Catalan government - for the first time in the history of the region officially declared Catalan independence under the protectorate of France.

In the following century, both the development of the elements of Catalan culture and the implementation of all political actions were stopped by the decision of the Spanish King, Philip V. Shortly after taking power, on 16 January 1716, he issued the New Order Decree (Nueva Planta), which was to help him implement his vision of centralist rule. The document abolished Catalan political institutions, revoked the privileges previously granted to the 
region, and greatly limited the possibility of using the Catalan language. Yet, contrary to the plans of the Castilian monarchs, the 19th century not only brought the Renaixenca (Catalan Renaissance), but also the political activation of the separatist spirit, which led to two attempts to declare the independence of Catalonia: the first in 1810 (when Catalans gained the support of Napoleon Bonaparte), and the second in 1873 (when an ephemeral and ineffective - attempt was made by the then Catalan deputy, Baldomer Lostau).

An effort to constitute an independent Catalan state was also made twice in the 1930s. On 14 April 1931 - just after the Spanish local elections that resulted in a majority for the radical party - its leader, Francesca Macia, proclaimed the 'Catalan Republic within the federation of Iberian republics' from the balcony of the Palau de la Generalitat de Catalunya. Another attempt three years later - was made by the head of the Catalan government, Lluís Companys, who, on 6 October 1934, shouted: 'Long live Catalonia! Long live the republic! Long live freedom!', announcing the creation of the Republic of Catalonia as part of the Spanish Federation.

Almost five decades of authoritarianism in the Iberian Peninsula and the centralist rule of Francisco Franco temporarily weakened, but failed to stop Catalan dreams of full self-government. Pro-independence sentiments systematically revived, entering the final phase in 2006 and were reflected in the drafting of a new statute of autonomy. Catalan legislators demanded a record of the primacy of the Catalan language, the possibility to create a completely sovereign judicial system, and the official recognition of the Catalans as a separate nation. Four years later, this controversial postulate was declared unconstitutional and - as such - immediately revoked. This decision of the Spanish Constitutional Court provoked multimillion people protests in Catalonia and made the idea of building their own state more vivid than ever before.

When the Junts pel Si coalition gained power after the elections in the autumn of 2015, President Artur Mas, the leader of Catalonia, began to openly direct his attention towards the independence of the region. After he had twice failed to gain enough votes in support of his investiture, at the beginning of January 2016 the parliament decided to appoint Carles Puigdemont as the new president. Following the path set by his predecessor, he immediately started building the foundations for an independent Catalan state. The milestone event - an attempt to organise an independence referendum (which ultimately took place on 1 October 2017 in an atmosphere of civil unrest), as well as a subsequent unilateral declaration of independence on 27 October 2017 - threatened the current political order not only in Spain, but also in other European countries (especially in those facing the challenges of regionalism, nationalism and separatism within their own borders).

In this context, the prospect of creating a Catalan Republic could set a dangerous precedent, possibly changing the shape of the political map of the 
whole continent. The multitude of European regions potentially interested in disconnecting from their state centres, or wishing to attain a greater degree of autonomy, has resulted in the reluctance of European leaders to take a longstanding position on the issue of Catalonia. Both the member states of the European Union and the United States of America decided to make a declaration that the conflict was an internal Spanish problem; therefore, they did not feel entitled to interfere or mediate.

\section{An independent Catalonia in the European Union - a real project or a utopia?}

The symbols of the independence movement - whether in the form of yellow ribbons, attached to the clothes of the inhabitants of Catalonia, or slogans painted on the facades of buildings calling for the restoration of the freedom for those detained after the referendum in the autumn of 2017 - have become an almost integral part of Barcelona, photographed by European tourists with no less frequency than the architectural works of Antonio Gaudi. The fact that the so-called Catalan case has aroused the growing interest of external observers became possible not only thanks to the activities of the separatists themselves, who have tried to attract the attention of the international community, but also due to the legal, ethical and moral doubts that constitute not just the background, but rather the primary strategy of Spanish-Catalan political struggles within the European Union.

The first of the most controversial legal dilemmas was the aforementioned Catalan aspiration for legal recognition as a separate nation. The Constitutional Court stated that 'the Constitution does not know any other nation than the Spanish (...) and only through it can the sovereignty of the Spanish state be realised'. ${ }^{3}$

Although the letter of the law leaves little room for alternative interpretations, it is impossible to ignore the question of whether this Spanish court order should only be associated with a true attachment to the idea of the rule of law, or should perhaps be considered an attempt to prevent the potential intensification of Catalan independence efforts. By acknowledging the existence of a separate Catalan nation, Spaniards might have opened the gate to a wider political, cultural or economic autonomy - and even full territorial demands (which turned out to be an accurate forecast). It is also worth noting that the Catalan intention in their struggle to have their separate nationality recognised was not purely for honourable and romantic reasons. It was a precisely thought-out strategy, aimed at preparing the ground for a planned struggle for sovereignty within the European Union, in the process of which the argument of the right of nations to self-determination would be raised. It was perfectly understood that in order to find support for its own independence in the European arena, it would be necessary to use tools which Spain's internal laws would find it impossible to undermine - human rights. 


\section{The European Union - Ally, Opponent or Means to an End?}

The conflict between the parties, seeking support for their own actions in the provisions of the Constitution of Spain or in the idea of human rights (which is a key foundation of the European Union), flared up in the period preceding the controversial independence referendum of October 2017. The central authorities tried to prevent the plebiscite and when they failed, ultimately decided to intervene with the security forces. According to Article 2 of the Constitution, the state is based on the "unbreakable unity of the Spanish people, the common and undivided homeland of all Spaniards'. ${ }^{4}$

This translates into the inadmissibility of secession of any of the regions and in the event of such an attempt, Article 155 of the Constitution authorises the Spanish authorities to use all means necessary to make the community enforce these obligations or protect the public interest - including the possibility of suspending the autonomy of the region concerned.

Catalan separatists, although they avowed respect and understanding for such constitutional arguments, decided in this discourse to draw on higherlevel legal acts, international treaties that confirm the need to prioritise human rights. The parliament of the region - in emergency mode and by simple majority - adopted two key laws for the process: the law on the transition system and the law on the referendum. Both were used to justify the legal validity of Catalan actions although both - as their content was in clear contradiction with the provisions of the Constitution and the procedure itself raised many doubts - were rejected by the parliamentary opposition and the central authorities. The Catalan government has argued that - as the democratically elected power - it is pursuing the will of the voters, having on its side not only a mandate obliging them to fulfil campaign promises, but also international law. As we can read in the preamble of the Catalan Act on the referendum of 6 September 2017:

the International Covenant on Civil and Political Rights and the International Covenant on Economic, Social and Cultural Rights approved by the General Assembly of the United Nations on December 19 1966, ratified and binding in the Kingdom of Spain since 1977 (...) recognize the right of nations to self-determination as a fundamental human right. Similarly, Article 1.2 of the Charter of the United Nations and the Statute of the International Court of Justice stipulates that friendly relations between nations based on respect for the principle of equality and self-determination of nations must be developed. ${ }^{5}$

Although it is impossible to undermine this argument and question the rights of nations to self-determination, serious doubts arise when we look at Catalonia as an entity wishing to exercise this same right. The Catalans, despite undeniable documentation of their own cultural and linguistic identity, 
have not been officially recognised as a separate nation by any of the EU members.

Another doubt that needs to be raised is the question of whether human rights always and unconditionally occupy a higher position in the hierarchy of legal acts and should be prioritised over the internal law of a sovereign state. According to constitutionalists, the Basic Law allows for limiting or suspending human rights, especially in situations which threaten such values as national security, public safety, public health and sometimes even public morals. It is clear that the Catalan decision to organise an independence referendum, which may entail attempts at the secession of a part of Spain and thus threatening the integrity of the state, bears all the hallmarks of the situation described above, allowing for the exclusion of certain human rights. Throughout the entire Spanish-Catalan discourse, however, no reference was made to the problem of these categories, completely ignoring the need for a debate on both legal orders, possible exclusions and justifications. As the example of Catalonia demonstrates, the lack of a public European debate devoted to the contemporary meaning of and possibilities of referring to human rights, as well as avoiding dialogue, leads to compromise barriers and deepens mutual misunderstanding, leaving the impression that the EU and its values may only be a means to and end: Catalan independence.

\section{Was using force against voters and the problem of so-called political prisoners a European problem?}

The low turnout of $43 \%$, largely as a result of the abstention of opponents to independence, as well as the confiscation of a significant number of electoral cards, made the unconstitutional referendum in Catalonia itself an unreliable barometer of real support for secession, therefore providing no mandate to declare independence. However, this event had far-reaching consequences, drawing the attention of the European community to the problem of Catalonia, and also indirectly forcing foreign institutions to take a stand on the events in this region of Spain. The use of force against voters, as a result of which almost 900 people were injured, has been widely commented on by the international press and Human Rights Watch, who called it unjust and excessive. The latter stated,

detailed investigation into three cases found that national police and Civil Guard officers used excessive force on October 1 in Catalonia. The police may well have had the law on their side to enforce a court order but it didn't give them the right to use violence against peaceful protesters. ${ }^{6}$

The declaration of independence, which was announced shortly after the plebiscite, resulted in a wave of repression against representatives of the separatist movement - and therefore yet another human rights dilemma. Nine 
ministers of the Catalan government and two pro-independence activists were arrested, which made the Catalan Prime Minister Carles Puigdemont and several of his colleagues leave the country and seek refuge in Belgium - not unreasonably, as a European Arrest Warrant was issued and serious accusations were made, threatening them with prison sentences for rebellion and embezzlement of public funds. Although the Catalans turned out to be strongly divided when it came to the idea of independence and the referendum, the majority proved anxious about the growing problem of such so-called political prisoners. The argument was raised that the Spanish amendment to the Penal Code from 2005 decriminalised participation in a referendum, even one deemed illegal, since between 2003 and 2005 it had carried a possible prison sentence.

A great surprise for the Catalan authorities - already banned under Article 155 of the Constitution - was the complete lack of support from European Union entities. It seems that the Catalans had not so much hoped for the recognition of a new republic (which - as correctly predicted - would require time and skilful diplomatic efforts), but at least criticism of the Spanish judiciary and of the detention of legally elected representatives of Catalan society. In the practice of international public life, it is still believed that the main responsibility for the implementation of human rights rests with the state. Responsibility is also borne by the international community, but it is of a secondary character and is mainly one of control. However, as has been noted by constitutionalists, since the adoption of the Vienna Declaration of 1993, one of the major barriers - an artificial division between internal and international human rights problems - has disappeared, obliging the international community to intervene when faced with a suspected violation. It seems, therefore, that the reasons for the inaction of the European community during the Catalan conflict should be sought elsewhere, namely in pragmatism.

\section{Quo vadis Europe?}

Addressing those dilemmas and discussing these problems in the European community is vital, as the scale of regionalist and separatist movements on the continent remains significant. For years their leaders have been watching the Catalan path to independence with growing interest and waiting for a sign of a changing political climate. Therefore, by giving support to or merely showing interest in the problem of Catalonia, the official authorities of such countries as Belgium, France, Italy, Greece, and Germany, or the European Union institutions, could be interpreted as giving a 'green light' to local groups demanding autonomy or independence. This perspective, albeit short-sighted, seems to have been taken seriously by policy makers, including the President of the European Commission. Jean-Claude Juncker, who stressed that 'if we allow, but it's not our business, that Catalonia becomes independent, others will do the same and I wouldn't like that. I wouldn't like a European Union in 15 years that consists of some 90 states'. $^{7}$ 
Statements in the same spirit and made by other European (and world) leaders, are often accompanied by a self-justification taking the form of the statement that Catalonia would not cope as an independent state as it does not have an economy strong enough to support the creation of new state institutions and, perhaps even more vitally, that Catalonia lacks international support. Although the absence of recognition of the Catalan state de facto negates the possibility of this entity's existence and should therefore discourage further separatist actions, the independence process itself seems to be continuing.

Having said all that, one could ask why, despite these numerous doubts, did the Catalans decide to raise the argument of human rights and concentrate their actions on the European arena. The answer is obvious: a combination of pragmatism and of having no alternative. Regardless of whether the belief in human rights is derived from John Locke's 17th century idea of the law of nature (which guarantees every individual the freedom to decide for themselves, both in personal life and in politics), or from the contemporary libertarian theory of Robert Nozick's minimal state vision, human rights are currently the main (and in the case of some conflicts - the only) weapon at the disposal of individuals, ethnic groups, nations and nationalities trying to justify their reasons and rights in the public sphere. Formal and legal dilemmas which come up as stateless nations and ethnic groups participate in international relations, especially in the context of human rights, thus seem to present a serious interpretative challenge. Yet this is not where the problem ends. The Spanish-Catalan struggles shed light on serious ethical and moral doubts and pose an important question as to whether European values grant privileges to the individual/group at the expense of the whole community, or - on the contrary - if we are faced today with the acceptance of violations of individual/group rights in order to ensure the peace and prosperity of the majority? Which concept is 'just'?

'Justice', a key word that so often appears in European discourse, especially in the context of human rights, poses many definitional problems. Both Catalans and Spaniards (as well as the international community) use it to justify their actions, interpreting it on the basis of different criteria. However, before we evaluate any of them and choose only one interpretation, it is worth asking whether today, in this era of universal acceptance of the idea of liberal culturalism and the belief that cultural and ethnic groups have their own normative systems, are we entitled to accept any definition as universally binding? Is it legitimate to persuade people to understand justice in the spirit of utilitarianism (wherein justice consists of the sum of happiness being higher than the sum of unhappiness), or according to a liberal concept (convinced that individual rights should always come first and therefore equating justice with freedom of choice) or, finally, to view justice as a virtue (positing that virtue and morality take precedence, because only something moral can be just)? Despite the numerous doubts that encourage the acceptance of relativism, practitioners involved in the interpretation of human rights are inclined 


\section{Agnieszka Grzechynka}

towards the third way of reasoning. Justice should be based on universal moral principles and universally recognised ethical principles. But how strong will they prove when confronted with the priorities of modern European states, conformism and particular political interests? The question remains open.

\section{Notes}

1 As I proposed in my book The Doctrine of Catalanism and the Contemporary Catalan Policy Towards Immigrants, (Wydawnictwo Akademii Ignatianum 2017) it is worth looking at catalanism as a trend stemming from both the main trunk of nationalist thought (in its specific, pacifist form born on the basis of Spanish social realities, separating itself from negative racist and xenophobic connotations and emphasising the superiority of one's own nation over others) as well as the branch of conservative thought (emphasising patriotism and attachment to traditional national values, growing out of the sense of the uniqueness of elements of one's own tradition and culture - especially language - which is to provide legitimacy. This is not so much to calcify existing political solutions, but to make changes in the name - and favour of - the national interest).

2 Jordi Pujol is a longtime, former leader of the now defunct political party Convergència and Unió. He emphasised the inclusiveness of Catalan nationalism, suggesting that anyone who wants to be a Catalan - is a Catalan. As I argued in my book, the pujolistic 'voluntad de ser' (will to be) had a significant influence on the later shape of Catalan immigration policy.

3 'Sentencia 31/2010, de 28 de junio de 2010', http://boe.es/boe/dias/2010/07/16/pdfs/ BOE-A-2010-11409.pdf accessed 19 April 2019.

4 'Constitución española de 1978 con enlaces', www.congreso.es/portal/page/portal/ Congreso/Congreso/Hist_Normas/Norm/const_espa_texto_ingles_0.pdf accessed 17 June 2020.

5 'LEY 19/2017, de 6 de septiembre, del referéndum de autodeterminación', http://notic ias.juridicas.com/base_datos/CCAA/604479-1-19-2017-de-6-sep-ca-cataluna-ref erendum-de-autodeterminacion.htm accessed 19 April 2019.

6 Human Rights Watch, 'Spain: Police Used Excessive Force in Catalonia', www. hrw.org/news/2017/10/12/spain-police-used-excessive-force-catalonia accessed 12 April 2020.

7 BBC News, 'EU Spain: Juncker does not want Catalonian independence', www. bbc.com/news/world-europe-41610863 accessed 23 May 2020. 


\section{9 'Poland in Europe, Europe for Poland' \\ National populist narratives on the example of Kukiz'15}

Matgorzata Maria Fijat

\section{Introduction}

The establishment of the Kukiz'15 movement in 2015 has been an event unprecedented on the Polish political scene since 1989. The demagogic activity of its members, who present simple solutions to complex problems in an emotionally charged manner, seems to indicate that the movement consciously utilises a populist strategy to build up its socio-political role and particularly that of the movement's head, the singer Paweł Kukiz, as a populist leader. This chapter attempts to analyse populist political narrative based on the example of this formation in order to review the vision of politics it presents, with a particular emphasis placed on its attitude towards Europe and European integration.

\section{The origins of the movement}

The origins of the Kukiz'15 movement can be traced back to early 2015, when the then councillor to the Lower Silesian regional parliament and rock musician Paweł Kukiz announced his intention to run in the presidential election with the aim to 'restore the subjectivity of citizens', as he stated. ${ }^{1}$ For him, running to be the head of state was a natural consequence of his previous political activity, which was aimed primarily at introducing singlemandate constituencies in the elections to the lower house of parliament, i.e. replacing the current proportional representation with a majoritarian one. The change of the electoral law as regards the elections to the lower house of Poland's parliament and the introduction of single-mandate constituencies would mean, according to Kukiz's proposal, dividing the country into 460 constituencies, which is the total number of seats in the lower house of parliament. Any number of candidates could run in each of the constituencies, but only the person with the highest number of votes would win the seat. As a supporter of this solution, Kukiz emphasised that its greatest advantage would be to 'de-politicise' the elections. The number of votes obtained would be decisive for the election of a representative instead of their position on the ballot. ${ }^{2}$ 
By posing as an 'anti-establishment' figure and with no formal support from any political party, Kukiz primarily counted on support from 'ordinary citizens'. ${ }^{3}$ With the slogan Potrafisz Polsko! ('You Can Do It, Poland!'), the singer tried to present himself as an actual and unique opponent of mainstream parties and political elites in both Poland and Europe. Stipulating changes to electoral legislation and criticising the Polish political system allowed Kukiz to come in third in the elections with approximately $21 \%$ of the vote. His main electorate consisted of people up to 24 years of age, $40 \%$ of whom voted for him. ${ }^{4}$ It was an unprecedented phenomenon in Polish political life since the fall of communism in 1989.

From the perspective of later developments, his success in the presidential election was undoubtedly a significant event. It provided sufficient grounds to create a political movement and gave a real opportunity for success in the parliamentary elections which were to take place five months later, on 25 October. At the end of July 2015, the Komitet Wyborczy Wyborców Kukiz'15 ('Kukiz'15 Voters' Electoral Committee', KWW) was established, with its name directly referencing the singer's surname. After the spectacular outcome in the presidential election, it was predicted that Kukiz's movement would win seats in the Sejm, so the result obtained in the elections to the lower house of parliament did not come as a surprise. In October 2015, KWW Kukiz'15 took third place, receiving 1,339,094 votes, which accounted for $8.81 \%$ of the vote and translated into 42 seats. $^{5}$

In terms of political communication and discourse building, the leader's declared 'anti-establishment' and 'anti-partocracy' stance formed an important element - together with obvious references to the interest of the people in contrast to that of the elite. ${ }^{6}$ Even before the official formation of the movement, on 1 June 2015, Kukiz declared the following in one of the entries on his Facebook profile:

The fact that I don't want to form a party does not mean that I don't want the supporters of change to Poland's political system to enter the Sejm. For years people have been conditioned to think that it's only political parties who may have their representation in the parliament $(\ldots)^{7}$

According to Kukiz, this way of thinking is nonsensical. The musician also emphasised that he wished to bring together the diverse voices that say "no to the current partocracy'. He stressed that he did not intend to create a 'Kukiz party' because he did not care about power, but about systemic changes, e.g. in order to be able to do what he loves in the future - make music. "In a free, common Poland', as he added. ${ }^{8}$

A review of his actions and the political postulates on which the Kukiz election campaign was based can often be regarded as a manipulative way of offering populist formulas to create a role for oneself. The political reality outlined in such a manner allows him to position himself as one of the citizens 
first, fitting into the category of 'togetherness' and the category of vox populi, a politician speaking on behalf of the people, and only then to place himself within the Kukiz'15 political group, without exposing the structure of individual roles. His efforts have enabled him to create an image of a politician who is the only one who knows 'what it's like', 'what it should be', and whose simple solutions can solve all the problems existing in politics. This approach fits perfectly into the model definition of contemporary populism presented by the Dutch political scientist Cas Mudde, stating that it is an ideology characterised by the presence of a charismatic leader and based on the principle of dividing society into two homogeneous and antagonistic groups: 'the pure people' and 'the corrupt elite'.

\section{An outline of Kukiz'15 political ideas}

The vision of the Kukiz movement's new policy was set out in a document entitled Strategia Zmiany ('The Strategy for Change') which was adopted during the 2015 parliamentary campaign. The document, drawn up by a team of experts from the newly formed grouping, is divided into three chapters and presents postulates concerning the issues of 'democracy', 'wealth', and 'security'. ${ }^{10}$ Although its authors clearly emphasised that it was not a political programme, it is difficult not to notice the analogies with a typical party programme. The Strategy for Change, with its telling subtitle 'You Can Do It, Poland' and the chief slogan of 'Let's bring Poland back to Citizens', starts with the following passage:

We love Poland. We are members of a great and wonderful Nation. We are the voice of the Nation that has awakened and wants to regain control of its country. We know that everything that is best in our country comes from Poles' patriotism, diligence, and innovation. ${ }^{11}$

The analysis of the political message created by Kukiz'15 reveals a clear, negative image of a state divided along the line of 'us-them', which is constantly present in the grouping's narrative, and reflects the society-authority dichotomy. Kukiz uses persuasive forms not only to create a dualistic division of the world according to the 'us-them' scale, but also utilises inclusive forms to build his own ambiguous image as a relay of citizens' thoughts. ${ }^{12}$ Speaking out against partocracy and simultaneously defending the people was a constant element in the communications of the group's leader. The antagonistic division between the people and the elite, a flagship trait of populism, is clearly visible in the discourse he was creating. By using the slogans characteristic of this phenomenon, the politician aims to reach all those who have been in any way victimised by institutions and authorities, i.e. to reach potential voters. Opposition to the cartelisation of the party system was expressed by the leader of Kukiz'15 both in official election materials and during concerts 
organised as part of the campaign. The narrative built using campaign ads also included elements aimed at mobilising the movement's supporters in the form of requests directed at voters:

Poland is waking up to our dreams. I ask of you to go to the polls on 25 October and give your vote to the people who do not only make promises but sincerely want to change our country, change its constitution, bring it back to citizens, make it civic (...). ${ }^{13}$

Systemic issues constitute the starting point for the postulates of the Kukiz'15 movement. Therefore, it is not surprising that they were presented first in the Strategy. While expressing its dissatisfaction with the current political system, Kukiz'15 assigns a principal role in shaping it to the citizens. This would be achieved primarily through the aforementioned change to the electoral law (single-mandate constituencies), shifting from proportional representation to a majoritarian one, but also through the enactment of a new constitution, as well as the introduction of the mechanism of an obligatory, nationwide, nonthreshold referendum, and the establishment of the so-called 'referendum day', on which all issues signed by at least half a million citizens would be voted. By advocating for the presidential system, Kukiz'15 activists propose that the executive power should belong exclusively to the president - elected through general elections, but lacking the right of initiative, since it would belong only to deputies and citizens. As far as changes to the state's political and government system are concerned, the movement also proposes to subject courts to the control of the citizens, make public expenditure completely transparent, and to abandon the system of financing political parties from the state budget. Moving a large number of offices and institutions out of Warsaw, aimed at stimulating civic activity in those regions, can be considered an innovative idea. ${ }^{14}$

The postulate of a constitutional provision requiring the adoption of balanced budgets both at central and local government levels constitutes yet another issue involving the political system. By opting for the British tax system, the formation aims to implement tax reforms in Poland which would include, among others: the liquidation of personal income tax or the introduction of a zero VAT rate for essential products such as medicines, food, city and rail transportation, and access to the press. ${ }^{15}$ In addition to these proposals in the area of social and economic issues, the group is also in favour of taxing foreign corporations, simplifying laws, and reducing the bureaucratic apparatus. It announces it will fight against corruption and nepotism in state and local administration. ${ }^{16}$ The third 'pillar' of Kukiz'15's strategy involves issues related to internal and external security.

In its early days, the movement described itself as devoid of any ideology. However, its main postulates and the characteristics of the community gathered around it - descending from radical right-wing circles - provide the basis for determining its political orientation. In addition to non-partisans, the Kukiz'15 electoral committee lists in 2015 included representatives of 
right-wing conservative and Eurosceptic parties, such as the Real Politics Union (Unia Polityki Realnej, UPR), the Congress of the New Right (Kongres Nowej Prawicy, KNP), the Right Wing of the Republic (Prawica Rzeczypospolitej, PR), and a few members of Poland Together (Polska Razem, PR), United Poland (Solidarna Polska, SP), the Labour Party (Stronnictwo Pracy, SP), and SelfDefence of the Republic of Poland (Samoobrona Rzeczypospolitej Polskiej, SRP), as well as, interestingly, representatives of the National Movement (Ruch Narodowy, RN), a Polish political grouping of nationalist, conservative, national-catholic and Eurosceptic nature associated with extreme nationalist organisations, i.e. the All-Polish Youth (Młodzież Wszechpolska, MW) and the National Radical Camp (Obóz Narodowo-Radykalny, ONR). The aforementioned political formations are the organisers of the annual Independence March, an event that takes place in Warsaw on each 11 November, the anniversary of Poland regaining its independence. According to the organisers' declaration, the march is 'an element of celebrating the National Independence Day and a demonstration of attachment to Polish tradition and patriotism', but has been recognised by the British daily The Independent as promoting xenophobic and white supremacist ideas. ${ }^{17}$ It is worth noting, however, that following nationalists' anti-Semitic demonstrations in front of the Presidential Palace in Warsaw in February 2018, the leader of Kukiz'15 apologised in one of his Facebook posts for introducing them to the Sejm and distanced himself from these groups. ${ }^{18}$

When analysing the Kukiz'15 programme, one may conclude that it is a right-wing movement, which is mainly influenced by recurring nationalistic and conservative ideas, such as a strong state or the primacy of national interests, as well as disapproval of deep European Union (EU) integration. On the other hand, it should be noted that the movement is not devoid of liberal ideas manifested in postulates like low taxes or solutions for business owners. This allows the group to be placed in the socially conservative and economically liberal category, which is consistent with the current self-identification of the movement. ${ }^{19}$ Using contemporary typologies of populism, ${ }^{20}$ the group can be considered a model example of right-wing populism, appearing in the form of the so-called 'New Populism' derived from the New Politics ${ }^{21}$ or the populism of the radical right. ${ }^{22}$ As far as the traits of a populist leader are concerned, however, it should be noted that, by discussing various aspects of the functioning of politics, Paweł Kukiz leaves no doubts as to the image he is shaping, which fits into the framework of populism mainly due to the language forms he is consciously using. As the leader of a movement explicitly connected with populist communication, he is consciously creating his image as a populist leader of the people, a leader who aims to be a vox populi of sorts.

\section{Kukiz'15's European programme}

The attitude of the Kukiz'15 movement towards foreign and European policy issues can be categorised as Eurorealism or soft Euroscepticism. ${ }^{23}$ It should be 
emphasised that while basing its postulates on the priority of national interests and opposition to the expansion of EU law, the introduction of Poland into the Eurozone, or the renegotiation of the energy and climate change package, the grouping does not reject the idea of European integration. As envisioned by the EU Founding Fathers who established an international organisation to guard the peace and sustainable development of its member states. Kukiz'15 is not fundamentally averse to the very idea of European integration or Poland's membership in the EU, but rather expresses reservations about certain aspects of integration, which in effect leads to partial opposition to the Community. ${ }^{24}$ It supports further development of economic cooperation and the equalisation of economic development in member states, while standing against limiting their sovereignty, whether by interfering in the internal affairs of member states or imposing a common policy towards third countries as well as legal solutions that contradict the socio-cultural conditions of individual countries.

In the light of this trend, it is worth noting that in 2019 the Swedish think tank Timbro carried out an analysis of support for populist parties which are characterised by, among other things, the creation of conflicts between 'people' and 'elites', strong nationalism, striving to remove institutional restrictions on authority, or anti-capitalism. According to the Civil Development Forum (Forum Obywatelskiego Rozwoju, FOR) regarding the aforementioned Populism Index, the sum of the election results of the right-wing Law and Justice (PiS) and Kukiz'15 placed Poland fourth in the European ranking in terms of support for populists, right behind Hungary, Greece, and Italy where support for populist groups exceeded $50 \%,{ }^{25}$ based on the results of the last elections. Therefore, it is not surprising that an alliance was formed in the run-up to the European Parliamentary elections in May 2019 between the leader of Kukiz'15, already described by the Italian press as the 'Polish Beppe Grillo'26 in the context of the 2015 presidential elections, and 'pro-citizen' populist political groups from Italy (Five Star Movement, M5S), Greece (AKKEL), as well as Finland (Movement Now, Liike Nyt), and Croatia (Human Shield, Živi zid). In the context of the alliance, the daily Corriere della Sera featured an article that decried and mocked the leader of the M5S, Luigi Di Maio, who - in turn - attributed sympathy to far-right movements and parties to Matteo Salvini's League while simultaneously going to Poland in search of allies before the European elections and visiting 'a congress of the extreme right-wing party Kukiz'15, which itself is taking an anti-abortion stance and is accused of neo-Nazi sentiments' ${ }^{27}$

The programme of these groups, with their vision of a united Europe, contained in a ten-point document entitled The European Manifesto, was adopted at a conference attended by the leaders of these groups (Paweł Kukiz, Luigi Di Maio, Evangelos Tsiobanidis, Karoliina Kahonen, Ivan Vilibor Sinčić) in Rome in February 2019 who came together again two months later at a meeting in Warsaw. ${ }^{28}$ The document, which constitutes an international 
agreement for changes at the European level, mimics the vision of politics presented by the Kukiz'15 movement at the national level. ${ }^{29}$

The issues of the political system based on direct democracy and the resulting influence of citizens on the decisions, as postulated by Kukiz'15 on the Polish political scene, are similarly a key topic for people gathered around the above-mentioned groups. Hence, the slogan 'A Europe closer to its Citizens' was the first statement of the Manifesto. Kukiz'15, expressing dissatisfaction with the current political system, calls for an expansion of direct democracy and so-called e-democracy. It proposed to introduce voting via the Internet (e-voting), both in national and European elections. The main beneficiaries are citizens for whom this procedure is intended as a convenience. The text of the commentary explains this message without leaving any doubts. Due to the colourful rhetoric present throughout the document, it is worth quoting it directly:

Politicians and bureaucrats who have overrun EU institutions are completely detached from the lives and needs of ordinary citizens. They are a modern, Brussels aristocracy. This needs to change. That is why the tools of direct democracy and e-democracy should be strengthened, so that citizens can directly influence EU institutions. ${ }^{30}$

This quote should be considered tendentious, since it takes up one of the most important populist postulates, i.e. placing the ideas and will of the people at the centre, as well as a critique of the extensive system of EU bureaucracy. It fulfils its goals as a piece of propaganda and shapes new social attitudes. Due to the cooperation with the M5S, the leader of Kukiz'15 was very positive about the Italian policy, recognised as the European leader in introducing the tools of direct democracy in the country. He postulated following the Italian model and reforming how referendums are organised. In addition, the document's authors criticised the procedure of the European Citizens' Initiative, considering it unreliable due to the requirement to gather too many citizens' declarations (at least one million). Kukiz'15's antipathy towards Brussels is also reflected in its critical attitude towards the so-called trialogue, that is, meetings between representatives of the European Commission, the European Parliament, and the Council of the European Union and, in a broader spectrum, against the secrecy of their sessions and documents drawn up therein.

Supporting the rejection of anachronistic ideologies and artificial divisions into 'right-wing' and 'left-wing' parties, the activists of 'pro-civic' parties postulated that issues decided both at the EU level and in individual countries should be divided into those 'good' and 'bad' for citizens. It was assumed that problems affecting citizens of individual countries, such as combating corruption or defending citizens' rights against multinational corporations, are issues that connect Europeans regardless of their views on world issues. 
By referring to the common good, the need for a new vision of Europe and 'immediate and profound reform of the EU' was underlined.

The postulate of 'a new future for the "Europe" project', assuming international cooperation while maintaining respect for national identity, corresponded with ideological issues. As Kukiz declared, 'European integration is a guarantee of peace and sustainable economic development in all countries belonging to the Community, but it must involve equality among all countries'. ${ }^{31}$ In his opinion, excessive interference in the 'common' policy by more developed member states, such as Germany and France, may bring about the collapse of European unity. This hypothesis is based on the example of Brexit, where the Brits' discontent was confirmed by their protest expressing itself in the most radical form possible, i.e. the UK leaving the EU. According to Kukiz, by not wanting to adapt European policy to the dynamically changing realities and demands of individual nations, EU decision makers have not learned their lesson from the current situation. In line with the movement's assumptions, the foundation of project 'Europe' should be found in partnership and equal treatment of all nations with respect for their identity and needs. In keeping with the programme under consideration, only a dialogue between member states that leads to concrete, positive actions could change the increasingly visible negative attitude of many Europeans towards EU structures.

Another one of the chief theses presented in the document was the 'Honest Europe' slogan, which was to be implemented by fighting against corruption and organised crime - deemed one of the greatest threats to how EU countries are functioning. As Kukiz'15 representatives emphasised, this problem 'not only destroys trust in democracy, but also causes an outflow of funds from the legal economy'. ${ }^{32}$ The document states that combating corruption in Europe should become a priority for all its member states. As Kukiz declared: 'We must find a way to stop lawlessness in the European Union so that all citizens can feel safe'. ${ }^{33}$

Going further, the authors of the Manifesto took up the issue of reforming EU institutions, with particular emphasis on reinforcing the competences of the European Parliament (EP). In the opinion of the document's authors, the EU is governed by 'undemocratic, commanding, and authoritarian institutions'. These arguments were justified in a rather surprising way. Namely, by referring to the functioning of the European Commission, which by definition - is a politically independent executive body of the EU, while in fact it is 'a gathering of Brussels bureaucrats' elected by other officials. The programme also called for increasing the role of the EP, recognised as the only impartial representative of Europeans in European politics since it is elected directly by citizens. An innovative solution would be for the EP to have a full right of initiative. It was pointed out that strengthening the competences of the EP is necessary, because the laws it passes directly affect the lives of Europeans. 'The EP must have a voice, since it is the voice of all Europeans $^{34}$ - the authors of the Manifesto proclaimed. 
In addition to these socio-economic proposals, the movement is in favour of improving the quality of life of Europeans in terms of protecting public health and the environment, reducing the impact of financial markets and multinationals, protecting products made in the EU, developing local and European agriculture, as well as implementing new programmes and tools for young Europeans. Another important issue was the call to amend migration and security policy through the introduction of a new European model for controlling migratory movements by strengthening borders with third countries and granting additional competences and powers to the European Border and Coast Guard Agency (FRONTEX). According to Kukiz'15, migration to the EU from third countries should be better controlled and coordinated, and the procedure for granting protection to refugees should also be changed. During the EP electoral campaign, the leader of the movement postulated the need to differentiate between political refugees, i.e. people actually at risk in their countries, and the so-called economic refugees, who should be properly verified and, if necessary, deported. He categorically opposed the forced relocation of refugees, which - in his view - not only poses a threat to Europeans due to insufficient verification of arrivals from outside the Union, but also violates their human rights. Kukiz'15 is of the opinion that the best way to contain the influx of refugees is to help their own homelands by supporting sustainable economic development. ${ }^{35}$

All of the proposals included in the document, justified with a short, concise, and arbitrary comment, demonstrated the politicians' intention to convince voters that it is 'ordinary' citizens who can decide the future of the European continent. Explanatory notes included in the documents provide assurance that the coalition is the only rational choice. The movement was intended to symbolise "the third way, an alternative in the dispute between Eurosceptics and Euro-enthusiasts uncritical about the domination of Germany and France'. ${ }^{36}$ The ultimate goal of the project was to create a 'civic' Europe of Homelands, capable of implementing a programme aimed at advancing economic development while maintaining political separateness and respecting the sovereignty of individual member states. It assumed simultaneous criticism of European federalism which - according to the Kukiz'15 movement - would lead to the hegemony of the EU's strongest economies over weaker countries. ${ }^{37}$

When assessing the merits of the Manifesto, it is difficult to decide the extent to which it was the personal vision of the Kukiz'15 leader or rather a representation of the views of other coalition politicians. However, it can be said that the ideological and political message of this document is clear. The Kukiz'15 movement aims to radically change current EU policy. It is worth noting that the implementation of this programme was to some degree dependent on the outcome of the EP elections which, however, did not bring the expected results. Receiving only $3.69 \%$ of the vote and failing to win any seats, Kukiz'15's defeat in the elections to the EP on 26 May 2019, as well as 
the gradual withdrawal of its members from the grouping, made the partially developed project of changing Europe obsolete. ${ }^{38}$

\section{Concluding observations}

A review of the activity of Kukiz'15, its verbalisation of national and conservative ideas and disapproval of deeper European integration, allows us to identify it as the case of a populist right-wing and Euro-realist protest movement on political and socio-cultural issues, albeit liberal in terms of economic policy. Its strategy for policy change should, however, be placed between the ideal types of 'establishment' and 'anti-establishment'. ${ }^{39}$ The grouping, characterised primarily by its strong opposition to the cartelisation of the party system by 'old parties', expresses a clear anti-party position and the need for greater control of state authorities by citizens. The offensive attitude and emotional rhetoric of the grouping, saturated with messaging clearly indicating its populist character, are also worth emphasising. A number of fundamental features of right-wing populism can be pointed out in the narrative created by the movement, i.e. treating the people as a centrepiece in its vision of the world and always showing it in opposition to the elite, the presence of a leader acting on the will of the people, as well as a simplified linguistic image of the world involving statements based on common language, close to 'ordinary people'. Kukiz uses populist exponents in order to create a typical populist and hierarchical relationship between the leader, the people, and political opponents.

The singer's spectacular political debut in 2015 , constantly citing some unspecified 'will of the people', served as a binding agent for many protest movements in the context of a strong social protest. According to the Italian historian Loris Zanatta, the cognitive horizon of populism depends on the situation of individual countries and the issues they are currently dealing with. It is therefore a matter of principle, or rather what populists consider to be principles. ${ }^{40}$ However, it is worth considering if their diagnoses are correct, whether their promises are followed by actions, and what effects do they generate. As the Polish political scientist Ewa Marciniak rightly pointed out, Kukiz has been deemed a populist mainly because of his vision of shifting the electoral law in Poland towards majoritarian representation, which - in his mind - was supposed to satisfy all those who do not participate in elections because they have no one to vote for. This mechanism, as the Polish political scientist said, fits perfectly into the populist 'procedure of making people happy'. The problem is that there is no certainty that voting actually constitutes a basic need of the society. ${ }^{41}$

The postulates of the Kukiz'15 European programme raised in this chapter fit in with the vision of the Europe of Homelands, understood as a Europe consisting of Community members treated equally while respecting the sovereignty of states and the development of intergovernmental cooperation and not a supranational one in the form of federations. The distinguishing 
feature of this concept is an emphasis on the central position of citizens in place of EU institutions. The characteristic trait of this concept lies in the emphasis it places on the socio-cultural and economic conditions and identities of individual EU member states. There is no doubt that the grouping is not an opponent of the EU, but rather a supporter of its fundamental reform. At the same time, it should be noted that, in its programme, the movement does not promote the idea of the so-called 'Polexit', i.e. Poland's potential withdrawal from the EU.

Dubious decisions made by the Kukiz'15 leader over the course of his political career, such as forming an alliance with the Polish People's Party (PSL) $^{42}$ before the 2019 parliamentary elections in Poland, led to a gradual absorption of the movement's members by other political formations. ${ }^{43}$ Although it is unlikely that the movement is ever going to return to its heyday, it is expected that it will seek to maintain its current position and cooperate within the coalitions that are being formed (both nationally and internationally), following the principle of 'a drowning man will clutch at any straw'. At the same time, it will try to maintain, at least fragmentarily, its existing political postulates. Although Kukiz's strategy seems inconsistent, ambiguous and vague, it is worth noting that the Kukiz'15 grouping does not deny the foundations of democratic principles. It only leads to a reduction in decision-making efficiency, and also gives the impression of a certain inconsistency.

The 2019 EP elections can be considered a turning point in the political existence of Kukiz'15. Comparing the activity of its members before and after the elections, we can see a significant decrease in their involvement in the movement. The most serious risk for the grouping now appears to lie in the possibility of its leader wrongly assessing the credibility of allies' guarantees (both domestic and foreign). However, one may conclude that the presented vision has a cognitive value, as it clearly reveals the intentions of anti-establishment populists, which do not seem to change with time. The elements visible in Kukiz'15's discourse that directly point to the populist nature of the grouping may provide a basis for comparison with other political entities operating not only in Poland but also in other parts of Europe and the world.

\section{Notes}

1 Paweł Majewski and Jacek Nizinkiewicz, 'Paweł Kukiz: Jestem od idei. Zmienię system', (2015), Rzeczpospolita, www.rp.pl/pawelkukiz accessed 26 June 2020.

2 This system is used, among others, in the UK and the USA, but also in France and India. See Dariusz Grzędziński, 'O co chodzi w JOW-ach? Co by było gdyby w Polsce obowiązywały jednomandatowe okręgi wyborcze?', (2015), Polska Times, https://polskatimes.pl/o-co-chodzi-w-jowach-co-by-bylo-gdyby-w-polsce-obowi azywaly-jednomandatowe-okregi-wyborcze/ar/3858819 accessed 26 June 2020.

3 Paweł Kukiz, 'Lider i założyciel Kukiz'15', http://kukiz15.org/zespol/pawel-kukiz accessed 26 June 2020. 


\section{Matgorzata Maria Fijat}

4 Państwowa Komisja Wyborcza, 'Wybory Prezydenta Rzeczypospolitej Polskiej', (2015), https://prezydent2015.pkw.gov.p1/319_Pierwsze_glosowanie.html accessed 9 June 2020. See also: Antoni Dudek, Historia polityczna Polski 1989-2015, (Wydawnictwo Znak Horyzont 2016), 675.

5 Państwowa Komisja Wyborcza, 'Wybory do Sejmu i Senatu Rzeczypospolitej Polskiej', (2015), https://parlament2015.pkw.gov.pl/349_Wyniki_Sejm.html accessed 9 June 2020.

6 Arkadiusz Lewandowski, 'Antysystemowość ruchu Kukiz 15 w okresie kampanii wyborczej 2015 roku', in Katarzyna Walecka, Kinga Wojtas (eds), Nowe partie i ruchy polityczne. Praktyka i idee wspólczesnych demokracji, (Cardinal Stefan Wyszyński University Press 2017).

7 Paweł Kukiz, 'Nie chce tworzyć żadnej partii', www.facebook.com/kukizpawel/ posts/901098533291201 accessed 9 June 2020. Original spelling, no changes.

8 Ibid.

9 Cas Mudde, Populist radical right parties in Europe, (Cambridge University Press 2007).

10 'Strategia Zmiany. Kukiz'15', http://kukiz15.org/images/PROGRAM/StrategiaZmiany-KUKIZ15-dla-Polski.pdf accessed 12 April 2020.

11 Ibid., 3.

12 Małgorzata Kołodziejczak, Marta Wrześniewska-Pietrzak, 'Przywódca populistyczny i jego językowy obraz w aspekcie retoryki dominacji na podstawie wypowiedzi Pawła Kukiza. Perspektywa politologiczna i lingwistyczna', (2017), 24, Poznańskie Studia Polonistyczne Seria Językoznawcza, 1, 27.

13 Paweł Kukiz, 'Polska budzi się z naszymi marzeniami', http://pressmania.pl/spotwyborczy-kww-kukiz15-pawel-kukiz-polska-budzi-sie-z-naszymi-marzeniami/ accessed 14 June 2020.

14 'Strategia Zmiany', (n 9), 7-14.

15 Encyklopedia Kukiz'15, Niskie podatki, http://kukiz15.org/program/krajowy/nis kie-podatki accessed 26 July 2020.

16 'Strategia Zmiany', (n 9), 16-23.

17 Vanessa Gera, 'Fascists to stage' biggest' far-right march in Warsaw on Polish Independence Day', The Independent, (London, 10 November 2017), www.independent.co.uk/news/world/europe/warsaw-fascist-far-right-nazi-march-warsawpoland-independence-day-a8048561.html accessed 26 June 2020.

18 www.facebook.com/kukizpawel/posts/1725733717494341/ accessed 26 June 2020.

19 'Kukiz'15', http://kukiz15.org/kukiz15/o-kukiz15 accessed 26 June 2020.

20 Mudde, (n 9); Paul Taggart, 'Populizm, lud i rdzenna kraina', in Olga Wysocka (ed), Populizm, (Warsaw University Press 2010), 77-98. See also: Hans-Georg Betz, Radical Right-Wing Populism in Western Europe, (Palgrave Macmillan 1994).

21 Paul Taggart, (n 20), 80.

22 Mudde, (n 9), 32.

23 Paul Taggart and Aleks Szczerbiak, 'Theorising Party-based Euroscepticism: Problems of Definition, Measurement and Causality', (2003), 69, Sussex European Institute Working Paper.

24 Ibid.

25 Komunikat FOR 4/2019, 'Indeks Populizmu 2019: Najwyższe poparcie dla partii populistycznych od 1980 r.', https://for.org.pl/pl/a/6602,komunikat-4/2019-ind eks-populizmu-2019-najwyzsze-poparcie-dla-partii-populistycznych-od-1980-r accessed 16 June 2020. 
26 Francesco Battistini, 'Polonia, stravince la destra anti-Ue', Corriere della Sera, (Milano, 15 October 2015), www.corriere.it/esteri/15_ottobre_25/elezionipolonia-primi-exit-poll-avanti-destra-anti-unione-europea-cccbd0a4-7b53-11e5901f-d0ce9a6b55d1.shtml accessed 26 June 2020.

27 Franco Stefanoni, 'Di Maio: «Noi i moderati». La svolta dopo i gilet gialli, le accuse a Mattarella e il patto con Kukiz'15', Corriere della Sera, (Milano, 19 May 2019), www.corriere.it/politica/19_maggio_23/di-maio-noi-moderati-svolta-giletgialli-accuse-mattarella-patto-kukiz-15-7df3c00e-7d4d-11e9-bf38-280379b6a560. shtml accessed 26 June 2020.

28 'Manifest Europejski', www.sachajko.pl/pliki/Manifest-Europejski-Kukiz.pdf 2019 accessed 12 April 2020.

29 'Program Europejski Kukiz'15', http://kukiz15.org/program/europejski accessed 14 April 2020.

30 'Europa bliższa Obywatelom', http://kukiz15.org/program/europejski/europa-bliz sza-obywatelom accessed 14 April 2020.

31 'Item IV of Kukiz'15's European Programme', http://kukiz15.org/program/europej ski/nowa-przyszlosc-projektu-europa accessed 14 April 2020.

32 Ibid.

33 Ibid.

34 Ibid.

35 'EuroPAP News, Program Komitetu Wyborczego Wyborców Kukiz'15', https:// europarlament.pap.pl/okreg-nr-10/6-komitet-wyborczy-wyborcow-kukiz15 accessed 26 June 2020.

36 European Manifesto, in Polish, http://kukiz15.org/program/europejski accessed 12 April 2020.

37 EuroPAP News, Program Komitetu Wyborczego Wyborców Kukiz'15, https:// europarlament.pap.pl/okreg-nr-10/6-komitet-wyborczy-wyborcow-kukiz15 accessed 26 June 2020.

38 European Parliament, 2019 European election results, https://europarl.eur opa.eu/election-results-2019/en/national-results/poland/2019-2024/ accessed 14 April 2020.

39 Giovanni Sartori, Party and Parties System. A Framework for Analysis, (Essex 2005), 117-118; Bartłomiej Michalak, Partie protestu $w$ Europie Zachodniej. Analiza relewancji politycznej, (Wydawnictwo Adam Marszałek 2008), 24.

40 Loris Zanetta, 'Populismo, un término que pierde su sentido', www.clarin.com/ opinion/populismo-termino-pierde-sentido_0_p5CRntEhr.html accessed 15 June 2020.

41 Ewa Marciniak, 'Populizm w kampanii wyborczej', https://wiadomosci.onet.pl/ tylko-w-onecie/populizm-w-kampanii-wyborczej-prof-mar accessed 15 June 2020.

42 The Polish People's Party (Polskie Stronnictwo Ludowe, PSL) is a Polish political party founded in 1990. It mainly gathers people with agrarian, centrist and Christian Democrat views.

43 Wybory Parlamentarne 2019. Oficjalnie: PSL i Kukiz'15 wystartują wspólnie, www.rp.pl/Wybory-parlamentarne-2019/190809452-Oficjalnie-PSL-i-Kukiz15wystartuja-wspolnie.html accessed 26 June 2020. 


\title{
10 Considerations on the role of Hungary and the Hungarian nation in the European Union after 1989
}

\author{
Tadeusz Kopyś
}

\section{Introduction}

Ever since the Hungarian tribes conquered the Carpathian basin 1,100 years ago, the history of Hungary has been that of a small, destroyed nation, one which has continuously struggled to survive. It was conquered by the Tatars, the Ottoman Turks, the Nazis and the Russians. The failed uprisings of 1703 and 1848 against the Hapsburgs and the disaster of the anti-Soviet revolution of 1956 have become deeply rooted in the national psyche. The Treaty of Trianon in 1920 had a similarly serious influence on the formation of the concept of the Hungarian nation in the 20th and 21st centuries. It was so important in shaping Hungarian national identity that, even during the communist dictatorship, the great Hungarian writer Gyula Illyés claimed that anyone who feels the pain of Trianon is a Hungarian. A hundred years later, the wounds of Trianon remain open and unhealed. Many Hungarians consider it an almost personal trauma: unfair, cruel and a source of disputes over the rights of ethnic Hungarians in Romania and Ukraine, which continues to this day. Scholars have almost unanimously placed the origins of modern Hungarian nationalism to the end of the 18th century, alongside the literary works of György Bessenyei and Ferenc Kazinczy, and the resistance of the Hungarian nobility against the decision of Emperor Joseph II to introduce German as an official language throughout traditionally Hungarian-speaking territories. The further development of Hungarian nationalism can be seen as a split process, i.e. as a mass phenomenon (a bottom-up process) and an official nationalism (with a top-down course of action created by the elite). From the 18th century to the end of the interwar period, the concept of the nation was shaped mainly by the aristocracy, a cosmopolitan societal layer which identified poorly with the attributes of the nation's grassroots and focused instead on the idea of progress, European ideas and identifying the nation with the cultural and social trends which prevailed in Europe at the time. Popular nationalism, which is often associated with the figure of Lajos Kossuth, flourished for a brief period during the revolution of 1848. A number of reforms were introduced in 1848 and, with the abolition of serfdom and the restriction of the rights of the nobility, the idea of a common imagined 
community was created for the first time. However, it was expected that every member of this community would be able to speak Hungarian, something which was impossible in an era which also saw the development of Slavic nationalisms. The official Hungarian nationalism in the 19th century can therefore be described as an attempt to enlarge the imagined Hungarian community and to adjust the boundaries of this community to the state borders of the time. ${ }^{1}$

The trauma caused by the disintegration of the integrity of the Hungarian state can be seen as an injustice that disturbed the existing and enduring territorial order, but one can also speak of the conscious or unconscious 'inheritance' of trauma through the generations, something which is related to the idea of social or collective memory. Through the diffusion and subsequent remembrance of a traumatic event, it becomes part of collective memory, which means that a collective trauma can be defined as 'a traumatic event stored in the collective memory'. ${ }^{2}$ The trauma caused by the Treaty of Trianon may be considered the glue which binds the whole nation even closer together. In this sense, one could describe collective trauma as a traumatised image of the self and thus the imagined community. In this sense, it is also interesting to see trauma as an event that, through its force, attacks and even destroys the image of the self, shaking the foundations of the connections between the remembered past, the present and the expected future. ${ }^{3}$

Hungarians also like to describe themselves as ethnically distinct, as an island in a Slavic sea. They perceive themselves to be a separate race: their language is not related to the Indo-European languages that surround them and acts as a powerful glue of national identity. As early as the second half of the 18th century, there has been an ever-present fear of Hungarians assimilating with the other peoples of the region (the Slavs, Romanians and Danube Swabs). This fear contributed to the disastrous policy of assimilating other nations living in the territory of the Lands of the Crown of Saint Stephen in the second half of the 19th century. This was so disastrous because it led to conflict with the Slavic nations living in Hungary and the disintegration of the territory of the historic state in 1920.

The aim of this chapter is to analyse the manner in which nationalism and Hungarian national thought developed after 1989. To do so, however, it is necessary to delve deeper into the history of Hungary and outline the social and political conditions of the development of nationalism in this country. Amongst the Hungarian intelligentsia, there is a growing interest in their national past and the sources of their identity. The popular thesis is that Hungarians are related to oriental peoples and its popularity has grown steadily, having been in use in Hungarian academia for over a century.

\section{The concept of the nation after 1920}

The interwar period and the rest of the 20th century in Hungary constituted a turning point in terms of social, cultural and political change. The division of 
the Hungarian state after the Treaty of Trianon, in which both the territorial character of the country and the psychological state of its citizens changed radically, required a redefinition of Hungarian national identity. For small groups of young intellectuals, both inside and outside Hungary's new borders, it was a period which saw the intense questioning of traditional values and national structures. A new generation of university youth, whose future prospects had been drastically diminished by Hungary's own diminished size and status, were particularly affected by the tensions and conflicts in their socially stratified society; a society which tried desperately to adapt to its radically changed circumstances. Questions about the fate of Hungary, the 'magyar sorskérdés', and the attempts to define the role of the diaspora in the overall understanding of the Hungarian nation, led to the formation of two competing camps: that of folk writers and that of an urban elite or urbánusok. The former referred to the common people of the provinces as a reflection of what was truly Hungarian. The urban camp, based in large cities, referred to European ideas as the basis for Hungarian national identity. According to this camp, modernisation was to be based on the Western European urban model, with an ideology which was not strongly rooted in national identity. As a result, according to their critics, they are not Hungarian enough in either their feelings or understanding of culture. This image of the nation which referred to European values was strongly left wing and liberal, with its authors mainly being intellectuals of Jewish origin. ${ }^{4}$

After 1920, one third of Hungarians found themselves living outside the borders of the new state, constituting an ethnic minority in its neighbouring countries. The population of the country fell from 18.26 million to 7.61 .5 The treaty undoubtedly made the country more ethnically homogeneous. Nationalism in the post-Trianon period developed on two levels. On the one hand, efforts were made to make up for its territorial and demographic losses, leading to support in revisionism, which in turn led to the alienation of the state in the international arena. On the other hand, the elite of the time sought to improve the nation in the civilisational sense. As one politician said, 'we are a small nation, destined to accomplish great things in the spiritual field'. With Count Kuno Klebelsberg as Minister of Education, a cultural policy was launched which contained an extensive public education programme to revive Hungarian national self-awareness after the losses in Trianon. ${ }^{6}$

\section{The political transformation after 1989}

The divisions in the Hungarian elite that have been discernible since 1989 are an inheritance of the interwar period. Already in the 1970s and 80s, two main political camps had resurfaced, ones which also carried with them competing visions of the future of the nation and its place in the surrounding geopolitical reality. In 1987-1988, these camps formed their own political parties: the folk-national camp established the Hungarian Democratic Forum, while the urbánusok formed the Alliance of Free Democrats (SZDSZ) which 
was operational from 1988 to 2013. The Hungarian Democratic Forum and the Union of Free Democrats came to power after 1989, taking turns at the helm of government and with differing perceptions of national and international politics. The Hungarian Democratic Forum (MDF) aimed at the unification of the Hungarian nation, both in the country and abroad. The Forum was founded by intellectuals with a nationalist bent, including Sándor Csoóri, Zoltán Bíró, István Csurka and Sándor Lezsák. They referred to the ideological tradition of the népi-nemzeti ('populist' or 'rural-national') movement, which had been opposed to the urbánus ('urban') school of thought since the 1920s. The Forum focused on national and cultural traditions, aiming at fostering radically democratic, bottom-up politics and a 'third way' between capitalism and communism. A representative of this party, Prime Minister József Antall, the ruling centre-right government in 1990-1994, described himself as the prime minister of 15 million Hungarians in Central Europe (meaning the Hungarian diaspora in neighbouring countries, as well as those within the country).

In Hungary, the belief prevails that whoever sets the tone of the "national discourse' has the right to control the state - including the constitution and lawmaking. In the first free elections, the parties which alluded to the nation the most emerged victorious. The 1990 elections were won by the MDF, the main party of the national opposition to communism. SZDSZ, meanwhile, was composed mainly of dissidents from the former democratic opposition and reformed socialists who had held power before 1989. The first democratically elected government after 1989 began with a strong nationalist tone, with Prime Minister József Antall stating that he represented 15 million Hungarians, while the population of the Hungarian state was only 10 million. Interestingly, Antall referred to the Hungarian diaspora in neighbouring countries, but did not challenge the status quo or initiate a claims policy to reunite Hungary's pre-war areas. ${ }^{7}$ When, in the early 1990s, the leader of the far-right Hungarian Justice and Life Party, István Csurka, attacked the government's conservative policy and commitment to the rule of law, Antall replied: 'Membership of the Hungarian Democratic Forum is only open to those who are committed to both the nation and the rule of law'. ${ }^{8}$ In contrast to Orbán and Antall, those on the left and liberals have accepted the legalcivic conception of the nation. This vision meant accepting the current state of affairs and striving to guarantee the right of the Hungarian minority to express its national consciousness, language and traditions as secured under the treaty. This dualism was a consequence of the divisions which had already existed in the interwar period (the folk writer and urban camps). Now, it is clearly discernible in two very different concepts in Hungarian politics: state building and nation building. ${ }^{9}$

\section{Fidesz and its new policy of national unity}

The first important step in building a national identity was the adoption in 2001 of the Hungarian Card (a document under the Hungarian Charter 


\section{Tadeusz Kopyś}

that granted a number of privileges to its holders from countries such as Romania, Ukraine or Serbia) and the 2004 referendum on the extension of Hungarian citizenship to all Hungarians of ethnic origin living outside Hungary. On 5 December 2004, a referendum was held in Hungary to gauge the public attitude towards the concept of granting dual citizenship to Hungarian citizens living abroad. The idea was to give Hungarians living abroad the opportunity to enjoy Hungarian rights and social benefits related to EU citizenship, as well as a sense of belonging to the Hungarian nation. Ultimately, however, the lively debate which ensued and the politics of disinformation and criticism of the referendum by left-wing parties led to a mass boycott of the referendum: only $37 \%$ of those eligible to vote took part, which made it invalid. The referendum initiative came from a nationalist group, and Fidesz adopted it mainly for tactical reasons. The referendum's motto was 'We can finally heal the wounds of Trianon'. The referendum failed because the then socialist-liberal government waged a populist counter-campaign, pretending to protect the social achievements of poor Romanian Hungarians, and people continued to fear Fidesz because they suspected that dual citizenship was simply a costly whim of the right and a ploy to gain an additional electorate for Fidesz abroad, a suspicion which was borne out later. The referendum was declared invalid, which led Fidesz to blame left-wing and liberal parties for being 'traitors to the national cause'. After the electoral defeat of the socialist party and the victory in the Hungarian parliamentary elections in 2010, Fidesz won two-thirds of the seats in parliament (the disproportionate electoral system gave the right-wing coalition $52.7 \%$ of the votes and $68 \%$ of the seats in parliament). ${ }^{10}$ When Fidesz took power again in the first session of the new parliament, it passed a dual citizenship law. Ninety years after the signing of the Treaty of Trianon, 4 June was paradoxically declared the Day of National Unity, something quite characteristic of contemporary, mainstream Hungarian nationalism. The new prime minister, Viktor Orbán, introduced the 'National Cooperation Programme' and Fidesz launched a programme of constitutional reform, lowering the requirement of a majority of four-fifths of the parliament to amend the constitution to twothirds, and consistently weakening any legal institutions that might seek to control or limit the government's actions. The main rationale for replacing the previous constitution was that it ran counter to individual rights as opposed to the interests of the national community, and therefore was unable to express 'Hungarian national values' strongly enough. ${ }^{11}$ The new government introduced a new constitution in April 2011 and its controversial provisions resulted in an avalanche of reports and comments from the press, academics, the Venice Commission, the United States, the European Parliament, NGOs and human rights defenders. This raised concerns in the European Union about human rights and the concept of the tripartite division of powers. Fidesz's electoral success violated the sacred canons of 
left-liberal consensus. The overwhelming electoral victory had a sobering effect for those who felt that history had ended with the triumph of liberal democracy. The new authorities emphasised that Hungarian problems should only be solved with the use of Hungarian methods and with due regard to the unique nature of Hungary's development.

Some analysts have claimed that the 'Trianon syndrome' is also useful for nationalist populists who want to present themselves as defenders of the nation. Few do it better than the ruling Fidesz party of Prime Minister Viktor Orbán. After 2010, the desire intensified to create a capitalist class supporting this movement, something which is an attribute of classical populists. Hence the position of Attila Antal, who classifies Orbán's policy as 'elite right-wing populism', seems to be correct. It is characterised by the fact that its politics favours the elite and the upper middle class through its social policy, while softening discontent, defending sovereignty, criticising foreigners, and intensifying the constant sense of danger or threat. ${ }^{12}$ Hence, Hungarian nationalism does not mean a reorientation towards racism, fascism or xenophobia, nor is it ethnic in a cultural or biological sense. Before the 1998 elections, Orbán's party used rhetoric that was a loose mixture of liberalism, Christian Democrat and national ideas, seeking to establish a civic Hungary based on the middle classes. Orbán rejected neoliberalism, with which he identified the then ruling coalition of socialists and liberals, proposing a homegrown version of modernisation in its place.

Easing restrictions and barriers to Hungarian citizenship led to divisions among the Hungarian diaspora into 'good Hungarians' and those who did not sympathise with Hungarian right-wing politics and policies. The granting of electoral rights to the diaspora meant that Hungary's political arena expanded beyond its borders and is now also being played out in neighbouring countries. Almost all of Orbán's important messages are based on the idea of 'national unification', which has both symbolic and literal meanings and is employed in both foreign and domestic policy. In terms of the former, the prime minister explicitly criticised Trianon, as well as the legacy of the communist system and the impact of globalisation; forces he believed were the top political issues to be addressed prior to 2010. In terms of domestic politics, 'national reunification' refers to the 'system of national cooperation' (a set of 'unconventional' policies combining statism, economic nationalism, protectionism and neoliberalism) that has proven to be an alternative to liberal democracy. ${ }^{13}$ Sharing voting rights with representatives of an external national minority is one of the most controversial tools for maintaining bonds with citizens abroad. Extending the electoral law to encompass the diaspora is important both symbolically and pragmatically. Symbolically, by making voting available to those who do not live in the country, it means recognising external citizens as fully fledged members of a political community or as political actors in their former homeland, which is still understood in terms of a state, albeit an imagined one. ${ }^{14}$ 


\section{The Eastern (Asian) turn in the conception of the Hungarian nation in the 21st century}

When assessing the issue of globalisation, the Fidesz leadership believes that nation states will prevail in the future. If we look at Asia - as the leaders of Hungary claim - there are no common actions, no common currencies - but rather both small and large countries that are doing very well. Moreover, in terms of the development of economies or states, we should also consider the development of national values since building a pan-European community ultimately leads to their erosion. On the other hand, the Jobbik party and its leader, Gábor Vona, support the idea of abandoning Eurototalism in favour of Eurasianism (linking Hungary with political and economic alliances with the great states of Asia)..$^{15}$

In June 2001, the Hungarian parliament adopted a law on the rights of national minorities, which became known as the Hungarian Charter, and which attracted the attention of both European officials and researchers working on nationalism. In Central Europe, governments including the Austrian, Croatian, Romanian and Slovakian had also passed laws that granted various forms of preferential treatment to members of their own diasporas living in other countries. The Hungarian Card is therefore an example of a nationbuilding strategy that can be defined as 'virtual nationalism'. As an alternative to the traditional concept of the nation state, it aims to include ethnically related people in the concept of the nation and to offer them a number of unique rights, a potentially controversial notion in the European Union.

Trans-sovereignty, or 'virtual nationalism', aims to create institutions that link people across national boundaries. This option abandons the idea of border changes, insists that the political community should be based on national identity without the need to create a nation state. The second Fidesz government, established in 2010, passed the Dual Citizenship Act, which is another important step in the implementation of the Hungarian trans-sovereign nation-building strategy. The law provided for citizenship on demand for those who do not live in their home country. Granting citizenship to representatives of a national minority resulted in the transformation of the definition of the national interest to include not only the interests of resident Hungarian citizens, but also the interests of those who constituted a national minority abroad. ${ }^{16}$

The act granting dual citizenship entered into force in January 2011. It gives all persons who can prove that their ancestors came from the Greater Hungary area the right to obtain Hungarian citizenship. It therefore makes it possible to obtain dual citizenship for people living outside Hungary, and there is no requirement to move to Hungary, which should apply to Hungarian minorities living in neighbouring countries. ${ }^{17}$ Shortly thereafter, an amendment to the law requested by Jobbik provided that foreigners naturalised in this way had the right to participate in elections in Hungary. Neighbouring countries reacted nervously to the new law. The Slovak authorities expressed concern 
about the lack of dialogue and cooperation with the Hungarian government in drafting its law on citizenship. The Fidesz party was founded in 1988, but did not become one of the most important parties in the country until 19982002. Especially before the 2010 elections, Orbán and Fidesz focused their policies on shaping a new concept of the Hungarian nation, with the party's elites focused on building national cohesion. Against this political framework, the subject of the Treaty of Trianon returned to the fore. A second tendency was to discredit and delegitimise the liberal side of the political scene as hostile to the people (nation).$^{18}$ Even during his first administration, Orbàn was clearly revisionist and spoke of creating an economic living space in the Carpathian basin and of taking steps to secure at least one autonomous territory for Hungarians living abroad. It seems that Fidesz did not make any revisionist demands, but the very use of slogans referring to the past, to a Greater Hungary, or at least an allusion to it, by the politicians of this party was something new for voters. It seems that the leader of Fidesz used some slogans in his programme that were taboo in Hungarian politics before 1989. An element of this rhetoric was the Lands of the Crown of Saint Stephen and, ${ }^{19}$ after 2010, the commemoration of the infamous Trianon Treaty returned. As part of their strategy to counteract internationalisation, Fidesz leaders introduced a National Unity Day (Nemzeti Összetartozás Napja) shortly after winning the elections, marking the anniversary of the Trianon peace treaty by means of a symbolic rejection of it. ${ }^{20}$

Most of the Hungarian political elite between 1989 and 2001 were aware that support for any revisionist projects (particularly any related to the revision of the 1920 borders) would be unacceptable in Europe, which was also confirmed by the poor public support for the far-right Hungarian Justice and Life Party (MIÉP). This new, one could say Hungarian, model rejects the idea of territorial revision and the repatriation of the diaspora to the homeland. This model uses EU law that places considerable emphasis on the rights of national minorities, and instead of restoring the nation state, it creates nation-centric and centre-dependent institutions that maintain and reproduce the nation beyond existing state borders. ${ }^{21}$ They do this through a myriad of support programmes for schools abroad, by providing jobs and hospitals for members of the diaspora, creating companies that enable the diaspora to grow and remain in their ancient territories (e.g. in Slovakia and Transylvania). On the path of such a development controlled from the centre - such as Budapest - Hungarian communities abroad have a chance for the first time in many decades to rebuild demographically, to arrest their assimilation and reduce internal and external migration.

From the moment of its adoption, the Hungarian Card was clearly the most coherent attempt to formulate virtual, cross-border nationalism. Anyone obtaining the card was entitled to a number of privileges in their home country. The large number of card applicants indicated that the legislation was met with a high demand. In Romania, 700,000 cards had been issued by mid-July 2003. These numbers suggest that a large part of the 
ethnic Hungarian population outside of Hungary maintains the concept of a common Hungarian nationality, despite the separation of these territories from Hungary in 1918-1920.

In the minds of the creators of the Hungarian Card, the government, supported by the right-wing Fidesz and Jobbik parties, is continuing a policy which is in line with the concept of a 'cultural nation'. This means that every Hungarian is part of the Hungarian nation, no matter where they live, providing they remain faithful to the Budapest government. Fidesz was the first political party to establish personal relations with ethnic Hungarians abroad and these networks helped Fidesz to formulate its policy in such a way that ethnically related people aboard were able to take centre stage in the new concept of the nation. Fidesz's party structures boast the largest number of Hungarians from neighbouring countries and it was these ethnic Hungarians who emphasised the need to institutionalise ties with their homeland. This was done, inter alia, by establishing the Office for Hungarians Abroad (Határon Túli Magyarok Hivatala). Moreover, other elements binding together Hungarians are the World Federation of Hungarians and the Bethlen Gábor Foundation. Fidesz was the first to formulate a comprehensive policy towards its national minority abroad, something which gave it an advantage over leftliberal opposition parties. ${ }^{22}$

After 2010, the government introduced a law allowing the Hungarian diaspora to participate in elections in Hungary. On the one hand, this is a very generous action by the government, and on the other hand, it gives Fidesz a significant advantage in the next elections. In 2014, $95 \%$ of Hungarians living abroad voted for Fidesz..$^{23}$ After 2010, Fidesz took over the role of the party of the entire Hungarian nation, and, representing Hungary and the entire nation abroad, denied this role to others. According to this theory, there is one nation, so one political option should represent it. As part of this approach to diaspora issues, however, an illustrative dualism emerged that manifested itself in two points of view on national issues: a left-wing and a right-wing one. ${ }^{24}$

This approach to national issues became an element used in gauging how representatives of individual political factions tackled some important political issues, and even those related to Hungarian foreign policy. In other words, the divisions in the assessment of national issues was in effect a division into the forces that represented the nation and those that could not, would not or did not want to represent it at all. The vision of Europe described as the Orbán model is of a 'Christian Europe of sovereign states' and an 'illiberal democracy'. Hungary's position on the future of the European Union, repeatedly expressed in many political fora, can be called the Hungarian model of the EU. The newly adopted amendment to the Basic Law of Hungary, with the obligation of the state to protect Christian culture and potential to restrict certain fundamental rights, strengthens the role of religion in the constitutional legitimacy of the concept of an ethnic nation. In this concept, the nation, as the subject of the Basic Law, is not only a community of ethnic Hungarians, but also a Christian community, which means that those who 
do not associate themselves with Christianity may also feel excluded from the nation. In this constitutional order, the state does not necessarily have to tolerate all religions, and adherents of Christianity may feel entitled to intolerance towards representatives of other religions. ${ }^{25}$

In Orbán's speech in Baile Tusnad in July 2018, the Hungarian Prime Minister raised several important aspects regarding the future of Europe and the region. Most importantly, he confirmed the need to 'build a Central Europe' where the local culture differs from that of Western Europe. In this sense, the region is more important than the entire Union. In another speech, on 26 July 2012, Orbán explained why authoritarianism is needed in treating the Hungarian malaise: 'Joining forces is not a matter of intention, but pure strength. In the case of a semi-Asian party like ours, there is no other choice'. This assessment is very similar to that of the late Imre Kertész, a Nobel laureate in literature, who argued that Hungary's misfortune was due to its inability to choose between Asia and Western Europe. Even so, religion (religions) had not influenced the shaping of the national idea in the same way as in Poland, for example. Under communism, the Roman Catholic Church was neither a symbol of national independence nor a source of protection for the Hungarian opposition.

Prime Minister Orbán is critical of the West yet remains a pragmatist at heart and appreciates the opportunities offered by the European Union to Hungary. In the eyes of many Hungarian intellectuals, what has happened in the last twenty or thirty years - since socialism turned into liberal democracy - was a success story until Fidesz took power in 2010. The country is seen as having been embraced by Putinisation, authoritarian politics and a staterun economy, which in fact leads to the belief that the country has never been truly democratic and may never shake off its legacy of selfish nationalism and paternalistic state socialism. Orbán, himself vice-president of the European People's Party, expressed his view on Europe in the following terms: 'We want to live in Europe as Hungarians'. The Fidesz leader did not present the EU as a threat to Hungary, but he also did not unconditionally support all of the ideas coming from Brussels. Since 2010, Orbán has waged a 'war of independence' against Brussels. Taking advantage of the traditional Hungarian resentment towards the great powers and the West, he successfully directed part of the Hungarian electorate against the Commission and the bureaucracy of the European Union. Even though Orbán was among the first to demand the withdrawal of Russian troops in 1989, he is now a pro-Russian politician and promoter of close cooperation with Asian states. He has put a great emphasis on national sovereignty in EU decision-making, and is also critical of EuroAtlantic relations and the United States. ${ }^{26}$ His 'soft Euroscepticism' relies on a particular critique of the West and neighbouring countries in order to achieve things which are in the national interest. Paradoxically, Orbán also strives to achieve greater integration with Hungary's EU neighbours. This affords Budapest the potential to build a 'transnational' nation and, simultaneously, greater odds that Union institutions will defend the Hungarian 
national minority. ${ }^{27}$ Naturally, the Fidesz leader is not an advocate of the open accession of its neighbours to various international bodies, as Ukraine can readily attest. When an educational act was passed in Kiev in 2017 that allegedly harmed the interests of the Hungarian national minority in Ukraine, Hungary began to block the process of Ukraine's integration with NATO.

The Hungarian vision of the European Union is ideological and should be seen in Eurosceptic and conservative terms. The main elements of this model are the concept of 'Christian democracy' or 'illiberal democracy'. The second element of the Hungarian vision of Europe and the place of the Hungarian nation in it is a 'provincial' approach to Central and Eastern Europe. It is based on an aversion to the Trianon Treaty and a recognition of the cultural diversity of Central and Eastern Europe and the Western part of the continent (alongside a radical rejection of multiculturalism). Another aspect of Budapest's activities is its immigration policy, which is similar to the policy of the German authorities in accepting ethnic Germans expelled from various Central European countries after 1945. According to Zsuzsa Csergő and James Goldgeier, if a Hungarian politician ${ }^{28}$ were to be asked what the concept of their nation's development is, they would probably answer that it is a 'Europe of the regions' with many centres of power and various forms of loyalty. Hence, for Hungarians and their diaspora in Central Europe, Budapest acts as a centre of national culture, but on the other hand, centres in Bratislava, Belgrade and Bucharest are those in the which the diaspora is loyal to the state in which they live. There are also regional centres such as Košice (Hungarian: Kassa), Kolozsvar, Nowi Sad (Hungarian: Szabadka). Such a concept of the nation and multi-level centres of sovereignty and loyalty appeared, according to some researchers, in the Middle Ages. ${ }^{29}$ Diaspora community building is similar to the nation-building process: it is about 'creating and maintaining contacts with Hungarian minority populations in the region to promote a common identity. ${ }^{30}$

The third element of the Hungarian model is the pursuit of close cooperation with Russia, Turkey, China and other Asian countries, based on intensive economic relations and the proposal to provide EU security guarantees to some member states. Ethnonationalism, referring to tribal traditions, is akin to a substitute for religion. ${ }^{31}$ The radical right (e.g. Jobbik) is decidedly anti-Israel, pro-Palestinian and anti-American. However, interestingly and perhaps uniquely amongst Hungarian political parties, it is also pro-Syrian, anti-Western, pro-Russian and pro-China. The party also advocates closer ties with other countries such as Kazakhstan. Jobbik wants to create a 'sacral alternative' for the Hungarian electorate in the form of various pre-Christian pagan cults. Neo-Turanism is, therefore, a source of the formation of new layers of national pride, a specific code (alongside runic script), one which is incomprehensible to others and legible only to Hungarians and the diaspora, it is a form of mysticism and exoticism. These traditional values found their way perfectly in the modern world because they are propagated via a number of websites: kuruc.info and barikad.hu. In turn, emerging ethnic myths such as 
Euroasianism and Turanism raise questions about how deeply they should be interpreted. Should Hungary support relations with China, or should it stand up for their Uighur and Tibetan 'relatives' oppressed by the Beijing regime? The theory of Turanism accords the role of a bridge between East and West to Hungary, filling its adherents with pride in their past, a sense of independence, and a desire to find the true nature of the nation which is poised on the border between two worlds. This eastern ethnogenesis seemed to fit perfectly with the trends prevailing in the global economy after the 2008 crisis. Prime Minister Viktor Orbán stated after 2010: 'To be powerful, a person must be proud of his national identity (...) In Europe, the Hungarians are the most western eastern nation (...) and today it is an honour to be called an oriental nation'. ${ }^{32}$

\section{Hungary within the European Union}

The fourth element in the Hungarian vision of the EU is a far-ranging pragmatism. Hungary is a moderately Eurosceptic country, with the Hungarian variant taking a very pragmatic form which exploits many of the opportunities afforded by membership of the European Union. Hungarians are one of the European nations which treat national identity as superior, as one which surpasses European identity. As many as 51\% of Hungarians rate their identification as 'Hungarian' higher than others and concomitantly this diminishes the sense of belonging to the European Union. A further $44 \%$ articulate an attachment to national traditions but also of belonging to Europe. Only $1 \%$ of the Hungarian population declares themselves as 'Europeans' above all other sources of identification. Hungarians are only somewhat proud of their national achievements as a collective (less than $50 \%$ ) but, on the other hand, they are very proud of the achievements of their athletes and artists (over 90\%). According to sociological research, the approach to European and national-Hungarian identities and the assessment of sporting success depends on the region of residence. The Hungarian government has been accused of trying to virtualise its borders, of paying only lip service to the political borders of Hungary. In fact, the Hungarian government seeks to exert its power to influence Hungarians in Romania, Slovakia and Ukraine in the political (through the participation of Hungarians abroad in Hungarian elections), cultural and educational fields. As a result, the Hungarian government has strongly supported, and continues to support, the membership of all its neighbours in the European Union.

The refugee crisis in Europe in 2015 showed, in the opinion of some observers, the intolerance of the Hungarian government. ${ }^{33}$ At the beginning of the crisis, Prime Minister Viktor Orbán stated that 'Christian culture is a unifying force for the nation'. He went on to claim that 'Hungary will either be Christian or not at all'. In another speech, in early September 2015, Orbán went further, stating that 'The Christian-national idea will regain its predominance not only in Hungary but throughout Europe' ${ }^{34}$ Christianity and religion serve as 
reference points which Orbán's brand of right-wing populism uses selectively to build its political narrative. Fidesz, once a liberal party, began to move to the right side of the political scene from the mid-1990s, openly adopting a positive attitude towards religion. Fidesz uses religious symbols and employs them alongside pre-Christian pagan traditions. This is reflected in the concept of the 'two Hungaries', two very different traditions that are derived respectively from Western Christianity and an older pagan legacy, one which dates back to the tribal period. According to the current political elite, the legendary Turul bird, a symbol of ancient, pre-Christian Hungary, is the most representative symbol of national identity, an image which gave birth to Hungary. Fidesz interprets these pre-Christian traditions within the framework of nationalism, and this ethnonationalism provides a sufficient basis for political identification as a kind of substitute religion. The crown of Saint Stephen is another powerful symbol of contemporary Hungary. Particularly noteworthy is the manner in which the authorities reconciled the worship of the "holy crown' and pagan traditions after 2010. The crown, upon its return from the USA in January 1978, was placed by the communist Hungarian authorities of the time in the National Museum, where it was just another museum exhibit. It grew in importance, however, during the first Fidesz government. In 2000, along with the sceptre, orb and coronation sword, the crown of St Stefan was transferred to the Dome Hall of the Hungarian Parliament. It has become an image and symbol of the unity of the once broken Hungarian nation. In exceptional cases, the crown is transported by boat to Esztergom, the seat of the Archbishop of Hungary (for example, it was transported on 15 August 2001, on the feast of the Assumption of the Blessed Virgin Mary). However, in March 2012, Oiuna Adigzi See-Oglu, a shaman from the Russian republic of Tuva, ${ }^{35}$ was invited to the Hungarian parliament, and who cleansed and rededicated the crown of St. Stefan in a new place in parliament. This took place despite the negative position of the Catholic church in Hungary towards neopaganism. ${ }^{36}$ In 2012, during a visit to Kazakhstan, the Hungarian governmental delegation presented their hosts with a shamanic world tree. ${ }^{37}$

Fidesz has managed to combine anti-elitism, nationalism and an antiEuropean stance with a pragmatic approach in most areas of policy, presenting a charismatic leadership that allegedly defends national interests and those of ordinary people.

Populism does not have a specific and enduring ideological content but is rather characterised by an anti-elite approach to politics that seeks to foster mass political mobilisation and mass participation in the political process. Populism, therefore, can develop any ideology which serves to unite and homogenise the nation. ${ }^{38}$ The influence of populism is also clearly discernible in Hungarian foreign policy. The current Hungarian government is pro-Russian (with the idea of the Eurasian Union backed by its coalition partner, Jobbik) and often uses history to reinforce its position towards Brussels. The apogee of this anti-EU rhetoric is the commemoration of the Hungarian freedom fighters of 1956, combined with criticism of the West, which failed to help 
Budapest fight off Soviet intervention. On 25 February 2017, Viktor Orbán declared that the ideas that led to the oppression of the 20th century had sprung up in Western minds, that both communism and National Socialism were intellectual products of the West. On the same occasion, the Minister of Human Resources, Zoltán Balog, even argued that effective and constructive dialogue between post-socialist states and Western Europe could only be established if the latter 'was willing and able to look at the sins of both communism and Nazism as a European shame'.

Hungary's growing economic dependence on Russia has contributed to a certain ambivalence towards its communist past, and the authorities have only orchestrated what might be termed 'limited de-Russification'. Since 2014, Fidesz has tried to bring the EU closer to Russia, attempting to secure Russian support for projects that the EU opposes. The best example of such actions was the controversial decision to expand the Paks nuclear power plant, which Hungary will eventually be able to implement thanks to Russian funds, despite initial opposition from the European Commission. The policy of ambiguous gestures does not make Fidesz popular in Europe either. When Hungary took over the presidency of the Council of the EU, a carpet adorned with a map of Greater Hungary greeted guests to the council building as soon as they entered. ${ }^{39}$ During the political crisis in Crimea, the conflict between Russia and Ukraine, Prime Minister Orbán came up with the idea that the Hungarian minority in Ukraine should also be able to decide for themselves and have the right to obtain Hungarian citizenship. As a result, the authorities in Budapest quickly came to be called 'Russia's Trojan Horse in the European Union'. ${ }^{40}$

Orbán has frequently stated that the timeworn political distinction between the left and the right is no longer meaningful. Fidesz has begun to see itself as the repository of national values and interests and its efforts in this regard have been greatly aided by the inability of those on the left to develop an authentic interpretation of the concept of the nation. Fidesz's political concept can be described as a mobilising form of conservatism, one aimed at strengthening solidarity and loyalty based on national identity. This ideology assumes that national issues are typically ignored or underestimated by the state and thus aims to redress the balance in order to ensure the primacy of the nation. This approach takes for granted that, in order to achieve national goals, the nation should even be superior to the state. It was only after 2002 that Fidesz managed to crystallise the party's programme around this ideology. ${ }^{41}$

From this point on, the emphasis on the nation became dominant: the nation began to be regarded as the ultimate source of legitimacy. In doing so, Fidesz scored points over its rivals for their perceived lack or insufficient development of national policy in their programmes. In contrast, Fidesz advocated a cultural interpretation of the concept of the nation under which the relationship between the state and the individual was of secondary importance: belonging to a nation and citizenship are two separate dimensions. Fidesz conservatives believe that the nation provides a more important source of legitimacy than 
that which stems from the political games played out in parliament. Fidesz has taken the position that power in the state can only be legitimised by the will of the nation..$^{42}$ A key assumption in the post-1989 concept of the Hungarian nation is that it is no longer divided and separated by the borders established after 1920. If we treat the nation as a political category, there is only one Hungarian nation: the community of Hungarian citizens who live together. If any (individually) or even all (of course, also individually) Hungarians living abroad want to become members of this national political community, there are procedures to facilitate this. Members of this community can even move to Hungary, where they can obtain Hungarian citizenship after some time.

\section{Conclusions}

The evolution of Hungarian nationalism after 1989 is closely intertwined with its national past. The 'trauma of Trianon' is felt across the political spectrum in Hungary, and Prime Minister Orbán has used these emotions over the past decade in his efforts to show Hungary as a resurgent nation and to contain migrants and the alleged 'globalist influence'. After 1989, a renaissance of national issues has also been observed in Hungary, previously a taboo subject prior to the political transformation. No political alternative (including the left) has defined its attitude to the past, memory, diaspora issues and national identity. It seems that belonging to the European Union has made it easier for the Magyars to maintain contact with their diaspora, allowing them to appeal to international political forums in the defence of Hungarians in countries such as Romania and Slovakia.

In recent years, there has also been a renaissance in Hungarian Turanism, represented especially by Jobbik, a party which is also anti-Western. Jobbik is very critical of both the international policy of the European Union or the United States. Hungary is considered a victim of Western politics, a country which, as a result of Western policy, has the largest national minority in Europe. Jobbik's politicians also strongly criticise globalism, liberalism. Therefore, the 'eastern turn' seems to be a retreat from the West. On the other hand, the migration crisis in Europe might become an obstacle for Hungarians in their attempts to foster better relations with certain Asian nations.

\section{Notes}

1 Benedict Anderson, Imagined communities. Reflections on the Origin and Spread of Nationalism, (Verso 1983), 73-77, 101-106.

2 Jeffrey C Alexander, 'Toward a Theory of Cultural Trauma', in Jeffrey C Alexander, Ron Eyerman, Bernard Giesen, Neil J Smelser, Piotr Sztompka (eds), Cultural Trauma and Collective Identity, (University of California Press 2004), 22-23.

3 Susan Brison, 'Trauma Narratives and the Remaking of the Self', in Mieke Bal, Jonathan V Crewe, Leo Spitzer (eds), Acts of memory. Cultural recall in the present, (Dartmouth College Press 1999), 39-54. 
4 Gábor Gyáni and György Kövér, Magyarország társadalomtörténete. A reformkortól a második világháborúig, (Osiris Kiadó 2004), 384.

5 Tamás L Vizi, A sérelmi politizálástól a nemzeti összetartozásig. Trianon, revizió, határkérdés, nemzetegyesítés 1920-2010, (CEPOLITI Kiadó 2016), 10-11.

6 István Mészáros, 'Klebelsberg Kunó, az iskolareformer', in István Zombori (ed), Gróf Klebelsberg Kunó emlékezete, (Gróf Klebelsberg Kuno Alapítvány 1995), 49-50.

7 Gergely Egedy, 'Conservativism and Nation-Models in Hungary', (2013), 4, Hungarian Review, 3, 68-72.

8 József Antall, 'Az MDF legyen középpárt' in Modell és valóság, (Budapest 1994), vol II, 9-10.

9 Egedy, (n 7), 71.

10 Miklós Bankuti, Gábor Halmai, Kim Scheppele, 'Disabling the constitution', (2012), 23, Journal of Democracy, 3, 139-140.

11 Gyula Tellér, Rendszer-e a rendszerváltás rendszere?, (2009), 54, Nagyvilág, 11, 982-987.

12 Attila Antal, A populista demokrácia természete, (Napvilag Kiadó 2017), 246-249.

13 Umut Korkut, Liberalization Challenges in Hungary: Elitism, Progressivism, and Populism, (Palgrave 2012), 172-175.

14 Peter J Spiró, 'Perfecting Political Diaspora', (2006), 81, New York University Law Review, 1, 102-155.

15 Mark Bassin, Gonzalo Pozo, The Politics of Eurasianism: Identity, Popular Culture and Russia's Foreign, (Rowman and Littlefield 2017), 254-256.

16 Zsuzsa Csergö and James M Goldgeier, 'The European Union, the PostCommunist World and the Shaping of the National Agendas', http://aei.pitt.edu/ id/eprint/3004 accessed 12 May 2020.

17 Andreas Koob, Holger Marcks, Magdalena Marsovszky, 'Größenwahn im Karpatenbecken. Die ungarische Rechte und ihr Blick nach Außen', in Mit Pfeil, Kreuz und Krone. Nationalismus und autoritäre Krisenbewältigung in Ungarn, (Unrast Verlag 2013), 158-159.

18 Lászlo L Balogh, 'Trianon-Stationen und Statuen des Schmerzes', in Harald Dionys Gröller and Harald Heppner (ed), Die Pariser Vororte-Verträge im Spiegel der Öffentlichkeit, (Transkulturelle Forschungen an den Österreich-Bibliotheken im Ausland 2013), 61-63.

19 Koob, Marcks, Marsovszky, (n 17), 155-195.

20 Magdalena Marsovszky, 'Geschlossene Gesellschaft. Zu den ideologischen Hintergründen der völkischen Entwicklung in Ungarn', in Andreas Koob, Holger Marck, Magdalena Marsovszky (eds), Mit Pfeil, Kreuz und Krone. Nationalismus und autoritäre Krisenbewältigung in Ungarn, (Unrast Verlag 2013), 13-57.

21 Zsuzsa Csergő and James M Goldgeier, 'Nationalist Strategies and European Integration', (2004), 2, Perspectives on Politics, 1, 21-37.

22 Nándor Bárdi, 'A Külhoni Magyarok és a Magyarországi Kormányzati Politikák', in Ervin Gömbös (ed), A Kisebbségek Jövöje a Globalizálódó Világban, (Magyar ENSZ Társaság 2016), 21-34.

23 http://magyarforum.hu/cikk/231/65-orszag-magyarjai-igenyeltek-a-kettos-allam polgarsagot accessed 23 May 2020.

24 Ildiko Szabó, 'A nemzet fogalmi konstrukciója a Fidesz diskurzusaiban 1998 es 2006 között', (2007), 16, Politikatudomány Szemle, 3, 145-150. 


\section{Tadeusz Kopyś}

25 'Minden magyar a turulba születik' [All Hungarian Are Born Into the Turul Bird] Népszabadság, (Budapest, 29 September 2012).

26 Péter Tölgyessy, 'A Fidesz és a magyar politika lehetséges új iránya', in Zsolt Bod and András Körösényi (ed), Van irány? Trendek a magyar politikában, (Hungarian Acedemy od Sciences Press 2012), 332-337.

27 After the 2014 European Parliamentary elections, the Hungarian nation is also represented by Hungarians from Romania and Slovakia, with the election of László Tőkés from Transylvania and László Gubík from Slovakia. The creation of a unified Hungarian nation became a reality.

28 Of course, the answer we get to this question will depend on the political orientation of the given politician.

29 Zsuzsa Csengő and James Goldgeier, 'Nationalist Strategies and European Integration', 27, www.researchgate.net/publication/231890449_Nationalist_ Strategies_and_European_Integration accessed 31 May 2020.

30 Ibid., 4.

31 Ibid., 2-3.

32 'Hungary ready to open a new chapter of Hungarian-Turk cooperation', www. kormany. hu/hu/a-miniszterelnok/hirek/magyarorszag-keszen-all-a-magyar-turkegyuttmukodes-uj-fejezetenek-megnyitasara accessed 26 May 2020.

33 As Prime Minister Orbán explained, 'Our [migration T K] policy is to help where there is trouble, not to bring trouble to Europe (...) We believe that large numbers of Muslims will necessarily lead to the emergence of parallel societies, because Christian and Muslim communities will never come together'. Orbán believed that the elite of the 'European empire' was ruled by bureaucrats who were not elected by anyone. According to Orbán, these elites are detached from their national roots. For more, see www.tvp.info/35519891/viktor-orbn-o-przyjmowaniu-uchodzcowpostrzegamy-ich-jako-muzulmanskich-najezdzcow accessed 23 May 2020.

34 András Bozóki and Zoltán Ádám, 'State and Faith: Right-wing Populism and Nationalized Religion in Hungary', (2016), 1, East European Journal of Society and Politics, 2, 98-122.

35 The Republic of Tuva borders Mongolia and is therefore far from the ancestral homeland of the Finno-Ugric peoples, that is, the eastern slopes of the Urals and the Khanty-Mansi Autonomous Okrug.

36 The mages known as taltós, who practised their rites until the 19th century, can be considered remnants of shamanism in Hungary. The interest in this side of the Hungarian tradition dating back to the times of the Magyar migrations began in the 18th century, with the first Hungarian scholars travelling to the Turkish countries and when the first non-scientific research into the anthropology and ethnology of the Magyars took place. The first researcher to tackle the subject of shamans was Vilmos Diószegi, who dealt with this subject in the 1950s in the then Soviet Union.

37 The World Tree occurs in various variants, even in Siberia itself, e.g. Tungusians believe that there are as many world trees as there are main worlds. The concept of the world according to Hungarian shamanism is also different - whilst it is presented in the form of a tree which is common enough in Europe, in contrast to the rest of the continent, the division of the world is vertical (eastern world evil, western world - good). Wiesław Bator, Drzewo sięgajace nieba: szamanizm $i$ dyfuzjonizm w węgierskiej baśni magicznej, (Nomos 1987). 
38 Nadia Urbinati, Democracy Disfigured. Opinion, Truth, and the People, (Harvard University Press 2014), 108-110.

39 In December 2016, during a meeting of the Hungarian Diaspora Council, he spoke about the fact that all parts of the Hungarian nation, once 'broken by the dictates of Trianon', had finally found themselves. After: Dominik Héjj, 'Węgry 2010-2017. Ile jest populizmu w reżimie Viktora Orbána?', in Filipa Pierzchalski and Bartosz Rydliński (eds), Autorytarny populizm w XXI wieku. Krytyczna rekonstrukcja, (Dom Wydawniczy Elipsa), 139.

40 www.atlanticcouncil.org/in-depth-research-reports/report/kremlin-trojan-horses accessed 2 March 2020.

41 In 2002, after losing the elections, Fidesz reacted to the defeat by turning to more radical populism. Its nationalism also became more pronounced and more clearly directed against the left. In his famous speech after losing in the first round, Orbán said: 'For us, our family, our children, our human dignity, our freedom, our faith and our country are important things in life (...). Now we must defend them (...). We Hungarians, we have nowhere to withdraw. Our opponents have revealed their true nature (...). If we do not stand firmly behind the ideas we believe in, Hungary will become their playground. Let us not allow it (...). This nation, this country is our homeland'. See József Debreczeni, Arcmás, (Noran-Libro Kiadó 2009), 299.

42 Umut Korkut, Liberalisation Challenges in Hungary: Elitism, Progressivism and Populism, (Palgrave 2012), 162-168. 


\title{
11 Between the past and the future \\ Eurosceptic political parties and the EU integration of Serbia ${ }^{1}$
}

\author{
Natasza Styczyńska and Haris Dajč
}

\section{Introduction}

It is estimated that the vast majority of the trade with and direct investment in Serbia comes from European Union (EU) member states; ${ }^{2}$ nevertheless, since the start of the accession process, Serbia has been perceived as one of the most Eurosceptic countries in the post-Yugoslav space. Anti-EU attitudes are fuelled by nationalism, but also by rising populism and anti-establishment rhetoric. Although Serbia's application for EU membership was submitted in December 2009, the accession negotiations only began in 2014. Even though the application for EU membership 'was the result of consensus among political parties that make up the ruling pro-European coalition as well as some opposition parties that support EU membership bid', ${ }^{3}$ one can observe a significant number of political parties that oppose EU accession. Analysing Serbia's approach to the EU and European integration, we need to take into consideration the historical background. One of the most significant issues that is present in both the public and political discourse, not only in the context of EU integration, is the status of Kosovo and the evaluation of the 1999 NATO intervention in Serbia. The political arena is divided between the advocates of 'direction West' and their adversaries, who not only promote an anti-EU stance, but also the need to strengthen ties with Russia and economic cooperation with China. Both attitudes are embedded in the past and make great use of modern and contemporary history to motivate and justify their claims. While the democratic transition in the post-communist states of Eastern Europe started right after the collapse of the Iron Curtain, the postYugoslav space, and Serbia in particular, were affected by an ongoing internal conflict and an unstable neighbourhood setting.

Already back in 2012, the EU Commissioner for Enlargement, Stefan Fuele, underlined the fact that while the EU expected the normalisation of relations between Serbia and Kosovo, the recognition of Kosovo was not a precondition for the eventual EU accession of Serbia. ${ }^{4}$ However, many political parties in Serbia claim that Kosovo would not have been able to declare independence without support from the EU, arguing that 'double standards' are applied with regard to the self-determination of European nations. This 
is why the issue of Kosovo, combined with nationalism, remains one of the crucial sources of anti-EU attitudes.

The main aim of this chapter is to identify and analyse the stances of Eurosceptic parliamentary political parties towards Serbian membership of the EU, keeping in mind that the national context and historical background may determine their arguments and stances on EU integration as well as the perception of the European project as such. Most of the political parties that oppose EU integration belong to the family of populist, radical right parties that perceive the European Union as a danger to the national sovereignty. Interestingly enough, one of the anti-EU parties is located on the left side of the political spectrum, combining left-wing populism and nationalism with Euroscepticism.

In most EU member states, Eurosceptic parties are rather minor actors with limited impact on policy making and government. The hard Eurosceptics that reject the EU are located on the fringes of politics. In contrast, the Serbian Radical Party 'was the largest party in the parliament that resolutely opposed Serbian EU membership'. ${ }^{5}$ This is also due to the fact that European issues were 'very salient in Serbia, which was particularly pronounced during the 2008 general election, when European integration was the single most important topic, due to the EU's position on Kosovo'. ${ }^{6}$ This is why, in analysing the Serbian case, we need to take into account specific national and historical contexts that 'affect the way in which a party may choose to debate or/and politicise the question of Europe'?

The research presented in this chapter is based on the qualitative content analysis of the party manifestos of selected parliamentary parties, given that our main aim is to outline the stances of relevant political parties since the 2013 opening of accession negotiations between the EU and Serbia.

The chapter is organised as follows. The first part presents the general background and historical context, while the second part provides an overview of the main actors - parliamentary political parties that oppose EU integration. Finally, the last part of the chapter analyses the parties' manifestos and classifies their stances before drawing some final conclusions.

\section{From the dissolution of Yugoslavia to negotiating EU membership: the historical background}

Serbian society became intoxicated with rising nationalism in the late 1980s, as the new leader of Serbia, Slobodan Milošević, appeared on the political scene as a populist and received the support of most of society in 1987. The ideological foundation of the former communist party that he rebranded as the Socialist Party of Serbia (SPS) was a combination of nationalism and economic and social egalitarianism that had been strongly embedded in the legacy of Serbian radical politicians since the late 19th century. The postYugoslav region was marked by the last war on European soil in the 20th century, one that had destructive consequences for the societies of the former 
republics. Political elites in Serbia encouraged nationalism, while the process of consolidating democracy was marginalised as a result of inter-ethnic conflicts and the plundering of the state. ${ }^{8}$ As Serbia experienced one of the highest cases of hyperinflation and some of the harshest UN sanctions ever imposed, the political elite in Serbia did not want to accept responsibility for the misery experienced by society, choosing to blame foreign factors instead. This narrative had a fertile ground as previous myths of the 'Allied betrayal' from the First and Second World Wars were popular in Serbian society, especially among nationalists. The EU, the USA and the Vatican were blamed for the collapse of Yugoslavia and most of the misfortunes that had fallen upon Serbia. That narrative remained strong among Milošević and his allies, as well as among a part of the conservative opposition. The post-2000 period marked a turning point in Serbia - after Milošević's regime was toppled in October 2000, the consolidation of electoral democracy and the development of the capitalist market began with the new Prime Minister, Zoran Đinđić, from the Democratic Party (DS). ${ }^{9}$ The reforms initiated were violently broken off on 12 March 2003 as a result of the assassination of a reformist Prime Minister whose main objective was to put Serbia on the path to EU membership. Following the debacle of authoritarianism, wars, international isolation, defeats, and economic collapse, in 2000, Serbia had managed to overthrow Milošević, but the ideological matrix and the national-populist platform survived and the deep state managed to slow down and eventually stop the reforms of the assassinated Prime Minister in 2003. Since then, no other politician has strongly advocated EU integration. The leading politicians since 2003 have been the following: 1) Vojislav Koštunica of the Democratic Party of Serbia (DSS), who openly turned into a strong Eurosceptic after the declaration of Kosovo independence in 2008; and 2) Boris Tadić of Đinđić's former party, for whom EU integration was nominally a priority but who, nonetheless, continued to pursue a nationalist policy towards Serbia's neighbours. He also restored one of the leading protagonists of the Milošević regime - Ivica Dačić from the SPS. The latter was the Prime Minister from 2012 to 2014, when a new party - the Serbian Progressive Party (SNS) became the strongest political force. The SNS and the SPS have played an important role because, in all governing coalitions since 2012, they have managed to include both soft and hard Eurosceptic parties for which the issue of Kosovo was at the top of the agenda.

In 2013, the governments of Serbia and Kosovo signed the Brussels Agreement, considered to be a major step towards normalising relations between these countries. Moreover, this EU facilitated agreement enabled the start of EU accession talks with Serbia. So far, 18 out of 35 chapters have been opened and are undergoing negotiations.

Nevertheless, the issue of Kosovo's status continues to divide the Serbian political arena and public opinion. In that context, Russia is presented as a supporter of Serbia's Kosovo policy, especially in the UN Security Council ${ }^{10}$ in contrast to the EU that does not speak with one voice (5 out of 27 members 
have not recognised the independence of Kosovo). President Vučić is believed to "play the Russia card as an offset to the EU and US influence in the regiona source of leverage in a highly asymmetrical relationship" ${ }^{11}$ although his SNS party has officially taken a pro-European stance.

\section{Serbian party-based Euroscepticism}

Although Euroscepticism is widely used as a political label in the public and media discourse, the phenomenon is multidimensional and difficult to classify. In general, we may say that Euroscepticism is associated with opposition to European integration and criticism of the EU. ${ }^{12}$ One of the best known typologies of party-based Euroscepticism was proposed by Szczerbiak and Taggart. ${ }^{13}$ According to their understanding of the phenomenon, there are two main critical positions towards the European Union and European integration: 'hard' and 'soft' Euroscepticism. ${ }^{14}$ Hard Eurosceptics perceive the EU as a threat and call for the withdrawal from the EU or for the termination of the process of EU integration in the case of candidate countries. ${ }^{15}$ Soft Eurosceptics do not object to the European project in general, but voice 'concerns on one (or a number) of policy areas which leads to the expression of qualified oppositions to the EU, or where there is a sense that "national interest" is currently at odds with the EU trajectory'. ${ }^{16}$ Euroscepticism is also more visible on the right side of the political arena, due to its natural symbiosis with elements of nationalist ideology, which 'insists on cultural and economic protectionism'. ${ }^{17}$ On the other hand, researchers have noticed that Euroscepticism can be observed as a common denominator for both radical right-wing and radical left-wing parties that use nationalism as their ideology. Halikiopoulou, Nanou and Vasilopoulou claim that EU integration can be seen as a 'threat to the nation' which the right wing understands in the ethnic terms, while the left wing in civic terms ${ }^{18}$. As mentioned before, the motivation behind Euroscepticism is very much dependent on the national context, and the attitudes of political parties towards integration may not be directly linked to the EU integration process. In this vein, Marko Stojic argues that the stances of parties in Serbia towards EU membership 'are complex, multifaceted and dynamic categories that are directly related to the legacy of the post-Yugoslav conflicts, particularly the issues of the Kosovo status, and the role of the EU and its key member states'. ${ }^{19}$

In the case of Serbia, we have identified soft and hard Eurosceptic actors on both the right and the left side of the spectrum; however, the right-wing criticism of the EU and the prospect of enlargement is predominant. Since the 2013 Brussels Agreement and the opening of the accession negotiations, Serbia has had four parliamentary elections. Our analysis covers the parties that were represented in the parliament in the governments of Ivica Dačić (2012-2014), Aleksandar Vučić (2014-2016) and Ana Brnabić (2016-2020).

The only party that was active during all three analysed terms was the left-wing nationalist Movement of Socialists (Pokret Socijalista), which was 
established in 2008 and has been led by Aleksandar Vulin since its formation. ${ }^{20}$ Before the 2012 elections, the party was part of the coalition led by the Serbian Progressive Party (SNS). What makes this coalition interesting is its catch-all nature - it consists of left and right-wing parties, often with completely opposing stances on foreign policy and the European integration of Serbia. ${ }^{21}$

Among the right-wing parties, we have identified both newcomers, such as the movement Enough is Enough (DJB), and established parties like the Democratic Party of Serbia or the Serbian Radical Party. The latter were much more influential until the internal disagreement over the ratification of the Stabilisation and Association Agreement (SAA) in 2008, which resulted in the creation of a new right-wing party - the Serbian Progressive Party (SNS) led by Tomislav Nikolić and Aleksandar Vučić, previously the second and the third men of the Serbian Radical Party. According to Bandović and Marko Vujačić, this event 'marked one of the biggest changes in Serbian politics since the introduction of party pluralism in 1990', ${ }^{22}$ as the 'split of the SRS into two factions and the formation of the SNS were a direct corollary of the EU integration process ${ }^{23}$. Since then, the Serbian Radical Party has remained hard-line nationalistic and anti-European, advocating the immediate cessation of the candidacy talks, ${ }^{24}$ while the pro-European members migrated to the SNS. Another reason for the exodus of former radical party members to the newly established SNS was their frustration with the fact that they had been runners-up in all major elections since 2000 and had remained in the opposition ever since. That reason might be a more important factor in the rapid rise in membership of the new party.

The Democratic Party of Serbia (DSS) used to be an important political actor, especially during the transformation period and the toppling of Milošević's regime, as it was able to attract the sufficient number of nationalist and conservative voters needed to overthrow his rule. ${ }^{25}$ Pro-European at the beginning, the party officially changed its attitudes after the declaration of the independence of Kosovo, which was recognised by most EU member states in February $2008 .{ }^{26}$ However, the DSS had changed its stance towards the EU as early as 2001, after its chairman Vojislav Koštunica, the then President of the Federal Republic of Yugoslavia, clashed with the reformist Prime Minister Zoran Đinđić. The clash resulted in former nationalist and conservative political actors, as well as the non-dismantled part of the Milošević elite, joining Koštunica's circle, providing a justification for demonising the reforms of PM Zoran Đinđić that had a very strong EU integration agenda.

The Democratic Party of Serbia (DSS), although playing a minor part in the political arena and elections since 2012, has remained one of the most important, as most of its former members established new Eurosceptic parties on the right of the political spectrum.

The Serbian People's Party was established in 2014 and is regarded as Eurosceptic, nationalist and Russophile, pointing at Russia as the 'most relevant economic and political partner'. ${ }^{27}$ The party strongly advocates the 
protection of Serbian interests in Kosovo and the Republic of Srpska. Enough is Enough was first established in 2014 as a political association, while it is currently a political party that is a member of the European Conservatives and Reformists Party, a pan-European Eurosceptic party. ${ }^{28}$ Furthermore, the Dveri party started as a civic movement and has since the beginning propagated nationalist and right-wing postulates. Dveri opposes the independence of Kosovo and is an openly homophobic organisation. ${ }^{29}$ The party is also known for its anti-migration stances, criticising the Vučić government for its policy on immigration. ${ }^{30}$

The 2012 parliamentary elections were overshadowed by the presidential elections, as for the first time since 1992, parliamentary, local and presidential elections were organised at the same time. The outcome of the elections was beneficial for the newly established SNS (see Table 11.1), as former veteran radical Tomislav Nikolić became President, while Ivica Dačić from the Socialist Party of Serbia (SPS) ${ }^{31}$ became the new Prime Minister. The coalition Pokrenimo Srbiju that was led by the SNS gathered together a broad spectrum of parties that for the first time became part of Parliament, such

Table 11.1 Outcomes of parliamentary elections in Serbia (Eurosceptic parties)

\begin{tabular}{|c|c|c|c|}
\hline Political party & $\begin{array}{l}2012 \text { Parliamentary } \\
\text { elections }\end{array}$ & $\begin{array}{l}2014 \\
\text { Parliamentary } \\
\text { elections }\end{array}$ & $\begin{array}{l}2016 \\
\text { Parliamentary } \\
\text { elections }\end{array}$ \\
\hline $\begin{array}{l}\text { Movement of Socialists } \\
\text { Pokret Socijalista } \\
\text { (PS) }\end{array}$ & $\begin{array}{l}\text { Part of the SNS-led } \\
\text { coalition } 24.05 \%\end{array}$ & $\begin{array}{l}\text { Part of the } \\
\text { SNS-led } \\
\text { coalition } \\
48.35 \%\end{array}$ & $\begin{array}{l}\text { Part of the SNS- } \\
\text { led coalition } \\
48.25 \%\end{array}$ \\
\hline $\begin{array}{l}\text { Democratic Party of } \\
\text { Serbia } \\
\text { Demokratska } \\
\text { Stranka Srbije (DSS) }\end{array}$ & $6.99 \%$ & - & $5.04 \%$ \\
\hline $\begin{array}{l}\text { Serbian People's Party } \\
\text { Srpska narodna } \\
\text { partija (SNP) }\end{array}$ & - & - & $\begin{array}{c}\text { Part of the SNS- } \\
\text { led coalition }\end{array}$ \\
\hline $\begin{array}{l}\text { Independent DSS } \\
\text { Samostalni DSS (S } \\
\text { DSS) }\end{array}$ & - & - & $\begin{array}{l}\text { Part of the SNS- } \\
\text { led coalition }\end{array}$ \\
\hline $\begin{array}{l}\text { Serbian Radical Party } \\
\text { Srpska radikalna } \\
\text { Stranka (SRS) }\end{array}$ & - & - & $8.10 \%$ \\
\hline $\begin{array}{l}\text { Enough is Enough } \\
\text { Dosta je bilo (DJB) }\end{array}$ & - & - & $6.02 \%$ \\
\hline $\begin{array}{l}\text { Dveri (Srpski pokret } \\
\text { Dveri) }\end{array}$ & - & - & $\begin{array}{l}\text { in coalition with } \\
\text { the Democratic } \\
\text { Party of Serbia }\end{array}$ \\
\hline
\end{tabular}


as the Movement of Socialists (PS). This party, although marginal in size, has remained part of every government formed since 2012, despite retaining its Eurosceptic stance which made it the only left-wing parliamentary party that was Eurosceptic. The PS's chairman and founder, Aleksandar Vulin, was once a protégée of Mirjana Marković, the widow of Slobodan Milošević, and a member of her party Jugoslav Left (Jugoslovenska Levica). Vulin became a member of parliament in 2012, as the PS won only one parliamentary seat at the elections. However, in the 2014 and 2016 elections, the party won two more seats. ${ }^{32}$ Nonetheless, the only well-established Eurosceptic party in the National Assembly in 2012 was Vojislav Koštunica's DSS, which remained in the opposition. Koštunica's party failed to enter Parliament in 2014, which led to Koštunica's resignation but also to the rise of new Eurosceptic political parties that became part of the Parliament after the 2016 elections.

The 2014 elections saw the switch between the PM and the Deputy PM, hence Aleksandar Vučić of the SNS became the PM while Ivica Dačić of the SPS became the First Deputy. Apart from the mandatory presence of national minority parties, only four political party lists remained in the Parliament. One of the most important results was that once well-established political parties, such as Vojsilav Koštunica's DSS, which was the flagship of Euroscepticism among right-wing parties, failed to pass the 5\% threshold. As the result of that failure, the following political parties were founded by 'former DSS renegades': the Serbian People's Party (SNP) established by the former vice president of the DSS, Nenad Popović, and the Independent Democratic Party of Serbia (Samostalni DSS). Both of those parties became part of the new Parliamentary majority (see Table 11.1) and the government following the 2016 elections, the former having established itself as strongly Eurosceptic despite being in the governing coalition that put EU integration at the top of its list of priorities.

The next parliamentary elections were held in 2016, with PM Aleksandar Vučić arguing that elections needed to be organised two years earlier, so that Serbia could have four more years of stability and so that he could bring Serbia closer to joining the EU. ${ }^{33}$ However, Serbia seems no closer to the EU four years later. What is more, the 2016 elections are very interesting as they gave life to new Eurosceptic parliamentary parties, both within the government and the opposition (see Table 11.1). Of all the 'veteran' parties that were part of the Parliament in 2014, only the PS kept its seats in 2016, while all other parties that passed the 5\% threshold had not been present in the Parliament in the period 2014-2016. All of them, except for PS, belonged to the right-wing end of the spectrum, while only Enough is Enough (DJB) was a catch-all populist party.

Based on the analysed material and existing literature, we argue that the new Eurosceptic parties could not only be divided into hard and soft Eurosceptics, but also according to the time of their establishment. Therefore, based on that criterion, we could divide them into two groups: 1) the ones that 
were established in the 20th century; and 2) the ones that were established in the 2010s. The first 'veteran' group includes the Democratic Party of Serbia, the Serbian Radical Party and Dveri, while the other one includes Enough is Enough, the Serbian People's Party and the Independent DSS.

\section{'Yes to Europe, No to the EU'34 - EU integration in party manifestos $^{35}$}

The qualitative analysis of the official documents of political parties allows us to assess which issues are important for the selected political parties and which are intentionally pushed aside. Although European integration and the European Union are not at the top of the political agenda in Serbia, parties present their stance and arguments on this subject in their official programmes. According to the 'silence theory', political parties appropriate some issues that are present in the public discourse, as a result of which each party can 'occupy' a part of the discourse and grant itself a label that helps to consolidate the electorate. ${ }^{36}$ In the analysed case, we are interested in Eurosceptic voices and their motivation - both the 'hard' ones that reject EU integration and the 'soft' ones that voice criticism but do not completely exclude the possibility of Serbia joining the EU in the future.

While analysing the collected material, we strived to assess whether the parties were in favour or against the EU integration of Serbia, what their arguments were, as well as whether there were any potential conditions (conditional support for EU integration). As Euroscepticism is often linked with nationalism, we were also interested in discovering whether certain nationalist elements were visible, and to what extent nationalism influenced the stance towards the EU.

Serbian Eurosceptic parties that have been present in the parliament since the opening of accession negotiations can be divided into 'hard' and 'soft' Eurosceptics. The first category includes the Movement of Socialists (PS), Enough is Enough and the Independent DSS. Dveri, the Democratic Party of Serbia (DSS), the Serbian People's Party (SNP) and the Serbian Radical Party (SRS) can be labelled as 'hard' Eurosceptics that call for the immediate suspension of accession negotiations with the EU. In the last analysed term (2016-2020), all seven Eurosceptic parties were represented.

The PS and the Independent DSS were part of the SNS-led coalition that had the majority of seats in the parliament, while Enough is Enough was an opposition party. Overall, the composition of the Serbian parliament was pro-European, although the hard Eurosceptics were present and their voice was widely heard.

What all 'soft' Eurosceptic parties have in common is that they pay less attention to the European Union and European integration in their political manifestos compared to 'hard' Eurosceptic parties. The Movement of Socialists puts more emphasis on anti-NATO rhetoric and geopolitical issues, including international relations: 
The essence of the struggle of the PS, as the only fighting left, is the fight against injustice, and injustice is being done to the Serbian people today like nowhere else in the world. No other nation in the world, in the past and in this century, has experienced so many lies about it being accepted as the truth.

No other nation feels that a large and important part of the state has been taken away from it and that recognition and satisfaction are being asked of it, which diminishes it. No other nation in the world has been bombed by NATO. No other nation has to fear that the greater and more powerful will constantly set all new conditions for it, and threaten to regulate its life in its country, and the size of its country. The PS opposes Serbia's entry into NATO! ${ }^{37}$

The PS places a special emphasis on cooperation with Russia, which is considered a more appropriate partner for economic and political cooperation. Overall, there is little mention of the EU as such and this also might be due to the fact that the PS was a member of the pro-EU government conducting accession talks.

The programme of the Independent Democratic Party of Serbia has no direct mention of the EU or European integration, but it does talk of the need for 'political neutrality' of Serbia and points out that 'every renunciation of the national sovereignty of Serbia in favour of supranational structures represents a danger to the freedom of citizens and a democratic order' ${ }^{38}$ Similarly to the Independent DSS, Enough is Enough focuses rather on the self-sufficiency of Serbia, emphasising that

the approximation to the European Union and cooperation with the European Union member states is a means, not an end. Cooperation with Russia, China and all other countries in the world is a means, not an end. All these countries have their own interests and are actively working on achieving and defending them (...) And they are not, nor will they ever be, our guardians or parents. ${ }^{39}$

More detailed stances on the European Union and on the European integration of Serbia can be found in the manifestos of the parties identified as 'hard' Eurosceptics. In the programme of the DSS, the party's stance towards EU integration and the EU is elaborated under the title Principles of political neutrality of Serbia. The European Union is not only seen as a danger to the Serbian economy but also to Serbian identity:

Serbia is endangered today. The state, its territory, constitutional order, economy, the development of the country, demography, as well as moral and traditional values are endangered. The current relationship of the European Union with Serbia is the main cause of the state, national and economic crisis in Serbia. ${ }^{40}$ 
The European Union is seen as the promoter of the independence of Kosovo, which the DSS cannot accept under any condition. The manifesto states that the EU

has taken on the role of the bearer of building and creating a new state of Kosovo on the territory of Serbia. And more than that, the European Union has become the main advocate of Serbia's blackmail policy, taking the position that European integration is directly related to the establishment of normal good-neighbourly, and in fact interstate, relations between Serbia and Kosovo. In other words, the European Union has set the break-up of Serbia as the most important condition for the continuation of European integration. ${ }^{41}$

In a similar vein, the radical right Dveri blames the EU for the economic failure of Serbia, but also for the independence of Kosovo. Under section Out of the EU and into the Alliance with Russia, the party presents its postulates regarding foreign policy and its stance towards the EU:

For more than 15 years, we have been on a disastrous path to the EU at any national cost. During that time, we have lost over half a million citizens, our production and economy have been destroyed, and Serbia has become an economic and political colony of those who bombed us in 1999. At that EU dead end, we are required to legally recognise Kosovo, allow the import of GMO food, impose sanctions on Russia and join NATO, then to break up the family and hand over the last natural and economic resources. ${ }^{42}$

In the same section, Dveri suggested that their first step would be to terminate Serbia's EU accession negotiations and turn to cooperation with Russia and other non-EU countries.

The independence of Kosovo and nationalism are also one of the most visible driving factors for criticism of the EU by the Serbian Radical Party. The SRS is the longest standing Eurosceptic party in Serbia, led by a controversial politician, Vojislav Šešelj. ${ }^{43}$ In their party programme, the SRS still advocates the creation of a 'Greater Serbia' that would include most of Croatia and Bosnia and Herzegovina. Their stance towards the EU has remained hard Eurosceptic, as the party 'opposes Serbia's entry into the European Union' and is 'in favour of Eurasian integration and comprehensive cooperation with the Russian Federation, China and other friendly countries'. ${ }^{44}$ They reject EU accession because they believe that the EU's 'leading member states are financiers and promoters of the self-proclaimed independence of the southern Serbian province - Kosovo and Metohija', ${ }^{45}$

Interestingly, the Serbian People's Party emphasises the 'principles of Euroscepticism ${ }^{46}$ as their main stance towards EU integration. The party underlines that Serbia is part of Europe and has long-lasting cultural, 
economic and political ties with most European countries. That is why the party is not anti-European, but anti-EU which in consequence means that the SNP 'is against Serbia's accession to the European Union because rational reasons indicate that it is not in our economic and political interest'. ${ }^{47}$ The possibility of a referendum is also mentioned, as the party wants to appeal to the people/citizens of Serbia.

\section{Conclusions}

Euroscepticism should be analysed within the context of nation states, as the historical background influences the way in which the EU and European integration are framed and debated. In the case of post-communist countries, Eurosceptic attitudes may be caused by disappointment with the transition, or with European integration as such. Countries or social groups that successfully managed to make it through the transformation period provided stronger support to European integration and the EU than those that were faced with greater difficulties. The aftermath of the dissolution of Yugoslavia, the 1999 Kosovo war and related NATO intervention and, most importantly, the declaration of the independence of Kosovo in 2008, are the internal factors that cannot be overlooked in analysing the Serbian political arena and the European integration of Serbia.

With regard to the Eurosceptic actors, we can clearly see a division between 'soft' and 'hard' Eurosceptics, the latter being mainly motivated by nationalism. Similarly to the post-communist new member states, hard Eurosceptics perceive the European Union as a threat to both identity and economy. The $\mathrm{EU}$ is portrayed as the supranational power that imposes its solutions without consultation, i.e. as a source of dominance and oppression. Anti-EU stances go hand in hand with the denial of the independence of Kosovo, which is seen as an integral part of Serbia and an important basis for identity construction. The question of the alternative to the process of European integration remains open - the Democratic Party of Serbia advocates 'political neutrality of Serbia', while other hard Eurosceptic parties like Dveri or the Serbian Radical Party point at Russia as the most important political and economic ally.

Interestingly, the voice of 'soft' Eurosceptic parties is not often heard and their political programmes tend to avoid any discussion of EU integration. This seems to be caused by the fact that the PS and the Independent DSS are part of the governing SNS-led coalition. As already noted by Stojić, who analysed Serbian political parties until 2011, Serbian parties focus on 'membership in the EU only, not the substance of European integration', as they 'appear to view the EU solely in terms of its policy towards Serbia and subsequently formed stances on EU membership' ${ }^{48}$ Even now, when accession negotiations are ongoing, we will not find any stances towards the European Union or the future of Europe in these parties' documents. 
There is one more characteristic issue that makes Serbian Euroscepticism stand out, even though similar trends have already been observed in some new member states (particularly Bulgaria). While in post-communist Eastern European countries (like Poland) EU integration was driven by economic interests as well as by the notion of the 'return to Europe', ${ }^{49}$ in Serbia EU integration seems to be motivated by more pragmatic arguments. Clientelism and political opportunism are even more important as they seem to be the leading motives for parties opposing EU integration to suppress their stances in order to join the government that publicly embraces EU integration as one of its priorities. This strategy may also be a result of the catch-all nature of parties that try to meet the expectations of the maximum number of voters, as the opinion polls show that there is no consensus regarding EU integration, given that only $55 \%$ of Serbian citizens support EU accession. ${ }^{50}$

\section{Notes}

1 This project has received funding from the European Union's Horizon 2020 research and innovation programme under grant agreement No 822682. It reflects only the author's view and the Agency is not responsible for any use that may be made of the information it contains.

2 In 2018, $60.5 \%$ of imports and $70.5 \%$ of exports were to/from EU member states. More can be found in the report of the European Commission, DirectorateGeneral for Trade, https://webgate.ec.europa.eu/isdb_results/factsheets/country/ details_serbia_en.pdf accessed 10 June 2020.

3 Marko Stojić, 'The changing nature of Serbian political parties' attitudes towards Serbian EU membership', (2011), 122, Sussex European Institute Working Paper, 4.

4 Balkan Insight, 'EU: Serbia Does Not Have to Recognize Kosovo', 2012, https:// balkaninsight.com/2012/09/05/eu-does-not-request-serbia-to-recognize-kosovo accessed 12 July 2020.

5 Ibid., 17.

6 Ibid.

7 Sofia Vasilopoulou, Far right parties and Euroscepticism. Patterns of Opposition, (ECPR Press 2018), 138.

8 Populist rebellion against modernity in 21st-century Eastern Europe (Poprebel) D4.1 Report: political populism from the fringe to the mainstream - a conceptual framework for WP4 (2020) 9.

9 Ibid.

10 Spyros Economides, 'From Fatigue to Resistance: EU Enlargement and the Western Balkans', (2020), Dahrendorf Forum Working Paper, 17.

11 Ibid., 8.

12 Hans-Jorg Trenz and Pieter de Wilde, 'Euro-scepticism: Mapping a new research field for RECON', (2008) RECON working papers, 1.

13 Aleks Szczerbiak and Paul Taggart, 'Theorising Party-Based Euroscepticism: Problems of Definition, Measurement, and Causality', in Szczerbiak and Taggart (eds), Opposing Europe? The Comparative Party Politics of Euroscepticism, vol 2, (Oxford University Press 2008) 2.

14 Ibid. 
15 Ibid.

16 Ibid.

17 Sofia Vasilopoulou, Far Right Parties and Euroscepticism. Patterns of Opposition, (ECPR Press 2018), 43.

18 Daphne Halikiopoulou, Kyriaki Nanou and Sofia Vasilopoulou 'The paradox of nationalism: The common denominator of radical right and radical left Euroscepticism', (2012), 51, European Journal of Political Research, 504.

19 Marko Stojić, 'The changing nature of Serbian political parties' attitudes towards Serbian EU membership', (2011), 122, Sussex European Institute Working Paper, 4.

20 Pokret Socijalista, https://pokretsocijalista.rs/ accessed 14 July 2020.

21 The Serbian Progressive Party (SNS) that is leading the coalition declares itself as pro-European while the Movement of Socialists (PS) and the Serbian People's Party are Eurosceptic.

22 Igor Bandović and Marko Vujačić, 'The European Question in Serbia's Party Politics', in Corina Stratulat (ed), EU Integration and Party Politics in the Balkans, (ECP 2014), 54, 47-67.

23 Ibid.

24 Slobodan Antonić, 'Euroscepticism in Serbia', (2012), 5, Serbian Political Thought, 56.

25 Bandović and Vujačić, (n 22), 56.

26 Antonić, (n 24), 57.

27 Srpska Narodna Partija, https://srpskanarodnapartija.rs/en/ accessed15 July 2020.

28 ECR Party, https://ecrparty.eu/ accessed 15 July 2020.

29 Andrew MacDowall, 5 Takeaways from the Serbian Election, (Politico 2016) from www.politico.eu/article/5-takeaways-analysis-from-serbian-election-aleksandarvucic/ accessed 15 July 2020.

30 Milica Stojanović, Right-wing Serbian Party Launches Anti-Immigration Campaign, (Balkan Insight 2020), https://balkaninsight.com/2020/02/18/rightwing-serbian-party-launches-anti-immigration-campaign/ accessed 15 July 2020.

31 The SPS is a party with the longest tradition in Serbia since the 1990s; it was in power from 1990 to 2020 except for a short period after the democratic changes in the early 2000s (2001-2003). Nataša Jovanović Ajzenhamer and Haris Dajč 'The Serbian Socialist Party attitudes towards EU through the lens of party programmes: between pragmatism and patriotism', (2019), 63, Politeja, VI, 65-79.

32 Momir Trudić, Politika po principu sve je dozvoljeno, Vreme, www.vreme.com/ cms/view.php?id=1147358 accessed 7 July 2020.

33 Ivica Petrović, Zašto su raspisani izbori u Srbiji? DW, www.dw.com/bs/ za\%C5\%A1 to-su-raspisani-izbori-u-srbiji/a-18986231 accessed 7 July 2020.

34 Programme of the Serbian People's Party, Belgrade 2014, 4-5, (Program Srpske narodne partija).

35 It should be noted that access to the party manifestos of Serbian political parties is a challenge. Not all parties issue new manifestos before the elections, some only have a short list of goals published on their webpages.

36 Mikołaj Cześnik, 'Zawartość programów wyborczych polskich partii politycznych zastosowanie metody MRG do ilościowej analizy treści', in Inka Słodkowska and Magdalena Dołbakowska (eds), Wybory 2007. Partie $i$ ich programy, (ISP PAN Warszawa 2011), 12.

37 Programme of the political party Movement of Socialists fighting left, Belgrade 2008, 20, (Program politicke partije Pokret Socijalista borbena levica). 
38 http://ndps.rs/programska-deklaracija/ accessed 6 July 2020.

39 https://dostajebilo.rs/blog/2016/01/15/pravi-odnos-prema-evropskoj-uniji/ accessed 6 July 2020.

40 Programme of the DSS, www.dss.rs/srp/o-nama/dss-izbliza/program-stranke/ accessed 4 July 2020.

41 Ibid.

42 https://dveri.rs/zasto-dveri/program/van-eu-savez-sa-rusijom/accessed 4 July 2020.

43 Vojislav Šešelj was convicted of war crimes by the International Criminal Tribunal for former Yugoslavia (ICTY), where he spent 11 years and 9 months until late 2014 when he was permitted to temporarily return to Serbia to undergo cancer treatment.

44 Programme of the Serbian Radical Party, Hrtkovci 2019, 29-30, (Program Srpske radikalne stranke).

45 Ibid., 30, (Program Srpske radikalne stranke).

46 Programme of the Serbian People's Party, Belgrade 2014, 4-5, (Program Srpske narodne partija).

47 Ibid.

48 Marko Stojić, 'The changing nature of Serbian political parties' attitudes towards Serbian EU membership', (2011), 122, Sussex European Institute Working Paper, 36.

49 Natasza Styczyńska, 'Eurosceptic Parties in the Central and Eastern European Countries: A Comparative Case Study of Poland, Hungary and Bulgaria', in Benjamin Leruth, Nicholas Startin, Simon Usherwood (eds), The Routledge Handbook of Euroscepticism, (Routledge 2018), 139-154.

50 Ministry of European Integration, www.mei.gov.rs/eng/news/848/193/463/details/ j-joksimovic-55-of-serbian-citizens-support-eu-integration/ accessed 15 July 2020. 


\title{
12 Main varieties of Russian nationalism in the post-Soviet period and their relationship to European heritage and contemporariness
}

\author{
Joachim Diec
}

\section{Introduction}

The main task of this chapter is to draw a conceptual outline of the major trends in Russian nationalism after the collapse of the USSR in the context of its attitude to the European, or more broadly, Western question. To create such a typology, it is necessary to establish an insight into the diversity of those Russian nationalistic doctrines which functioned in that period with their main ideological positions by estimating the extent to which they are ingrained in the Russian tradition and investigating the type of impact on Russia's political and social life they can make in the next decades. This can be helpful in prognostic efforts which refer to the possible scenarios of the ideological development of contemporary Russian society, both in the internal and international perspective.

\section{Theoretical and methodological remarks}

As the main goal of our efforts is to review and structure the broad phenomenon of contemporary Russian nationalism, the theoretical basis of this study does not seem obvious. We observe the presence of different approaches in both Russian nationalist thought and political activities. Thus, the approach to this issue must necessarily be based on the inductive generalisation of the positions learned, regardless of the pre-existence of some primary assumptions and the hypotheses that existed in the researcher's tool kit.

However, there are certain key factors that facilitate some approaches to the detriment of others. There is, for example, a certain indisputable factor which is even reflected in the Russian language: the distinction between Russians as citizens (россияне) versus ethnic Russians (русские). Contemporary Russia is neither an entirely universal state (this was not even the case with the Soviet Union, despite its aspirations to being a defender of nations) nor a strictly national state dominated by one ethnic or cultural paradigm which was created for its support. What can be assumed at the outset of this study is the stronger position of primordialism in those cases where ethnicity has become the essence of nationalist doctrine. Alternatively, the state-oriented

DOI: $10.4324 / 9781003226123-15$ 
nationalistic circles would naturally precipitate instrumentalist interpretations of the Russian nation and its destiny in the international perspective.

Another theoretical hypothesis centres around the assumption that modernist approaches may not be as productive as they were in the context of many Western nations. We have to remember that Russian nationalists experienced the trauma of an imposed form of Marxism, which perceived any kind of nationalism as a useful element in the ideological superstructure of the capitalist society. That is why a post-Marxist and post-internationalist environment is naturally inclined to reject the idea of nationalism as an artificially constructed idea, one whose only function is to exploit the working class. In other words, the present study, being rooted in the inductive procedure, is directed toward a classification of approaches rather than toward the imposition of any single method.

\section{Recent analyses}

There are many important studies on Russian nationalism that have appeared in research efforts concerning Russian political thought. Some touch upon the issues of its earlier forms, the imperial period in particular. The more 'classical' forms, such as Slavophilism or Pan-Slavism, have been described in Walicki's monograph, ${ }^{1}$ whereas the phenomena of the period of decline and later forms of the trend were characterised by Laqueur. ${ }^{2}$ The very interesting problem of Russian nationalism in the USSR was discussed by Barghoorn in $1956^{3}$ and by Yitzak Brudny in $2000 .^{4}$

As far as the newest stages of the phenomenon in question are concerned, there are some valuable publications with such books as John B. Dunlop's Faces of Contemporary Russian Nationalism, ${ }^{5}$ the quite useful collection The New Russian Nationalism: Imperialism, Ethnicity and Authoritarianism 2000-15, edited by Pal Kolstø and Helge Blakkisrud, ${ }^{6}$ and Marlène Laruelle's brilliant monograph: Russian Nationalism: Imaginaries, Doctrines, and Political Battlefields of $2018^{7}$ (Laruelle offers a longer list of publications concerning Russian nationalism, and remains perhaps the most prolific expert in this area).

\section{The burden of tradition: a classification according to old standards?}

Russian nationalism has a long tradition, so there is a temptation to use either the divisions of its older forms or the general classifications of nationalism which are rooted in the basic models of understanding the concept of nation. In contemporary studies, Russian nationalism is traditionally classified into two categories: the ethnic and the statist. While promoting this kind of approach, Pål Kolstø refers to the two-axis scheme suggested by Sven Gunnar Simonsen, where one of the axes allows the drawing of a continuum from a pure orientation on the empire to an orientation on the 'core', and the other leads from a primarily statist orientation toward a purely ethnic one. The 
statists' positions stretch from Russian or Soviet imperialism to solidarity with the Russian Federation, whereas primarily ethnic nationalists represent either the supremacist position or, in the opposite extreme case, ethnic 'core' nationalism. ${ }^{8}$

This well-known model for portraying the complexity of Russian nationalism is useful and has been applied in several studies. However, what kind of device should be applied if the nationalist claims that the 'core' is imperial as such? If we return to the old Russian ideas conceived by such thinkers as Fyodor Dostoevsky or Fyodor Tyutchev, where the Russian soul is entirely universal and embraces the whole world and where Russia's destiny is to create the ultimate empire according to the principle of translatio imperii, we realise that no real ethnic or national core is designated apart from the providential idea of universalism and expansion under a religious banner. That is why a new look at understanding the trends in Russian nationalism would probably be more advisable than the traditional structure of axes previously mentioned.

The original assumption of this study is that nationalism (in the same way as the other political doctrines) never appears without a purpose. It is hard to find cases in the world's history of nationalism where nationalistic ideas were not a reaction to a real or imaginary threat which was posed by strangers or by an internally destructive factor. Russia has never been an exception, neither in the classical and Soviet past nor in the period of the Russian Federation. Russian nationalism is a phenomenon with a long tradition. During the reign of Nicholas I, 'Slavophilism' appeared as a reaction to the intellectual efforts of the Westerners, who preached Russia's inferiority in comparison with European cultural and political traditions. In the second half of the 19th century, during the time of great reforms, Pan-Slavism was supposed to be a response to Turkish and Western European dominance in the Black Sea region and the Balkans. Organisations that were usually classified as the Black Hundred formations fought against constitutionalists, liberal movements and socialist organisations; they were furious about the Jewish presence in the Russian economy and the press, as well as about the ambitions of Polish activists to regain independence. A study of nationalistic doctrines and movements cannot ignore the starting points of the processes, nor the irritating (or even threatening) phenomena which were woven into the overall situation underlying the emergence of various forms of nationalism. An influx of immigrants gives rise to an orientation in political thought which is different from the loss of independence, just as foreign religious or political hegemony does not cause the same phenomena as the confrontation of attractive ideologies which are foreign to the native culture.

After the collapse of the USSR, the political, economic, and social situation of the Russian people made them confront new challenges. Some old dilemmas remained, but there are many new factors that had to be taken into account while defining the perceived interests of contemporary Russia and the destiny of the Russian nation. The global geopolitical situation underwent 
a drastic transformation after 1990 and the changes predominantly impacted Moscow, which was reduced to the position of a regional power with rusting nuclear weapons in its pockets. Russia then experienced an economic disaster in the 1990s, was humiliated in the First Chechen War, and, after gaining a more convincing form of political and economic stability at the beginning of the third millennium, was forced to determine a relevant attitude to its North Caucasian Muslim citizens and immigration from Central Asia - a lost part of the vanished empire.

For these reasons, it may be inadequate to simply apply the well-rooted schemes and oppositions of Slavophil vs Westerner, monarchist vs republican, ethnic vs statist, etc. in the specific situation of the first three decades which followed the collapse of the Berlin Wall. A review of the recent trends in Russian nationalism ought to reflect the changing reality of the society in question, as with all historical nationalist phenomena in any country.

\section{The beginnings: a step towards freedom from communism and internationalist pressure}

A superficial glance at the oldest genuinely nationalistic organisation of the post-communist times, the National-Patriotic Front 'Pamyat' (Национальнопатриотический фронт «Память», НПФ «Память»), might surprise the observer since its roots can be traced back to the late 1970s when a traditionalistic and patriotic circle called Vityaz was created under the auspices of the Soviet Society for the Protection of Historical and Cultural Monuments (Общество охраны памятников истории и культуры). ${ }^{9}$ The most prominent Vityaz activists tried to defend Russian culture against the destructive trends of communist modernity. The most famous of them, Ilya Glazunov, created the patriotic club Rodina (Homeland) in the early 1960s. Later, in the 1970s, he successfully opposed the Master Plan for the reconstruction of Moscow, which threatened the historical part of the city with almost complete destruction. ${ }^{10}$ Positions like this were rare because of the pressure the regime exerted on intellectual circles. However, they always made their presence felt (at least after the Stalinist period) and were represented predominantly in art and literature with such famous names as Vladimir Soloukhin, a prominent traditionalist among Russian writers, who preached the necessity to preserve the treasury of Russian culture despite modernist pressure and wept over the lost architectural monuments of Moscow.

In 1980, the club became an organisation and was given wings by Gorbachev's perestroika. From 1988 until his death in 2003, the organisation's leader was Dmitry Vasilyev, a little-known actor but a talented organiser and ideologist who supported Gorbachev's reforms against communist radicals in the same way that he offered his support for Yeltsin. The reason was clear: the further society shifted from communism and the closer it came to traditional, non-Soviet Russia, the better for the Russian people. Soon, many organisations, which included 'Pamyat' in their names, appeared in several 
places throughout Russia, their leaders quarrelling with each other about ideological matters.

The general orientation of these groups was ostentatiously patriotic and linked to various versions of the Judeo-Masonic conspiracy theory. The slogan of Vasilyev's group (the 'true' National-Patriotic Front 'Pamyat') was 'God, Tsar, Nation', which generally reflected its preoccupation with reconstructing old Russia as defined by its religion, monarchy and national spirit. Vasilyev openly declares: 'I am a fascist, a Russian fascist, there is nothing wrong with that. If you want, I'm a monarchist, the union of the nation in the name of the monarchy is wonderful. But not a Nazi, not a National Socialist, this is the sphere of communist ideology.'11

This kind of Russian nationalism was a child of its time. Pamyat (which in Russian means memory) grew out of the experience of totalitarian communism, which annihilated everything associated with traditional Russia. It destroyed the former political system, which had existed for centuries, and had religious legitimacy. It also brutally persecuted Orthodoxy, the national religion, and replaced old customs with socialist rites. The trauma of an oppressive and anti-Russian system gave birth to various reactions and the kind of nationalism that looked back to the Black Hundred was one of many.

Pamyat was by no means the only doctrine of its kind. The organisation should be categorised somewhere between 'soft' intellectuals and various groups of radicals. Personalities such as the Noble Prize winner in Literature Aleksandr Isaevich Solzhenitsyn (1918-2008) or Igor Rostislavovich Shafarevich (1923-2017), a top-class mathematician, represented the trend of 'Memory', both in the last decades of communism in Russia and after 1990. Solzhenitsyn, in some of his essays, especially in Rebuilding Russia (Как нам обустроить Россию), ${ }^{12}$ Russia under Avalanche (Россия в обвале) ${ }^{13}$ and Two Hundred Years Together (Двести лет вместе), ${ }^{14}$ expressed his desire to reconstruct the spirit of the Russian nation and to rebuild a genuinely Russian state. After his categorical rejection of Marxist ideology, which was expressed in the famous Letter to the leaders of the Soviet Union (Письмо вождям Советского Союза), ${ }^{15}$ Solzhenitsyn propagated, above all, a return to the roots of Russianness, with its traditional folk culture and attachment to Orthodox Christianity. He did not fuel great power ambitions, as he believed that the Russians should strive for self-restraint, admit their sins, and build Russia only within its ethnic borders. ${ }^{16}$ He suggested, however, that the Ukrainians and Belarusians were an inseparable part of the Russian ethnic element. When the walls of discord arose between Russia and Ukraine in 2004, he said in an interview that leaving 25 million ethnic Russians outside the state was openly unjust. In his opinion, with regard to modern Ukraine, a significant part of the country's territory (mainly the so-called Novorossiya New Russia - or Crimea) had never constituted part of Ukraine as such before the advent of communism. ${ }^{17}$ In Solzhenitsyn's writings, the Soviet state, contrary to some Western accusations, did not promote Russification in the ethnically non-Russian provinces. Rather, it systematically destroyed 
the Russian national element and its culture with the rural substrate as the main component.

In general, as Solzhenitsyn believed, the West had made a faulty assessment of the situation in the communist East. This was not, however, a result of an erratic methodology but of a spoiling historical experience. In his famous Harvard address the writer said that

a short a time ago, relatively, the small, new European world was easily seizing colonies everywhere, not only without anticipating any real resistance, but also usually despising any possible values in the conquered people's approach to life. On the face of it, it was an overwhelming success. There were no geographic frontiers to it. Western society expanded in a triumph of human independence and power. And all of a sudden in the 20 th century came the discovery of its fragility and friability. ${ }^{18}$

Solzhenitsyn accused Western societies, especially the ruling elites, of cowardice. Having been granted well-being to an extent their fathers and grandfathers could not have even dreamed about, the people of the West were not ready to risk their precious lives when another nation's security was under threat. Western societies are obsessed with law, which leads them to manipulate it and abandon any moral imperatives that go beyond the letter of the law: 'Nobody will mention that one could still not be entirely right, and urge self-restraint, a willingness to renounce such legal rights, sacrifice and selfless risk' ${ }^{19}$

In his writings, Solzhenitsyn also makes his reader aware of the Jewish question in Russia. However, in his famous essay about this issue, he did not criticise Jewish circles in general. In contrast, he claimed that both imperial Russia and the Soviet Union did not offer proper conditions for making Russian Jews equal citizens. In this way, he explained the overrepresentation of Jews in Bolshevik organs of power. ${ }^{20}$

Igor Shafarevich perceived this problem in a slightly sharper way. In his frequently criticised book The Three Thousand Years' Riddle (Трехтысячелетняя загадка) ${ }^{21}$ and several other texts, such as the famous Russophobia (Русофобия), ${ }^{22}$ he suggested that it is unfair to state that the Russian Revolution and communism were originally created by Jews. However, because of their insularity and traditional messianism (a belief which was later deprived of its religious sense), they were naturally inclined to approve of the Marxist ideology as a transformed instruction on how to save the world. In other words, the Jews were not the ones who initiated revolutionary socialism in Russia, but the ultimate triumph of the revolution would not have been possible without the zeal presented by revolutionaries of Jewish descent. ${ }^{23}$ Shafarevich's main preoccupation, however, was not the Jewish question but rather the problem of Russia's internal enemies. His Russophobia is a study of various forms of dislikes toward his country (although he is aware that this kind of resentment is by no means reserved for Russia). As he claimed, 
there are several thinkers and activists living inside Russia or the West who have discredited the Russian past, its destiny, traditional religiosity and its imaginary 'slavish soul', and who, last but not least, reject Russia's positive contribution to the world's history. ${ }^{24}$ Shafarevich's considerations provide additional evidence for the argument that the Russian nationalism of recent decades is rather reactive. It began as a criticism of the destructive power of communism and continued as a criticism against Russophobia.

The presence of Russophobia in Europe (and the West in general) is perhaps at a similar level as it is amongst internal dissidents, yet how to explain its enduring popularity, a factor which became even more obvious after the Cold War? Shafarevich provides a more analytical and historical critique of the West than Solzhenitsyn. The mathematician explains its mobilisation with Pico della Mirandola's diagnosis (given in his De hominis dignitate), according to which the new man will gain power over things and people, being able to communicate with all levels of the universe. In general, the will and power over nature and man became the imperative of homo occidentalis. This was the driving force behind Francis Bacon's experimental method and desire to uncover the secrets of nature, which prompted Newton's discoveries and the achievements of the London Royal Society. In terms of social instincts, the West was driven by the same trigger as the Roman Empire: the Augustinian libido dominandi. This feature became a sufficient condition and breeding ground for the Roman desire for profit. It is the same spirit that permeates Schopenhauer and Nietzsche's philosophies; and the modus vivendi undisguised by Marx was, after all, the struggle for an ultimate solution. ${ }^{25}$

Shafarevich sees the most fundamental properties of European civilisation in the social consequences of capitalism, which itself is responsible for social atomisation. Social changes in the West were subordinated to the needs of capitalism. In practice, this led to the concentration of the population in cities and industrial centres and the loss of human resources in rural areas. It was actually a violation of the natural distribution of the population in their countries, but also an axiological transformation. The power of Ancient Greece, even the metropolitan city of Athens, was created primarily by the culture and political organisation of farmers coming to the cities. For centuries, the main pillar of European societies was the peasantry until that disastrous breakthrough, which meant the expulsion of people from their natural environment and exposing them to the temptations of the city. The change was particularly dramatic in England, where peasants were violently forced to leave the countryside and create an urban proletariat. In subsequent centuries, the tissue of the agricultural and artisanal life of the colonial countries was annihilated, generating millions of victims of the system. The silent majority was subordinated to the power of the city and industrial regions. ${ }^{26}$

It is Russia that became a special experiment in this process. It was a country where, on the eve of the revolution, peasants made up four-fifths of the population. The peasantry remained in a state of constant dissatisfaction over low incomes. The February Revolution of 1917 brought the 
Constitutional Democrats and Socialist Revolutionaries to power, i.e. parties seeking to solve this problem by dividing up the land owned by the aristocracy and plantation owners. After the October Revolution, the Bolsheviks tried to implement this postulate through the Land Decree, but all the data indicate that the expansion of farms was symbolic. The following activities were in fact directed towards the 'liberation of peasants from the rural idiocy'. ${ }^{27}$

These premises led the mathematician to the conclusion that there were deep parallels between the civilisation of the liberal West and the Stalinist version of communism. Both are based on the ideology of progress understood in materialistic terms. Both chose the technocratic model of development. Both the West and Sovietism became urban civilisations, rejecting with contempt not agriculture per se, but rather the peasant mentality. Both are therefore based on dangerous utopias that lead to dehumanisation and, consequently, to self-destruction. In both cases we can observe a rejection of the Aristotelian principle of the limitations of all organic bodies. In classical metaphysics, organicity logically entails limitation, while the principle of technical civilisation is development without limits in any aspect. In other words, capitalism, which is a creation of the European West, and technocratic Communism are in fact two roads to the same precipice. ${ }^{28}$

\section{The trauma of the fallen empire and 'imperial nationalists'}

The internal crisis and final collapse of the USSR led to two different reactions: some felt empowered to speak on behalf of the Orthodox nation, oppressed by the reds, but there were also those for whom the fall of the empire was the greatest problem. This kind of discomfort resulted both from the injury which was inflicted on megalomania, as well as from the awareness that many ethnic Russians, who belonged to a once- dominant imperial nation, found themselves outside the borders of the modern Russian state. What seems quite curious is that a non-communist (but statist) party appeared two years before the end of the USSR: the Liberal-Democratic Party of the Soviet Union (Либерально-демократическая партия Советского Союза, ЛДПСС), which was officially registered on 12 April 1991. Although it was established by Vladimir Bogachev, very soon another active politician Vladimir Volfovch Zhirinovsky (Eidelstein) - took the chairman's position for more than three decades. This happened even though Bogachev, whose ideological roots were in the Democratic Union, tried to remove Zhirinovsky from the party in 1990 because of his real or alleged cooperation with the KGB.

After the collapse of the USSR, the party changed its name to the LiberalDemocratic Party of Russia (Либерално-Демократическая Партия России, LDPR) and assumed a controversial ideological shape. On the one hand, it is liberal and supports the free-market and freedom of speech. It is absolutely democratic and is in favour of the people expressing their power in free elections. The LDPR rejects communism and Marxism and supports the idea of the rule of law. The problem lies in the fact that Zhirinovsky and his 
people were unnaturally nation-oriented and never accepted the collapse (or partitioning) of the state. They proclaimed the need to reconstruct the empire while avoiding its previous red coating. In their minds, the Russian Empire (as well as the Soviet Union) did not act for the sake of the Russian nation. As their programme manifesto states, the Russians never had their own territory in Russia, as was the case with the minorities. That is why it is now impossible to allow the right to national self-determination within the limits of Russia or any other official language than Russian. Zhirinovsky would like to limit the West's influence and genuinely promote Russian culture. What seems more dangerous is his belief that the Russians were the most divided people after 1991. To reunite them, it is necessary to peacefully return the territories which were lost due to the Belovezha Accords in 1991. ${ }^{29}$ The LDPR is supposed to be a 'licensed opposition', as it held the position of the third power in the State Duma, the lower house of Russia's National Assembly, for many decades.

Zhirinovsky's view of Europe is generally negative. Neither in the party's programme nor in less official publications is any possible friendly relationship mentioned. On the contrary, the necessity of separation is instead emphasised. Russia should pursue the route of autarchy rather than imitate anyone else, especially Western civilisation. After all, what are the so-called Western values? They are mainly individualism, selfishness, a sense of superiority, a hard, inhuman struggle based on social Darwinism, contempt for weakness and poverty, colonial expansionism and plunder. It is the Weberian Protestant ethic that ultimately formed animalist capitalism and theoretically justified racism, Nazism and fascism. This 'cultural code of the West' must certainly not be instilled in the youth. Ukraine is testimony to this experiment, where its deplorable results are all too visible. ${ }^{30}$

Similar but less aggressive strains are characteristic of the Congress of Russian Communities (Конгресс русских общин), which existed between 1993 and 2003 before being refounded in 2011, as well as the Rodina (Homeland) Party, both of which were launched by Dmitry Rogozin. However, some other moderate nationalists, such as Sergey Glazyev or Sergey Baburin, played a considerable role in the actions of the Congress and Rodina, which after its creation in 2003 ceased to exist in 2006 but was later reborn in 2012. The Congress is an organisation that unites Russian minorities predominantly in the former Soviet republics, whereas Rodina is considered to be an internal actor. At the beginning of the 2020s, neither the Congress nor Rodina could be regarded as the leading nationalist forces in Russia.

The attitude of Dmitry Rogozin himself and the environment of the Congress of Russian Communities-Rodina towards Europe seems much less critical than it is in the case of the LDPR. Understandably, activists from this circle resent the apparent fact that new EU states do not respect the rights of the Russian minority. Generally, however, and perhaps surprisingly, Europe is understood by Rogozin as a common home, and also for Russians. Europe is a temple built from the sacred stones of the past, yet one which contemporary Western civilisation is abandoning. Rogozin is critical of European tolerance, 
which takes the form of cold isolation, behind which hides increasing xenophobia. Europeans pretend that nothing bad is happening in regions they consider 'foreign' because it is convenient for them. In reality, however, a pronounced shift to the radical right can be expected in Europe, largely triggered by the sense of being threatened by immigration. Against the background of what is likely to come, Russian nationalist groups will prove to be innocent lambs. Rogozin himself, whose rhetoric has weakened significantly after years as the ambassador of the Russian Federation to NATO, considers himself a right-wing politician, but a 'Russian Gaullist' rather than a National Front xenophobe. ${ }^{31}$

A similar (i.e. not very impressive) degree of popularity is characteristic of another imperialist nationalist party, Great Russia (Великая Россия). Тhe official founder of the party was Dmitry Rogozin, but the actual leader of this formation was Andrei Savelyev, who was the author of many high-profile publications. The party's programme envisages Russia only for real Russians, i.e. those people who were brought up in the circle of Russian culture and professing Russian values. At the same time, Great Russia propagates the idea of a unitary state that does not allow any foreign element to influence it. ${ }^{32}$ Great Russia is one of the groups that consider a specific conservativenational text - the Russian Doctrine - to be an important part of their view of Russia and the world. It was created in 2005 by a broad group, with Andrei Kobiakov, Vitaly Averyanov and Vladimir Kucherenko as the most active experts. The authors do not treat the document as a party programme but rather a set of guidelines and beliefs that can be used by various groups and institutions. The starting point of the document is the remark that today's Russia is in deep crisis and the scenarios of a total collapse or stagnation are by all means possible. One of the basic positive postulates of the initiative is to develop a national idea based on tradition. It is therefore a typical example of conservative nationalism. As the authors believe, the ideas of 'nationalism' and a 'national state' in recent centuries have often worked as subversive slogans, and still function in this capacity (such as the so-called colour revolutions). Nationalism is considered to be an occasion for the isolation and decomposition of the existing state orders and old civilisations. For historical Russia, such nationalism is not characteristic. Russian nationalism is supposed to be of a completely different type: it is not the 'nation' in itself which is valuable, but the national tradition in it; the nation, although changing and developing in time, does not change itself. In the history of Russia, the nation state does not appear as a den for a separate tribe, but rather as an orphanage, which adopts tribes who then become part of the great Russian nation. ${ }^{33}$ This approach is one of many examples where Russia is treated not as an ethnic phenomenon, but rather as a separate civilisation.

The founders of the Russian Doctrine regard the European influence in Russia as quite problematic, tending to resort to Koliev, who in his book Nation and State claims that there are two approaches that assess the relationship between the nation and the state in different ways. For Western scholars, 
a nation is historical and to a large extent constructed by the authorities, while for Eastern ones, artificiality may refer to a state which may turn out to be chimeric and anti-national. The use of Western approaches and an attempt to forget the prehistory of state formation have a harmful effect on the spiritual health of Eastern European nations. They are beginning to be credited with the model of a Western-style state, which is one of division and assimilation. The peoples characterised by various social and sub-cultural layers find themselves in conditions which supposedly split them up into small units in order to form national states of the Western type. Meanwhile, this process can only be stopped by the national core, which has gathered other peoples around itself and formed a national hierarchy within an empire.

Compared to European modernity, postmodernists have advanced even further in the decomposition of the idea of an 'organic nation', they generally consider the nation a 'cultural fiction' or an 'ideological mirage'. The roots of this understanding lie in a deliberate narrowing of perspective: if we propose that we consider a person as a unity of heredity, upbringing and situation, then modernists, willingly or not, ignore heredity, and postmodernists narrow the perception of social phenomena to 'situation', 'socialisation', rejecting not only the 'genetic' element of personality, but also their upbringing. Postmodernists, therefore, reproduce the scheme of an atomised society of scattered individuals alienated from each other, who appear from nowhere as adults and complete 'persons' in themselves. ${ }^{34}$

There is an obvious controversy as to whether another fundamental phenomenon in Russia's political and intellectual life - the neo-Eurasianist movement headed by Aleksandr Dugin and represented previously by such thinkers as Aleksandr Panarin and Geydar Dzhemal and now by Valery Korovin - can be considered a specific case of nationalism. The Eurasianists reject the ideological and geopolitical dominance of the Western, 'Mondialist' and 'Talassocratic' proposal with its democracy, free-market, and the apology of liberalism which is focused on the individual. What they propose instead is the ideological power of the traditionalistic Eurasian continent, which is a defender of religion, communitarianism and faithfulness to traditional commitments. ${ }^{35}$ This radical anti-Western, anti-liberal, and anti-democratic doctrine could be perceived as a kind of nationalism only if one accepts the existence of an imaginary 'Eurasian nation'. Otherwise, it should rather be treated as a specific example of quasi-conservative totalitarianism.

The Eurasian option can be treated as predominant in the initiative of the Izborsky Club, which is an association of nationalistic, conservative, antiliberal and anti-American thinkers and activists that was founded in 2012. The chairman of the club, Aleksandr A. Prokhanov, is a well-known writer who represents the most characteristic and a quite paradoxical ideological trait of the group: the tendency to reconcile two incompatible traditions - the traditionalism of Orthodox, monarchist 'white' Russia and the heroism of the Soviet (mainly Stalinist) period which was reflected in the victory over Nazism. The leaders of the club describe their orientation as 'patriotic' and would like 
to contribute to the formation of a new agenda in the Russian media - the conquest of information niches which objectively arise in connection with the 'ideological and moral decline' of the liberal community. ${ }^{36}$

The Izborsky Club issues its monthly journal Izborskiy Klub (Russkie strategii) with surprising regularity, consistently maintaining its aggressive anti-Western tone on the one hand and a dreamer's approach toward imaginary prospects on the other, which is also reflected in Prokhanov's 2019 book In Search of the Russian Dream (B поисках русской мечтыл). ${ }^{37}$ Laruelle claims that today's studies on Russian nationalism concentrate more on classifications but 'ignore the issue of institutional location'. Continuing this position, she finally concludes that the patronage of the Kremlin over the club seems unlikely and that support for the group should rather be traced to influential rightist politicians, such as Rogozin and Sergey Glazyev. Moreover, according to her, allies should be sought within the military and militaryindustrial complex and the anti-liberal camp, which tries to influence the main centre of power. ${ }^{38}$ This remark seems reasonable, as a similar case of support from the military circles characterised the publication initiatives of Dugin and the early neo-Eurasianism of the 1990s. In other words, the 'relative' impact of the imperialist, 'geopolitical' nationalists ought to be perceived from the perspective of various influences surrounding the Kremlin, with a particular emphasis on the role of the 'force camp' and media radicals in the style of Mikhail Leontyev, who oppose the supporters of free-market commitments and cooperation with the West.

The essence of the neo-Eurasianist anti-Westernism lies in the belief in the so-called mondialism, the Atlantic, predominantly Anglo-Saxon, doctrine, which is supposed to subordinate the rest of the world to the philosophy of extreme individualism, where any obligations to one's community are dissolved in the waters of the geopolitical sea. However, for Dugin, Europe is not doomed to sink beneath the waves of Atlanticism: there is still another option - the 'continental' German-oriented vision of a unity faithful to its traditional communitarian authoritarianism. Central Europe, contrary to Mackinder's expectations, should follow the vision of Naumann's Mitteleuropa, which found its best implication in the works of Karl Haushofer. What Dugin himself proposes is a European Empire, predominantly led by the German nation, a reliable partner of Eurasia, yet dominated by Russia. ${ }^{39}$

\section{The radical anti-communist response}

16 October 1990 is the birthdate of Russian National Unity (Русское национальное единство), a nationalist organisation which grew out of Pamyat and was established by Aleksandr Barkashov, its former member and Vasilyev's bodyguard. In his major programme manifesto, which was formulated in 1994 and entitled The ABC's of a Russian Nationalist, the author tried (from a nationalist point of view) to comprehend the current crisis in Russia and to outline possible ways to overcome it. He strongly contrasted the 
concepts of patriotism and nationalism. A patriot is a statesman, and the state has been working against the Russian nation (including not only the Great Russians but also the Ukrainians and Belarusians) since 1917. Therefore, the $A B C$ 's suggested breaking this anti-national state by a national social revolution, which was supposed to establish a 'national dictatorship'. The author does not hide his positive attitude toward Nazism. On the other hand, Barkashov associated the Bolshevik Revolution with the conspiracy of a transnational financial oligarchy, i.e. a controlling stake which belongs to Jewish financiers. The emissary of this specific red oligarchy in Russia was Leon Trotsky. Nevertheless, the USSR as a whole was not so unambiguously evaluated. By 1937, among the Bolsheviks of Slavic origin, a faction of 'National Communists' was formed, which then engaged in an internal party struggle with the Jewish 'internationalists'. However, in 1985, the latter evolved into 'democrats' whose invention of 'perestroika' led to the transformation of Russia into a 'semi-colonial third world country'. Therefore, the Russian nation is obliged to resist this influence, and the first stage of resistance is the transformation of a collection of people into a nation through the growth of national self-consciousness. The second is the creation of a unitary national state that is headed by an omnipotent National Council. ${ }^{40}$

In September 2000, the organisation split into factions after the secession of a group led by Oleg Kassin and Yuri Vasin. In subsequent years, further disintegration ensued but it must be remembered that, at least until 1995, Russian National Unity (RNU) nearly monopolised the radically nationalistic camp by developing 58 regional branches inside the Russian Federation and four branches abroad. These were located in Belarus, Ukraine, Latvia and Estonia. $^{41}$

RNU and its daughter organisations, such as Russian Revival (Russkoe vozrozhdenie), are only the most radical incarnations of the same stripe as Pamyat or the considerations of conservative-nationalistic intellectual prophets. They all reacted to the destruction of the Russian nation, which they felt had been caused by communism and the first years of the Russian Federation. Their leaders did not see Russians as being responsible for the revolution and the socio-economic catastrophe of the 1990s. Instead, they perceived the source of evil as existing in an alleged Jewish or Masonic conspiracy. Only in this sense did their ideology approach Nazism and finally succumb to the temptation of extreme racist anti-Semitism. However, just as with the origins of the Nazis, RNU's racism was only a rather late and random form of the pseudoscientific exploration of the political, social and economic disaster in the 21 st century. As Dunlop correctly stated, the strength of the RNU's neo-Nazi movement 'lies in the self-imposed weakness of the Russian state'. ${ }^{42}$

Particularly noteworthy is the fact that RNU, which is very critical of the contemporary Russian political elite and does not perceive the Russian Federation as a state that could satisfy the nation's interests, is also very reluctant to express any comments on Europe or the West in general. Contrary 
to the imperial nationalists or totalitarian neo-Eurasianists, the Russian National Unity sees the enemy not in the West but in the multinational corporate state, one which preys on the flesh of the Russian people, torn apart by a supranational parasitic oligarchy and foreign elements in the country.

However, if this is the case, we can realise that the Russian nationalism of the post-Soviet era reacted to at least two different phenomena: the social disaster of the nation and the 'inadequacy' of the state. As it is, the social collapse might have been caused by the inadequacy of the new Russian state: both aspects overlapped.

\section{The national socialists - a response to the pressure of 'racial strangers'}

Another option for ethnic nationalism in Russia is the national-socialist trend which was represented predominantly by the Slavic Union (Славянский Союз, Slavyansky Soyuz, SS), and which was established in September 1999 by Dmitry Demushkin, a legendary national-socialist leader. The Union's association with Nazism was quite obvious, especially if one considers the abbreviation (SS) which stands for the name of the organisation. Its ideology embraced such postulates as the creation of a superman, racial purity and the predominance of ethnic Russians in the state (without the extermination or displacement of other ethnic groups). Russia is generally treated as the victim of a foreign occupation..$^{43}$

After the Slavic Union was banned (27 April 2010), Demushkin and his companions created another organisation with the same Russian acronym (SS): The Slavic Power (Славянская Сила), and after the subsequent ban, his third national-socialist association - The Russians (Русские), which was also outlawed as extremist in 2015. It proclaimed its mission to be one of upholding the rights and interests of the Russian population, both within the country and abroad. The association advocated the creation of a Russian national state and government.

Demushkin, as a devout nationalist, however, is paradoxically far from European nationalists but not because of their axiological profile. He points to a ridiculous trait of the European far-right: their cooperation with the Russian authorities. In other words, the ideological line of the Slavic Union/ The Slavic Power/The Russians is relatively close to the RNU, and therefore extremely critical of the Kremlin, which is accused of neglecting the interests of the Russian nation and subordinating it to a multiracial Eurasian blend. That is why such European creations as National Rally or the Italian Lega are criticised in ethnic nationalist circles in Russia. ${ }^{44}$

The national-socialist line was continued by various organisations, some of which were definitely extremist, even resorting to radical Western symbols and names: the National Socialist Society (Национал-социалистическое общество), Schulz-88 (Шульц-88), the Skinhead group Lincoln-88 (Линкольн88 ), etc. Many of their members were involved in several legal procedures 
which led to their imprisonment. An interesting case of a racist Nazi organisation is the National People's Party (Народная национальная партия) which was headed by Aleksandr Ivanov-Sukharevsky, who proclaimed the ideology of 'Russism', wherein the fate of the white race, especially in Russia, is illustrated as a history of a genocide, which justifies the anti-Semitic tendencies among all Russians. ${ }^{45}$ In this way the Russian ethnic and racist radicals are becoming closer to Western Nazi or fascist ideology, one additionally strengthened by the use of analogical iconography.

\section{Pro-Western and democratic nationalists}

For many years, the National People's Party was inspired by the interesting personality of Aleksey Shiropaev, the author of a scandalous but very interesting book, The Prison of the Nation (Тюрьма народа). The author intentionally paraphrased the popular term 'the prison of nations' referring to tsarist Russia as a state oppressing many ethnic groups. This time, however, we receive a story about the Russian state as an entity directed against its own nation, thus making it the object of extermination. This tendency manifested itself in the medieval inclinations of some princes to accept foreign, nonAryan influences: Byzantine Christianity (which was derived from the religion of Jews), the habits of the nomadic Turkic peoples, and Mongolian despotism, which would later master the entire philosophy of the Russian state. As Shiropaev claims, the highly genocidal Bolshevism, created by the Jewish minority, as well as the contemporary Caucasian and Asian influences, are also highly destructive. ${ }^{46}$

Later, Shiropaev, with some other activists, created the NationalDemocratic Alliance (Национал-Демократический Альянс, NDA), which has nothing in common with any of the older traditions of Russian nationalism. The NDA does not continue the traditions of the Slavophils, Pochvenniks, Pan-Slavists or the Black Hundred organisations. It rejects the Soviet legacy and radically condemns all forms of Eurasianism. It offers a kind of 'tribal' nationalism, but the outcome of the NDA's position does not resemble any of the old ethnic doctrines. The Russian nationalist tradition most commonly opposed Russia and the Russian people to the West, who were normally associated with the greatest threats. The NDA, however, contrary to Russian nationalistic statists and Orthodox traditionalists, opts for the federalisation of the state, anti-communism, the rejection of the glorification of the Soviet victory over fascism, anti-clericalism, limiting immigration from the East and the South, establishing cooperation with NATO and the European Union, and, most importantly, it advocates for a real democratisation of the state, which would allow a free expression for the Russian people about how their social life and state policy should work. ${ }^{47}$

Russian National Democrats openly declare their devotion to European values. As Nikolai Markin, one of their activists, declared in 2016, 'a normal Russian nationalist is a European'. He also believes that sentiments among 
Russian nationalists are gradually shifting from imperialism towards the ethnic, pro-European sort of doctrine. What is necessary is a 'restart' of relations with Europe and the United States. To do this Russia needs to introduce a visa regime with Central Asia, and strengthen its existing policies towards China and North Korea. Russia has the most extensive border with the PRC, which in Markin's opinion is dangerous in all respects. Being unable to choose its neighbours, Russia should establish military and political cooperation with NATO member states to prevent Chinese expansion into the Russian Federation. ${ }^{48}$

Markin's optimism, however, has not been reflected in public opinion polls in Russia. According to the data review provided by the Yuri Levada Analytical Centre on 23 Mar 2021, the intensity of European identity among Russians has been significantly decreasing since 2008. Asked whether they considered Russia a European country, 52\% of respondents said 'yes' in Sep 2008, 37\% in Aug 2019 and only 29\% in 2021. The question 'Do you consider yourself a European' received a positive answer in 35\% of responses in Aug 2008, 33\% in Aug 2019 and 27\% in Feb 2021. The general tendency revealed by Levada's research is that the younger the generation, the less it considers itself to be European. ${ }^{49}$

\section{The 'cultural' nationalists}

Another trend of Russian nationalism adheres to a cultural definition of the doctrine. The early 1990s gave birth to a radical change in Russian policies, which manifested itself in such phenomena as wild capitalism, 'unfair' privatisation, oligarchism perceived as 'corrupted statism', lenience toward the Islamic element in the Northern Caucasus, and Russia's uncontrolled access to the rules of globalisation. None of these points were in any way familiar to Russian cultural heritage. This caused a reaction in the shape of the Russian Nationwide Union (Русский общенациональный союз, RONS), which later appeared in the media as Russia Will Be Freed Вy Our Forces (Россия Освободится Нашими Силами) with Igor V. Artemov at the helm. As they declared in their creed, the organisation does not accept the current political regime in the Russian Federation, as under it Russianness is being gradually destroyed and Orthodoxy is being perverted. What they propose instead is a nation-focused state based on Christian values, national control over natural resources, genuine democracy that should replace the corrupted regime which is supported by socially uncontrolled oppressive state formations, and, last but not least, a strict limit on immigration. ${ }^{50}$ In other words, RONS is trying to avoid criticism of Europe or the West in general, despite using some Slavophile patterns. The founders of the movement created its programme as the manifesto of a traditional Christian Democratic party.

This ideological line was supported by intellectual moderate nationalists of a new wave, whose explication can be found in the journal Voprosy nacionalizma (Вопросы национализма), which was for many years associated 
with its leading columnist, Konstantin Krylov, the founder of the unregistered National-Democratic Party (Национально-Демократическая партия), and was later directed by his widow, Nadezhda V. Shalimova.

\section{The religious challenge}

One of the most important aspects of Russia's social collapse was the radical eradication of religious life in the state. In the last years of the Russian Empire, Russia was (by all means) a religious country. Its multi-ethnic population practised their religions regularly in a very traditional, rather than modernist, way. The Orthodox Church, which was the state religion, enjoyed the position of real power. It had at least 87 million adherents, most of whom attended liturgical services weekly on Sundays, as well as on other red-letter days. However, the real situation was much worse than the official narrative of the throne and the clergy. In the 19th century, the process of gradual secularisation in nearly all social strata of the Empire progressed, and after 1900 even the highest hierarchs admitted that they were experiencing the beginning of the end. ${ }^{51}$ However, after the collapse of communism, the image of a lost religious paradise was idyllic and a tendency among nationalists to create a new form of the Orthodox state became noticeable.

This is the background of the phenomenon of Russian Orthodox nationalism as represented by such organisations as the Union of Orthodox Banner Bearers (Союз православных хоругвеносцев), which was formed in 1992 and is headed by Leonid Donatovich Simonovich-Nikshich. The organisation's main propaganda slogan was imported from the 19th century with Count Sergei Uvarov's educational doctrine of 'Orthodoxy, Autocracy, Nationhood' (Православіе Самодержавіе Народность). ${ }^{52}$ The major objectives of the Union are strengthening the Orthodox faith and the establishment of an absolute monarchy with solid ties between the throne and altar. As the visionaries of an Orthodox and ethnically Russian state, the Union's leaders disapprove of the Jewish influence, as well as of mass migration from the predominantly Muslim Northern Caucasus and Central Asia into the Russian interior. A similar but less radical position is held by the Union of Orthodox Citizens (Союз православных граждан) which was established in 1995 with the intention of protecting the interests of the Russian Orthodox Church and introducing the spiritual principles of Orthodoxy into all spheres of life. The organisation not only functions in Russia but also in Ukraine and Kazakhstan.

The zeal of both unions may seem unnecessary in a country where the number of Orthodox temples, monasteries and believers shows an upward trend. However, the reality, as it used to be in the imperial era, is far from clear. One could suppose that, after the collapse of the atheistic and destructive communist regime, a religious upper tide would flood Russian soil. In fact, according to the Pew Research Center, Russia in 2017 was $71 \%$ inhabited by Orthodox Christians, but only $6 \%$ of them attended 
church weekly. This is a modest percentage if one considers the fact that in Ukraine and Belarus the index reaches $12 \%$, and in the case of the Ukrainian Byzantine Catholics and Polish Roman Catholics it exceeded $40 \% .{ }^{53}$ Only after considering these facts can we understand why Russian Orthodox nationalists find it necessary to establish an autocratic and theocratic state: from the perspective of genuinely realised values, they feel like a minority in their own country.

The attitude of the ultra-conservative Orthodox nationalists toward the West is moderately negative. The activists are not outspoken against Europe as such or any other outcome of Western civilisation. However, they loudly express disapproval of certain cultural phenomena from the West, such as gay parades, Harry Potter or Madonna's music. A portrait of the singer was even burned in public, although this was denied by the church authorities, who oppose any aggressive forms of expressing views. ${ }^{54}$

\section{The Central Asian and Caucasian challenge vs the anti-immigrant organisations}

The Orthodox unions were probably the first to realise the new threat to the image of Russia as an Orthodox Christian, East Slavic domain. In the 1990s, Russia was relatively unattractive for hypothetical newcomers. However, after the beginning of the new millennium, the economic situation improved and the metropolitan areas were flooded by 'internal' immigrants from the North Caucasus and workers from the previous Soviet republics of the South Caucasus and Central Asia. Some of the immigrants, especially the Christian Georgians and Armenians, did not cause much of a problem. However, the North Caucasian incomers were associated with crime and Islamic or irredentist terrorism. Similar fears (usually unjustified) were directed toward the Muslim economic migrants from Soviet Central Asia.

This is the background of the emergence of the Movement Against Illegal Immigration (Движение Против Нелегальной Иммиграции, DPNI), which was established in April 2002 by the two Potkin brothers, who assumed the nicknames Vladimir Basmanov (the first co-ordinator) and Aleksandr Belov, his successor between 2008 and 2010 when Vladimir Ermolaev became the chairman of the movement's National Committee. It was recognised by the Moscow City Court as extremist and banned in April 2011 but is still functioning underground. The ideology of the DPNI, supported by political actions and riots such as the anti-Caucasian pogrom in Karelian Kondopoga in August-September 2006, is radically anti-immigrant and generally aims at the eradication of any illegal influence of foreigners in the territory of Russia. Moreover, it postulates the creation of a policy that would support adequate education for Russian citizens so as to avoid the need to accept any qualified or unqualified migrant labour forces. ${ }^{55}$

The DPNI programme contains provisions analogous to those proposed by anti-immigrant groups in Europe and the United States. Among the most 
concrete, we find the postulate to prevent marriages of convenience, which facilitate access to Russia for people representing foreign values. When discussing this topic, the authors of the programme directly refer to solutions used in European countries. ${ }^{56}$

In 2011, the legacy of the DPNI was taken up by The Russians, where the previous DPNI anti-immigrant activists had to share their political convictions with the successors of the Slavic Union.

\section{Conclusions}

There is no doubt that the contemporary forms of Russian nationalism only partially resemble those of the Russian Empire era. The ideological, political, social and economic challenges of the post-Soviet times were different; this is reflected in the shapes which Russian nationalism assumed until the collapse of the USSR. In each of the studied cases, it was possible to identify new, specific challenges for the nation and state, which resulted in a specific continuation of old trends and the emergence of new ones. The final years of communism and the 1990s gave birth to a nostalgic or aggressive form of nationalism, which grew up on the soil of deprivation: the Pamyat' Front, and the sublime conservative-nationalist intellectuals wanted to recreate the previous form of Russia, which was actually a utopian idea because of the completely different historical context.

The trauma of the fallen Red Empire gave rise to the appearance of imperial nationalism. The statist nationalists aimed at the recreation of the Russian Empire with various ideological coatings. Some ideologists, for whom the state defines the nation, created a fifth column in the countries of the 'near abroad'; some, like the LDPR aimed at the reintegration of the USSR without the Marxist doctrine; instead, they proposed Russification. In some cases (such as the Eurasianists or the Izborsky Club), the main preoccupation was to work out a new state idea to combat American leadership and liberal depravity and propose a new icon, where Stalin, one of the worst persecutors of the Orthodox church, runs a choir of Soviet commanders under the patronage of the Holy Virgin.

For those who believed that the collapse of the empire was not the core, but only a consequence of the degeneration of the people, it was necessary to add the ethnic component to the doctrine to find a remedy for bad times. This was the case of RNU; but when the ethnic aspect was absolutised, such phenomena as neo-Nazi organisations were a natural consequence. The ideologies of the Slavic Union or the National People's Party, however, could not respond to the need for a civilisational identity, and thus Shiropaev's initiative to bring Russian nationalism closer to the West revealed a new, 'ethnically European' agreement platform.

Similar attempts to save Russian identity through its religious and folk traditions in the Eurasian storm characterised the 'cultural' trend of nationalistic thought. Even the extreme Orthodox fundamentalists disagreed with 
the Eurasianist temptation, preferring traditional Christian values without resorting to any alliance with the Eastern partners of the Russian nation. The anti-Eastern, especially anti-Islamic option, is the main trait of the DPNI and other smaller groups which follow the example of Le Pen's Rassemblement National and step in line with the Italian Lega, the Dutch Party for Freedom, or Pegida, which respond to the threat of replacing native social orders and values with culturally foreign, usually Islamic, elements.

The Russian nationalism of the post-Soviet times reveals a need for instrumentalist descriptions, since the manipulation of the population's fears and biases was designed to maintain a continual mobilisation and 'geopolitical vigilance. From an alternative perspective, however, the spontaneous voices which grow from the everyday experience call for a research approach that is rooted in the framework of the primordialist paradigm.

The key divergence in the developmental process of contemporary Russian nationalism shows a close correlation with the attitude of individual nationalist circles to Europe in terms of heritage and contemporary manifestations of Europeanness. The imperialist version of Russian nationalism clearly emphasises Europe's hostility towards Russian civilisation, pointing to Western expansionism, including cultural and economic developments, as phenomena resulting from a developed individualism and a spirit of violence. In the case of neo-Eurasianism, we are even dealing with a geopoliticalmystical juxtaposition of Western Atlanticism (as the den of degenerate capitalism, progressivism, abolition of obligations towards communities) and continental Eurasia, the land of tradition, communitarian sacrifice and state subsidiarity. In the 'great power' vision, Europe is seen as part of the Atlantic power, which justifies the intention to diminish Western influence and make Russia an equal partner in international relations.

'Cultural' nationalism, including religious nationalism, despite recognising obvious differences, does not perceive Europe as a significant problem. It sees the real threat rather in the internal weakening of traditional commitments. On the other hand, racist, ethno-nationalist and anti-immigrant circles resort to some European inspirations, and sometimes even refer to the symbols and nomenclature of the European radical right. The most radical pro-Westernism is characterised by the national democrats, who seem to have gained some popularity in recent years.

One has to remember that the criticism of Europe presented by imperialistic nationalists in Russia is not a straightforward but rather a reversed equivalent of the nationalistic radical movements in Western Europe. European extreme right-wingers in France, Germany, the Netherlands or Italy seem to present views that resemble Russian ethno-nationalistic ideas: the need to appreciate regional traditions or a hostility toward immigration from Muslim states. The Kremlin eagerly supports these groups (not only with friendly rhetoric, but also with financial resources). Why, then, does it act in the exact opposite manner at home, fighting its own ethnic nationalism and only leaving room to imperialists who are clearly hostile to the West? The reason seems to be the 
intention to destabilise the situation in European countries and weaken the structures of the EU. ${ }^{57}$

It is not easy to predict the future direction of Russian nationalism. The theoretically critical attitude of a significant part of the society towards a centralised and corrupt government and towards immigration from neighbouring Muslim countries may lead to the strengthening of ethnic nationalism at the expense of the imperial trend. On the other hand, however, demographic processes leading to the extinction of the Slavic and Finno-Ugric elements and to a significant increase in the share of the nations traditionally professing Islam may lead to a further weakening of the ties between Russia's population and European heritage.

\section{Notes}

1 Andrzej Walicki, The Slavophile Controversy: History of a Conservative Utopia in Nineteenth-Century Russian Thought, (University of Notre Dame Press 1989).

2 Walter Laqueur, Black Hundred: the Rise of the Extreme Right in Russia, (HarperCollins 1993). For a deeper insight into the topic of Black Hundred itself see Сергей Степанов, Черная Сотня: что они сделали для величия России, (Яузапресс 2013).

3 Frederick Charles Barghoorn, Soviet Russian Nationalism, (Oxford University Press 1956).

4 Yitzak Brudny, Reinventing Russia: Russian Nationalism and the Soviet State, (Harvard University Press, Cambridge, Mass. 2000). A new light on the 'Russian Party' in the top Communist circles of the USSR was cast thanks to A. Baygushev's book about the nationalistic inside job in the time of stagnation: Александр Байгушев, Партийная разведка, (Алгоритм 2007).

5 John B Dunlop, The Faces of Contemporary Russian Nationalism, (Princeton 2014).

6 Pal Kolstø and Helge Blakkisrud (ed), The New Russian Nationalism: Imperialism, Ethnicity and Authoritarianism 2000-15, (Edinburgh University Press 2016).

7 Marlène Laruelle, Russian Nationalism: Imaginaries, Doctrines, and Political Battlefields, (Routledge 2018).

8 Kolstø and Blakkisrud, (n 6), 22-23.

9 Лабиринт. База данных, 'Рождение общества Память', (Лабиринт, 16 February 1998), www.labyrinth.ru/content/card. asp?cardid=36234 accessed 21 June 2020.

10 Валентин Новиков, 'Публицистика: Вячеслав Овчинников: Начнем хотя бы с малых дел', http://sp.voskres.ru/publicistics/ovch.htm accessed 21 June 2020.

11 Дмитрий Васильев, 'Что-то с памятью моей стало', (Новый взгляд 15 August 1992), www.newlookmedia.ru/?p=1586 accessed 21 June 2020.

12 Александр И. Солженицын, Как нам обустроить Россию, 'Комсомольская правда', Специальный выпуск, 18 September 1990.

13 Александр И. Солженицын, Россия в обвале, (Русский путь 1998).

14 Александр И. Солженицын, Двести лет вместе (1795-1995), (Русский путь 2001).

15 Александр И. Солженицын, Письмо вождям Советского Союза, (YМСА Press 1974).

16 Александр И. Солженицын, Раскаяние и самоограничение, Из-под глыб, (YMСА Press 1974), 120-127. 
17 Александр И. Солженицын, 'Сбережение народа - высшая изо всех наших государственных задач’, (Interview), (Московские новости 28 April 2006), https:// web.archive.org/web/20120125144532/http://yavlinsky.ru/theme_of_day/index. phtml?id=2860 accessed June 262020.

18 Aleksandr I Solzhenitsyn, A World Split Apart, Address delivered on 8 June 1978, Harvard University, www.americanrhetoric.com/speeches/aleksandr solzhenitsynharvard.htm accessed 21 June 2020.

19 Ibid.

20 Александр И. Солженицын, Двести лет вместе, (Русский путь, vol. 1: 2001), $507 \mathrm{nn}$.

21 Игорь Р. Шафаревич, Трехтысячелетняя загадка, (Эксмо, Алгоритм 2005).

22 Игорь Р. Шафаревич, Русофобия, (Российское Национальное Объединение 1989).

23 Игорь Р. Шафаревич, Трехтысячелетняя загадка, (Эксмо, Алгоритм 2005), 412-413.

24 Игорь Р. Шафаревич, Русофобия, (Вече 1988), 22-29.

25 Игорь Р. Шафаревич, Зачем России Запад?, (Эксмо, Алгоритм 2005), 23-24, 57.

26 Ibid., 60, ff.

27 Ibid., 102.

28 Игорь Р. Шафаревич, 'Две дороги - к одному обрыву', http://shafarevich.voskres. ru/a28.htm accessed 27 June 2021. First published in Новый мир, 1989, № 7.

29 ЛДПР, 'Мы за русских! 111 позиций ЛДПР', https://ldpr.ru/events/We_are_111_ positions_for_the_Russian_Liberal_Democratic_Party/

30 Владимир В. Жириновский, Россия и Европа: история непонимания, (ЛитРес 2019), 3, www.litres.ru/static/or4/view/or.html?baseurl=/download_ book $/ 48621060 / 60720610 / \&$ art $=48621060 \&$ user $=896609752 \&$ uilang $=$ ru $\&$ catalit2\&track_reading accessed 27 June 2021.

31 Дмитрий Рогозин, 'Главный принцип национальной политики - люби свое, уважай чужое', https://pozneronline.ru/2020/11/30252/ accessed 21 June 2021.

32 Великая Россия, 'Программа Партии «Великая Россия»', http://velikoross.org/ programm/ accessed 21 June 2020.

33 Русская доктрина. Сергиевский проект, 'Тезисы Русской доктрины', www. rusdoctrina.ru/page95509.html accessed 21 June 2020.

34 Андрей Н. Колев, Нация и государство, (Логос 2005), 403-404.

35 Ideas represented in many works, e.g. in Aleksandr Dugin's Foundations of Geopolitics: Александр Дугин, Основы геополитики, (Арктогея 1997).

36 Изборский клуб, 'О клубе', https://izborsk-club.ru/about accessed June 232020.

37 Александр А. Проханов, В поисках русской мечты, (Книжный мир 2019).

38 Marlène Laruelle, 'The Izborsky Club, or the New Conservative Avant-Garde in Russia', (2016), The Russian Review, 75, 626-627, 643-644.

39 Александр Дугин, Основы геополитики, (Арктогея 1997), 220 ff.

40 Александр П. Баркашов, Азбука русского националиста, (Слово-1, 1994).

41 Владимир Прибыловский, Вячеслав Лихачев, Русское Национальное Единство, (Центр «Панорама» 2000), 82, nn.

42 John B Dunlop, 'Alexander Barkashov and the Rise of National Socialism in Russia', (1996), 4, Demokratizatsiya, 4, 519-530.

43 Comp. Александр Верховский, Галина Кожевникова (Eds), Радикальный русский национализм: структуры, идеи, лица, (РОО Центр «Сова» 2009), 155-156.

44 Олег Колосов, 'Почему Демушкина послали нах европейские националисты?', LiveJournal, https://rons-inform.livejournal.com/2393203.html accessed 21 June 2021. 


\section{Joachim Diec}

45 Александр К. Иванов (Сухаревский), 'Три источника русизма', https://web. archive.org/web/20120821100103/http://nnpr.su/stat/iv/triist.htm accessed 27 June 2020.

46 Алексей А. Широпаев, Тюрьма народа: русский взгляд на Россию, (Москва 2001).

47 Национал-Демократический Альянс, 'Общая информация', https://vk.com/naz dem accessed 21 June 2020.

48 'Русский националист: Россия - это Европа' Activatica, http://activatica.org/blogs/ view/id/2827/title/russkiy-nacionalist-rossiya-jeto-evropa accessed 21 June 2021.

49 Аналитический центр Юрия Левады, Россия и Европа, www.levada.ru/2021/03/ 18/rossiya-i-evropa-2/ accessed 23 Mar 2021.

50 Россия Освободится Нашими Силами, 'О движении', http://ronsslav.com/o-nas/ accessed 21 June 2020.

51 Comp. Comp. Лариса А. Андреева, 'Феномен религиозного индифферентизма в Российской империи’, (2008), 4, Общественные науки и современность, 114-124.

52 The original pre-revolutionary spelling placed on the website is preserved: ' $\mathrm{O}$ Союзе Православных Хоругвеносцев', www.pycckie.org/info/index.shtml accessed 21 June 2020.

53 Pew Research Center, 'Religious Belief and National Belonging in Central and Eastern Europe', (10 May 2017), https://pewrsr.ch/3dqJEMU accessed 21 June 2020.

54 See: Ирина Кислина, Ксения Кириллова, 'Кто такие православные хоругвеносцы? Правмир, 11 August 2012, www.pravmir.ru/kto-takie-pravoslavnye-xorugvenoscy/ accessed 21 June 2021.

55 ДПНИ, 'Цели и задачи', https://web.archive.org/web/20060818014009/http://www. dpni.org/index.php?2 accessed 21 June 2020.

56 Программа движения против нелегальной иммигращии, http://lindex-ru.org/Lind ex5/Text/10930.htm accessed 21 June 2021.

57 The question of connections between radical right-wing movements in the West and the Kremlin's activity was aptly touched upon in Anton Shekhovtsov, Russia and the Western Far Right, (Routledge 2018). 


\section{Part III}

\section{Right-wing populist attitudes towards the $\mathbf{E U}$}




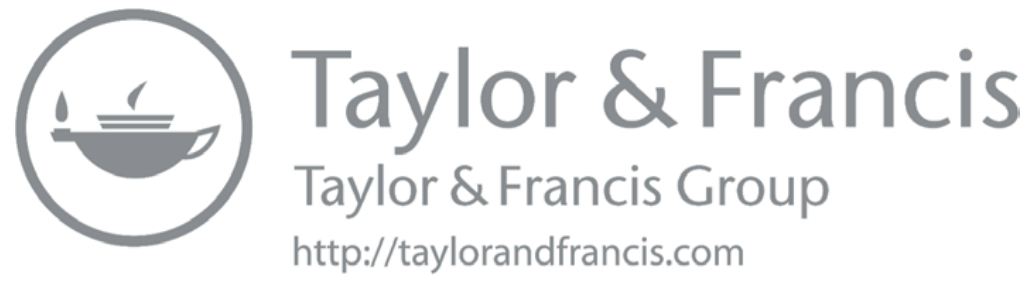




\title{
13 United in diversity? \\ The preferences of populist parties in the European Parliament
}

\author{
Giorgia Nesti and Paolo Graziano
}

\section{Introduction}

Nationalists, populists and anti-European parties entered the European Parliament in 2014 and since then have gained important electoral results in almost all European states. These parties emerged as new political actors since they were able to capitalise on citizens' discontent toward the economic crisis, distrust towards political institutions and to take advantage of the "window of opportunity' provided by the redefinition of Western political and party systems. ${ }^{1}$

Their increased relevance on the political scene has attracted the attention of several scholars; nevertheless, while research about electoral campaigns, voter motivations and party families abound, very little is known about the attitude of populists towards European policies. The chapter aims to fill this gap by looking at how populist parties voted on some dossiers during the VIII Parliamentary term (2014-2019) in order to assess what their attitude was towards European issues, whether they were able to influence ballots, and whether they have been cohesive in contesting the European Union (EU).

\section{Defining populism}

Notwithstanding the fact that populism has been attracting academic attention for years, there is still no commonly accepted definition. In one of the most influential publications on populism, Mudde defines populism as

a thin-centered ideology that considers society to be ultimately separated into two homogeneous and antagonistic groups, 'the pure people' versus 'the corrupt elite', and which argues that politics should be an expression of the volonté générale (general will) of the people. ${ }^{2}$

In line with this definition, populist messages would be characterised by: 1) a sharp criticism of the elites and the establishment; 2) the importance attached to the concept of popular sovereignty; 3 ) the belief that people are misrepresented in politics. ${ }^{3}$ 
Caiani and Graziano ${ }^{4}$ proposed that populism represents a multifaceted concept. It can, in fact, designate:

1 An ideology that contrasts the virtues of the 'people' against the 'establishment' or the 'ruling elite'.

2 A rhetoric which de-legitimises old mainstream parties and their proposals and supports new political actors.

3 An informal communication style that proposes easy solutions to complex problems.

4 A political organisation characterised by a concentration of power in the hands of a leader and by a personalisation of the relationship between a party leader and party members.

Yet populism is far from being a homogeneous political concept. In the academic literature, authors distinguish between right-wing and left-wing populist movements. For Abts and Rummens, ${ }^{5}$ right-wing populism refers to the ethnic nation, whereas left-wing populism identifies the 'people' in socio-economic terms, such as the working class exploited by the bourgeois elite. Within right-wing populists, Zulianello ${ }^{6}$ identifies populist radical right parties, Mudde ${ }^{7}$ neoliberal populists, and Pankowski and Kormak ${ }^{8}$ national-conservative populists. More specifically, for Falkner and Plattner ${ }^{9}$ populist radical right parties are 'populist' because they represent themselves as the unique legitimate representatives of the people or, in Kriesi's words: they "mobilize in the name of "the people"'. ${ }^{10}$ They are radical because they oppose some principles of liberal democracy such as 'pluralism and the constitutional protection of minorities', ${ }^{11}$ and they can be placed on the right side of the political spectrum because they believe 'the main inequalities between people to be natural and outside the purview of the state'.12

Left-wing populists, on the other side, merge populism with variously defined forms of socialism and, therefore, they can be classified as social populists and national-social populists ${ }^{13}$ as they combine left-wing populist claims with nationalism.

This dual categorisation of populism, nevertheless, is still not exhaustive as it is incapable of grasping more nuanced types of populism such as that expressed by the Italian Five Star Movement (FSM). Caiani and Graziano, for instance, define it as a form of 'hybrid populism', ${ }^{14}$ since FSM 'adopts an ideologically eclectic mix of policy positions and does not clearly locate itself on either the left or the right flank of the party system'. ${ }^{15}$ Similarly, Zulianello refers to FSM as a form of 'valence populism' since it 'predominantly, if not exclusively, compete[s] by focusing on non-positional issues such as the fight against corruption, increased transparency, democratic reform and moral integrity, while emphasising anti-establishment motives' ${ }^{16}$ To cope with this theoretical challenge, we decide to follow Caiani and Graziano's approach, ${ }^{17}$ which moves beyond the traditional left-wing/ right-wing political 
continuum and distinguishes between inclusionary and exclusionary populism..$^{18}$ Inclusionary and exclusionary populism identifies a different way of defining the 'other(s)'; it refers to a different idea about how resources should be distributed among social groups; and it appeals to forms of political mobilisation that go beyond representative democratic channels. In inclusionary European populism, the 'other' is represented by the economic oligarchy, the media, the judiciary and foreign capital. In exclusionary European populism, the 'other' is mostly formed of immigrants and people who are 'culturally different'.

\section{Populists and the European Union}

All European populist parties promote a form of Euroscepticism that ranges between hard and soft positions. This attitude stems from the underlying idea that the EU has produced economic inequalities and a cultural clash due to its subjugation by neoliberal globalisation, the promotion of progressive social values - among which are racial and gender equality - and multiculturalism. ${ }^{19}$

Following their 'anti-elite rhetoric', populist parties usually support 'the Europe of peoples' vs 'the Europe of institutions', the latter being a project run by European political elites and big member states against masses and small and less powerful member states ${ }^{20}$. Thus, in general terms, they express a disagreement with European policies, political elites and values ${ }^{21}$.

More precisely, exclusionary populists are usually hard Eurosceptic as they heavily oppose European integration and the euro. They are typically nationalists, xenophobic and anti-immigration, and they also adopt a clear anti-establishment stance since EU institutions and leaders are considered responsible for inaction, or 'wrong' actions under austerity. ${ }^{22}$ On the other side, inclusionary populists tend to be soft Eurosceptics. They oppose European integration and are critics of the European Commission, the European Central Bank and lobbies; they also deplore the EU's lack of transparency and its corruption. But they are in favour of immigration and of a stronger role for the EU in security.

With reference to Italian parties, the Northern League (NL) and FSM adopt a populist anti-European attitude while Forza Italia (FI) is in favour of EU membership. ${ }^{23}$ For the NL, the European people are inherently uncorrupted against European institutions - particularly the European Commission (EC) and the European Central Bank (ECB). 'The EU process as a whole is represented very negatively (a 'deception') as the product of an anti-democratic global ideology, aiming at the dismantling of the European system of social rights'. ${ }^{24}$ FSM is against the European oligarchy as well ('AmericanEnglish-German finance') while FI represents the EU as 'an instrument to support and reinvigorate freedom'..$^{25}$

An important aspect of the position adopted by populist parties towards the European Union emerges during European electoral campaigns. Populist 
parties, in fact, usually attack the EU and claim they would change its policies from the inside during their mandate. Remarkably, whilst there is a tremendous body of literature on populist electoral campaigns and messages about the European Union, ${ }^{26}$ literature on the behaviour of these parties inside the European Parliament (EP) is still scarce (for an exception to this rule see De Lange et al.). ${ }^{27}$ Our contribution aims at analysing this aspect by assessing whether populist parties elected to the EP have adopted a critical attitude towards European issues, whether they were able to influence the adoption or rejection of dossiers though their voting behaviour, and whether they were cohesive in contesting the EU as populist groups.

\section{Methodology and data}

In order to answer to our research questions, we analysed how populist parties elected to the EP voted during the VIII Parliamentary term (2014-2019) on some specific issues - privatisation of water, reduction of car emissions, gender equality, and immigration. We selected these four dossiers because they represent critical cases ${ }^{28}$ of contentious issues voted on in the EP plenary for which we found data on ballots available on the VoteWatch database (see endnote 30). Furthermore, these are cases where a 'populist' (i.e. against the élite) position can easily be hypothesised, and where the nuances between the two types of populism (inclusionary vs. exclusionary) could also be hypothesised (as in the case of gender equality and immigration). For each dossier we analyse: 1) if each MEP of populist parties cast a roll-call vote in favour or against the legislative act under discussion in the EP plenary; and 2) whether the national party was loyal to the European political group, i.e. whether the national party voted following the indication expressed by the European political group it belonged to or if it was a 'rebel', i.e. it did not follow the voting indication.

European populist parties were classified according to the inclusionary/ exclusionary criterion. ${ }^{29}$

For each dossier we counted the number of votes expressed by each MEP in each national populist party and we classified them along four categories: for, against, abstention, no vote. We assigned the party to the category according to votes expressed by the majority of MEPs. If a majority was not identifiable, we did not assign a party to any specific category, but we mention it in the comments attached to the tables.

The votes cast by each party in the EP were collected from the VoteWatch Europe database, ${ }^{30}$ while explanations of MEPs' votes were extracted from documents available on the EP website.

Due to its exploratory nature and the use of mere descriptive statistics, our research clearly suffers from the limitation of external validity. Nevertheless, in our opinion, it proves useful in order to initiate a discussion on voting behaviour inside the EP as a proxy of the real attitude of populist parties towards European policies outside of the rhetoric they espouse. 


\section{Populist parties in the European Parliament}

The 2019 European parliamentary elections raised concerns among several observers about the possible wins by Eurosceptic, nationalist and populist parties. ${ }^{31}$ Remarkably, even though the elections testified to a dramatic increase in electoral participation after almost 20 years of decline, ${ }^{32}$ antiEuropean parties did not perform any better than five years previously, and mainstream parties performed relatively well. ${ }^{33}$ While 'mainstream' parties gained $75 \%$ of the EP seats in $2014(=$ n. 566), in 2019 they lost only $4 \%$ of seats $(=$ n. 33). Exclusionary populist parties gained 148 seats out of 749 in $2014(=19.75 \%)$ and 178 out of 751 in $2019(=23.7 \%)$ while inclusionary populists gained 35 seats in $2014(=4.65 \%)$ and 40 seats in $2019(=5.02 \%)$. Hence, in total, populists gained $4.6 \%$ of seats with reference to 2014 (see Tables 13.1 and 13.2).

If we look at the composition of European party groups (see Table 13.3), we can observe that four exclusionary populist parties which were members of the group Europe of Nations and Freedom (ENF) in 2014 moved to the new group Identity and Democracy (ID), three from the European Conservatives and Reformists Group (ERC) moved to ID, one party moved to the European Popular Party (EPP) while one party belonging to the group Europe of Freedom and Direct Democracy (EFDD) moved to the non-attached members (NI). Finally, the Alliance of Liberals and Democrats for Europe (ALDE) was transformed into the Renew Europe group. Interestingly, whilst the total net gain in terms of seats of populists was limited, some national parties performed quite well in the 2019 elections, such as the Italian NL that increased from 5 to 28 seats, the Polish Law and Justice (PiS) that increased from 19 to 26 seats, and Alternative for Germany that increased from 7 to 11 seats. Among the inclusionary populist parties, Syriza did not increase its

Table 13.1 Populist parties' seats in the EP (VIII and IX legislatures)

\begin{tabular}{lrrc}
\hline Seats & 2014 & 2019 & Var.\% \\
\hline Exclusionary & 148 & 178 & +3.95 \\
Inclusionary & 35 & 40 & +0.65 \\
Total & 183 & 218 & +4.60 \\
\hline
\end{tabular}

Table 13.2 Number of populist parties in the EP (VIII and IX legislatures)

\begin{tabular}{lrc}
\hline Parties & 2014 & 2019 \\
\hline Exclusionary & 24 & 23 \\
Inclusionary & 5 & 8 \\
Total & 29 & 31 \\
\hline
\end{tabular}


Table 13.3 Populist parties in the EP (VIII and IX legislatures)

\begin{tabular}{|c|c|c|c|c|c|c|c|}
\hline Country & Populist Party & $A b b r$. & $\begin{array}{l}\text { Type of } \\
\text { populism } \\
\text { (inclusionary/ } \\
\text { exclusionary) }\end{array}$ & $\begin{array}{l}\text { EP group } \\
2014\end{array}$ & $N$. seats & $\begin{array}{l}\text { EP group } \\
2019\end{array}$ & N. se \\
\hline Austria & Freedom Party of Austria & FPÖ & Exclusionary & ENF & 4 & ID & 3 \\
\hline Belgium & Flemish Interest - Vlaams Belang & VB & Exclusionary & ENF & 1 & ID & 3 \\
\hline Bulgaria & $\begin{array}{l}\text { Citizens for European Development } \\
\text { of Bulgaria }\end{array}$ & GERB & Exclusionary & EPP & 6 & EPP & 6 \\
\hline Bulgaria & $\begin{array}{l}\text { Bulgaria Without Censorship/ } \\
\text { Reload Bulgaria }\end{array}$ & BBT-BBZ & Exclusionary & ECR & 2 & - & 0 \\
\hline Croatia & Human Shield & $\mathrm{ZZ}$ & Inclusionary & - & 0 & NI & 1 \\
\hline Czech Republic & ANO 2011 & ANO 2011 & Exclusionary & ALDE & 4 & $\begin{array}{l}\text { RENEW } \\
\text { EUROPE }\end{array}$ & 6 \\
\hline Czech Republic & $\begin{array}{l}\text { Dawn of direct democracy/ National } \\
\text { Coalition }\end{array}$ & USVIT & Exclusionary & - & 0 & NI & 2 \\
\hline Denmark & Danish People’s Party & DF & Exclusionary & ECR & 4 & ID & 1 \\
\hline Estonia & $\begin{array}{l}\text { Estonian Reform Party/ } \\
\text { Conservative People's Party }\end{array}$ & EKRE & Exclusionary & - & 0 & ID & 1 \\
\hline Finland & Finns Party//True Finns & PS & Exclusionary & ECR & 2 & ID & 2 \\
\hline France & National Front & FN & Exclusionary & ENF & 24 & ID & 22 \\
\hline France & Unbowed France & LFI & Inclusionary & - & 0 & GUE/NGL & 6 \\
\hline Germany & Alternative for Germany & AfD & Exclusionary & ECR & 7 & ID & 11 \\
\hline Germany & Left Party & LINKE & Inclusionary & GUE/NGL & 7 & GUE/NGL & 5 \\
\hline Germany & $\begin{array}{l}\text { National Democratic Party of } \\
\text { Germany }\end{array}$ & NPD & Exclusionary & NI & 1 & - & 0 \\
\hline Greece & Greek Solution & EL & Exclusionary & - & 0 & ECR & 1 \\
\hline Greece & Coalition of the Radical Left & SYRIZA & Inclusionary & GUE/NGL & 6 & GUE/NGL & 6 \\
\hline Greece & Independent Greeks & ANEL & Exclusionary & ERC & 1 & - & 0 \\
\hline Greece & Golden Dawn & GD & Exclusionary & NI & 3 & NI & 2 \\
\hline
\end{tabular}


m- n

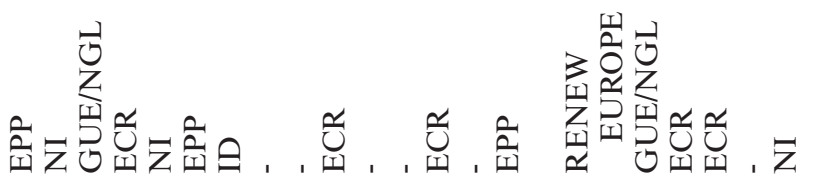

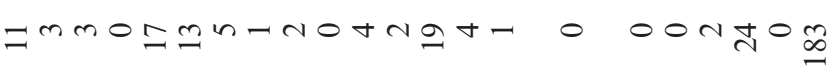

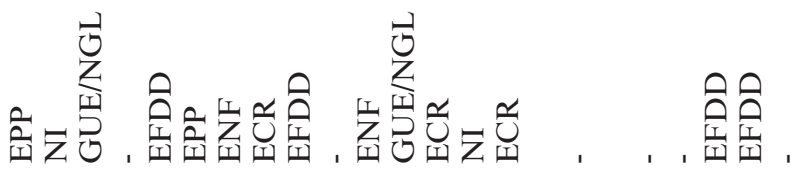

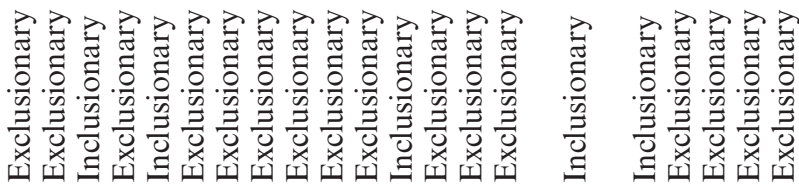

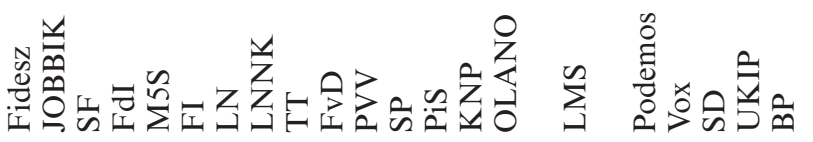

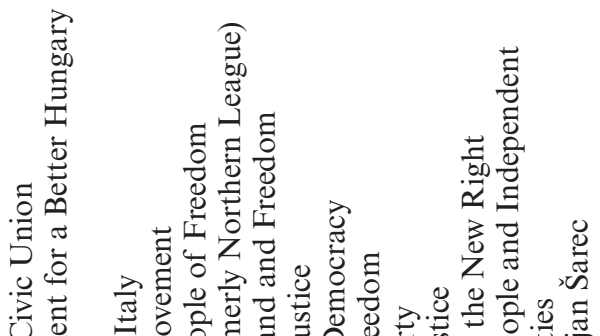

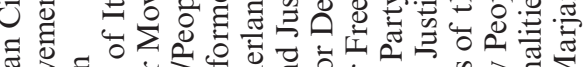

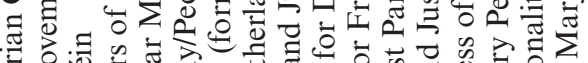

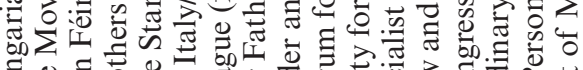

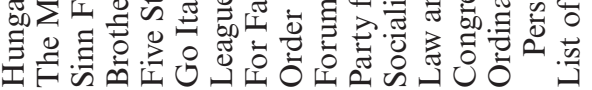

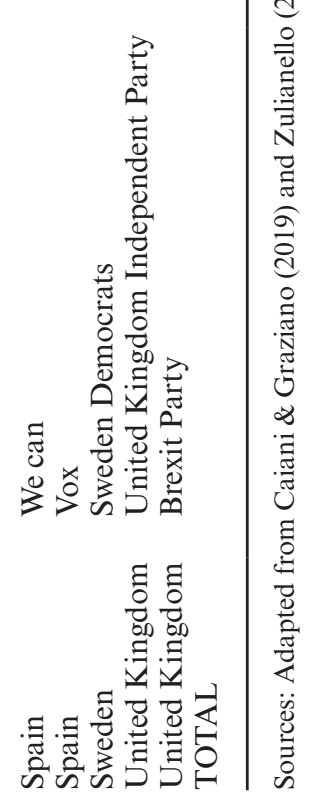

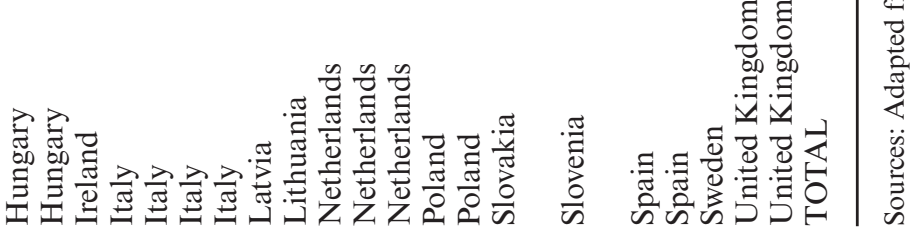




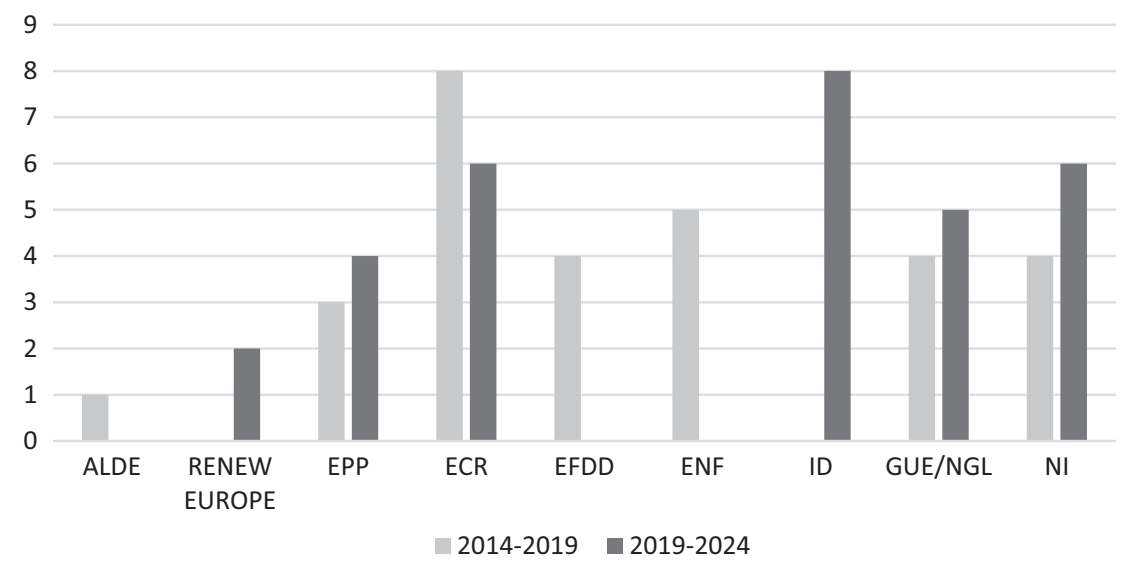

Figure 13.1 Number of populist parties in each European political group (VIII and IX legislatures).

seats, FSM lost three seats but Podemos won five extra seats. The number of populist parties represented in the EP rose from 29 to 31 in 2019 but, interestingly, this was mainly due to the fact that the number of inclusionary populist parties increased by three units while the number of exclusionary parties decreased by one unit.

If we look at Figure 13.1 we can see that in the VIII Legislature the majority of inclusionary populist parties (= 4 out of 5) were members of the radical left group GUE/NGL while FSM was a member of the EFDD group. Exclusionary populist parties were split among different right-wing groups with a slight majority of them concentrated into the ECR group (= n. 8). In the current legislature, the majority of inclusionary groups are members of GUE/NGL (5 out of 8) but two parties are now in the NI group ( $\mathrm{ZZ}$ and FSM) and one is a member of Renew Europe (LMS). Exclusionary populists are still split among right-wing groups, but they are now more concentrated in the ID new group ( 8 out of 23), ECR (6 out of 23), EPP (4 out of 23), NI (4 out of 23) and Renew Europe (1 out of 23).

As we will see in the final section of this contribution, the decision to adhere to a political group in the EP is extremely relevant in terms of political weight inside party coalitions and voting strategy.

\section{Populist parties and voting behaviour in the European Parliament: four case studies}

The literature on the EP highlighted that party behaviour is mainly influenced by left-right ideology and that conflicts usually arise on economic issues due to the nature of the competence of the EP on the Internal Market. ${ }^{34}$ Moreover, 
Hix and Noury ${ }^{35}$ found that the majority of MEPs vote increasingly along transnational party lines, while MEPs from Central and Eastern Europe tend to vote slightly more along national lines and that cohesion of European political groups has increased.

Previous research on right-wing populist parties pinpointed that they are not a unitary group and that their voting behaviour is less coherent than other transnational parties. ${ }^{36}$ Exclusionary populist parties have, in fact, different ideological orientations that can be hard to reconcile; therefore, during the VIII legislature, these parties were not able to form a unitary group.

Moreover, exclusionary populists manifested a low degree of cohesion when voting. ${ }^{37}$

\section{Right2 Water}

On 8 September 2015 a Motion for Resolution that called on the Commission to come forward with legislative proposals that would recognise universal access and the human right to water and that pushed for the exclusion of water services from trade agreements was voted on. The Motion followed the Right2Water European citizens' initiative (ECI). The text regretted that the Communication from the Commission did not meet the specific demands made in the initiative and that the response given by the Commission to the Right2Water ECI was insufficient.

The majority of the Members of the European Parliament (MEPs) voted for its adoption (363 votes, 53\%), 96 MEPs voted against (14\%), and 231 abstained (33\%). The majority was formed by S\&D, GUE and Greens and EFDD (among which was FSM). MEPs from inclusionary populist parties all voted for the motion to support public water while MEPs from exclusionary populist parted adopted different positions (see Table 13.4). They mainly voted against the resolution, following the voting indication made by ERC and ENF but PiS abstained, BBT-BZZ didn't vote, while VB, FPO, ANEL OLANO and NL voted for. One MEP from AFD abstained and the other one didn't vote. Yet the EFDD group, indicated that it would vote for the Motion, but UKIP voted against. Exclusionary populists supported it because they were against privatisation, like NL. MEPs who abstained or voted against complained that the text was too superficial and did not sufficiently explain the EP's position on water privatisation.

Table 13.4 Populist parties' positions (Right2Water)

\begin{tabular}{lrlll}
\hline & For & Against & Abstentions & No Vote \\
\hline Inclusionary & 5 & 0 & 0 & 0 \\
Exclusionary & 9 & 8 & 5 & 1 \\
Total & 14 & 8 & 6 & 0 \\
\hline
\end{tabular}


Table 13.5 Loyalty/rebellion of populist parties (Right2Water)

\begin{tabular}{lcl}
\hline & Loyal & Rebel \\
\hline ALDE & 1 & 0 \\
EPP & 3 & 0 \\
ECR & 3 & 5 \\
GUE & 4 & 0 \\
EFDD & 3 & 1 \\
ENF & 2 & 3 \\
Total & 16 & 9 \\
\hline
\end{tabular}

Hence the majority of populist parties were loyal to their political groups, like all parties belonging to ALDE, GUE/NGL and the EPP, and the majority of parties belonging to the EFDD. Among the exclusionary populists, nevertheless, there were some rebel parties like those within ECR and ENF (see Table 13.5).

\section{Car emissions}

On 3 January 2016, MEPs voted on the Parliamentary objection pursuant to Rule 106 on emissions from light passenger and commercial vehicles (Euro 6) on a draft Commission regulation amending Regulation (EC) No 692/ 2008 as regards emissions from light passenger and commercial vehicles (Euro 6). The Commission proposed raising diesel car emission limits by up to $110 \%$ as part of a package to introduce the Real Driving Emissions (RDE) test procedure ${ }^{38}$ but the Parliament issued an objection supported by a coalition made up of the Socialists, Greens/EFA, GUE-NGL and ALDE, who argued that the plans to relax the limits would weaken the enforcement of existing EU standards. The objection was rejected with 323 votes $(46 \%)$ from the EPP and ENF against 317 (45\%) votes for and 61 abstentions. Exclusionary populists, in fact, rebuffed the Objection since they considered it exceeded EU competences and supported the Commission's proposal. Inclusionary populists who proposed the Objection considered the text of the Regulation to be the result of a strong lobbying action mounted by the car industry.

Remarkably, while inclusionary populists voted as a whole for the Objection, exclusionary populists expressed different positions. The majority of them were against it but BBT-BZZ, PS, AFD, ANEL, FSM and FPÖ voted for, while LNNK didn't vote (see Table 13.6).

Inclusionary populists from GUE/NGL were loyal to their group but FSM was not, since the EFDD had directed members to abstain. Populist parties belonging to ALDE, ERC, ENFF and ENF voted in a less cohesive way (see Table 13.7). 
Table 13.6 Populist parties' positions (car emissions)

\begin{tabular}{lccll}
\hline & For & Against & Abstentions & No Vote \\
\hline Inclusionary & 5 & 0 & 0 & 0 \\
Exclusionary & 8 & 11 & 3 & 1 \\
Total & 13 & 11 & 3 & 1 \\
\hline
\end{tabular}

Table 13.7 Loyalty/rebellion of populist parties (car emissions)

\begin{tabular}{lcc}
\hline & Loyal & Rebel \\
\hline ALDE & 0 & 1 \\
EPP & 3 & 0 \\
ECR & 3 & 5 \\
GUE & 4 & 0 \\
EFDD & 2 & 2 \\
ENF & 3 & 2 \\
Total & 15 & 10 \\
\hline
\end{tabular}

\section{Gender equality}

On 3 March 2015, the EP voted on the Motion of a Resolution based on the Report prepared by the Women's Rights Committee on progress on equality between women and men in the European Union in 2013. The report called on member states and the European Commission to mainstream gender in all policies, to fight against female poverty, social exclusion and gender violence, to promote the equal participation of men and women in the labour market and within decision-making institutions, to reduce the gender pay gap and pension gap, and finally to combat gender stereotypes. A controversial issue was the legalisation of abortion and the improvement of women's access to sexual and reproductive health services. In Recital 44, in fact, the Report maintained that 'women must have control over their sexual and reproductive health and rights, not least by having ready access to contraception and abortion'.

The Motion was supported by a left coalition made up of S\&D, Greens, GUE/NGL, ALDE, half of the EPP and FSM and passed with 441 votes for (63\%), 205 against (29\%), and 52 abstentions (7\%).

Inclusionary populists were all in favour of the Motion, apart from Sinn Fein which abstained. Exclusionary populists voted against the Motion as they did not approve the mention of quota systems to increase representation in institutions or abortion legalisation. But GERB, ANEL, and SD voted for it, while ANO 2011 abstained. Within the EPP, half of MEPs from FI 
Table 13.8 Number of votes expressed by populist parties (gender equality)

\begin{tabular}{lllll}
\hline & For & Against & Abstentions & No Vote \\
\hline Inclusionary & 4 & 0 & 1 & 0 \\
Exclusionary & 3 & 16 & 3 & 0 \\
Total & 7 & 16 & 4 & 0 \\
\hline
\end{tabular}

Table 13.9 Loyalty/rebellion of populist parties (gender equality)

\begin{tabular}{lcl}
\hline & Loyal & Rebel \\
\hline ALDE & 0 & 1 \\
EPP & 1 & 2 \\
ECR & 7 & 1 \\
GUE & 4 & 0 \\
EFDD & 1 & 3 \\
ENF & 5 & 0 \\
Total & 18 & 7 \\
\hline
\end{tabular}

voted for the Motion and half against. Within EFDD, one MEP from TT voted against the Motion and one abstained. Of the three MEPs from Jobbik (NI) one voted against the Motion, one abstained and one did not vote (see Table 13.8).

Once again, inclusionary populists voted compactly while exclusionary populists, apart from groups in ENF, were split among different positions. Rebels were present in the EPP that indicated they would vote against the Motion, and in the EFDD that called for abstention (see Table 13.9).

\section{Immigration}

On 9 September 2015, MEPs voted on the Joint Motion for a Resolution on Migration and Refugees in Europe, on refugee relocation and resettlement, calling on the Commission to amend the Dublin Regulation to include a permanently binding system for the distribution of asylum seekers among the 28 member states. The resolution asked member states and the EU to prevent refugees' deaths, to show solidarity and to share responsibilities in managing the refugee crisis.

The text was adopted with 432 votes in favour, 132 against and 57 abstentions. The Motion was supported by S\&D, GUE/NGL, the Greens together with EPP, and ALDE. All of the inclusionary parties voted for the Motion, apart from SD, which did not vote on it. Almost all of the exclusionary populist parties voted against it (see Table 13.10) since they did not accept the relocation mechanisms proposed by the Commission. 
Table 13.10 Number of votes expressed by populist parties (immigration)

\begin{tabular}{lllll}
\hline & For & Against & Abstentions & No Vote \\
\hline Inclusionary & 4 & 0 & 0 & 1 \\
Exclusionary & 3 & 19 & 1 & 1 \\
Total & 7 & 19 & 1 & 2 \\
\hline
\end{tabular}

Table 13.11 Loyalty/rebellion of populist parties (immigration)

\begin{tabular}{lcl}
\hline & Loyal & Rebel \\
\hline ALDE & 0 & 1 \\
EPP & 2 & 1 \\
ECR & 7 & 1 \\
GUE & 3 & 1 \\
EFDD & 2 & 2 \\
ENF & 5 & 0 \\
Total & 19 & 6 \\
\hline
\end{tabular}

Populist parties were basically loyal toward their political groups, but some defections occurred. ALDE and the EPP supported the Commission's proposal so they indicated that they were going to vote for the Motion but ANO 2011 and Fidesz voted against; EFDD and ECR indicated to vote against the Motion because they did not accept the relocation mechanism, but ANEL and FSM voted for it while TT abstained (see Table 13.11).

Interestingly, VoteWatch reported that in the EPP, MEPs from Fidesz voted against the motion and MEPs from the Poland delegation abstained. ${ }^{39}$

\section{Discussion and conclusions}

The analysis of the roll-call votes expressed by populist parties in the EP on the Motions for resolutions concerning the privatisation of water, reduction of car emissions, gender equality, and immigration highlight some similar patterns. Motions were usually aimed at promoting citizen and consumer rights and at protecting the environment and were supported by the centreleft coalitions made up of S\&D, the Greens, EPP and ALDE. In all the ballots, inclusionary populists participated in the above-mentioned coalition, voted consistently for the proposals and were able to have them adopted. Exclusionary populists, in contrast, were able to gain a positive result only in the case of the objection to car emissions thanks to an alliance between the EPP and ENF.

Interestingly, inclusionary populists usually voted together while exclusionary populist were less cohesive. In two ballots they were split among in 
favour, against and abstained, with a slight majority voting against the three motions. They were cohesive only when they voted against the gender equality report and the refugee relocation mechanism, but they were unable to block the motions.

As already highlighted in the literature, exclusionary populists tend not to have a common ideological orientation since, albeit placeable on the right-wing side of the political spectrum, they have very different ideological backgrounds and opinions toward privatisation, liberalisation and the free market, and environmental protection. ${ }^{40}$ On economic issues, they are usually divided between liberal and socialist orientations. On environmental issues they are usually against European intervention because they perceive it as expensive, imposing unfair regulation, undermining national sovereignty, and a threat to the national economy and employment. Yet parties like Fidesz and PiS are favourable towards such a common policy.

In contrast, gender inequalities and migration represent unifying issues around which they were capable of aggregating some degree of consensus. Gender equality mobilises anti-progressive and confessional positions while anti-immigration brings together xenophobes and nationalists, all pooled together by the idea that 'different people', whether women or migrants, should be excluded.

If we look at the internal cohesion ${ }^{41}$ of European political groups, ENF and EFDD are the European political groups with more 'rebel' parties (see Table 13.12). On specific issues, MEPs voted along national lines rather than ideological ones. For instance, in the case of Right2water and gender equality, the majority of parties from Central and Eastern Europe were against a European policy. In relation to immigration, Italy (League) and Central and Eastern Europe were all against the quota mechanism.

The low rate of cohesion has an impact on the capacity of populist parties to influence ballots and, in fact, the least cohesive parties also have the lowest winning rate. Moreover, they had a low capacity to collaborate with centrist parties that influence ballots. Grand coalitions between S\&D and EPP, which decided roughly $74 \%$ of votes in the VIII legislature and EP procedures, push parties to engage in inter-group collaboration. But internal divisions and a lack of capacity to collaborate makes populists (especially exclusionary ones)

Table 13.12 Degree of cohesion and winning rate of European political groups

\begin{tabular}{lll}
\hline Political Groups & Cohesion & Winning Rate \\
\hline GUE & $86 \%$ & $50 \%$ \\
ECR & $81 \%$ & $56 \%$ \\
EFDD & $59 \%$ & $24 \%$ \\
ENF & $76 \%$ & $44 \%$ \\
\hline
\end{tabular}

Source: VoteWatch (www.votewatch.eu). 
unable to influence the adoption or rejection of dossiers through their voting behaviour.

To cope with this problem, in the IX Parliamentary term the political groups ENF and EFDD merged to create the ID group, and was also joined by parties from ECR.

To conclude, what our exploratory research tells us is that: first, there are substantial policy differences between inclusionary and exclusionary populist parties, as particularly noticed in the gender equality and immigration policy votes; second, the populist parties are not very cohesive (especially the exclusionary ones); third, the inclusionary populist parties are more capable of 'winning a deal' in terms of having decisions passed within the European Parliament. These exploratory findings are very promising, although they need to be further corroborated by future research.

In fact, further research on the current legislature (2019-2024) should be done to investigate the impact of the new political group on ballots and to assess whether exclusionary and inclusionary populists are influencing the content of legislative acts.

\section{Notes}

1 Manuela Caiani and Paolo R Graziano, 'Varieties of Populism: Insights from the Italian Case', (2016), 46, Italian Political Science Review, 2, 243-267; Manuela Caiani and Paolo Graziano, 'Understanding varieties of populism in times of crises', (2019), 42, West European Politics, 6, 1141-1158.

2 Cas Mudde, 'The Populist Zeitgeist', (2004), 39, Government and Opposition, 4, $541,543$.

3 Andrea LP Pirro and Paul Taggart, 'The Populist Politics of Euroscepticism in Times of Crisis: A Framework for Analysis', (2018), 38, Politics 3253.

4 Caiani and Graziano, 2016, (n 1).

5 Koen Abts and Stefan Rummens, 'Populism versus Democracy', (2007), 55, Political Studies, 2, 405.

6 Mattia Zulianello, 'Varieties of Populist Parties and Party Systems in Europe: From State-of-the-Art to the Application of a Novel Classification Scheme to 66 Parties in 33 Countries', (2020), 55, Government and Opposition, 2, 327.

7 Cas Mudde, Populist Radical Right Parties in Europe, (Cambridge University Press 2007).

8 Rafal Pankowski and Marcin Kormak 'Radical Nationalism in Poland: From Theory to Practice', in Ralf Melzer and Sebastian Serafin (eds), Right-Wing Extremism in Europe: Counter Strategies and Labor-Market Oriented Exit Strategies, (Friedrich Ebert Foundation 2013), 157-168.

9 Gerda Falkner and Georg Plattner, 'Populist Radical Right Parties and EU Policies: How coherent are their claims?', Robert Schuman Centre for Advanced Studies Research Paper no. RSCAS 2018/38, https://papers.ssrn.com/sol3/papers. cfm?abstract_id=3293855 accessed 8 June 2020.

10 Hanspeter Kriesi, 'Revisiting the Populist Challenge', (2018), 1, Czech Journal of Political Science, 10.

11 Mudde, (n 7), 25. 
12 Ibid., 26.

13 Ibid.

14 Caiani and Graziano 2016 and 2019, (n 1).

15 Ibid., 1144.

16 Zulianello, (n 6), 3.

17 Caiani and Graziano, (n 1).

18 Cas Mudde and Cristobal Rovira Kaltwasser, 'Exclusionary vs. Inclusionary Populism: Comparing Contemporary Europe and Latin America', (2013), 48, Government and Opposition, 2, 147.

19 Fiona Wishlade, 'The Rise of Populism, Regional Disparities and the Regional Policy Response', European Policy Research Paper, n 109, University of Strathclyde Publishing.

20 Ana Bojinović Fenko, Jure Požgan, Marko Lovec, 'Crises of the EU and the Rise of Populism and Euroscepticism in CEE', in Marko Lovec (ed), Populism and attitudes towards the EU in Central Europe, (Faculty of Social Sciences 2019), 41-70.

21 Nathalie Brack and Sharon Weinblum, 'Political Opposition, Toward a Renewed Research Agenda', (2011), 1, Interdisciplinary Political Studies, 1, 69.

22 Caiani and Graziano, 2019, (n 1).

23 Ibid.

24 Ibid., (2016), 249.

25 Ibid., (2016), 256.

26 Laurent Bernhard and Hanspeter Kriesi (2019) 'Populism in Election Times: A Comparative Analysis of 11 Countries in Western Europe', (2019), 42, West European Politics, 6, 1188.

27 Sarah L de Lange, Harmen van der Veer and Wouter van der Brug, (2017), The Radical Right in the European Parliament: Patterns of Opposition and Cooperation, EUI, http://hooghe.web.unc.edu/files/2017/04/De-Lange-Van-der-Veer-Van-derBrug-EUI-2017.pdf accessed 8 June 2020.

28 Robert K Yin, Case Study Research Design and Methods, (Sage 2009).

29 As for the populist parties, we relied on Caiani and Graziano, 2019, (n 1) and Zulianello, 2019, (n 6). We also considered popu-list.org.

30 Available at www.votewatch.eu accessed 8 June 2020.

31 James Traub, 'The EU's Next Big Election Is Heading for Disaster', (2019), Foreign Policy, https://foreignpolicy.com/2019/03/12/the-eus-next-big-election-isheading-for-disaster/ accessed 4 December 2021. Susi Dennison and Pawel Zerka, The 2019 European election: How Anti-Europeans Plan to Wreck Europe and What Can Be Done to Stop It, (European Council on Foreign Relations 2020), https:// ecfr.eu/special/the_2019_european_election/ accessed 4 December 2021.

32 Turnout, in fact, dropped to 49.51 in 1999 and to 42.61 in 2014 but rose to 50.66 in 2019.

33 Oliver Treib, 'Euroscepticism Is Here to Stay: What Cleavage Theory Can Teach Us about the 2019 European Parliament Elections', (2021), 28, Journal of European Public Policy, 2, 174.

34 Simon Otjes and Harmen van der Veer, 'The Eurozone Crisis and the European Parliament's Changing Lines of Conflict', (2016), 17, European Union Politics, $2,242$.

35 Simon Hix and Abdul Noury, 'After Enlargement: Voting Patterns in the Sixth European Parliament', (2009), 34, Legislative Studies Quarterly, 2, 159. 
36 Duncan McDonnel and Annika Werner, 'Respectable Radicals: Why Some Radical Right Parties in the European Parliament Forsake Policy Congruence', (2018), 25, Journal of European Public Policy, 5, 747.

37 de Lange, van der Veer and van der Brug, (n 27).

38 See www.votewatch.eu/blog/centre-right-eu-parliamentarians-rescuecommissions-new-proposal-on-diesel-car-emission-limits/ accessed 8 June 2020.

39 See www.votewatch.eu/blog/eu-parliamentarians-vote-in-favour-of-refugeesbinding-quotas-the-conservatives-and-the-far-right-oppose/ accessed 8 June 2020.

40 Stella Schaller and Alexander Carius, Convenient Truths: Mapping climate agendas of right-wing populist parties in Europe, (Adelphi 2019).

41 According to VoteWatch (www.votewatch.eu/blog/guide-to-votewatcheu/), 'cohesion' refers to how united a European political group is in voting situations. It is determined by the arithmetical average of the scores of the 'Agreement Index' calculated through the Hix-Noury-Roland formula: $\mathrm{Ai}=(\max (\mathrm{Y}, \mathrm{N}, \mathrm{A})-(0.5((\mathrm{Y}+$ $\mathrm{N}+\mathrm{A})-\max (\mathrm{Y}, \mathrm{N}, \mathrm{A})))) /(\mathrm{Y}+\mathrm{N}+\mathrm{A})$, where $\mathrm{Y}=$ number of votes ' $\mathrm{FOR}$ ', $\mathrm{N}=$ number of votes 'AGAINST', and A = number of 'ABSTENTIONS'. 


\title{
14 (Momentarily) drifting into ideocracy in Central Europe
}

\author{
The case of Law and Justice and Fidesz
}

\author{
Grzegorz Pożarlik
}

\section{Introduction}

I argue in what follows that the current nationalism-populism nexus in Central Europe increasingly displays features of ideocratic drift. The concept of ideocracy was recently revamped in the scholarly debate by - among others Roger Griffin, ${ }^{1}$ Uwe Backes and Steffen Keilitz, ${ }^{2}$ Jaroslaw Piekalkiewicz and Alfred Wayne Penn, ${ }^{3}$ as well as Johannes Gerschewski. ${ }^{4}$ The common denominator of the recent conceptualisations of ideocracy - as Johannes Gerschewski rightly points out - is the nineteenth century German scholarly debate on fanaticism in political systems. ${ }^{5}$ In my analysis of current ideocratic drift in Central Europe I follow the Uwe Backes and Steffen Keilitiz approach linking ideocracy with 'utopian legitimation of power'6 with specific reference to Roger Griffin's seminal: The Legitimising Role of Palingenetic Myth in Ideocracies. ${ }^{7}$ Although Griffin focused in his study on ideocracy on the analysis of the birth and evolution of interwar totalitarianism in Europe, I argue that the concept of ideocracy itself seems strikingly relevant when we wish to understand and explain the rising illiberal appetite or what Jacques Rupnik calls 'democratic backsliding'8 in Central Europe.

Thus, a major assumption of this analysis is that ideocracy, understood as an 'abuse of power in a system of political pluralism's leading to a palingenetic nomos utopia, reveals a particular relevance to the current populist turn in Central Europe. To complement the analytical matrix of this study, I refer to the very term of populism as understood along the lines of Jan-Werner Müller's conceptualisation developed in What Is Populism? ${ }^{10}$ When explaining this thesis, I explore three major rhetorical dyads of current Central European ideocratic drift, namely: the real people vs. the corrupt elite, the will of the sovereign vs. the ancien regime rule of law. I conclude by referring to the reinvention of the ethno-organic vision of the nation state as an ideological legitimation of the re-narrative of the post-1989 transformation in Central Europe. 


\section{Ideocracy in contemporary Central Europe. The concept and its explanatory power}

The illiberal revolution recently heralded by a number of populist leaders in Central Europe should not be seen as a surprise. ${ }^{11}$ After all, liberal democracy fatigue has been steadily growing for at least a decade. Frozen populist sentiments erupted on the wave of 'revolt of the masses' - using José Ortega y Gasset's ${ }^{12}$ term - against the proclaimed moral corruption of liberal elites. Fidesz in Hungary, as well as Law and Justice (Prawo i Sprawiedliwość, PiS) in Poland, have built their political reputation by appealing to the collective appetite for the will of the real people, one which should determine boundary drawing between the legitimate and the illegitimate in the public domain.

The ideology of the will of the real people as a supreme constitutional norm became the leitmotif of a re-ordering of the political system. Fundamental values of the constitutional rule of law, such as the separation of powers, have been replaced by a re-ordering of the constitutional system according to the premises of social justice as seen through the prism of an ethno-organic vision of the national community.

This illiberal revolution in Central Europe has triggered concern in the European Union and its member states, as well as in international institutions, over the condition of the democratic rule of law in Poland and Hungary. In consequence, in reaction to a number of controversial regulations introduced to the Polish and Hungarian legal systems, the European Commission and the European Parliament initiated proceedings based on Article 7 of the Treaty on European Union on the democratic rule of law and founding values. ${ }^{13}$ Also, the Court of Justice of the EU adopted a number of rulings highlighting the inconsistency between the fundamental values of the EU as stipulated in the Article 2 of the Treaty on European Union and institutional developments in the judiciary and legal systems of Poland and Hungary. ${ }^{14}$ Most recently, the European Council adopted a rule of law conditionality clause with regard to the payment of EU budget funds for 2021-2027. ${ }^{15}$

Against the backdrop of these formal developments we can find a lively scholarly debate about the essence and substance of the erosion of liberal democracy and the populist turn in Central Europe. Many have attempted to understand and explain the meaning of the constitutional U-turn in Poland and Hungary, as well as in the wider Central European region. ${ }^{16}$ In an otherwise pretty polyphonic discourse, we can discern a widespread tendency to apply analogical reasoning ${ }^{17}$ to the analysis of recent constitutional transformations.

One question seems to prevail in this debate: if the political systems in Poland and Hungary cannot be seen in terms of the fully fledged democratic rule of law, as those built on the separation of powers, what precisely are they then? In this case it is somehow natural that policy-makers and scholars tend to use - and sometimes even abuse - history to justify their claims about the nature of the new system. 
Being aware of the limitations of making a one-to-one historical analogy, I apply Roger Griffin's ideocracy as an analytical tool enabling us to understand and explain the current nationalism-populism nexus in Central Europe. I argue that consistently combining Griffin's notion of ideocracy with JanWerner Müller's conceptualisations of populist ideologies brings us closer to answering the question about the nature of the nationalism-populism nexus in a period which is bearing witness to the return of charismatic national leadership in Central Europe.

The construction that Roger Griffin built assumes the following:

a complex, dynamic, but non-dialectical and non-determinist relationship between the economic (structural) and ideological (super-structural) factors conditioning the evolution of history as well as among the social elites imposing the hegemony of certain political ideas and the subjects of an autocratic elite, who far from always being passive victims, may in some circumstances become its enthusiastic supporters and the protagonists of the historical transformation in their own right. This results in a fluctuating, irreducibly complex role played by ideology in establishing consensual legitimation, which can never be the product of the power of ideas in itself. ${ }^{18}$

The key component of Griffin's architecture is the concept of a 'palingenetic community', emerging as an outcome of a charismatic leadership proclaiming a new order inspired by the idea of national rejuvenation. ${ }^{19} \mathrm{~A}$ palingenetic community is built upon an accompanying palingenetic myth - a myth of belonging to a community of memory, morality and dignity. The palingenesis in this case means the collective affirmation of a glorious past as well as moral imperative of each true believer of the national community of the need to engage in building a new social order based on ethno-organic solidarity and charismatic leadership. Interestingly, Griffin recalls Eric Hoffer's classic study on the construction of mass movements in totalitarian societies to explain the appetite of an individual to become member of a reborn national community. Hoffer's true believer invents an individual sense of belonging to a palingenetic community:

[The true believers'] innermost craving is for a new life - a rebirth - or, failing this, a chance to acquire new elements of pride, confidence, hope, a sense of purpose and worth by identification with a holy cause. An active mass-movement offers them opportunities for both. If they join the movement as full converts they are reborn to a new life in its close-knit collective body, or if attracted as sympathizers they find elements of pride, confidence, and purpose by identifying with the efforts, achievements, and prospects of the movement. ${ }^{20}$

In order to explore the current nationalism-populism nexus in Central Europe by means of explaining the populist legitimation of ideocratic movements 
in contemporary Central Europe, we need to complement Griffin's study with Jan-Werner Müller's account of the recent populist turn. What makes Griffin's and Müller's contributions complementary is their focus on the ideological appeal of the moral exceptionalism of anti-pluralist and antielitist rhetoric heralded by contemporary charismatic populist leaders. Thus, Griffin's account of the longing for a mythical, rejuvenated national community is complemented by Müller's insight on the moral exceptionalism of 'we, and we alone represent the real people or the silent majority' rhetoric. ${ }^{21}$

Müller's conceptualisation of recent populism is deeply rooted in the belief that anti-pluralist and anti-elitist rhetoric is feeding a growing appetite in Europe as well as across the Atlantic for the de-legitimation of liberal values as the foundation of an open and democratic society and the rule of law. As Müller argues: 'Populists deny the legitimacy of all other contenders for power and also suggest that citizens who do not support them can have their status as properly belonging to the people put in doubt. ${ }^{22}$

The nationalism-populism nexus in Central Europe, as seen through the conceptual lens of Müller's theory of populism, would then be framed by a moral versus an empirical reality power struggle or 'counting versus feeling majorities' as Christoph Möllers argues. ${ }^{23}$

In the next part of this chapter I will touch upon the question of why populists are so dominant in Central Europe by diagnosing a set of two dyads: 'the real people versus a corrupted elite', 'the will of the sovereign versus the ancien régime rule of law'.

\section{Why are populists so popular in Central Europe? Ideocracy as a speech act: speaking on behalf of the real people}

The ideocratic character of the nationalism-populism nexus in Central Europe can be clearly seen through the conceptual prism of the rhetorical dyads which populist leaders have introduced into the public sphere. The nature of these dyads reveals a binary, Manichean vision of the nation, state and society. It is precisely this binary vision of politics which has appealed to many and made populism and populists so dominant.

Speaking on behalf of the 'real people' and listening to them have become key rhetorical constructs, ones which are meant to consolidate the common belief that there is just one legitimate way of understanding who constitutes the nation, who belongs properly to the national community and who is to be considered, as Jarosław Kaczyński has put it, as among the 'worst sort of Poles' who should be deprived of their truly patriotic feelings. ${ }^{24}$ Assuming the role of a speaker of the real people is essential in the overall strategy of the de-legitimisation of opponents as representatives of a somewhat 'unreal people' or 'corrupt elite'. .25

In the case of the populist leaders in Poland and Hungary, the monopolisation of speaking on behalf of the real people is meant to petrify the ideocratic model of state power. Only the leaders of the nation can properly 
address what real people want, as it is they, and they alone, who feel the pulse of the nation. Feeling the beating heart of the nation also means they have a legitimate right to stand above and move beyond any standard rules and procedures of the democratic public sphere. This in itself constitutes a radical departure from what the proponents of illiberal revolution often call ancien régime left-liberal ideology. As explained convincingly by Bojan Bugarič:

The role of the populist leader is to do what the people want. The formal structures of liberal democracy have to be put aside if they are preventing the populist leader to fulfil his role. Populist leaders distrust all the traditional institutions of liberal democracy that stand between them and the wishes of the people. As a result, many of the ECE nationalist populist parties openly flout the rule of law and explicitly reject the values of liberal democracy. A corollary of this view is the strong personalization of power, reflected in the fact that strong leaders like Orbán and Kaczyński have managed to concentrate almost unlimited political power in their hands. ${ }^{26}$

The rise of populist sentiment in Central Europe needs to be seen, however, in a much broader perspective of a steady descent into anomic society. Populist tendencies, which took the form of ideotional autocracy, did not appear out of thin air. We should have seen it coming over the course of more than 30 years of turbulent and yet unfinished democratic transformation after 1989. One of the consequences of the deep social, political and economic transformations in post-1989 Central Europe has been the petrification of a 'winners versus victims' divide that has shaped the minds of the many.

The crystallisation of the anomic structure of a traumatic society is a background for the rise of nostalgia towards a new type of l'état providence, which would even up the odds and make up for the harm that post-communist elites have done to the common people as a result of the systemic changes after 1989. Incorporating Piotr Sztompka's concept of 'trauma in social change' into the analysis of the post- 1989 social transformation reality in Central Europe is based on the enduring relevance of the concept of cultural trauma, which depicts the situation of 'sudden', 'systemic', 'new-order', 'revolutionary' transformation. ${ }^{27}$ As explained by Piotr Sztompka:

There cannot be any doubt that the collapse of communism was a traumatogenic change par excellence (...). What makes the collapse of communism a particularly interesting example of traumatogenic change is [also] that it was a 'trauma of victory' (to paraphrase Durkheim's 'anomie of success'). The change was almost universally judged as beneficial, progressive, often welcome with enthusiasm, and yet it has turned out to produce trauma, at least for some segments of post-communist societies. Finally, the traumatic sequence is in this case still uncompleted, the transformation with all that it implies is still in the making, the 
revolution is unfinished, providing fully actual laboratory for the theory of cultural trauma. ${ }^{28}$

Populists enjoy support because they have skilfully identified and addressed some of the main anxieties that have arisen. The leaders, discerning the vacuum stemming from societal anomy, have offered an ideocratic vision of an organic society based on solidarity. As is natural for any traumatic syndrome, there was insecurity, uncertainty and injustice caused by rapid change and orchestrated - as it was widely believed - by a corrupt elite and its admiration of the mechanic division of labour within the realms of a turbo-capitalist society. The antidote turned out to be the idea of an ethno-organic national community and its charismatic leadership. Indeed, l'état providence nostalgia found its resonance in the rhetoric of an indigenous Central European welfare state.

One of the sharpest examples of the rhetoric of social policy finding its own way is Viktor Orbán's National Strategy for Cooperation of 2012. ${ }^{29}$ Abandoning the past and opening up a new chapter in national history became the motto of the 'time for change' narrative. As Dorottya Szikra rightly observes, pointing to the 'failure' of the Western-style welfare state was meant to legitimise the need to build a new model welfare state. ${ }^{30}$ As Viktor Orbán himself emphasised:

All states have to accomplish the correction of the welfare state. This is more difficult in the West because they have full-fledged welfare states but not so difficult in Central Europe as welfare states are not created here. We tumble along the ruins and semi-finished buildings of post-communism, but here we have no welfare states. Our program is to establish instead of the Western-style welfare state that is not competitive, a workbased society. ${ }^{31}$

\section{The will of the sovereign vs. the ancien regime rule of law. Towards an ideocratic fundamental law system}

Replacing the ancien régime rule of law with a constitutionalisation based on the will of the sovereign, i.e. the will of the real people, is another rhetorical construct that features in the current nationalism-populism nexus in Central Europe. We, the people has lost its original connotation with the demos and has begun to denote an ethnos type of constitutional order. The ancien régime constitutional system had been identified as a major feature of so called legal 'impossibilism', which - according to Jarosław Kaczyński and the ruling United Right (Zjednoczona Prawica) coalition leaders - needs to be removed if the will of the people, meaning the will of the sovereign, is to be fully respected and made a reality. ${ }^{32}$

The flagship speech calling for turning constitutional justice into political justice was Kornel Morawiecki's parliamentary address, where he claimed 
that: 'Law is something important but it is not sacred. (...) Above the law stands the good of the Nation. If law interferes with this good, we shall not treat law as something inviolable or unchangeable. What I say is this: law shall serve us! Law that does not serve the nation is lawlessness. ${ }^{33}$

In light of such rhetoric, all those opposing the primacy of the will of the people as a fundamental law over the constitutional rule of law, including those occupying the highest positions in the judiciary, act against the will of the sovereign and are therefore considered illegitimate in their claims. As the leader of Poland's ruling Law and Justice declares: 'In a democracy, the sovereign is the people, their representative parliament and, in the Polish case, the elected president. If we are to have a democratic state of law, no state authority, including the Constitutional Tribunal, can disregard legislation'. ${ }^{34}$

In the same vein we can find Viktor Orbán and his Fidesz party re-drawing the boundary between the past and the present ideal of popular sovereignty. Robert Csehi explains this process in an insightful manner:

He [Viktor Orbán] managed to reconstruct 'the elite' from 'representatives of the past' to a 'homo sorosensus', and widened the scope of 'the people' from 'we, Hungarians' to 'we, the sovereign nations'. Similarly, Orbán renewed the conflict between the ever changing elite and 'the people', turning from economic-driven to identity politics. Finally, Orbán reinvented a toolkit of new, innovative measures that reflected a preference for greater popular sovereignty. ${ }^{35}$

Speaking on behalf of the people is also a matter of defending the will of the people when the need arises. In reaction to Article 7 TEU, launched against Hungary and Poland by a number of EU institutions, the argument about the ultimate right of the people to defend what they believe is right for them was advanced. Both Law and Justice's and Fidesz's leaders challenged the legitimate character of the concerns raised by the European Parliament and the European Commission in regard to the serious breaches of standards in the rule of law in Hungary and Poland.

Viktor Orbán, in a passionate speech given to the European Parliament in defence of the Hungarian government's position under the Article 7 proceeding, manifested a classic outsider cannot judge approach to popular sovereignty in the international system. He denied the legitimate right of the European Parliament - of which his Fidesz party is a member- to express concerns about disrespect being shown to the fundamental values upon which the European Union is built.

'I stand here now', Viktor Orbán went on to argue, 'and I see that Hungary is being arraigned by people who inherited democracy, not needing to assume any personal risk for the pursuit of freedom. [...] the report before you is an affront to the honour of Hungary and the Hungarian people. Hungary's decisions are made by the voters in parliamentary elections. 
What you are claiming is no less than saying that the Hungarian people are not sufficiently capable of being trusted to judge what is in their own interests. You think that you know the needs of the Hungarian people better than the Hungarian people themselves'. ${ }^{36}$

\section{Re-writing the corrupt past and writing the proper present and the future}

As already emphasised, after Uwe Backes and Steffen Keilitz, the utopian legitimation of power is a constitutive component of any ideocratic regime. ${ }^{37}$ In this sense, ideocratic rulers need to be - at least in declaratory terms driven by a certain ideological utopianism. ${ }^{38}$ Consequently, it may be assumed that: 'Ideocracies require existence of an ideology-based regime party, which is used for social transformation, control, monitoring, and effective combating of enemies. It also facilitates the ideologized participation of citizens in the political regime'. ${ }^{39}$

In some post-1989 Central European ideocratic narratives - Poland and Hungary especially - rewriting the history of the post-1989 change became the leitmotif of the ideology of national revival or national recovery. Thus, the ideocratic flavour of the nationalism-populism nexus in contemporary Central Europe can be felt in the reinvigoration of the rhetoric of nineteenth century national sovereignty as the background for the re-telling of the post1989 transformation in Central Europe. In the case of Poland, for that matter, the new foundation myth which has been articulated in populist rhetoric, one coined to justify the ethos of a new fourth republic, refers to the idea of national recovery, sanacja. The myth of the interwar national recovery also assumed the moral recovery of the nation and that of the state.

Perhaps unsurprisingly, analogical reasoning had been involved in the ideological legitimation of the sanacja myth as the inspiration for building the ethos of the fourth republic on the ruins of the morally corrupt regime of the third republic. The round table negotiations held in the spring of 1989 between the Communist Party leadership and the Solidarity trade union, which led the first semi-free elections to be held on 4 June 1989 and the establishment of the first non-communist government since 1945, soon began to be contested. A portion of the anti-communist opposition saw it as an illegitimate deal, a symbol of the national betrayal by the corrupt elites of the emerging third republic.

After 2015, the massive electoral victory of Law and Justice under the charismatic leadership of Jarosław Kaczyński saw the rhetoric of national moral recovery picking up momentum. The entire period of the post-1989 history of Poland became to be narrated in populist rhetoric in terms of a story of national betrayal, one deserving of moral condemnation, reckoning and punishment. The time has apparently come for a new republic based on emotional continuity with the ethos of the late second republic and the rhetoric of the moral recovery of the state - it was time for a new state, a new society and a 
new elite. All those contesting such an interpretation of Poland's post-1989 history were regarded as lacking true patriotic feeling.

Michael Bernhard and Jan Kubik explain this rhetoric in terms of a 'mnemonic' revolution - 'the new' politics of memory. ${ }^{40}$ Writing the new and true national narrative is fighting an enemy who falsifies the past in order to retain his privileges. Mnemonic actors - Bernhard and Kubik argue - challenge the ancien régime elite narrative of the post-1989 foundation myth of the republic. ${ }^{41}$ In doing so '[T]hey often treat history instrumentally in order to construct a vision of the past that they assume will generate the most effective legitimation for their efforts to gain and hold power'. ${ }^{42}$

Following Bernhard's and Kubik's terminology, we may assume that the current ideocratic drift in Central Europe is led by 'mnemonic warriors' who 'tend to espouse a single, unidirectional, mythologized vision of time [...] The alternative visions of the past - by definition "distorted" - need to be delegitimized or destroyed. The proponents of such visions need to repent or leave public life. As the holders of the truth, mnemonic warriors tend to be, therefore, proselytizers. ${ }^{93}$

The new state ideology also inspired followers of the Fidesz revolution. The new state was meant to be an illiberal national state, whilst the Western European liberal state became the significant other against which Fidesz developed its own identity. Viktor Orbán made the ultimate goal of the Fidesz revolution clear:

The new state that we are constructing in Hungary is an illiberal state, a non-liberal state. It does not reject the fundamental principles of liberalism such as freedom, and I could list a few more, but it does not make this ideology the central element of state organisation, but instead includes a different, special, national approach. ${ }^{44}$

Similarly, Law and Justice's ideology of 2015 was a revolutionary rhetoric applied to systemic change in much the same way as in Hungary after Fidesz's 2010 electoral victory. Strikingly, Jarosław Kaczyński admitted that his idée fixe is 'to have Budapest in Warsaw one day'. ${ }^{45}$ The Law and Justice leader felt inspired by Viktor Orbán's illiberal national state revolutionary vision. As rightly noted by Anna Szilágyi and András Bozóki, 'revolutionary rhetoric' had much larger connotations than just a huge electoral victory and the defeat of political opponents. ${ }^{46}$

The metaphor of revolution was further transposed into political engineering of putting an end to the liberal ancien régime and the imperative to build a new system. Viktor Orbán left no doubt that:

Today in Hungary we learned a historical lesson, that is the lesson of the past 20 years, that is the lesson of the regime change, and that is as follows: it is impossible to change a regime, a regime can be only brought down and overthrown, overthrown and replaced by a new one. ${ }^{47}$ 
An ongoing reference to historical revolutions which shaped the meaning of Hungarian identity in terms of national revival is clearly evident in the analogical reasoning ${ }^{48}$ of the post-2010 period. Again, Viktor Orban passionately recalled that:

There were several such moments in Hungarian history. In the past centuries the revolution in 1948 or the revolution in 1956 were like this, and for us the regime change in 1990 was also like this. And today, we Hungarians have arrived again at such a day. We arrive at a new one, among the rare great days of history, Hungarian history. ${ }^{49}$

\section{Concluding remarks}

The rise of the nationalistic and populist mood that we have seen in the last decade in Central Europe and the Western Balkans has been part of a much larger global trend. However, there are some similarities and clear significant differences between these trends. As Miran Lavrič and Florian Bieber notice:

There is evidence of autocratic and populist leaders across the globe, from the Philippines to the United States, gaining power in a wide range of regimes, from consolidated democracies to hybrid regimes. While it might be hard to identify a global pattern to explain the rise of such regimes, there has been a distinct democratic decline in a number of regions, including in Central and Southeastern Europe. ${ }^{50}$

Lavrič and Bieber illustrate the conceptual ambiguity and elusiveness surrounding the global democratic backsliding debate by highlighting Ronald F. Inglehart's and Pippa Norris' thesis correlating economic insecurity with a cultural backlash as providing the backdrop for a major shift in voting preferences and, above all, a major change in the value systems of contemporary societies everywhere. ${ }^{51}$ As Inglehart and Norris claim: 'the classic economic Left-Right cleavage in party competition is overlaid today by a new Cultural cleavage dividing Populists from Cosmopolitan Liberalism'. ${ }^{52}$

On the other hand, however, Florian Bieber insightfully notes that one size does not fit all. ${ }^{53}$ 'Citizens of Austria', Bieber argues, 'do not turn nationalist because their counterparts in the United States do, nor are the structural similarities so great that there is a universally fertile ground for nationalist movements from India to Kentucky. Nationalism, authoritarianism and populism are also easily conflated, while they can be mutually reinforcing they are distinct and can occur independently'. ${ }^{54}$

As argued above, the genus proximus et differentiam specificam of the Central European nationalism-populism nexus is a palingenetic imprint of ideocratic rhetoric. One of the key elements of the palingenetic myth of ideocracy is analogical reasoning, which assumes the form of an ideologically justified interpretation of the past which aims to legitimise the present. 
What seems a particularly promising direction for further research on the nationalism-populism nexus is the identification of factors determining these similarities and differences in analogical reasoning. This should encompass both the political actors engaged in this populist rhetoric as well as scholars themselves applying analogical reasoning in their research.

A case in point here is Christopher Browning's The Suffocation of Democracy. ${ }^{55}$ 'As a historian specializing in the Holocaust, Nazi Germany, and Europe in the era of the world wars', Browning concluded insightfully,

I have been repeatedly asked about the degree to which the current situation in the United States resembles the interwar period and the rise of fascism in Europe. I would note several troubling similarities and one important but equally troubling difference... . .

Studying the current ideocratic drift in Europe and elsewhere seems, therefore, an equally risky but intriguing endeavour. It certainly deserves more attention among scholars dealing with the erosion of trust in democracy and the explosion of populism and nationalism in a period of widespread societal anomy.

\section{Notes}

1 Roger Griffin, 'The Legitimizing Role of Palingenetic Myth in Ideocracies', (2012), 9, Totalitarismus und Demokratie, 39-56.

2 Uwe Backes and Steffen Keilitz (eds), Ideocracies in Comparison: Legitimation Cooptation - Repression, (Routledge 2016).

3 Jaroslaw Piekalkiewicz and Alfred Wayne Penn, Politics of Ideocracy, (State University of New York Press 1995).

4 Johannes Gerschewski, 'Do Ideocracies Constitute a Distinct Subtype of Autocratic Regimes?', in Backes and Keilitz, (n 2), 88-105.

5 Ibid., 89.

6 Backes and Keilitiz, (n 2), 2.

7 Griffin, (n 1).

8 Jacques Rupnik, 'From Democracy Fatigue to Populist Backlash', (2007), 18, Journal of Democracy, 4, 17-25; Jacques Rupnik, 'The Spectre Haunting Europe: Surging Illiberalism in the East', (2016), 27, Journal of Democracy, 4, 77-87; Jacques Rupnik, 'Explaining Eastern Europe: The Crisis of Liberalism', (2018), 29, Journal of Democracy, 3, 24-38. See also Ben Stanley, 'Backsliding Away? The Quality of Democracy in Central and Eastern Europe', (2019), 15, Journal of Contemporary European Research, 4, 343-353.

9 Griffin, (n 1), 40.

10 Jan-Werner Müller, What is Populism?, (University of Pennsylvania Press 2016).

11 Cas Mudde and Cristóbal Rovira Kaltwasser, Populism: A Very Short Introduction, (Oxford University Press 2017). See also Takis S Pappas, 'Are Populist Leaders "Charismatic"? The Evidence from Europe', (2016), 23, Constellations an International Journal of Critical and Democratic Theory, 3, 379-390. 
12 José Ortega y Gasset, The Revolt of the Masses, (W W Norton \& Company 1st edn 1932, rev edn 1994).

13 See European Parliament resolution of 16 January 2020 on ongoing hearings under Article 7(1) of the TEU regarding Poland and Hungary (2020/2513(RSP)) www.europarl.europa.eu/doceo/document/TA-9-2020-0014_EN.html accessed 28 July 2020.

14 See Court of Justice of the European Union A.K. and Others (Independence of the Disciplinary Chamber of the Supreme Court) (C 585/18, C 624/18 and C 625/18), delivered on 19 November 2019 https://curia.europa.eu/jcms/upload/docs/applicat ion/pdf/2019-11/cp190145en.pdf accessed 28 July 2020.

15 Special meeting of the European Council (17, 18, 19, 20 and 21 July 2020) Conclusions, EUCO 10/20, www.consilium.europa.eu/media/45109/210720-eucofinal-conclusions-en.pdf accessed 28 July 2020.

16 Tímea Drinóczi and Agnieszka Bień-Kacała, 'Illiberal Constitutionalism: The Case of Hungary and Poland', (2019), 20, German Law Journal, 1140-1166. See also Ireneusz Paweł Karolewski and Roland Benedikter, 'Europe's New Rogue States, Poland and Hungary: A Narrative and Its Perspectives', (2017), Chinese Political Science Review, 2, 179-200.

17 Andrew Mumford, 'Parallels, Prescience and the Past: Analogical Reasoning and Contemporary International Politics,' (2015), 52, International Politics, 1-19.

18 Griffin, (n 1), 41.

19 Ibid., 50.

20 Eric Hoffer, The True Believer. Thoughts on the Nature of Mass Movements (New York 1951), 126 cited in Griffin, (n 1), 52.

21 Müller, (n 10), 10.

22 Jan-Werner Müller, 'The Rise and Rise of Populism', 6, www.bbvaopenmind.com/ wp-content/uploads/2018/03/BBVA-OpenMind-Jan-Werner-Muller-The-Riseand-Rise-of-Populism-1.pdf accessed 12 July 2020.

23 Christoph Möllers, 'They Do What They Want, But Do They Also Know What They Want?', (2016), 17, German Law Journal Brexit Supplement, 1, 142, 1 July 2016 cited in Müller (n 22).

24 Dawid Bunikowski, 'The Constitutional Crisis in Poland, Schmittian Questions and Kaczyński's Political and Legal Philosophy', (2018), 26, Journal of Contemporary European Studies 3: Special Issue Erosion of the Rule of Law in East Central Europe, 285-307.

25 Müller, (n 10).

26 Bojan Bugarič, 'Central Europe's Descent into Autocracy: On Authoritarian Populism', Minda Da Gunzburg Center for European Studies Harvard, CES Open Forum Series 2018-2019, 4 September 2018, 15 http://aei.pitt.edu/102391/1/Work ing-Paper-Central-Europes-Descent-into-Autocracy-On-Authoritarian-Popul ism-Publication.pdf accessed 13 July 2020.

27 Piotr Sztompka, 'The Ambivalence of Social Change: Triumph or Trauma?' WZB Discussion Paper, n P 00-001, Wissenschaftszentrum Berlin für Sozialforschung (WZB) Berlin 2000, 21, www.econstor.eu/handle/10419/50259, accessed 25 July 2020 .

28 Ibid.

29 András Deák, 'Hungarian Dances - The Origins and the Future of Viktor Orbán's Revolution', (2013), 11, Lithuanian Annual Strategic Review, 1, 145-168. 
30 Dorottya Szikra, 'Ideology or Pragmatism? Interpreting Social Policy Change under the "System of National Cooperation"', in Janos Matyas Kovacs and Balazs Trencsenyi (eds), Brave New Hungary. Mapping the 'System of National Cooperation', (Lexington Books, The Rowman \& Littlefield Publishing Group 2020), 226.

31 Cited in Szikra (n 30, 226), Viktor Orbán, Speech at the 21st EPP Congress, Bucharest, Romania, 17-18 October 2012 www.fidesz.hu/hirek/2012-10-19/orbannem-joleti-allam-hanem-munka-alapu-tarsadalom-epul- kepek/ accessed 20 July 2020.

32 Marcin Matczak, 'Poland's Constitutional Crisis: Facts and interpretations', The Foundation for Law, Justice and Society in association with the Centre for SocioLegal Studies and Wolfson College, University of Oxford, Policy Brief, 5, www.fljs. org/polands-constitutional-crisis-facts-and-interpretations accessed 21 July 2020.

33 Ibid., 6.

34 Christain Davies, 'Hostile Takeover: How Law and Justice Captured Poland's Courts', Freedom House Analytical Brief May 2018 https://freedomhouse.org/rep ort/analytical-brief/2018/hostile-takeover-how-law-and-justice-captured-polandscourts accessed 10 July 2020.

35 Robert Csehi, 'Neither episodic, Nor Destined to Failure? The Endurance of Hungarian Populism after 2010', (2019), 26, Democratization, 6, 1011-1027.

36 Cited in Gábor Halmai, 'Populism, Authoritarianism and Constitutionalism', (2019), 20, German Law Journal, 300.

37 Backes and Keilitiz, (n 2), 2.

38 Ibid.

39 Ibid.

40 Michael Bernhard \& Jan Kubik (eds), Twenty Years after Communism: The Politics of Memory and Commemoration (Oxford University Press, 2014).

41 Ibid.

42 Ibid., 4.

43 Ibid., 13. See also Mateusz Mazzini, 'A Three-Dimensional Model of Enlarging the Mnemonic Conflict: The Case of Poland Under Second Law and Justice Government', (2018), 31, Slovo, 1, 45-67 as well as Ljiljana Radonić 'Our' vs. 'Inherited' Museums. PiS and Fidesz as Mnemonic Warriors', (2020), 68, Südosteuropa, 1, 44-78.

44 Cited in Gellért Rajcsányi, 'Viktor Orbán’s Hungary: Orbanist Politics and Philosophy from a Historical Perspective', 131, www.kas.de/c/document_library/ get_file/uuid=8e914238-5bca-e235-e176-f8d502f4a33f\&groupId=288143 accessed 14 July 2020.

45 Seongcheol Kim, '... Because the Homeland Cannot Be in Opposition: Analysing the Discourses of Fidesz and Law and Justice (PiS) from Opposition to Power', (2021), 37, East European Politics, 2, 11, 332-351, DOI: 10.1080/ 21599165.2020.1791094 accessed 21 July 2020.

46 Anna Szilágyi and András Bozóki, 'Playing It Again in Post-Communism: The Revolutionary Rhetoric of Viktor Orbán in Hungary', (published online 15 April 2015), 18, Advances in the History of Rhetori, Supplement, 1, 153-166. Special Issue: Rhetorics of '1989' and After: Rhetorical Archaeologies of Political Transition, DOI:10.1080/15362426.2015.1010872.

47 Ibid., 14. 
48 I refer here to Mumford's claim according to which 'Analogical reasoning as a tool of rational decision making has increasingly become replaced by analogical reasoning as a tool of trenchant ideologically informed policy justification' [emphasis added], Mumford, (n 17), 1.

49 Cited in Szilágyi and Bozóki, (n 46), 13.

50 Miran Lavrič and Florian Bieber (2020), 'Shifts in Support for Authoritarianism and Democracy in the Western Balkans' Problems of Post-Communism, DOI:10.1080/10758216.2020.1757468 accessed 17 July 2020.

51 Ibid., 4.

52 Ronald F Inglehart and Pippa Norris, 'Trump, Brexit, and the Rise of Populism: Economic Have-Nots and Cultural Backlash', August 2016 https:// research.hks.harvard.edu/publications/workingpapers/Index.aspx 3, Paper for the roundtable on Rage against the Machine: Populist Politics in the U.S., Europe and Latin America, 2 September 2016, annual meeting of the American Political Science Association, Philadelphia, 3.

53 Florian Bieber, 'Is Nationalism on the Rise? Assessing Global Trends', (2018), 17, Ethnopolitics, 5, 519-540.

54 Ibid., 519-520.

55 Christopher Browning, 'The Suffocation of Democracy', The New York Review of Books (October 2018) 25 www.nybooks.com/articles/2018/10/25/suffocation-ofdemocracy accessed 15 July 2020.

56 Ibid. 


\title{
15 A European legal war? \\ Nationalist populism, the rule of law and the language of constitutionalism
}

\author{
Przemystaw Tacik
}

\section{Introduction}

Since at least 2018, European legal studies have tended to focus on the question of a variously defined authoritarian ${ }^{1}$ (or 'neo-authoritarian') ${ }^{2}$ and illiberal ${ }^{3}$ wave that seems to undermine the legal model of liberal democracy. This 'wave', if we stick to this perhaps unfortunate hydrological metaphor, is commonly believed to have originated with the coming to power of the Hungarian Fidesz party in 2010. The re-constitution of Hungary ${ }^{4}$ and its transformation into 'an illiberal state' - in Viktor Orbán's own nomenclature ${ }^{5}$ - is presented as a harbinger of a sea-change that could soon afflict further Central and Eastern European (CEE) countries, Poland in particular, before also assaulting the strongholds of Western liberal democracies. Consequently, by means of perhaps a more apt metaphor, Hungary and Poland are treated as two patients in quarantine whose illness may easily spread to infect the very foundations of European integration. ${ }^{6}$ The festering conflict between these two countries and European institutions is easily framed in a geographical or even civilisational context, just as if it were a matter of peripheral Euroscepticism.

This perspective, although certainly not the only one in the field, ${ }^{7}$ seems to be a jurisprudential doxa that constitutes a zero-level analysis of contemporary European 'illiberalism' viewed as a threat not only to European integration, but to the framework of liberal democracy as such. Nonetheless, it is profoundly problematic due to its blind spots. First, it very easily slides back into the post-colonial and post-dependence approach that relegates illiberalism to the 'barbarian' territories of Central-Eastern and/or SouthEastern Europe and ignores the deep affinities between the CEE and Western European populist waves. In CEE, illiberalism may be in power, but the conflicts and dilemmas it stemmed from are ones which afflict the entire European Union (EU). Second, it is distorted by the 'internal ideology of the law' ${ }^{8}$ and does not recognise the complexity of the politico-ideological field in post-socialist areas, something that was thoroughly analysed in political studies in the 1990s. ${ }^{9}$ It settles for perceiving liberal democracy founded on the rule of law as an incontestable civilisational model that has only recently been called into question in CEE. Third, the delayed, unconcerted and frequently 
ineffective action taken by the $\mathrm{EU}^{10}$ and some of its member states towards CEE illiberalism epitomises the fragility of current European integration: the inability of the European institutions to act promptly and adequately may be even more worrisome than the emergence of illiberalism in these two countries.

For these reasons, the question of contemporary European illiberalism at least in the field of legal studies - should be addressed in a broader context of the fundamental dilemmas that concern the very structure of legality in the EU and particular liberal democracies. The role of peripherality (or semi-peripherality) ${ }^{11}$ in the emergence of CEE illiberalism should not be downplayed but rather related to the key tension between liberal democracy and the regimes that dismantle or reject it. The tensions between right-wing CEE populists and both the EU and the West should be rather read as a particular form of a 'European civil war' - deeply embedded in the post-Second World War and post-1989 maps of political tensions, but also recalling and rekindling interwar antagonisms - that is currently waged around the very concept of legality. If each war has a general theatre and a particular battlefield, the law may currently be perceived as the main battlefield of a general politico-economic antagonism.

This chapter will be structured in the following manner. First, I will briefly summarise the conflicts of CEE populisms with the rule of law and the European institutions defending it. Second, I will proceed to developing the concept of a 'European legal war'. Finally, I will attempt to outline the key stakes in the clash between law-based European integration and its populist right-wing opponents.

\section{Nationalist populism against the rule of law}

\section{Hybridity}

Contemporary right-wing populism in CEE shares many traits with authoritarian regimes and movements, including those of the interwar period and fascist affiliation: ${ }^{12}$ nationalism, strong leadership, xenophobia, Euroscepticism, scapegoating (including the persecution of minorities) and anti-elitism. ${ }^{13}$ These traits are manifestly not in accord with EU values as defined in Art. 2 Treaty on the European Union (TEU) ${ }^{14}$ and exemplify the attempt to build non-liberal governmentality. Nonetheless, the key to understanding the uniqueness of current CEE populism - and which simultaneously brings legality to the focal point of political struggle - is hybridity.${ }^{15}$ Both Hungary and Poland, let alone other countries of the region, are still members of the EU and the Council of Europe, as well as parties to the European Court on Human Rights (ECtHR) and other acts of European and international law that underpin liberal democracy and the rule of law.

The tension between a (now rather formal) allegiance to liberal standards and authoritarian tendencies has a few crucial consequences. First, it 
introduces certain contradictions at various levels of legality. In the case of Hungary, the 2011 constitution drafted by Fidesz and the later sub-constitutional acts may question whether it is still in accord with the ECtHR and EU law. In Poland, where the 1997 liberal constitution is still in force, sub-constitutional acts are certainly not in accordance with European law and even with the constitution itself. These contradictions make both regimes difficult to define: neither 'authoritarian' nor 'liberal-democratic' are terms good enough to match the hybridity thus created. As a result, both countries may play these labels off against each other in their mimicry of unproblematic democracies.

Second, such hybrid constructions in the field of legality eat away at legal certainty and feed clashes of norms. Whenever discordant norms remain in force, the institutions established to apply them - courts in particular are forced to decide on the hierarchy of the acts they respect. European law trumps national law according to its own autonomous principles as defined by the Court of Justice of the European Union (CJEU): ${ }^{16}$ yet both the Hungarian and Polish populist majorities have adopted national norms which are non-compliant with it. Consequently, a resolution in cases to which they apply becomes properly undecidable, as it effectively depends on the side of politico-legal antagonism that the court opts for.

Third, the hybridity of these regimes complicates one of the terms that intuitively comes to mind when the relationship between populists and the law is concerned: instrumentalisation. At first glance, it seems that what both Hungarian and Polish regimes struggle to achieve is political control over state institutions and the dismantling of legal and institutional safeguards that in liberal democracy hinder the majority from implementing any measures that it might wish. Seen from the perspective of the classic distinction that underpins the theory of the rule of law, ${ }^{17}$ current populists apparently aim to establish rule by law rather than rule of law - thereby reducing the law to the status of an instrument of power.

Yet upon closer scrutiny, the 'instrumentalisation' of the law is a problematic label. It is true that both regimes implement their own agenda by the adoption of sub-constitutional laws, sometimes in blatant disregard of European or international standards. Yet as long as the regimes remain hybrid, and the norms of EU and international law are still in force, every adopted 'instrument' entails consequences which are undesirable for the populist regimes. For example, the unconstitutional inception of the Polish National Council of the Judiciary by parliamentary majority ${ }^{18}$ and the subsequent illegal nominations of judges - now effectively dependent on the decision of the ruling coalition - were met with a reaction from the CJEU. ${ }^{19}$ In order to counteract it, the Polish populist government adopted the so-called 'muzzle law'20 that forbids courts from following the CJEU's judgment in refusing to acknowledge the legitimacy of the new judicial nominees. The muzzle law, in turn, was met with a reaction from the $\mathrm{EU}^{21}$ and will possibly be called into question by the ECtHR, to which the ruling coalition will in turn most likely react with some further instrument. This example demonstrates that even if the CEE populists 
would like to turn the law into a convenient and effective instrument of their power, the complexity of contemporary legal systems that comprise part of the EU entails an intricate map of counteractions that blunt and deform every 'legal tool' of an illiberal character.

Consequently, apart from being part of a general global cultural war, CEE populism is 'Eurosceptic' in a deeper sense. It is not simply based on anti-EU sentiments and generally does not call for Hungary and Poland to leave the Union. As a politico-juridical transformation, it develops at the heart of liberal democracy and - if we take into account the benefits of EU membership, both political and economic - would not take this form without its framework. It does not envisage constructing an authoritarian regime outside of the scope of the EU, which would be a much more coherent project than hybrid governmentality within the Union. Hungary and Poland leaving the EU has never been a seriously considered proposal. Naturally, membership-related profits provide a significant motivation, but it is the almost 50:50 imaginary division of each society into the 'liberal' and 'illiberal' camps that prevents such a move. Populist governmentality must therefore develop in a milieu which at first glance is foreign to its goals, but which it may easily feed upon.

\section{Entanglement}

The hybridity of the illiberal regimes in CEE is not a determinant pertaining to them alone. In reaction to the development of illiberalism, the EU undertook a long-lasting chain of measures aimed at curbing this authoritarian wave. These measures - only occasionally successful in particular issues, but disappointingly powerless overall ${ }^{22}$ - lead to reciprocal determination of the EU's constitutional framework by populist hybridity. In consequence, the juridicopolitical underpinning of the Union has been significantly transformed. In order to understand this entanglement in hybridity that began to draw in the $\mathrm{EU}$, its response must be analysed on two levels: 1) systemic reactions; 2) local interventions.

As to first, the initial reactions of the EU to the Hungarian populist governmentality were focused on soft measures such as political pressure, statements and communications; ${ }^{23}$ it took four years until the first targeted legal instrument was adopted, namely the EU Rule of Law Framework (henceforth RLF). ${ }^{24}$ Ironically, the RLF was presented by the EC as a tool which would more flexible and quicker to respond with than Article 7 TEU. ${ }^{25}$ This, however, was not the case. The RLF specifically targeted post-2015 Poland, ${ }^{26}$ but to little avail. For the Polish ruling majority, the dialogue with the EC was little more than a public spectacle of assurances that inaptly veiled the continuation of the previous actions. ${ }^{27}$ In 2017, soon after the major overhaul of the Polish judiciary, the European Commission decided to file a proposal to launch the first procedure defined in Article 7 TEU. ${ }^{28}$ Nonetheless, the Council to date has not decided to act on it. The only institution that proved to be deeply involved in combatting rule of law violations was the European 
Parliament, which tirelessly adopted resolutions calling for concerted action, ${ }^{29}$ including launching Article 7(1) TEU against Hungary as well. ${ }^{30}$

As of 2020, no effective systemic measures have been adopted by the EU. The Art. 7 (1) TEU procedure remains unconcluded, whereas attempts to enact a regulation that would make EU financing dependent on respect for the rule of law are far from completion. ${ }^{31}$ Apart from the EU, its 'sister organisations' the Organisation for Security and Cooperation in Europe and the Council of Europe have continuously expressed their concern; the latter promptly reacted to the Polish 'muzzle law' by adopting a resolution that opened up a monitoring procedure over Poland. ${ }^{32}$ Nonetheless, the scope of measures these two organisations may adopt is necessarily limited.

It might be rightly claimed that the general measures - especially on the part of the EU, which possesses the requisite tools to make its demands effective (Art. 7 TEU or rules of financing) - proved manifestly inadequate. The lingering 'dialogue' which has dragged on without reaching a conclusion has blunted the EU's tools. Facing difficulty in triggering general measures, the European Commission chose a path of more local interventions which consists of launching particular proceedings against populist countries before the CJEU for failing to fulfil the obligations of EU law. Especially in the Polish example, this strategy has brought some limited success.

The CJEU was able to halt - through interim measures ${ }^{33}$ - the logging of the Puszcza Białowieska, one of the last primeval forests in Europe whose heavy exploitation had been proposed by the Law and Justice (PiS) government. Even though the Polish government sought to derail the proceedings and for a certain time refused to respect the Court's ruling, ${ }^{34}$ the final result was positive overall. The CJEU played an even more important role in staving off the 'reform' that aimed to dismiss a large group of Supreme Court judges by lowering their retirement age (the President of the Republic was also given the discretion to decide which judge could continue their work). ${ }^{35}$ An analogical ruling was delivered in the case concerning judges of ordinary courts. ${ }^{36}$ The Luxembourg Court made some ambitious legal decisions in cases concerning the Polish judiciary: finding domestic judges to be judges of EU law, it applied the relevant guarantees of Art. 47 of the Charter of Fundamental Rights (CFR) to them, and set standards for judicial independence in application to the newly established Disciplinary Chamber of the Supreme Court. ${ }^{37}$ Finally, it openly gave courts of other states the competence to suspend the presumption of mutual trust in the execution of European arrest warrants (EAWs) and assess the independence of the courts in countries that undermine the rule of law. ${ }^{38}$ If the criteria of independence safeguarding the right to a fair trial under Art. $47 \mathrm{CFR}$ are not met, the domestic courts of EU states may refuse to execute a EAW.

Nonetheless, these are necessarily limited actions. They only target particular matters related to EU law and do not address the general decline of legal culture and the rule of law in Poland and Hungary. Moreover, they involve the CJEU in a nationalist smear campaign that populist governments are able 
to conduct among their domestic audiences. The success of these cases, however limited, stems from the competence of the CJEU in imposing palpable pecuniary penalties. But they do not guarantee respect for rulings: the Polish 'muzzle law' was adopted against the CJEU's judgment and, unless penalties are imposed, there are slim chances of the Polish authorities conforming to EU law in this respect.

To sum up, the ineffectiveness manifestly displayed by the EU contributes to the hybridity of populist states which, like Schrödinger's cat, are liberal and illiberal at the same time. The EU might have been rightly expected to state clearly from the very beginning where the pro-authoritarian attempts should be located vis-à-vis the liberal underpinning of European integration. Yet the EU's hesitancy ushered in an era of 'really existing populism': regimes which take a liberal affiliation and varnish it with illiberal measures and rhetoric, being at the same time tolerated as parts of the 'European legal area' ${ }^{39}$ The Union, preferring day-to-day cooperation and political interests to defending the standards of liberal democracy, effectively endorsed it, thereby calling into question the link between its own agenda and axiological self-constitution.

\section{Language of constitutionalism}

The politico-juridical hybridity of CEE populist regimes is epitomised by the transformations of their constitutional law. This dimension demonstrates the crucial stakes of the ongoing conflict between liberalism and 'illiberalism', as well as the negative character of the latter.

From the perspective of constitutional law, post-2010 Hungary and post2015 Poland differ significantly. In Hungary, the overhaul of the regime was codified at the beginning in a new constitution which, despite raising doubts as to its compliance with standards of the rule of law, ${ }^{40}$ was at least adopted by a constitutional majority by means of the prescribed procedure. In contrast, the Polish populist coalition did not gain a constitutional majority and chose a riskier path of first paralysing and then intercepting the Constitutional Court in order to freely adopt sub-constitutional laws which are not compliant with the basic law. ${ }^{41}$ As a result, the constitutionalisms of both countries represent two divergent models of populist legality: the Hungarian constitution, with its abundant amendments, ${ }^{42}$ represents a populist take on establishing its own forms of governmentality and law; and Polish constitutional law which is, in contrast, an example of an effective suspension of the constitution and its illegal substitution with ordinary laws.

It might therefore seem that the two regimes correspond to two models: of a 'successful populism' which fully expresses its agenda in the constitution and a 'half-baked populism' that must settle for makeshift measures of legal partisanry. Nonetheless, the structural incoherences within the Hungarian constitution demonstrate that both regimes are focused on their antagonism with liberal democracy, but beyond this negativity can offer little positive innovation in terms of constitutional design. In this sense, both regimes are 
half-baked populisms, unable to solidify themselves in thought-out legal forms and nurtured by a permanent fight against a more or less mythologised vision of liberal democracy.

The Hungarian constitution blends elements of the liberal democratic tradition with a strong state- and nation-centred underpinning. Consequently, although it declares respect for the rule of law (Art. B (1)), human rights protection (Art. I-XXIX), democratic election (Art. 2) and the division of powers (Art. C), it contains some manifestly anti-liberal provisions. Notably, it begins with the so-called 'National Avowal', a preamble rife with nationalist imagery that accentuates the unity of nationhood, its Christian roots, labour-based 'strength of the community' and the need of 'spiritual and intellectual renewal'. Liberal declarations about Hungary as a democratic ruleof-law republic (Art. B (1)) are mixed with enigmatic formulas of nationalist creed, like the provision which changed the official name of the country from the Republic of Hungary to Hungary ('The name of OUR COUNTRY shall be Hungary', Art. A). The inclusiveness of the Hungarian nation in respect to minorities (declared in the 'National Avowal', although with nationalistically conceived cut-and-dried differentiation between the Hungarian nation and national minorities) goes hand in hand with Article $\mathrm{D}$, which stipulates the duties of the state in respect of people of Hungarian nationality living abroad - in a manner that is reminiscent of the abuse of national minorities in the era of the League of Nations. ${ }^{43}$

As a consequence, the 2011 Hungarian constitution - instead of offering a new model of 'illiberalism' - offers nothing but a surprising mix of classic liberal constitutionalism with anti-liberal, nationalist rhetoric. Thus, the regime created is not authoritarian per se on the constitutional level; it rather accentuates non-democratic and nationalistic possibilities inscribed in the model of liberal nation-states. The Hungarian Basic Law does not invent a new 'illiberal' constitutional language. Rather, it rather breaks into three separate languages: 1) the profuse symbolic narrative replete with nation-centred clichés; 2) the liberal language of human rights, although with limitations of particular rights in line with a right-wing vision of society; and 3) pragmatic regulations of institutional functioning.

This incoherence juxtaposed with the impasse of Polish constitutionalism demonstrates that current nationalist populism in CEE does not offer a positive political project. On the contrary, at its heart it attempts to draw its legitimacy from a structural opposition to European liberal democracy.

\section{The European legal war}

The 'European civil war' is a concept with an ambiguous pedigree, one marred by attempts to downplay the responsibility of Nazis in the famous Historikerstreit. ${ }^{44}$ Yet the term in itself, which switches the perspective on European inter-state or intra-state conflicts to address their continental or global meaning, may be weaned away from its original connotations. Its great 
added value consists in how it allows us to reconstruct a more general line of conflict from an all-too-easy opposition between some CEE 'illiberal countries' and the 'liberal EU'. In this sense it allows us better to grasp the current map of antagonisms within the EU.

In a double essay which was finally made part of the Homo sacer cycle Stasis $^{45}$ - Giorgio Agamben noticed a crucial paradox: the more the contemporary world is afflicted by various forms of 'the global civil war', with terrorism being one of its symptoms, ${ }^{46}$ the less we have at our disposal a proper theory of the civil war. ${ }^{47}$ Discussing the Ancient Greek views on civil war (stasis) in its relations to polis (the city) and oikos (the family), Agamben claims:

The stasis - this is our hypothesis - takes place neither in the oikos nor in the polis, neither in the family nor in the city; rather, it constitutes a zone of indifference between the unpolitical space of the family and the political space of the city. In transgressing this threshold, the oikos is politicised; conversely, the polis is 'economised', that is, it is reduced to an oikos. This means that in the system of Greek politics civil war functions as a threshold of politicisation and depoliticisation, through which the house is exceeded in the city and the city is depoliticised in the family. ${ }^{48}$

If, following Agamben's example, we understand civil war as 'a threshold of politicisation and depoliticisation' that throws two opposites into dialectical struggle, the phenomenon of right-wing populism within the EU may be interpreted as a part of the European civil war that determines the boundaries of (de) politicisation of the law.

This perspective allows us to grasp the role of the law in the struggle between CEE populisms and 'the liberal centre' whilst avoiding the binary trap of two popular discourses. The first, which may be loosely associated with liberal jurisprudence, aims to portray the populist transformations as a somewhat barbarian onslaught on the unquestionable edifice of European legal order. ${ }^{49}$ In this discourse, populism in CEE is often presented as an effect of a peripheral 'backsliding' from otherwise unidirectional democratic development. ${ }^{50}$ Such a perspective is founded on the vision of a Kelsen-like, ultimate circumscription of the political within the boundaries of the law. As if mirroring the interwar debates between Hans Kelsen and Carl Schmitt, the second discourse accentuates the irremovability of political excess within the legal order. Seen in this light, CEE populism is interpreted as a politically motivated rejection of the supremacy of law. The frequent invocation of 'the will of the people' against 'elitist' legal institutions by populists clearly corresponds to this discourse.

In a broader perspective, these two views determine the rival camps in the European civil war. At stake is not a victory once and for all, one which will define the relations between the law and the political; on the contrary, this permanent war is precisely the threshold between the law and the political. 
There is no overarching framework to be established apart from it or 'after' it is won: the framework of relations is nothing but a moment within this war.

The reason why it is the rule of law that condenses contemporary political disputes within the EU is to be found precisely in the question of politicisation and depoliticisation. Right-wing populism today re-politicises matters hitherto shielded by the complex edifice of the European legal order, encompassing international law, European law, legal standards and requirements as to the constitutional guarantees of the rule of law. It is not an attack against the law itself, but an attempt to actively define the threshold of politicisation which circumscribes it. In this sense, the character of the populist revolt has been determined by the almost unconditional victory of the liberal understanding of the law as an overarching framework that organises the political within its boundaries.

Therefore, the law has become 'another scene' (in the Freudian-Derridean sense) ${ }^{51}$ on which the European civil war is being fought. Crucially, it is not a war of 'models' regulating relations between the law and the fact; models would just be temporary ideological tools here. It is for this reason that the 'illiberal democracies' of CEE have little that is original to offer in terms of constitutional arrangements. This war is nothing but a map of shifting goalposts that separate the legal from the political, while constitutional norms provide a bank of flagpoles erected to mark the conquered territory.

\section{Conclusions}

'Illiberalism' in the contemporary EU has undoubtedly called into question the hitherto undisputed liberal consensus. The sudden irruption of the political cast the institutions of liberal democracy and rule of law standards onto the battlefield, much to the dismay of liberal jurisprudence. From the pan-European point of view, the antagonism between right-wing populism, especially in CEE, and the liberal consensus may be explained at various levels, from economic to civilisational, yet the role that the law plays in it is symptomatic.

The conflict between Poland and Hungary, on the one side, and the EU and Western countries on the other, has been fuelled by a new version of an age-old antagonism, this time waged on the territory of the law. With an Agambenian intuition, it may be viewed as a 'European legal war': a permanent struggle to demarcate the threshold of politicisation and depoliticisation by the law. It is for this reason that CEE illiberalism not only fails to offer a coherent constitutional project, but should not be expected to do so. Its struggle is focused on shifting the boundary between the political and the legal, whereas proposing a constitutional project would re-affirm the latter. In this sense, contemporary populism is a reaction to the formalisation of the liberal political consensus in a legal form. Ominous as it may sound, the roots of the European legal war are therefore to be sought in the very form of how the EU was constructed through the law. Until a new boundary between the 
political and the legal is invented and ossifies, this stage of the European civil war will be waged chiefly on the legal battlefield.

\section{Notes}

1 Attila Ágh, 'The Eu Polycrisis and Hard Populism in East-Central Europe: From The Copenhagen Dilemma to the Juncker Paradox', (2017), 13, Politics in Central Europe, 7-32; Veronika Nagy, 'How to Silence the Lambs? Constructing Authoritarian Governance in Post-Transitional Hungary', (2017), 15, Surv \& Soc, 447-455; Daniel R Kelemen, 'Europe's Other Democratic Deficit: National Authoritarianism in Europe's Democratic Union', (2017), 52, Gov \& Opp, 211-238.

2 Maciej Gdula, Nowy autorytaryzm, (Wydawnictwo Krytyki Politycznej 2018).

3 Gábor Halmai, 'An Illiberal Constitutional System in the Middle of Europe', (2015), 14, European Yearbook of Human Rights, 497-514; Gianluigi Palombella, 'Illiberal, Democratic and Non-Arbitrary? Epicentre and Circumstances of a Rule of Law Crisis', (2018), 10, Hague Journal on the Rule of Law, 5-19.

4 On the evolution of Hungarian populist constitutionalism see: Gábor Attila Tóth (ed), Constitution for a Disunited Nation: On Hungary's 2011 Fundamental Law, (CEU Press 2012); Bojan Bugarič, 'Protecting Democracy and the Rule of Law in the European Union: The Hungarian Challenge', (2014), 79, LSE 'Europe in Question' Discussion Paper Series, 1, 7-14; Kim Lane Scheppele, 'Understanding Hungary's Constitutional Revolution' in Armin von Bogdandy and Pál Sonervend (eds), Constitutional Crisis in the European Constitutional Area. Theory, Law and Politics in Hungary and Romania, (Beck, Hart \& Nomos 2014), 111-124.

5 Csaba Tóth, 'Full text of Viktor Orbán's speech at Băile Tuşnad (Tusnádfürdő) of 26 July 2014', (2014) The Budapest Beacon https://budapestbeacon.com/full-textof-viktor-orbans-speech-at-baile-tusnad-tusnadfurdo-of-26-july-2014/ accessed 24 June 2020.

6 Laurent Pech and Kim Lane Scheppele, 'Illiberalism Within: Rule of Law Backsliding in the EU', (2017), 19, CYELS, 4.

7 Cosmin Cercel, 'The Destruction of Legal Reason: Lessons from the Past', (2019), 89, Folia Iuridica, 15-30.

8 See Lev Yavich, Obshchaya teoriya prava, (LGU 1976), 97-99.

9 Vladimir Tismăneanu, Fantasies of Salvation: Democracy, Nationalism, and Myth in Post-Communist Europe, (Princeton University Press 1996).

10 Pech and Scheppele, (n 6), 11-47.

11 See Immanuel Wallerstein, The Modern World System I. Capitalist Agriculture and the Origins of the European World-Economy in the Sixteenth Century, (University of California Press 1974), 100.

12 Cercel, (n 7).

13 Takis S Pappas, 'Populists in Power', (2019), 30, Journal of Democracy, 2, 70-74; David Prendergast, 'The Judicial Role in Protecting Democracy from Populism', (2019), 20, German Law Journal, 246-252; Andrea Pin, 'The Transnational Drivers of Populist Backlash in Europe: The Role of Courts', (2019), 20, German Law Journal, 227-230.

14 Dimitry Kochenov, 'Article 7: A Commentary on a Much Talked-about "Dead" Provision', (2019), 38, Polish Yearbook of International Law, 9.

15 Tom Gerald Daly, 'Democratic Decay: Conceptualising an Emerging Research Field', (2019), 11, Hague Journal on the Rule of Law, 22-24. 
16 Niamh Nic Shuibhne, 'What is the Autonomy of EU Law, and Why Does that Matter? (2019), 88, Nordic Journal of International Law, 9-40.

17 See Mark Tushnet, 'Rule of Law or Rule by Law?', (2014), 22, Asia Pacific Law Review, 79-92.

18 Anna Śledzińska-Simon, 'The Rise and Fall of Judicial Self-Government in Poland: On Judicial Reform Reversing Democratic Transition', (2018), 19, German Law Journal, 1839-1869.

19 Joint cases C-624/18, C-625/18 and C-585/18 EC v. Poland [2019] ECLI:EU: C:2019:982.

20 Ustawa z dnia 20 grudnia 2019 r. o zmianie ustawy-Prawo o ustroju sadów powszechnych, ustawy o Sądzie Najwyższym oraz niektórych innych ustaw, OJ 2019 at 190. See European Commission for Democracy Through Law (The Venice Commission), Poland - Urgent Joint Opinion on the amendments to the Law on organisation on the Common Courts, the Law on the Supreme Court and other Laws, Opinion no. 977/2019, (2020) www.venice.coe.int/webforms/documents/?pdf= CDL-PI(2020)002-e accessed 24 June 2020.

21 European Commission, Rule of Law: European Commission launches infringement procedure to safeguard the independence of judges in Poland https://ec.europa.eu/ commission/presscorner/detail/en/ip_20_772 accessed 24 June 2020.

22 European Commission, Reasoned Proposal in Accordance with Article 7(1) of The Treaty on European Union Regarding the Rule of Law in Poland, COM, (2017), 835 final (2018). See the European Parliament resolutions: of 13 April 2016 on the situation in Poland (2015/3031(RSP)), of 10 June 2015 on the situation in Hungary and of 3 July 2013 on the situation of fundamental rights: standards and practice in Hungary, of 16 February 2012 on the recent political developments in Hungary, of 10 March 2011 on media law in Hungary, of 13 April 2016 on the situation in Poland (2015/3031(RSP)).

23 See the speech of Vice-President Reding, EU Justice Commissioner, The EU and the Rule of Law - What next? http://europa.eu/rapied/press-release_SPEECH13-677_en.htm; http://europa.eu/rapid/press-release_SPEECH-12-596_en.htm; http://europa.eu/rapid/press-release_SPEECH-13-684_en.htm. President Barroso highlighted in his State of the Union address of September 2013, the framework 'should be based on the principle of equality between Member States and activated only in situations where there is a serious and systemic risk to the rule of law, and triggered by predefined benchmarks' http://europa.eu/rapid/press-release _SPEECH-13-684_en.htm accessed 24 June 2020.

24 European Commission, Communication from the Commission to the European Parliament and the Council: A new EU Framework to strengthen the Rule of Law, COM/2014/0158 final [2014].

25 Ibid., (n 24).

26 European Commission, Rule of law in Poland: Commission starts dialogue, 13.01.2016, WM/16/2030 http://europa.eu/rapid/press-release_WM-16-2030_ en.htm.

27 Pech and Scheppele, (n 6), 11-47.

28 European Commission, (n 22).

29 European Parliament, (n 22).

30 The European Parliament resolution on a proposal calling on the Council to determine, pursuant to Article 7(1) of the Treaty on European Union, the existence of a clear risk of a serious breach by Hungary of the values on which the Union is founded, (2017/2131(INL)) (2018). 
31 Proposal for a Regulation of the European Parliament and of the Council on the protection of the Union's budget in case of generalised deficiencies as regards the rule of law in the Member States, COM/2018/324 final - 2018/0136 (COD).

32 PACE Resolution 2316, The Functioning of Democratic Institutions in Poland, (2020).

33 Ordonnance du Vice-Président de la Cour, case C-619/18 R EC v Republic of Poland [2018] EU:C:2018:852.

34 See Przemysław Tacik, Poland's Defiance Against the CJEU in the Puszcza Białowieska Case (C-441/17) in Clara Rauchegger and Anna Wallerman (eds), The Eurosceptic Challenge: National Implementation and Interpretation of EU Law, (Hart 2019), 67-86.

35 Case C-619/18 EC v Republic of Poland [2019] ECLI:EU:C:2019:531.

36 Case C-192/18 EC v Republic of Poland [2019] ECLI:EU:C:2019:924.

37 Joint cases C-624/18 and C-625/18 A. K. and Others v Sad Najwyższy [2019] ECLI:EU:C:2019:982.

38 Case C-216/18 PPU Request for a preliminary ruling from High Court (Ireland) [2018] ECLI:EU:C:2018:586.

39 Von Bogdandy and Sonervend, (n 4).

40 Tóth, (n 4).

41 A good overview of the key developments in the Polish constitutional crisis can be found in Wojciech Sadurski, Poland's Constitutional Breakdown, (Oxford University Press 2019), 62-65; Tomasz Tadeusz Koncewicz, 'The Capture of the Polish Constitutional Tribunal and Beyond: Of institution(s), Fidelities and the Rule of Law in Flux', (2018), 43, Review of Central and East European Law, 116; Wojciech Sadurski, 'Polish Constitutional Tribunal Under PiS: From an Activist Court, to a Paralysed Tribunal, to a Governmental Enabler', (2019), 11, Hague Journal on the Rule of Law, 63-84.

42 As of 2020, the Fundamental Law of Hungary has already been amended eight times since 2011.

43 Jörg Fisch, The Right of Self-Determination of Peoples. The Domestication of an Illusion, (Cambridge University Press 2015), 159-179.

44 Ernst Nolte, Der europäische Bürgerkrieg, 1917-1945: Nationalsozialismus und Bolschewismus, (Herbig 1997).

45 Giorgio Agamben, Stasis. Civil War as a Political Paradigm (Homo Sacer II, 2), (Stanford University Press 2015).

46 Ibid., 24.

47 Ibid., 1-2.

48 Ibid., 16.

49 András Sajó, 'The Rule of Law as Legal Despotism: Concerned Remarks on the Use of "Rule of Law" in Illiberal Democracies', (2019), 11, Hague Journal on the Rule of Law, 376.

50 Gabor Hálmai, 'Transitional Constitutional Unamendability?', (2019), 21, European Journal of Law Reform, 262.

51 Jacques Derrida, 'Freud and the Scene of Writing' in Writing and Difference, (Routledge 2005), 246-291. 


\title{
16 Between patriotism and nationalism
}

\author{
National identity in the education \\ policy of Law and Justice. Comments \\ on the 2017 education reform
}

\author{
Elżbieta M. Mach
}

\section{Introduction}

In his work Education. The Treasure Within, ${ }^{1}$ Jacques Delors emphasised the importance of education for building a community within European society, as well as shaping an attitude of tolerance and cooperation which would impact the spheres of the economy, politics and culture. The European Union (EU), on the basis of subsidiarity, has transferred to member states the responsibility to determine the shape of education, its contents, and the organisation of education systems in each country, by excluding educational policy from the exclusive competence of the EU. The Treaty of Lisbon confirmed this subsidiary direction in the development of the Union's educational policy; ${ }^{2}$ simultaneously emphasising respect for the provisions of the EU Charter of Fundamental Rights. ${ }^{3}$ The Union's aim is to foster the development of the European dimension in education through the teaching and dissemination of the languages of the member states, student and teacher mobility; the mutual recognition of diplomas and periods of study ${ }^{4}$ within the renewed EU programme for higher education; ${ }^{5}$ and the adaptation of competences shaped in the educational process to the needs of society and the labour market. Education policy has undergone significant change, from primarily consisting of exchanging information on the differences between national education policies, until 2020, when, based on the Lisbon Open Method of Coordination, it began relying on the voluntary cooperation of the member states, implementing guidelines, benchmarking, and sharing good practices. Today, it has become an area of common formulation of education objectives, joint activities and co-financing of education at the international level, ${ }^{6}$ based, among others, on European programmes such as Erasmus,$+{ }^{7}$ Europe for Citizens, ${ }^{8}$ Horizon $2020,{ }^{9}$ etc. All of them implement the educational priorities of the European Union, aimed at building a common space for education and research and European civil society. In 2006, the European Parliament and the Council published recommendations on key competences ${ }^{10}$ for lifelong learning. They include social ${ }^{11}$ and civic competences. Social competences equip individuals to participate in an effective and constructive way in social and working life, 
and particularly in increasingly diverse societies. They include intercultural competences. Civic competence equips individuals to fully participate in civic life, based on knowledge of social and political concepts and structures and a commitment to active and democratic participation. They are based on knowledge of the concepts of democracy, justice, equality and citizenship, and require full respect for human rights including equality as a basis for democracy, appreciation and understanding of differences between value systems of different religious or ethnic groups. ${ }^{12}$ Civic competence is directly related to a sense of belonging to one's locality and country, as well as the EU and Europe in general, and a respect for shared values (respect for democratic principles, support for social diversity and cohesion). ${ }^{13}$ The above-mentioned legal acts do not exhaust the entire catalogue of activities under the common education policy of the EU, but they indicate the direction of the educational policies of the member states.

\section{The role of national identity in the Prawo i Sprawiedliwość programme}

In the European Parliament, Law and Justice (Prawo i Sprawiedliwość, PIS), a party considered conservative-souverainist or national-populist, advocating conservative values and the doctrine of sovereignty, belongs to the European Conservatives and Reformists Party, ${ }^{14}$ formed by conservative parties.

According to the typology introduced by Paul Taggart and Aleks Szczerbiak, ${ }^{15}$ it can be considered a 'soft Eurosceptic' party, which does not negate the EU as such and does not postulate to leave its ranks, but opposes certain elements of the Community's functioning, which places it in partial opposition to the EU. In the typology developed by Petr Kopecký and Cas Mudde, we find PIS as a conservative cadre party having moderate acceptance of EU policies and classified as a Eurosceptic party among EU-pessimist parties.${ }^{16}$ However, Krzysztof Zuba definitely considers PIS a Euro-realist party, ${ }^{17}$ that is, one that partially accepts the actions of the Union and only rejects some of its facets. In its party programme documents, Prawo i Sprawiedliwość has declared itself a Euro-realist party that does not directly deny the significance of European integration and recognises its economic usefulness; while simultaneously criticising selected elements of its policy (e.g., the European community values, ${ }^{18}$ the Bologna system in higher education); ${ }^{19}$ and suspecting the EU of nefarious plans towards Poland (an attack on Polish sovereignty and prosperity, ${ }^{20}$ a plan to eliminate Polish fisheries, a destructive policy towards Polish railways or post, climate collusion, resignation from the use of veto, the ACTA agreement). ${ }^{21}$ PIS postulated strengthening the sovereignty and integrity of nation states and expressed its opposition to EU federalism:

We do not accept the uncontrolled erosion of the sovereignty of European homelands. We will defend our freedom resolutely by introducing the 
strongest legal barriers against the possibility of such practices against Poland. This is our Euro-realism, ${ }^{22}$

as per its 2014 programme. The EU and NATO were treated instrumentally, as a tool and place to serve Polish national interests, and not as participation in a community where common goals are pursued using jointly developed mechanisms and tools. ${ }^{23}$ According to the programme of the European Conservatives and Reformists Group, ${ }^{24}$ to which PIS belongs in the European Parliament, the family is recognised as the foundation of society: 'We will effectively defend the Polish national identity, tradition, culture, and the Polish model of life and customs against the emerging transnational tendencies to conduct risky cultural experiments'. ${ }^{25}$

From the very beginning of the party's existence, the main slogans of PIS included: nation, state, Church and decommunisation, as well as God, honour and fatherland, ${ }^{26}$ but - as Paweł Śpiewak noted - 'God means the Catholic Church, honour means decommunisation, and the fatherland means the Polish nation with a strong state over and behind it'. ${ }^{27}$ The national identity of a 'true Pole' was built on the basis of the martyrdom of the Polish nation, the wartime deeds of Poles, the actions of Solidarity in 1980, the union with the native land, native tradition and Catholicism. Decommunisation was an extremely popular slogan, which assumed not only settling accounts with the history of the Polish People's Republic, but above all exposing, ridiculing and excluding political opponents by showing their ties with 'commie rule'. In order to gather supporters, PIS developed a social welfare programme which won it the loyalty of the poorest social classes. ${ }^{28}$ It also leaned on populist rhetoric (by appealing to average recipients, primitivism and radical arguments that did not take into account reality, simplifying history, searching for 'the enemy of the people', intolerance of 'otherness', ${ }^{29}$ etc.), which became a way of achieving its ideological goals. ${ }^{30}$ Martyrdom as an identifying factor became obsolete in the times of long-lasting peace, the fall of communism in 1989, and after Poland joined the European Union. ${ }^{31}$ However, after the short-term euphoria brought about by Poland's new position in the international arena after 2004, PIS, starting from 2005, began putting forward the traditional idea of Polishness constructed on the foundation of combating enemies, threats and conspiracy theories, ${ }^{32}$ strengthening national phobias (Europhobia, anti-German sentiments, homophobia, etc.) and ridiculing or deprecating other European states and nations. ${ }^{33}$ A sense of power was established by emphasising sporting successes and building the illusion of economic strength. ${ }^{34}$

The longing for the 17th-century might of the Polish-Lithuanian Commonwealth focused foreign policy activities to the east, towards Vilnius and L'viv. ${ }^{35}$ The historical and identity policy has seen the Institute of National Remembrance rise through the ranks, an office tasked with documenting the actions of the German Third Reich, the Soviet Union and the People's Republic of Poland, and prosecuting crimes against the Polish Nation. ${ }^{36}$ PIS 
has chosen to not derive the European nature of Poland from the community of values enshrined in the Treaties ${ }^{37}$ and the EU Charter of Fundamental Rights but from the presence of Christianity and - above all - the Catholic Church in public life.

To this day, the Church is the holder and proclaimer of the moral teachings commonly known throughout Poland. (...) the status of the Catholic Church in our national and public life is exceptionally important ${ }^{38}(\ldots)$. The teachings of the Catholic Church, Polish tradition, and Polish patriotism have become intertwined in building the political identity of the nation. ${ }^{39}$

The rhetoric of PIS has polarised society around two main categories of identity: ${ }^{40}$ cultural (characteristic of people with secondary and higher education, living in cities, the identification factors included: Polish language, national culture, respect for state institutions and respect for the law) and ethno-religious identity (people with a low level of education, the elderly, inhabitants of rural areas and small towns, practising Catholics, supporters of patriarchal families, with a traditional perception of the role of women in both family and professional life. The Catholic faith and Polish origin constituted determining factors. Representatives of this group 'entrusted' the fate of their country and their families to Our Lady of Częstochowa and Jesus Christ, believing in divine providence rather than in the strength of their own work and reason. ${ }^{41}$ These people preferred uncritical obedience and submission to authority, strong-arm rule; they presented authoritarian political views, respecting the influence of religious authorities on how the law is interpreted. ${ }^{42}$

One of the factors creating the national identity of Poles has been patriotic education. Patriotism is most often defined as the designation of the concept of 'nation', equated with pride, respect, love, attachment and loyalty to the homeland, common beliefs, ideals, values and norms, attitudes and their manifestations, and putting the country's interests above one's own; ${ }^{43}$ it is a sense of a social and cultural bond, the awareness of being the guardian of independence, but also work; building appropriate interpersonal bonds of ethnic groups across the entire country, community and culture in general. ${ }^{44}$ Just like identity, patriotism is a variable construct 'ranging from local, parish, and regional patriotism, through national, state, and up to civic and civilizational ones' ${ }^{45}$ It can take the form of symbolic patriotism - based on an emotional attachment to the nation; or, blind patriotism - born out of a disturbed need for security, blind and uncritical loyalty, support for the political system and xenophobic rejection of any 'others' who might pose any potential danger. ${ }^{46}$ Looking at the PIS party programme documents, one can see that everything that is not Polish (including European integration) is treated as a threat to 'true Polishness', ${ }^{47}$ and such an understanding of the concept of nation, as described by Ernest Gellner, ${ }^{48}$ that might become the 
breeding ground for the concept of nationalism was used under the guise of slogans like 'patriotism' and 'true Polish identity'. Law and Justice defines the nation as 'a community of culture, language, historical experience, political tradition, civilizational values, as a community of fate' ${ }^{49}$ The PIS programme documents quoted, as well as educational documents defining the teaching content to be used in schools, are largely in line with the belief that 'the nation is the most important form of socialisation, and national identity is the most significant element of individual identity, combined with the imperative of putting national solidarity above all other relationships and obligations, and all that is national above all that is foreign or cosmopolitan'..$^{50}$

There is a perennial dispute among social scientists as to whether nationalism should be viewed in terms of ideology, as a doctrine, a value system, or a set of socio-political measures. The ongoing discussions prove that the concept of nationalism is not one-dimensional and remains subject to modelling, undergoing an endless evolution that allows it to adapt to the 'fluid reality' of the changing conditions of how states and nations are functioning. ${ }^{51}$ In its 'soft' form, nationalism concerns the bonds between the state, territory and culture, the emotional approach to the homeland, the natural relationship of man and society with the nation; it allows consistency between autonomy, unity, collective and (national) identity, and becomes an everyday identification phenomenon for the community. ${ }^{52}$ It is defined in relation to the state of consciousness of citizens, the idea according to which the functioning of the state is organised.$^{53} \mathrm{In}$ its aggressive form, "nationalism is associated with fanaticism, hostility, hatred and chauvinism. An extreme form of nationalism is found in chauvinism, which promotes racial, national, and ethnic discrimination, an uncritical attitude towards one's own nation, exaggeration of advantages and failure to perceive vices' ${ }^{54}$ In Poland, the concept of nationalism is placed in opposition to the concept of patriotism, with a thin line running between the two. Unreflective patriotism leading to uncritical national self-love, seeing one's own nation above others or depreciating those 'others', cultivating stereotypes, mythologising the past and idealising cultural heritage, while forgetting or denying the inglorious pages of history, can give lifeblood to nationalist attitudes and become a breeding ground for nationalist groups.

\section{Patriotic education, shaping national and European identity in light of the 2017 education reform}

In 2015, the Law and Justice government launched an educational reform, modifying both the curriculum guidelines at all educational levels and the structure of the school system. ${ }^{55}$ Politicians were well aware of the fact that education policy directly influences the modelling of social awareness, and that regulating the "textbook policy's6 would provide greater control over the teaching content provided to students. In its preamble, the Law on School Education ${ }^{57}$ declares that educational aims and tasks remain in line 
with the principles set out in the Constitution of the Republic of Poland, the guidelines contained in the Universal Declaration of Human Rights, the International Covenant on Civil and Political Rights, and the Convention on the Rights of the Child. It also emphasised the importance of patriotic education and schools' role in the development of democracy, tolerance, justice and freedom. ${ }^{58}$ The executive regulation ${ }^{59}$ to the Law set out the core curriculum for all stages of education in Polish schools.

The PIS education policy is consistent with the party programme declarations of both 2014 and 2019 and the party's Euro-realist image. According to them, also in the field of education, it aims to strengthen Polish traditionalism and conservatism, and shapes national identity in opposition to European identity, building on the historical memory of national martyrdom and the Catholic faith. The understanding of 'community' is based on the nation and the family ${ }^{60}$ with the latter being given a significant role in the process of education and upbringing, recommending 'cooperation with parents, various environments, organisations and institutions considered by parents as a source of essential values, in order to create conditions facilitating the development of identity' ${ }^{6}{ }^{61}$ Such a synergy between the school, the family, and the local environment would be advisable in civil society, however, taking into account the degree of disfunction ${ }^{62}$ and civic deficits in some Polish families ${ }^{63}$ (alcohol addiction, ${ }^{64}$ drug addiction, poverty, poor general education, lack of key competences ${ }^{65}$ almost fanatical folk Catholicism, ${ }^{66}$ patriarchalism, domestic violence, ${ }^{67}$ including sexual exploitation of children in families ${ }^{68}{ }^{6 t c}$.), one may be concerned about the positive impact of such a merger on the shaping of healthy patriotic and civic attitudes and preparing the young generation to function in an open and liberal Europe.

There is also a tendency in education to strengthen the role of the Catholic Church in public and political life. Students not attending religion classes were at times discriminated against by both their peers and teachers. ${ }^{69}$ The primacy of the Catholic religion taught at school over other denominations, an uncritical attitude towards the homeland, and providing students with a ready-made model of a 'true Pole', brings to mind illustrations from an old Italian primer from the $1930 \mathrm{~s}^{70}$ and the school curricula of the same period. $^{71}$

The 2014 PIS party programme declaration promised to unify teaching contents and prevent them from diverging in the future. ${ }^{72}$ The slogan of national identity, along with shaping patriotic attitudes, is already present in preschool education, as a result of which students should feel and be able to explain their belonging to the family and nation, be in a position to name and recognise values related to social behaviour, show respect for the homeland, perform and recognise the national anthem and its other symbols, know the name of their country and its capital, and recognise symbols related to Poland's individual regions buried in tales, proverbs, legends, and fairy tales. ${ }^{73}$ Primary school, which is the foundation of education, aims to introduce students to the world of values, among which the 
following are listed: 'dedication, cooperation, solidarity, altruism, patriotism and respect for tradition, showing models of behaviour and building social relations (...) strengthening the sense of individual, cultural, national, regional, and ethnic identity. (...) the sense of national identity, attachment to national history and traditions (...) $;^{74}$ as well as appropriate patriotic and civic upbringing understood 'in a broad sense - from the language used and behaviour, to social, moral and civic obligations'.$^{75}$ These major activities of Polish education are carried out by commemorating places of national remembrance, figures and events from the past, the most important national holidays and symbols of the state, as well as places of Catholic worship. ${ }^{76}$ There would be nothing wrong with such a model of patriotic upbringing if it were not for the fact that the core curriculum omits elements of multiculturalism, which provide students with a real picture of how diverse the world is. Regional education is dominated by folklore and Polish legends, while during geography classes students learn about Polish lands, their geographical and natural aspects. Patriotic education during history classes, which is a treasury of collective memory, includes 'The history of the homeland - filled with heroism and the daily toil of ancestors, full of courage and glory, but also tragedy and doubt, and even wickedness, (...) the values shaped include: homeland, nation, state, national and state symbols, patriotism, historical memory, truth, justice, kindness, beauty, freedom, solidarity, responsibility, courage, criticism, tolerance, identity, culture' ${ }^{77}$ National identity is built based on awakening love for the homeland by attaching students to the tradition and history of their country, glorifying national achievements, strengthening the sense of national dignity and pride. Historical education is divided into two worlds (often perceived by students as incoherent) - the history of Poland and universal history, covering the course of events in the world and in Europe. However, the two historical images are not presented equally. The strong emotional factor present in patriotic education instils in pupils the image of their homeland as a martyr among nations, with the historical role of a missionary, a country invaded and torn apart by the partitioning powers; Poles who were either oppressed or heroically lost their wars and uprisings; or else they had to go into eternal exile, dreaming about freedom and sacrificing their lives for it. Those who select national heritage have not attempted any degree of historical objectivity. In Polish schools, the history of other European countries is not taught with equal emotion. Topics such as the extermination of Jews, the inglorious deeds of Poles in Jedwabne, operation 'Danube' in 1968, and the occupation of Zaolzie, ${ }^{78}$ are ignored since they disfigure the beautiful image of a true Polish patriot.

Ministerial guidelines, and thus school textbooks, do not encourage exploring one's closest environment in search of ethnic or religious diversity. Where multiculturalism is commonplace, in borderlands or regions that have been inhabited by minorities for years, local schools and communities have learned to cooperate with 'aliens' who have largely become 'their own', ${ }^{79}$ and 
it is easier to show the diversity and heterogeneity of Polish society. However, in ethnically homogenous Polish and Catholic towns (especially in villages), ${ }^{80}$ each dissimilarity is treated as a social neoplasm, which must be removed as soon as possible so that it does not grow. The mono-ethnic and mono-religious vision of the nation is also finding its way into education.

Considering that the guidelines of the Ministry of Education are addressed to all citizens and regions of Poland, one should be worried about such a one-sided educational message, consolidating or creating xenophobic, homophobic, extremely national-Catholic attitudes, far from the assumptions of liberal democracy, the ideology of equality, and the acceptance of diversity. ${ }^{81}$ Poles often uncritically accept information from authorities (and school is one of them); they have trouble thinking independently, confronting complex and diverse information, posing non-standard theses and asking questions. What is important in the context of shaping identity and anti-totalitarian attitudes is that they are unable to interpret non-obvious meanings contained in statements, understand what they read, and argue for their position..$^{82} \mathrm{It}$ can therefore be assumed that some of them thoughtlessly accept the educational message amplified outside school by messages from the public media and church pulpits, perpetuating a Polonocentric worldview and the national Catholic self-portrait of Poles.

Already in its declaration of 2014, Law and Justice policy in the area of higher education aimed at returning to the system of integrated five-year studies, in place of the current system of two-cycle undergraduate and graduate studies, thus departing from the standard set out in the Bologna Declaration. ${ }^{83}$ The European dimension in Polish education is present in a rudimentary form. It seldom appears in the school curriculum and is presented without any particular emotional or practical value. In primary school, European topics appear when discussing Christmas customs in other EU countries, International Children's Day, or the anniversary of Poland's accession to the EU. ${ }^{84}$ These activities have no impact on permanently enriching students' identity with a European dimension. In the higher grades of primary school, one might expect that history or geography lessons would provide an opportunity to introduce Europeanistic contents, but here too patriotic topics reign, with a European context nowhere to be seen:

A well-established awareness of one's own values and roots as well as territorial identity, shaped during the process of learning about the geography of one's own region and home country, is the foundation that lets us understand other nations and cultures of the contemporary world without fear of losing one's own identity. ${ }^{85}$

Such educational guidelines are fully consistent with PIS's vision of Poland in the international arena, where the history and identity policy are an extremely important dimension of foreign policy and for the existence of Poland in the world. ${ }^{86}$ 


\section{Concluding observations}

Law and Justice educational policy remains consistent with the party's political programme, with calls for reform and accompanying actions ${ }^{87}$ being systematically implemented. The administrative and organisational reconstruction of the school system's structure has been carried out, Polish schools are constantly subsidised under European education measures, and attempts have been made to strengthen the status of teachers. There are plans to create self-education platforms, expand the structures of methodological support and counselling for young teachers and to reduce school bureaucracy. These changes provide an opportunity to strengthen the role of education in shaping society and training a workforce for the Polish economy. In this regard, schools under the PIS rule largely adhere (apart from the plans to depart from the Bologna system) to the assumptions of the European Union's education policy. Indeed, the Polish education system facilitates language teaching, student mobility, adapting education to the requirements of the labour market, etc.

What is worrying is the substantive part of the reforms, which - unfortunately - is very distant from the idea of a modern, open education that trains active, liberal, tolerant European citizens, remembering their roots and simultaneously ready to live their lives in a diverse European society. By abandoning pro-equality education, actual regional education, education about minorities, shaping acceptance for 'otherness', including national identity as an element of European identity, PIS's education policy does not follow the course set out by the education changes indicated in EU documents.

Reading the guidelines of the Ministry of Education on the core curriculum for Polish schools shows that, admittedly, the document does not officially break any accepted conventions and remains in line with the law; however, it ignores the context of Europe as a common area of the life, work and social existence of Poles. It assumes the dominance of Polonocentric patriotic education, a one-sided arrangement of educational contents, creating a belief in the superiority of one's own homeland over those of other people, an endeavour to maintain the conservative and traditional status quo of social life, for example, division of social roles, family model, gender roles. School curricula do not include education on gender ideology, equal rights for nonheteronormative people and religious or ethnic minorities. The context of the socio-cultural and religious diversity - not only of Europe, but also of the environment closest to the student, their 'local homeland' - is ignored.

Shaping national identity based on the idea of conflict, seeking enemies, martyrdom and a sense of threat locks out the possibility of peaceful cooperation with other minorities and nations, blurring the thin line between patriotic education and shaping national identity, and nationalist education in the spirit of intolerance to all 'otherness' and 'strangeness'. The result is a social consent to discriminating against every 'alien' who does not fit the pattern of a 'true Pole', and to excluding those who think differently from the 'majority in power'. Poles shaped in this way do not fit into modern Europe, 
where mobility, cultural diffusion as well as the creation of international partnerships and multicultural families are commonplace and normal; where there is no need to fight for national liberation, but there is a place for mutual respect for the obligations, rights and values recognised by treaties: ${ }^{88}$ respect for human dignity, freedom, democracy, equality, the rule of law, human rights, non-discrimination, tolerance, justice, solidarity, and equality between women and men; where national identity is one of the components of human identity, and European citizenship does not conflict with national citizenship. The political and social changes taking place in Poland under the influence of Prawo i Sprawiedliwość unfortunately raise the fear that Polish education is rolling towards nationalism like a snowball, taking over more and more areas of the state and the nation's existence.

\section{Notes}

1 Jacques Delors, Edukacja jest w niej ukryty skarb. Raport dla UNESCO Międzynarodowej Komisji do spraw Edukacji dla XXI wieku, (Stowarzyszenie Oświatowców Polskich Wydawnictwa UNESCO 1998).

2 'Treaty on the Functioning of the European Union (consolidated version)', (26 October 2012) Official Journal of the European Union, C326/47, Title XII, Article 165 https://eur-lex.europa.eu/legal-content/PL/TXT/PDF/?uri=CELEX:12012E/ TXT\&from $=$ PL accessed 20 June 2020.

3 Ibid., C 326/54.

4 'The Bologna Declaration' https://web.archive.org/web/20080211212119/http:// www.bologna-bergen2005.no/Docs/00-Main_doc/990719BOLOGNA_DECL ARATION.PDF accessed 12 August 2020.

5 'Communication from the Commission to the European Parliament, the Council, the European Economic and Social Committee and the Committee of the Regions on a Renewed EU Agenda for Higher education', COM (2017), 247 final https://eur-lex.europa.eu/legal-content/PL/TXT/PDF/?uri=CELEX:52017DC0 247\&from $=$ PL accessed 20 July 2020.

6 Magdalena Górowska-Fells, Zrozumieć edukacje w Europie. 20 lat Eurydice w Polsce, (Fundacja Rozwoju Systemu Edukacij 2017), 9.

7 Erasmus + began as Erasmus 1987-1994, then as Socrates 1995-1999, Socrates II 2000-2006, Lifelong Learning Programme 2007-2013, Erasmus + 2014-2020 www.frse.org.pl/ accessed 12 August 2020.

8 Europe for Citizens Programme https://eacea.ec.europa.eu/europe-for-citizens_en accessed 12 August 2020.

9 Horizon 2020 Programme https://ec.europa.eu/programmes/horizon2020/en accessed 12 August 2020.

10 'Recommendation of the European Parliament and of the Council of 18 December 2006 on Key Competences for Lifelong Learning, OJ L, 30 December 2006', $2006 /$ 962/EC https://eur-lex.europa.eu/legal-content/PL/TXT/PDF/?uri=CELEX:320 06H0962\&from $=\mathrm{EN}$ accessed 20 July 2020.

11 Ibid., 394/17. The competence includes: the ability to communicate constructively in different environments, to show tolerance, express and understand different viewpoints, to negotiate, and to feel empathy. It is based on an attitude 
of collaboration, assertiveness and integrity. Individuals should have an interest in intercultural communication and should value diversity and respect others, and be prepared both to overcome prejudices and to compromise.

12 Ibid., (n 10), 394/16.

13 Ibid., (n 10), 394/17.

14 European Conservatives and Reformists Party https://ecrparty.eu/ accessed 12 August 2020.

15 Paul Taggart and Aleks Szczerbiak, 'The Party Politics of Euroscepticism in EU Member and Candidate States', (Opposing Europe Research Network 2002) www. researchgate.net/profile/Aleks_Szczerbiak/publication/237536121_The_ Party_ Politics_of_Euroscepticism_in_EU_Member_and_Candidate_States/links/ 5534fb440cf2df9ea6a4122f.pdf 12 August 2020.

16 Petr Kopecký and Cas Mudde, 'The Two Sides of Euroscepticism. Party Positions on European Integration in East Central Europe', (2002), 3, European Union Politics, 3, 310-316.

17 Beata Kosowska-Gąstoł, 'Euroentuzjaści versus sceptycy - Układ sił politycznych w Parlamencie Europejskim VIII Kadencji oraz powyborcze scenariusze rozwoju' in Agnieszka Nitszke and Janusz Józef Węc, Podsumowanie VIII Kadencji Parlamentu Europejskiego. Wyzwania integracji europejskiej 2014-2019, (Księgarnia Akademicka 2019), 119-138.

18 President Andrzej Duda's public statements during the 2020 election campaign, for example, aimed at taking away the right to equality from LGBT people, denying gender ideology, abandoning the principle of solidarity during the migration crisis.

19 Program PIS 2014, 137 http://pis.org.pl/dokumenty accessed 10 July 2020.

20 Adam Balcer, Piotr Buras, Grzegorz Gromadzki, Eugeniusz Smolar, W zwarciu. Polityka europejska rzadu PIS, (Fundacja in S Batorego 2017), 5.

21 Program PIS 2014, (n 19), 22-25.

22 Ibid.

23 Ibid., 150.

24 European Conservatives and Reformists Party https://ecrparty.eu/ accessed 12 August 2020.

25 Program PIS 2014, (n 19), 157.

26 These slogans constitute flagship elements of the identification of nationalist organisations.

27 Paweł Śpiewak, 'Elektorat PIS w dwa lata po wyborczej klęsce' in Marek Migalski (ed), Prawo i Sprawiedliwość, Seria wydawnicza: Polskie Partie Polityczne, (Europejskie Centrum Edukacyjne 2010), 10.

28 PIS started, among others, the following social-welfare programmes: Family 500+ , school subsidy $300+$, free medicines for seniors 75+, the Mieszkanie+ ('Home+') programme, the Maluch+ ('Toddler+') programme, the Senior+ and Senior Vigor programme, and also lowered the retirement age.

29 Tadeusz Nowak, 'Demagogia i populistyczna propaganda w przekazie publicznym polskich partii opcji narodowo-prawicowej’ in Filip Pierzchalski and Bartosz Rydliński (ed), Autorytarny populizm w XXI wieku. Krytyczna rekonstrukcja, (Friedrich-Ebert-Stiftung, Przedstawicielstwo w Polsce 2017), 147-161.

30 Andrzej Ciążela, 'Czy tylko demagogia? Intelektualne i edukacyjne konteksty sukcesów prawicowego populizmu w Europie i USA' in ibid. 33-47.

31 Program PIS 2014, (n 19), 13. 
32 In the discourse, the politicians of the ruling party, headed by its president, Jarosław Kaczyński, along with the media coverage of the state television TVP, supported by the clerical Radio Maryja cooperating with the Prawo i Sprawiedliwość party, construct an image of an anti-Polish 'enemy' and utilise hate speech to shape the understanding of Polishness and what it means to be 'a true Pole'. Not caring about European values and numerous years of peaceful cooperation within an integrated Europe, using a mythologised historical memory of Poles, they include the following, among others, in the category of enemies of the homeland: the Germans - as the invader and occupier; The European Union - as a threat to Polish identity and Catholic values; refugees and immigrants - as a source of epidemiological plague and broadly understood 'aliens'; non-heteronormative persons - as dehumanised deviants; and even the native elite - as 'smarty pants' who are the enemies of truly Polish Catholic people. The state commission investigating the Smolensk tragedy used this event to build the myth of the attempted assassination and deliberate killing of passengers of the Tupolev Tu-154 M lux plane, on 10 April 2010. For many years, this myth had become a factor that united 'true Polish Catholics' during their monthly political-prayer-propaganda meetings held at the foot of the Smolensk monument. During Andrzej Duda's 2020 re-election campaign, even the pro-ecological youth movement calling for the fight against global warming was indicated as an enemy.

33 'Poland Continues Multi-Pronged Attack on French: "We Taught Them to Use Forks"' The Guardian, (London, 13 October 2016). A reference to the famous fork scandal, where the deputy Minister of National Defence said that it was Poles who taught the French how to use forks www.theguardian.com/world/2016/oct/ 13/poland-continues-multi-pronged-attack-on-french-we-taught-them-to-useforks accessed 20 July 2020.

34 The ruling party is very careful in selecting the identification attributes emphasised in social discourse, directing the attention of the average recipient mainly towards sporting successes. The 2018 Nobel Prize for Literature awarded to Olga Tokarczuk was not widely discussed either on national television or in the social rhetoric of government circles. The success of the Polish writer was not used as a factor of self-identification promoted by the ruling party. Perhaps it is because, in her work and other activities, the author raises issues that are inconvenient for PIS: equality of rights, restriction of civil liberties, discrimination, social justice, gender issues, issues concerning non-heteronormative people, reviving nationalisms, xenophobia, as well as nature and animal rights protection.

35 Program PIS 2014, (n 19), 132.

36 Ibid., 141.

37 European Union, EU treaties https://europa.eu/european-union/law/treaties_en accessed 20 July 2020.

38 Program PIS 2014, (n 19), 11.

39 Ibid., 14.

40 Sławomir Mandes, 'Polak-katolik' in Mirosława Marody, Joanna KoniecznaSałamatin, Maja Sawicka, Sławomir Mandes, Grażyna Kacprowicz, Krzysztof Bulkowski, and Jerzy Bartkowski (eds), Spoleczeństwo na zakręcie. Zmiany postaw i wartości Polaków w latach 1990-2018, (Wydawnictwo Naukowe SHOLAR 2019), $139-152$.

41 On 16 November 2016 at the Shrine of Divine Mercy in Krakow's Lagiewniki, in the presence of bishops and priests, the President of the Republic of Poland 
Andrzej Duda, representatives of the Polish government, with the participation of the faithful, Jesus Christ was crowned as king of Poland. Cf http://introniza cja.pl/; https://wiadomosci.gazeta.pl/wiadomosci/7,114883,21000510,tlumy-naintronizacji-jezusa-na-krola-polski-uroczystosc-trwa.html; www.newsweek.pl/ polska/intronizacja-jezusa-chrystusa-na-krola-w-krakowie/2vkxmwf accessed 10 July 2020.

42 Mandes, (n 40), 145-146.

43 'Patriotyzm' https://encyklopedia.pwn.pl/haslo/patriotyzm;3955049.html accessed 10 July 2020.

44 Janusz Gajda, 'Racjonalny patriotyzm jako antidotum skrajnego nacjonalizmu' in Jerzy Nikitorowicz (ed), Patriotyzm i nacjonalizm. Ku jakiej tożsamości kulturowej?, (IMPULS 2013), 50-53.

45 Jerzy Nikitorowicz, 'Dylematy patriotyzmu, nacjonalizmu i ustawicznie kształtującej się tożsamości. Wprowadzenie do książki’ in Jerzy Nikitorowicz (ed), Patriotyzm i nacjonalizm. Ku jakiej tożsamości kulturowej?, (IMPULS 2013), 16.

46 Mirosława Czerniawska, 'Patriotyzm - jak znaleźć mu miejsce w mentalności społeczeństwa?’ in Jerzy Nikitorowicz (ed), Patriotyzm i nacjonalizm. Ku jakiej tożsamości kulturowej?, (IMPULS 2013), 76-86.

47 Program PIS 2019, 14 http://pis.org.pl/dokumenty accessed 10 July 2020.

48 Ernest Gellner, Narodyinacjonalizm,(Państwowy Instytut Wydawniczy1991), 72-74.

49 Program PIS 2019, (n 47), 12.

50 'Nacjonalizm' https://encyklopedia.pwn.pl/haslo/nacjonalizm;3945094.html accessed 10 July 2020.

51 Zygmunt Bauman, Plynna nowoczesność, (Wydawnictwo literackie 2006). A reference to the concept defined by Zygmunt Bauman as 'liquid modernity', characterised by an individual's uncertainty in the face of the permanent deconstruction of meanings, the vagueness and episodic nature of beings, and the lack of stability that gives a sense of security.

52 Andrzej Nikitorowicz, 'Nacjonalizm w warunkach demokracji' in Jerzy Nikitorowicz (ed), Patriotyzm i nacjonalizm. Ku jakiej tożsamości kulturowej?, (Impuls 2013), 87-105.

53 Marek Waldenberg, Narody zależne i mniejszości narodowe w Europie ŚrodkowoWschodniej: dzieje konfliktów i idei, (Wydawnictwo Naukowe PWN 2000), 39.

54 Nikitorowicz, (n 45), 19.

55 EACEA, 'Organisation of the Educational System and of its Structure' https:// eacea.ec.europa.eu/national-policies/eurydice/content/organisation-education-sys tem-and-its-structure-56_en accessed 28 July 2020.

56 From the school year 2014/2015, schools could use free textbooks provided by the Ministry of National Education. The textbook reform was to be completed by 1 September 2017, when free textbooks were made available for all primary and middle school grades. See also: List of MEN textbooks. https://podreczniki.men. gov.pl/ accessed 1 July 2020.

57 The Law of September 7, 1991 on School Education. Prepared on the basis of: Journal of Laws of 2015, item 2156, of 2016, item 35, 64, 195, 668, 1010, (Chancellery of the Sejm p. 1/402 of 3 October 2016).

58 Ibid., 1/402 'Education in the Republic of Poland is the common good of the entire society; it is guided by the principles contained in the Constitution of the Republic of Poland, as well as the guidelines enshrined in the Universal Declaration of Human Rights, the International Covenant on Civil and Political Rights, and the 
Convention on the Rights of the Child. Teaching and upbringing - with respect for the Christian system of values - is based on universal ethical principles. Education and upbringing serve to develop young people's sense of responsibility, love for the homeland and respect for Polish cultural heritage, while being open to the values of the cultures of Europe and the world. School should provide each student with the conditions necessary for their development, prepare them to fulfil family and civic obligations based on the principles of solidarity, democracy, tolerance, justice, and freedom'.

59 Regulation of the Minister of National Education of 14 February 2017 on the core curriculum for preschool education and the core curriculum for general education in primary schools, incl. for pupils with moderate and severe intellectual disability, and for general education in stage I sectoral vocational schools, general education in special schools preparing for employment, and general education in post-secondary schools, Journal of Laws of the Republic of Poland, Warsaw 24 February 2017, item 356.

60 Program PIS 2014, (n 19), 8.

61 Regulation of the Minister of National Education, (n 59), 3/12, 13.

62 'Family Dysfunctions. Statystyka policji' https://statystyka.policja.pl/st/wybranestatystyki/przemoc-w-rodzinie accessed 28 July 2020.

63 Małgorzata Izabela Słomczyńska, Patologie społeczne $w$ kontekście kryzysu współczesnej rodziny, e-ISSN 2392-2656, (Resocjalizacja polska no. 8/2014).

64 'Family Dysfunctions' http://parpamail.nazwa.pl/parpa_en/; https://serwisy.gazet aprawna.pl/zdrowie/artykuly/1430648,alkohol-uzaleznienie-alkoholizm-eksperci. html accessed 28 July 2020.

65 European Commission, 'Key Competences and Basic Skills' https://ec.europa. eu/education/policies/school/key-competences-and-basic-skills_en accessed 20 July 2020.

66 Adam Szostkiewicz, Dokąd zmierza polski Kościót? (Polityka 2017) www.polityka. p1/tygodnikpolityka/kraj/1708450,1,dokad-zmierza-polski-kosciol.read accessed 20 July 2020.

67 Ewa Jarosz, 'Przemoc w wychowaniu w Polsce. Obraz problemu na tle społecznej aprobaty, opinii na temat działań, oraz deklaracji rodziców', Monitoring Rzecznika Praw Dziecka, Uniwersytet Śląski 2017 www.childrenatrisk.eu/nonviolence/wp-content/uploads/sites/3/2017/12/Jarosz-wyniki-bada\%C5\%84krajowa-konsultacja-CBSS.pdf accessed 20 July 2020.

68 Ewa Jarosz and Anna Nowak, Dzieci ofiary przemocy w rodzinie. Raport Rzecznika Praw Dziecka, (Warszawa 2012).

69 Renata Kim and Anna Szulc, Edukacja w stużbie Kościoła. Szkoła religijna, (Newsweek 20/2018), 21-24.

70 Dina Bucciarelli Belardinelli, Sillabario e piccole letture, (La libreria dello Stato A X [1932]).

71 Elżbieta M Mach, Cele i treści kształcenia w związu z integracja europejska na przykładzie edukacji wczesnoszkolnej we Włoszech $i$ w Polsce, (Wydawnictwo Uniwersytetu Jagiellońskiego 2017), 87-121.

72 Program PIS 2014, (n 19), 130.

73 Regulation of the Minister of National Education, (n 59), 5-6.

74 Ibid., 11, 14.

75 Program PIS 2014, (n 19), 131.

76 Regulation of the Minister of National Education, (n 59), 15. 


\section{Elżbieta M. Mach}

77 Ibid., 22.

78 Kamil Janicki and Rafał Kuzak, '10 faktów z polskiej historii, o których wolelibyśmy nie pamiętać’ https://ciekawostkihistoryczne.pl/2014/07/28/10-wydar zen-z-polskiej-historii-o-ktorych-wolelibysmy-nie-pamietacl accessed 10 July 2020; Bronisław Tumiłowicz, 'Czego najbardziej wstydzimy się w historii Polski' www.tygodnikprzeglad.pl/czego-najbardziej-sie-wstydzimy-historii-polski/ accessed 10 July 2020.

79 Jerzy Nikitorowicz, Pogranicze, tożsamość, edukacja międzykulturowa, (Trans Humana 1995).

80 In large agglomerations the situation is somewhat different. It is easier to be anonymous there, and all kinds of diversity are part of the urban social landscape.

81 Such modelling is taking place implicitly and informally as part of the hidden curriculum, although it can be assumed that it is not happening unintentionally. From the above-mentioned analysis of the PIS programme from 2019 'The Polish Model of the Welfare State', one can get the impression that these actions are completely consistent with the vision of the ruling party.

82 Program międzynarodowej ceny umiejętności uczniów. Wyniki badania PISA 2015 w Polsce, (OCDE, IBM, MEN 2017).

83 Program PIS 2014, (n 19), 137.

84 Regulation of the Minister of National Education, (n 59), 39.

85 Ibid., 24.

86 Program PIS 2014, (n 19), 142.

87 Ibid., 2019, (n 47), 12.

88 'Consolidated versions of the Treaty on European Union and the Treaty on the Functioning of the European Union', Journal of Laws UE C326/1, 26.10.2012 https://eur-lex.europa.eu/legal-content/PL/TXT/?uri=uriserv:OJ.C_ .2012.326.01.0001.01.POL\&toc=OJ:C:2012:326:TOC accessed 20 July 2020;

EU Charter of Fundamental Rights, Journal of Laws EU 326/391, 2012/C 326/ 02 https://eur-lex.europa.eu/legal-content/PL/TXT/?uri=uriserv:OJ.C_.2012.326. 01.0391.01.POL\&toc=OJ:C:2012:326:TOC accessed 20 July 2020. 


\section{Part IV}

\section{By way of a conclusion}




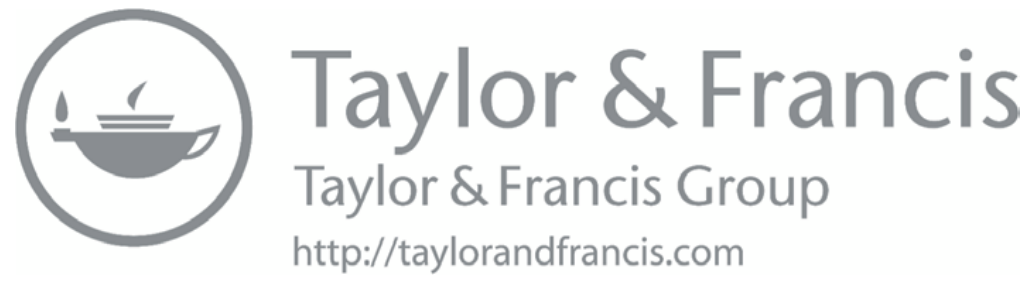




\title{
17 Pope Francis on Europe
}

\author{
Ewa Kozerska
}

\section{Introduction}

Centuries-old events, entwined with dynamic civilisational transformations on the continent of Europe, continue to be a relevant subject of numerous analyses and comments among opinion-forming circles, primarily intellectuals, journalists and representatives of public authorities. Therefore, it is only natural that this subject arouses keen interest in the Roman Catholic Church, and first and foremost in the papacy. The activity of the Bishop of Rome in this area is justified by his political sovereignty over the papal state, which has existed historically in an area of Europe. It is also undoubtedly conditioned by his spiritual and institutional guidance over Christianity, which dominates this part of the world. Pontiffs select as subjects of special reflection the events and processes that, in their opinion, have potentially major, perhaps even ground-breaking, significance for this continent. Due to the essence of their function, pastoral teachings are primarily dominated by axiological issues, but they also refer to closely related pragmatic aspects of politics, economics and ecology. Importantly, rapid geopolitical and technological changes (especially after the Second World War), which favoured a clear polarisation of the world, weakened the leading role of the Old Continent in the international order. Therefore, the multiple and inevitable global changes meant that the successors of the original pope, Peter, especially in recent decades, have begun to perceive Eurocentrism from a broader and slightly different perspective. In the tradition of the Church to date, this worldview essentially results from Western civilisation, which grew and put down roots in this part of the world and which has quite permanently penetrated certain parts of other continents (especially Latin America, from where the current pope hails). ${ }^{1}$ To a certain extent, it is also a consequence of the legitimate belief in the pioneering role of Europe in many areas, its dominance as a centre of governance and its importance as one of the main players and decision-makers on an international scale. Since the middle of the 20th century, the gradually emerging trend of increased internationalisation has induced the papacy to discern (and sometimes even initiate) the need to evenly distribute attention to all continents, whose multifaceted emancipation (among others from Europe) 
was increasingly pronounced. ${ }^{2}$ This behaviour of post-war pontiffs has undoubtedly made the Church's perspective more 'catholic' - all-embracing and signified a gradual departure from treating this European institution as an irreplaceable mentor for other regions of the world. ${ }^{3}$

These changing realities, however, have not decreased papal interest in European affairs, including during the recent momentous pontificates. John Paul II and Benedict XVI often made statements that contained reflections on what Europe is, what it will be and what it should be. ${ }^{4}$ Their official speeches on this subject indicated the need to outline the essential features constituting the Old Continent in the late 20th and early 21 st centuries. Both popes agreed that the leading element defining Europe was primarily ideological and spiritual in character. They selected this element as primary among all factors shaping the mentality, governance, production processes and international relations of this part of the world. This approach was guided by the conviction that Christian humanistic values developed in past eras constitute the basic and indispensable core of this continent. Both pontiffs noticed that this axiological and intellectual feature of the Old Continent is currently increasingly challenged by various (secular, utilitarian, religious) cultural and moral trends and ideological systems. They perceived it as a worrying symptom of the weakening of European identity, all the more so because the promotion of these often catchy ideological slogans was accompanied by social antagonisms or even forceful methods of dispute resolution. Moreover, they were aware that these social difficulties could not be addressed by formal and legal instruments used at various structural levels of the European community and in individual countries, because these tools do not guarantee the peaceful stability, unity and development of this continent. According to their predictions (especially Benedict XVI's), the modern world, in particular Europe, is regrettably suffering from extreme materialism, ethical relativism and religious fanaticism, and therefore cannot effectively combat the abovementioned problems. They attributed the main reason for this state of affairs to the lack of a common, mature spiritual and conceptual plane, which indeed set the tone for interpersonal relations and influenced international integration in the past. When the continent was still divided into the Western and Eastern blocs, John Paul II prophetically predicted that the borders of a sovereign and united Europe were determined not so much by geographical location, but by history. He emphasised that, despite historical tragedies and the experience of (even radical) ideologies, our continent could draw on the strength of unity from Christian universalism and cultural diversity, as it had done so at its dawn. In his opinion, it is primarily a 'community of spirit' built on these ideas that is able to guarantee peace and solidarity for Europe. ${ }^{5}$ The teaching of Benedict XVI followed the same approach to Europe as that of the Polish pope. Like his predecessor, he claimed that the geographical boundaries of the Old Continent have secondary and rather emblematic significance. As a result of the historical process, symbolic boundaries, often dependent on numerous internal political or cultural schisms, have been drawn in Europe alongside 
the actual ones. Nevertheless, Benedict XVI undeniably recognised that the essence of European identification goes back to the Roman Empire. Europe's historical and cultural determinants, renewed and enriched by Christianity in subsequent eras, provided a solid foundation for the civilisational, economic and political association of European peoples and states. It was Christianity that became an essential element of European self-identification, as expressed by the term christianitas denoting the western part of the continent. ${ }^{6}$

\section{Critical assessment of modern Europe}

While the position of the aforementioned bishops of Rome in the context of deliberations on the Old Continent can be considered as historically anchored in the European tradition, founded on the combination of Hellenic, Roman and Judeo-Christian thought, it is also worth looking at the insights of the current (since 13 March 2013) successor of Peter. For the first time in the history of the papacy, the head of the Roman Catholic Church is a Jesuit whose spiritual and intellectual formation, as well as his long service in the structures of the Church, were shaped outside of Europe - in Argentina. Unlike his predecessors, who came from the cultural circle of the Mediterranean Basin or Central and Eastern Europe, he is not burdened with the historical conditioning of Europeans. Despite his Italian roots, until his election as pope, he had had no opportunity to or interest in considering European problems due to the legitimate circumstance of being a priest and hierarch of the Church in Argentina. His thoughts on the subject were therefore unknown. However, due to his background, the pope's insights and comments about Europe can be inspiring, because they are formulated from the perspective of an external observer. They may therefore favour an objective and more critical diagnosis of the Old Continent, especially in terms of the prevailing ideological climate, the mental state of societies or institutional efficiency.

When he took office, Francis had to confront both the old challenges and new threats faced by Europe. Religious and social issues resulting from progressing secularism are definitely among the former. A more recent threat, one that reveals the complex interrelations of politics and economy in the wake of the financial crisis and the ensuing cultural crisis, is the threat of Europe's disintegration. As it seems, the old fractures on the continent, which may have been considered a thing of the past, have again become important factors in the destruction of European unity. ${ }^{7}$ Interestingly, these momentous challenges facing the pontificate of Francis, aptly identified by the Italian historian Aldo Giannuli, are similar to the analysis of the current condition of the Church as expressed by Jorge Bergoglio just before his election. His statements as the Primate of Argentina (repeated during his pontificate) about the Church as institution were synthetically summarised in the address at the General Congregation preceding the conclave of March 2013. Bergoglio expressed the opinion that the Church faced a serious challenge of 'coming out from itself'. By this he understood the need to depart from the attitude of 
the Church reduced to 'living in itself, of itself, for itself' in order to be more open to the 'peripheries, not only geographical, but existential'. Therefore, Jorge Bergoglio expected the Church to extend its attention to intellectual, emotional and economic problems affecting the marginalised inhabitants of the world's peripheries. This instruction was intended to commit the Church to abandoning its habit of being locked in a peculiar 'spiritual worldliness' and be more open to people in a non-institutional sense. ${ }^{8}$ Developing this thread in the exhortation of Evangelii Gaudium, he explained that the Church must not hide behind the appearance of piety or love, because it consists in seeking human glory and personal well-being instead of the Lord's glory. ${ }^{9}$ This warning was also intended to remind the Church of the need to follow one of its primary principles, Ecclesia semper reformanda, according to which the institution ought to adapt to the expectations of the era without changing its dogma. ${ }^{10}$ In the words of the then Primate of Argentina, this necessary renewal will allow the evangelical Church to become 'the fruitful mother who lives from 'the sweet and comforting joy of evangelising'. ${ }^{11}$ The identification of the Church with the mother figure, highlighted in the address above and typical of Catholic theology, especially in the 20th century, emphasises that, apart from the metaphysical dimension, it also has a fundamental human aspect. It seems that the use of such a simile endows the Church with causative abilities to survive and develop, which are important from the perspective of human (especially female) nature, because they trigger the instinct for caring for everyone, without exception.

This meaningful pastoral message of J. Bergoglio, identifying significant problems faced by the seemingly 'lost' Church and calling for its renewal, was also applied to the institutions and inhabitants of Europe. During the relatively short period of his service as pope, Francis has shown that he is keenly interested in the current historical moment of the Old Continent, recognising the threats as well as present and future challenges facing this part of the globe. Francis's position in this respect was revealed primarily in his speeches to the European Parliament. Accepting official invitations issued by this important institution of the European Union, he used the opportunity to revisit the ideological assumptions that guided the founding fathers of a united Europe after the tragic experience of war. ${ }^{12}$ At the same time, he noticed that the passage of time, marked by cultural, ideological, geopolitical, economic and technological changes, had also revealed the existence of disturbing tendencies in this community, which may lead to the revision and even negation of these noble, once universal values on which the peaceful and solid coexistence of West European countries was founded. In the much-quoted speech of 25 November 2014, during his first visit to the European Parliament, he even said that Europe on the whole gives an impression of ineptness in solving numerous cultural, ideological and existential difficulties. What is more, in the face of dynamic civilisational challenges, Europe shows procedural failures that neither individual countries nor supranational organisations are able to overcome. These phenomena were not stopped by the process of expanding 
the borders of the European Union, which was intended to strengthen the position and scope of influence of this continent. Similarly, the advancement of globalisation has not only undermined historically well-established Eurocentrism, but has become another factor causing the withdrawal of this important region from the position of a world protagonist. In light of the above, it is not surprising for the pope that the coincidence of these conditions leads to a suspicious and distrustful approach to Europe by external actors. What is more disturbing is that Europe is losing its great ideals that once stimulated its enthusiasm for creativity, drove integration, mobilised societies to seek alternative solutions in various spheres of being, and attracted other continents due to their dynamism. Today's Europe seems to be tired and in decline. Satisfied with the achieved status quo, it does not see the need to search for new solutions to the current difficulties. In Francis's opinion, this continent appears to give 'a general impression of weariness and aging', like 'a grandmother who is no longer fertile and vibrant'. ${ }^{13}$ Although this rather colloquial-sounding statement, typical of this pontificate, did evoke lively comments, it resulted in neither serious political debate nor deepened intellectual inquiry. Undoubtedly, by sharing this reflection, the current successor of Peter felt obliged to mobilise Europe to face what he perceives as severe civilisational challenges for the continent. Overcoming them in this important part of the world should become a priority in order to restore the proper internal vitality and unity, and the proper international position of the cradle of Western civilisation.

Much like his predecessors, Francis perceives the essence of Europe's unsatisfactory performance also in structural terms, primarily in the deficiency or superficiality of the ideological and spiritual plane. A particularly severe drawback in this respect is the widespread promotion of incorrectly understood anthropology. He clearly emphasises that the contemporary approach to the individual and his rights lead to the absolutisation of man and deprives him of the actual biological, cultural and social determinants. Adopting this approach unfortunately results in the affirmation of the subjective rights of individuals accompanied by indifference to the rights of other individuals and relinquishing obligations to them. This is conducive to a lifestyle based on the promotion of egoistic and wasteful consumerism, which is commonly accompanied by the so-called culture of rejection. This attitude clearly influences the breakdown of social bonds (family, professional, local, national, supranational), the arbitrary exclusion of certain categories of people (homeless, lonely, elderly, helpless, immigrants and refugees) from public life, and finally leads to denying the most vulnerable beings (unborn children, the bedridden) the right to exist. According to the Pope, this peculiar egocentrism, coupled with a lack of social sensitivity, is a manifestation of ideological emptiness (which characterises the 'Western' world) that is becoming one of the most important civilisational problems faced by modern Europe. ${ }^{14}$ It is all the more worrying for him because this shallow and uncertain ground favours extremist attitudes. Moreover, it is increasingly conducive to violence, hatred and social 
conflicts rooted in cultural, moral, ideological, religious or ethnic issues. The pope notices another significant imperfection of this continent in the systemic organisation and functioning of Europe's governing institutions at the national and supranational level. The excessive bureaucracy and structural formalism that characterise them translate into practical difficulties in ensuring public security and meeting the existential needs of societies; they also paralyse praiseworthy bottom-up initiatives. Francis is convinced that the promotion of the aforementioned superficial culture of life in combination with excessive functionalism of administrative structures destroy Europe's mental and material achievements. These factors lead to the loss of momentum in reunification efforts and allow the technocratic paradigm to rule. ${ }^{15}$ This pessimistic evaluation of modern Europe, similar to the diagnosis of the Church, expressed the pope's concerns about their future. By using the rather original comparison to the poor condition of the 'spirit and body' of an older woman, Francis clearly wanted to stress Europe's structural weakness, intellectual crisis and loss of vitality. As in the case of the Church, his suggestive reference to feminine nature was intended to emphasise the uniqueness of the female sex, but first and foremost to highlight women's indisputably crucial role in the gift of life, continuity of existence and possibility of development, as well as their ability to care for and protect everyone in need. ${ }^{16}$ In the context of Francis's teaching, this symbolic reference to the woman - mother and grandmother, with her instinctive, emotional and cultural predispositions indicating the primacy of man's relational attitude - functions as a reminder about the foundations of civilisation, also in Europe. He is convinced that rejecting this heritage in the long run will not be conducive to the expected dignified existence or harmonious development of both human society and spiritual community as well as political organisation.

\section{Prospects for the renewal of the European community}

Thus, by drawing a positive picture of the future of Europe, the pope encourages the restoration of the noble ideals of the founding fathers of the European Union. Respectful to the boldly conceived idea of the unification project, he stresses that it was underlain by the need to build a community fundamentally based on the Christian concept of the person. The essence of this idea was the recognition of 'transcendent dignity' in man as the foundation for the unity of Europeans and the functioning of their political and legal structures. As was the case with the initiators of the unification of Europe, Francis selected this aspect as the main thread in his reflection on the real potential of Europe and the need to return to what its spiritual unity is based upon. His reference to human dignity derived from God was also meant to emphasise the moral aspect of human nature. These determinants justify the essence of inherent and inalienable rights, which are vested in every human being without exception. As the pope emphasised, these individual attributes of man simultaneously confirm his relational nature and the ability to create a 
real social community. It is the ethical and social features inscribed in human nature that allow individuals to responsibly make free and wise choices for the benefit of solidarity and interdependent human relations. Francis reminded his audience that this aspect of Christian heritage, which accounts for both key dimensions of human nature (transcendent dignity and relativity), undeniably contributed to the formation of European humanism and the development of civilisation. ${ }^{17}$ This unique spiritual unity is identified by the pope with an intellectual formation that causes some people to belong to each other, "that each of our lives is anchored in the lives of others', ${ }^{18}$ that we are not lone nomads and that human life makes sense first and foremost within a spiritual community. Moreover, he emphasised that the essence of true spirituality lies in God as all-powerful and Creator. If we deprive it of this source, we will end up worshipping other earthly powers (gods of power, money, possession) or usurp the place of God. ${ }^{19}$ Therefore, by emphasising the indisputable importance of this achievement of European civilisation, the pope shows his conviction that it should continue to function as an absolute signpost for the benefit of future generations. He believes that openness to the Christian concept of anthropology will provide Europe in the future with a harmonious combination of the now weakened spiritual element with institutional pragmatism. The correlation of these two planes will determine whether Europe will be teeming with life and developing, or whether it will become increasingly stagnant and forgotten. He simultaneously emphasises that the modern, secular (of Enlightenment origin) Europe will not lose its identity if it returns to a form of humanism which is rooted in Christianity. On the contrary, it can be enriched with values that will help it overcome the numerous social tensions or the aggressive, externalist attitudes of certain environments. Contrary to the proclamations of certain opinion-forming circles or secular institutions, he asserts that the return to the Christian element of humanism should not raise unjustified fears about the Church's inclinations to impose religious integrity or eliminate ideological freedom. It should be remembered that modern European and national institutions in practice refer to shared (often Christian) ideals, such as the principle of the common good, subsidiarity, solidarity, justice, peace and a humanism centred on respect for the dignity of the human person. ${ }^{20}$

Just as the secular world expects heterogeneity from the Church, the pope also expects the world to interpret the motto of the European Union - 'unity in diversity' - in the spirit of the abovementioned common values. ${ }^{21}$ In this context, he warned European institutions not to succumb to the harmful centralistic manner of harmonising the various (intellectual, cultural, political or economic) levels of life of Europeans. Such uniformity destroys the blessing of diversity, favouring the promotion of a new incarnation of political nominalism, which is incompatible with the spirit of democracy. It also serves the universal dictate of relativism, 'anti-historic fundamentalisms' and an ethics devoid of life's wisdom. It shows dangerous tendencies to reduce the wealth of private and public life views to the sphere of ideas, 'words, images, 


\section{Ewa Kozerska}

sophistry'. In this way, European institutions impose a form of governance that is imaginary and detached from real and often complex problems, giving the impression of a flattened, one-dimensional reality. As a consequence, the pope noted, the cognitive condition of societies is impoverished and it is exposed to the 'ideological colonisation' visible in Europe. ${ }^{22}$ From the perspective of space and time, such colonisation generates deepened ideological divisions, which often take the form of terrorism. Thus, Francis clearly warns against succumbing to the pressure of the incomprehensible tension between ideas and realities, which he understands as the dissonance between the spiritual and intellectual sphere in Europe, which is already devoid of content or even in atrophy, and the excessive adherence to uniformity tinged with functionalism and pragmatism. In his opinion, for the good of Europe, there must be a dialogue between these categories that would allow 'the idea to capture, understand and direct reality'. ${ }^{23}$ To explain this non-innovative discourse on the correlation between thought and reality, which already troubled ancient philosophers, the pope used the readily recognisable painting The School of Athens. It was not the first time in his pontificate that he had referred to this fresco by Rafael Santi. The way he sees it, the painting symbolically presents the relation between the idea, associated by the pope with the supernatural world, and the concrete world, which reflects the crux of European history. The content of this artistic work, he emphasised, should remind the contemporaries of the truth that the idea (heaven) is to illustrate openness to the transcendent God, which is not foreign to Europeans, and temporality (earth) - a practical ability to manage various complex existential situations. ${ }^{24}$ In the pope's opinion, this truth cannot be manipulated. Misinterpretations of this emblematic message, for which both secular and religious leaders are responsible, have spread the impression that these categories of thought are polar opposites. This cognitive misunderstanding has not only resulted in a disastrous separation of the spiritual and ideological sphere from politics, but also led to an incorrect reduction of these concepts to lapidary rhetoric or unreal intellectualism. In his opinion, this disturbing focus on the plane of pure ideas, detached from reality, as Plato did, is dangerous. It threatens to establish a susceptibility to harmful Gnostic views in European institutions, such as the Church, ones which focus only on the subjective logic of thinking and one's own experiences. ${ }^{25}$ As the pope emphasised, such a faulty isolated pseudoscientific mentality ought to be questioned. This attitude will prevent the building of a future that is deeply rooted in a true humanistic heritage and prevent the verification of the defects of the present time. He argues that opening to the Christian tradition of humanism will contribute to overcoming this incomprehensible tension between thought and fact and will creatively affect the indispensable relationship between religion and society (and politics). He is convinced that just as reason and faith, so too religion and people (and their institutions) are able to properly enlighten and support each other. In a situation where both sides succumb to fanatical extremes, it will help to 'cleanse' them of ideological extremisms that only generate destructive 
aggression and violence. ${ }^{26}$ The future of Europe, like its glorious past, is therefore dependent on the rediscovery of the inseparable link between the idea (with Christian spiritual and intellectual roots) and reality (a multidimensional real existence).

In Francis's opinion, putting these relations in order will allow modern Europe to return to the correct formula of the unity of the community the family of European nations. He rightly noted that it is expressed in the freedom of each member state to cultivate its own local identity and support grassroots, creative citizenship. The motto of the EU should not be an empty phrase, but actually oblige the European community to adopt the attitude of a protagonist of the values of individual national historical traditions. At the same time, this creed should contain any tendencies to succumb to unjustifiable prejudices or cultural phobias and intellectual manipulations. In the belief of the Bishop of Rome, it is the ability to combine the idea of unity with various regional particularisms that can promote the authenticity desired by the European community and by individual democratic states, favouring political pluralism. ${ }^{27}$ That is why Europe must confront its problems by means of the so-called polarity and transversality. He noted that the history of modern Europe can no longer be geopolitically reduced to a bi- or tri-polar structure in which decision-making in common matters is reserved for a narrow and intrinsic elite. This concept is currently undergoing a global experiment in multipolarity that is both connective and disintegratory in terms of culture (not necessarily overlapping with specific state borders), ethnicity, language, politics or religion. This challenge is connected with the search for constructive harmony, but also with the danger of delusionary yielding to a pragmatic hegemony that destroys authentic cultures and religions of nations. Building the multipolarity of European internal relations and tensions requires the recognition and preservation of the unique features of each nation. The consolidation of the continent also requires transversality, which the pope understands as intergenerational dialogue, and even a cross-sectional exchange of opinions. This is dependent on empathy between generations, embracing the historical method of development by exchanging thoughts with representatives of other religious, political, or cultural identities. Francis is convinced that the aforementioned spirit of openness, characteristic of youthful mentality, will allow Europe to make progress towards a peace that is fraternal and free, acquire skills to bridge divisions and build mutual respect on genuine tolerance. ${ }^{28}$

This typically European 'unity in diversity' was also considered by the pope from the perspective of tensions between the whole - the European community - and its parts - the individual nations. On the one hand, that which is local, original, rooted in and committed to the history of one's own place, favours personal and state development, which is an added value. However, the adoption of this attitude by individuals, social groups or countries may also create the danger of building a 'folkloristic museum of local hermits', isolated and deprived of the ability to respond to differences, which may 
lead to the sterility of such a community. On the other hand, in the spirit of the Aristotelians, the pope remarked that the whole is greater than the sum of its parts and that one should not tightly cling only to local and minor matters. One must first and foremost keep in mind the greater good that benefits everyone, not just a few. However, such a broader European perspective should not condemn nations and individuals to global universalism, in which citizens adopt a conformist attitude and are subject to uprooting. The pope acknowledged that the European community should harmoniously cooperate with individual countries so that neither side falls into these extreme behaviours. This ability to interact should therefore consist of combining the positive aspects of the unique identities of smaller communities or states with their commitment to the benefit of a larger (whole) community, from which they receive in return new stimuli for development. ${ }^{29}$ The real unity and integrity of peoples lies in the fact that they maintain their identity in a universal order. What is more, these values are co-created by the general public seeking true common good which does not exclude anyone from creating and using bonum commune. In this context, Francis warned against public use (especially by politicians or the media) of intellectual confusion to justify new forms of discrimination, authoritarian tendencies or short-sighted aggressive behaviour of ethnic groups or religious fundamentalists, which can only generate violence ${ }^{30}$ Religious, political and ethnic pluralism means respect even for different values and their adherents, which excludes the privatisation of ideas, religion, culture or politics with the intention of muting them or confining them to their own institutional limits. According to the pope, it is also important to return to a good tradition (identified with a new form of 'agora'), enabling the free exchange of opinions by secular and religious institutions that mutually respect each other's autonomy. In his opinion, a reference to pluralistic discourse will enable a broader view in search of the true common good. He warned that imposing a unified cultural, religious or political concept while eliminating the richness of these traditions eliminates tolerance and peace in the long run. It deepens resentment and contributes to the breakup of the common plane of existence. ${ }^{31}$

The renewal of the European community formula as proposed by Francis requires the affirmation of every human rooted in Christian humanism in the currently favourable conditions of lawful democracy. He advises the European community to pay special attention to fundamental human rights, which are treated as the undisputed foundation of states, supranational organisations, and the civilisational heritage of this continent. Among them, he singles out the rights of the basic social cell - the family. Due its procreative skills, this natural community ensures generational continuity, but also teaches social bonds and builds a home that consolidates the past with future generations. The family also plays an important role in the intellectual, technical (including ecological) and spiritual formation of man. It undeniably influences the individual discovery of one's own potential, promotes the relational attitude towards other people and shapes a holistic, integrated development. ${ }^{32}$ The 
pope's conscious emphasis on the stature of the family and its rights as elementary guidelines for national and European policies should be, in line with his postulates, supported by an appropriate employment strategy based on the dignity of the ethos of work. This aspect of public policy guarantees material security for families and creates an innovative and responsible social attitude. In the pope's opinion, in the context of family rights and the right to employment, one must not forget about the human capital of immigrants, whose presence on the European continent can in many ways enrich its weakened potential and alleviate labour shortages. These challenges, in his conviction, require the European community to provide adequate support for the cultural identity of individual nations, clear legislation protecting the rights of citizens - but also of immigrants, who in the current circumstances constitute an important part of the Old Continent's community. ${ }^{33}$ Importantly, the pope emphasises that modern Europe is primarily responsible for implementing its own rudimentary objectives and overcoming the difficulties associated with them. At the same time, in accordance with his message about openness to the world's periphery, he recommends that Europe should feel ready to help non-European countries, especially those whose difficult economic and political situation causes mass emigration of their citizens to the Old Continent. Europe should be a pioneer in addressing these important causes of migration and in promoting a role model of creating civic dignity. Similarly, it should be open to dialogue with countries applying for admission to the EU and to cooperation with those that want to remain outside its sphere of influence. Its particular duty in this respect is cooperation or support in resolving conflicts, some of which are also experienced by EU countries (including religious fundamentalism), or combating international terrorism. This is a primary challenge, especially because these infamous events are fuelled by the arms race, arms trade and human trafficking, all of which stem from contempt for or instrumental treatment of human life. ${ }^{34}$

The problems caused by an inefficient migration policy and numerous violent conflicts mainly due to ideological (including religious), ethnic and economic reasons, constitutes one of the most acute symptoms of the weaknesses of modern Europe that trouble the current pontiff. In Francis's opinion, these negative phenomena are fuelled by the desire to dominate others or to possess worldly goods and constitute another example of how Christian humanism is misunderstood. The pope reminds in this context that the rejection of the so-called culture of conflict, embroiled in intimidation or marginalisation of people with different views or lifestyles, requires long-term, continuous education in a spirit of peace and communal cooperation. Each conflict must be faced, because ignoring it causes internal emaciation, distrust and fear, slipping into fruitless contradictions and horizontal inwardness that typically erode interpersonal relations, deepen tensions and unfortunately claim innocent victims. ${ }^{35}$ In Francis's opinion, the pursuit of peace should not be understood only in terms of avoiding conflicts and wars, or as temporary truces imposed by utilitarian agreements. True peace is characterised by free and 
fraternal spiritual reconciliation. The future of Europe needs a memory of the past based on true humanitarianism, not on mechanical, formalised and uniform policies of states and European institutions. ${ }^{36} \mathrm{He}$ therefore instructed Europe (or rather its decision-makers) not to evade the obligation to constantly reflect on whether its humanistic, artistic, technical, social, political, economic and religious heritage is only a relic of the past and whether the current appearance of permanence can still be an inspiration for mankind. In his view, the leading role in the implementation of this task falls to the Council of Europe and the European Court of Human Rights (the guardian of respect for human rights), which should always bear in mind the historical heritage of the continent on which the founding fathers built its post-war history. This is a prerequisite if Europe wants to be a multilateral leader and reference point for the rest of the world. Its leaders must remember that creativity and the ability to go beyond one's own limits lie in the nature of this continent. It was proven by overcoming the tragic effects of wars experienced by Europe in the 20th century. Resignation and fatigue (as in the symbolically evocative figure of the 'grandmother') are therefore not an inherent feature of this part of the globe, and all obstacles should be treated as catalysts for unity. ${ }^{37}$

\section{Conclusion}

In summary, it ought to be emphasised that Francis, like his two great predecessors on the Chair of Peter, is able to accurately diagnose the weaknesses of the Old Continent. At the same time, his positive advice to Europe's residents and institutions, which is intended to promote the solidarity, peace and unity of the continent, in principle does not diverge from the key postulates of John Paul II and Benedict XVI. Of course, the social and structural threats in modern Europe are different (increased migration, 'ideological colonization', dictate of formalism and institutional centralism), or reveal the intensification of previously existing problems (economic disparities, a 'culture of exclusion', religious fanaticism, secularism, dechristianisation, terrorism). This has resulted in enriching Francis's teaching in comparison with the previous pontiffs by adding new, consequential and accurate reflections. It is also worth noting that in their predictions and instructions, all popes used a language that was characteristic of their pontificates, which probably makes their teaching seem more differentiated. What they undoubtedly share is the message that Europe cannot abandon its cultural and ideological heritage, on which it was founded and which is the direction for its future. In the case of Francis's teaching, the need for Europe and the Church to undergo mental renewal and institutional reform in line with the original spirit of the Gospel is clearly exposed. The pope's recommendations about the necessity of spiritual and institutional transformation are formulated due to his fear of the possibility of the collapse of Europe, which is often weak, inefficient and deprived of vitality. In his view, this disturbing sign of the times in the 
form of both religious and secular order plunging into 'spiritual worldliness' requires a revival of the Christian aspect of humanism. For Francis, it simply means a 'continuous process of humanization', undisputedly founded on a transcendent and relational human nature, whose dignity and rights ought to be guarded by law-abiding democratic states and supranational organisations. The pope is convinced that this fundamental premise enables the recreation of a truly universal spiritual community, which is the sine qua non of the cultural and ideological foundation of a united Europe. At the same time, it guarantees solid international relations based on solidarity. What is more, he predicts that it will result in structures which, instead of following purely technical and dehumanised rules, respect solutions based on the multicultural identity of nations and grassroots activity of all generations, truly serving the process of the integration of the continent.

\section{Notes}

1 Grzegorz Polak, Franciszek. Papież wielkiej nadziei, (Znak 2013), 138.

2 See more in enunciations of John XXIII (Mater et Magistra, Pacem in terris) and Paul VI (Populorum Progressio, Octogesima Adveniens); cf Marian Banaszak, 'Historia Kościoła Katolickiego. Czasy najnowsze 1914-1978', (1992), 4, Akademia Teologii Katolickiej, 337-361; Zygmunt Zieliński, Papieże i papiestwo dwóch ostatnich wieków, (3rd edition, Pax 1999), 413-429, 438-490.

3 Polak, (n 1), 127, 138.

4 In the opinion of the Italian historian Aldo Giannuli, the universalist course of John Paul II was somewhat abandoned by his successor in favour of Eurocentrism. In the opinion of the researcher, unlike Benedict XVI, who focused mainly on the crusade against the threat of relativism to Western civilisation, Francis would rather continue the openness of the Polish pope to understanding and establishing dialogue with the whole world. Aldo Giannuli, Papa Francesco fra religione e politica. Chi è, quale Chiesa si trova a governare, quali sfide globali dovrà affrontare, (Adriano Salani Editore S.p.A. 2013), 68, 74; Tomasz Terlikowski, Operacja Franciszek. Sześć medialnych mitów na temat papieża, (Fronda 2014), 34.

5 John Paul II, 'Discorso di Giovanni Paolo II durante la visita al Parlamento Europeo, 11 October 1988', (1988) ed Polish L'Osservatore Romano, (11), 11 and John Paul II, 'Homily at the Cathedral of Gniezno on the 1000 year anniversary of the death of St Adalbert, 3 June 1997' in Leszek Sosnowski and Gabriel Turowski (choice and elabor.), Europa zjednoczona w Chrystusie: Antologia, (Biały Kruk 2011), 306.

6 Joseph Ratzinger, Europe: Today and Tomorrow, (San Paolo 2004), translated into Polish by Stanisław Czerwik (Jedność 2005), 9-11, and more broadly: Tomasz Schramm, Tożsamość Europy a chrześcijaństwo, (Księgarnia Św. Wojciecha 2005).

7 Giannuli, (n 4), 75; cf Heribert F Koeck, 'Szczęście w nieszczęściu. Jak dużego kryzysu potrzeba, aby zreformować Unię Europejską?' in Eugeniusz Piontek, Katarzyna Karasiewicz (eds), Quo vadis Europo III?, (Urząd Komitetu Integracji Europejskiej 2009), 29, 34.

8 The outline of the programme of reforms and renewal of the Church presented by Jorge Bergoglio, and later Francis, clearly refers to the guiding ideals of the 
mendicant orders, initiated by the Franciscan and Dominican communities in the so-called New Middle Ages. Their main goal was to preach the Gospel in the spirit of the first disciples. Marian Banaszak, 'Historia Kościoła Katolickiego. Średniowiecze', (1989), 2, Akademia Teologii Katolickiej, 183-189. It should also be noted that this direction of the renewal of the Church appeared in the concept of accomodata renovatio, initiated by Leo XIII and strongly emphasised during the pontificates of John XXIII and Paul VI, although it was not directly referred to by Francis. Cf Rerum Novarum. Encyclical of Pope Leo XIII on Capital and Labour in Nauczanie społeczne Kościoła, (Ośrodek Dokumentacji i Studiów Społecznych 1984), 12-35.

9 There is more on Francis's understanding of 'spiritual wordliness' in Evangelii Gaudium (Święty Paweł 2014), pt. 93-97; Andrea Tornielli, Jorge Mario Bergoglio: Francis: Pope of a New World, (Piemme 2013), translated into Polish by Krystyna Kozak and Krzysztof Stopa (Jedność 2013), 128, 131-132.

10 Giannuli, (n 4), 97.

11 Austen Ivereigh, The Great Reformer: Francis and the Making of a Radical Pope, (Allen \& Unwin 2015), translated into Polish by Marcin Masny (Niecałe 2015), 417.

12 Not all founding fathers were guided by Christian values founded on transcendent dignity, to which Francis refers. For more, see footnote 7 in Ewa Kozerska, Papiez Franciszek o prawie (2016) XV, Miscellanea Historico-Iuridica, 2, 343, 346.

13 Francis, 'Between Dignity and Transcendence: Address of Pope Francis to the European Parliament, 25 November 2014', (2014) ed Polish L'Osservatore Romano, 12, 9-10; cf also Francis, 'What Happened to You, Europe? Address of His Holiness Pope Francis - Conferral of the Charlemagne Prize, 6 May 2016', (2016) ed Polish L'Osservatore Romano, 5, 30.

$14 \mathrm{Cf}$ Francis, Laudato Si, pt. 46, 109, 117 www.vatican.va/content/francesco/ en/encyclicals/documents/papa-francesco_20150524_enciclica-laudato-si.html accessed on 10 July 2020; Bergoglio, 'Homily of 25 March 2012' translated into Polish by Xavier Bordas i Hanna Prószyńska-Bordas in Chciałbym Kościoła ubogiego dla ubogich, (M 2013), 66; Aldo M Valli, Le sorprese di Dio. I giorni della rivoluzione di Francesco, (Ancora 2013), translated into Polish by Krystyna Kozak (Jedność 2015), 34-37.

15 Cf Francis, Laudato Si, pt. 111, 118; Walter Kasper, Witness of Mercy, (Mauri Spagnol 2015), translated into Polish by Michał Szwemin (ARTI 2016), 26-27.

16 Francis, 'Between Dignity and Transcendence: Address of Pope Francis to the European Parliament, 25 November 2014', (n 13), 9-13; cf also Francis, 'What Happened to You, Europe? Address of His Holiness Pope Francis - Conferral of the Charlemagne Prize, 6 May 2016', (n 13), 34; and Valli, (n 14), 31-32.

17 In the context of the inherent features of human nature, Francis refers to the formula of 'human ecology' used by his predecessor Benedict XVI ('The Listening Heart. Reflections on the Foundations of Law: Speech at the Bundestag on 22 September 2011', (2011) ed Polish 'L'Osservatore Romano, 10-11, 38, 41). It is worth noting, however, that in Francis's teaching the issue of human relativity, as he terms it, is much more highlighted than in the previous pontificate due to the currently more significant breakup of bonds and social unity. Francis, 'Between Dignity and Transcendence: Address of Pope Francis to the European Parliament, 25 November 2014', (n 13), 9-11; and Francis, Laudato Si, pt. 43, 81, 119, 216; cf Bergoglio, 'Seminar of 30 September 2009: The Social Debts of Our 
Time', translated into Polish by Krzysztof Gołębiowski, in 'Chciałbym Kościoła ubogiego dla ubogich',(n 14), 34-35.

18 Francis, 'Do Not Forget About Your Roots: Apostolic Journey of His Holiness Pope Francis to Romania, 1 June 2019', (2019), 7-8, ed Polish L'Osservatore Romano, 27, 28; cf. Andrea Tornielli, 'A Road Map for the Future of Europe and its Inhabitants', (2019), 7-8, ed Polish L'Osservatore Romano, 16, 17.

19 Francis, Laudato $\mathrm{Si}$, pt. 75.

20 Francis, 'Between Dignity and Transcendence: Address of Pope Francis to the European Parliament, 25 November 2014', (n 13), 11.

21 This motto was announced at the session of the European Parliament on 4 May 2000. More: Dorota Jurkiewicz-Ekhert, 'Od Traktatu o Unii Europejskiej do Europejskiej Agendy dla Kultury - narodziny i rozwój polityki kulturalnej UE', (2015), 1, Studia Europejskie, 65, 65-67.

22 Francis, 'Between Dignity and Transcendence: Address of Pope Francis to the European Parliament, 25 November 2014', (n 13), 11-12; Francis, 'What Happened to You, Europe? Address of His Holiness Pope Francis - Conferral of the Charlemagne Prize, 6 May 2016', (n 13), 31. Cf. Jorge Bergoglio and Abraham Skorka, On Heaven and Earth. Pope Francis on Faith, Family and the Church in the Twenty-First Century, (Random House Mondadori S.A. 2010), translated into Polish Marta Szafrańska-Brandt, (Znak 2013), 85-88.

23 Francis, Evangelii Gaudium, pt. 231-233; and Bergoglio, True Power Is Service, (Editorial Claretiana 2013), translated into Polish by Agnieszka FijałkowskaŻydok (Esprit 2013), 73, 324-326.

24 Francis, 'Between Dignity and Transcendence: Address of Pope Francis to the European Parliament, 25 November 2014', (n 13), 11. The pope metaphorically illustrated the condition of modern Europe also by referring to poems by the Italian poet Clemente Rebora ('Il pioppo' in Canti dell'Infermita, Vanni Scheiwiller 1957), whose spiritual transformation caused his accession to Catholicism, in Francis, 'Memory, Courage, Utopia: Address of Pope Francis to the Council of Europe, 25 November 2014', (2014) ed Polish L'Osservatore Romano, 12, 14, 15.

25 Cf Francis, Evangelii Gaudium, pt. 94. Cf also Bergoglio and Skorka, (n 22), 151-158.

26 Francis, 'Between Dignity and Transcendence: Address of Pope Francis to the European Parliament, 25 November 2014', (n 13), 11; Francis, 'Memory, Courage, Utopia: Address of Pope Francis to the Council of Europe, 25 November 2014', (n 24), 17.

27 Francis, 'Between Dignity and Transcendence: Address of Pope Francis to the European Parliament, 25 November 2014', (n 13), 12.

28 Francis, 'Memory, Courage, Utopia: Address of Pope Francis to the Council of Europe, 25 November 2014', (n 24), 16-17; cf Jorge Bergoglio, Exactingness and Passion: Challenges for Christian Educators, (Editorial Claretiana 2013), translated into Polish by Lidia Wrona (Esprit 2013), 113.

29 Francis, Evangelii Gaudium, pt. 234-236; cf Bergoglio, Exactingness and Passion: Challenges for Christian Educators, (n 28), 107-108; cf Kasper, (n 15), $35,37$.

30 Francis, Evangelii Gaudium, pt. 255-256; Francis, 'Dialogue and Cooperation against Fundamentalism: Apostolic Journey of His Holiness Pope Francis to Morocco, 30 March 2019', (2019) ed Polish L'Osservatore Romano, (4-5), 20, 20-23. 
31 Francis, Evangelii Gaudium, pt. 255; Francis, 'Memory, Courage, Utopia: Address of Pope Francis to the Council of Europe, 25 November 2014', (n 24), 18.

32 Francis, 'Between Dignity and Transcendence: Address of Pope Francis to the European Parliament, 25 November 2014', (n 13), 12; cf Francis, 'Dialogue and Cooperation against Fundamentalism: Apostolic Journey of His Holiness Pope Francis to Morocco, 30 March 2019', (n 18), 28; cf Bergoglio, Open Mind, Faithful Heart, (Editorial Claretiana 2013), translated into Polish by Małgorzata Łuszczak and Małgorzata Grygierowska (Esprit 2013), 122.

33 Francis, 'Between Dignity and Transcendence: Address of Pope Francis to the European Parliament, 25 November 2014', (n 13), 13; cf Francis, 'Dialogue and Cooperation against Fundamentalism: Apostolic Journey of His Holiness Pope Francis to Morocco, 30 March 2019', (n 30), 21. The problem of migration in the teaching of this pope is a constant object of reflection and pastoral care. Francis, 'Message of His Holiness Pope Francis for the 101st World Day of Migrants and Refugees, 3 September 2014', (2014) ed Polish L'Osservatore Romano, 10, 4-5; Francis, 'Message of His Holiness Pope Francis for the World Day of Migrants and Refugees, 15 September 2015', (2015) ed Polish L'Osservatore Romano, $10,10-12$.

34 Francis, 'Memory, Courage, Utopia: Address of Pope Francis to the Council of Europe, 25 November 2014', (n 24), 15.

35 Cf. Francis, 'Message of His Holiness Pope Francis for the Celebration of the 53rd World Day of Peace' 1 January 2020, http://w2.vatican.va/content/francesco/en/ messages/peace/documents/papa-francesco_20191208_messaggio-53giornatam ondiale-pace2020.html accessed on 10 May 2020.

36 Francis, 'Between Dignity and Transcendence: Address of Pope Francis to the European Parliament, 25 November 2014', (n 13), 13; cf Francis, 'Memory, Courage, Utopia: Address of Pope Francis to the Council of Europe, 25 November 2014', (n 24), 14.

37 Francis, 'Memory, Courage, Utopia: Address of Pope Francis to the Council of Europe, 25 November 2014', (n 24), 16; Francis, 'What Happened to You, Europe? Address of His Holiness Pope Francis - Conferral of the Charlemagne Prize, 6 May 2016', (n 13), 31; Kasper, (n 15), 82-83. 


\section{Index}

Note: Page numbers in bold refer to tables and those in italic refer to figures.

Abascal, Santiago 46, 67

ABC's of a Russian Nationalist, The 171-2

Abts, Koen 186

acquiescence $79-80$

activists (activism) 39, 40, 54, 80, 87,

$112,118,121,162,163,166,168,170$, $174,177,178$

Address of Francis to the EP 248, 259n 18-37

affluence 28

Agamben, Giorgio 223, 224

Ágh, Attila $225 \mathrm{n} 1$

agriculture 100, 123, 167

Aktion Neue Rechte (ANR) 38

Aktionsgemeinschaft Unabhängiger

Deutscher (AUD), party 37

AKKEL party 120

Alexander Jeffrey C. 142n2

Alleanza Nazionale (AN) see National

Alliance

Alliance of Free Democrats (SZDSZ) 130-1

Alliance of Liberals and Democrats for Europe (ALDE) 189

alliances 17, 38, 39, 51, 56, 67, 71, 76-8, $80,81,83,86,120,125,130,134,155$, 174, 179, 189, 197

All-Polish Youth (Poland) 119

Almeida, Dimitri 58n15

Almirante, Giorgio 61, 68, 74

ambiguity 53, 211

Anderson, Benedict 90, 94, 104, 142

ancien regime 202, 207-9

anthropology 93, 144n36, 249, 251

Antall, József 131, 143n8

Antonić, Slobodan 158n24

Aprile, Pino 21n 40

Arab Spring 63 aristocracy 93, 121, 128, 167

Aristotle 167, 254

Armstrong, Stephen 105n31

Arndt, Hans J. 40

Art, David 7n2, 57n7

Artemov, Igor 175

artists 139

Artmov, Igor V. 175

Ash, Timothy Garton 14, 20n23

Ashby, Jonathan 105n 32

Asshauer, Thomas 47n5

Assemblée Nationale 55

Assembly of Wales 96

associations 25, 36, 40-2, 151, 170, 173,247

asylum seekers 196

athletes 139

Attila, Antal 133, 143n 12

austerity $12,69,83,87,88,97,102,187$

Austria 22-3, 46, 50, 66, 71, 82, 89n15, 190, 211

Austro-Hungary 22-3

authoritarianism $82,106,108,137$, $148,161,171,180 \mathrm{n} 6,211,214 \mathrm{n} 36$, $215 \mathrm{n} 50,225 \mathrm{n} 1$

authority $15,16,43,63,102,103,110$, $112,117,120,124,133-5,138,140$, 141, 169-70, 173, 177, 208, 221, 231, 235,245

autonomy 1, 4-5, 29, 63, 65, 77, 81, 85, 108-10, 112, 226n16, 232, 254

Averyanov, Vitaly 169

axis Franco-German 67, 69, 72

Baburin, Sergey 168

Backes, Uwe 37, 47n5, 47n6, 202, 209, $212 \mathrm{n} 2,214 \mathrm{n} 37$

Bacon, Francis 166 
ballots $82,86-7,115,185,188,197-9$

Baile, Tusnad 137

Balcer, Adam 238n 20

Bal, Mieke 142n3

Balog, Zoltán 141

Balogh Lászlo L. 143n18

Banaszak, Marian 257n2, 258n8

Bandović, Igor 150, 158n22, 158n25

Bankuti, Miklós 143n10

banking systems 69

Bardèche, Maurice 37

Bárdi, Nándor 143n22

Barghoorn, Frederick Charles 161, 180n3

Barkashov, Aleksandr 171, 172, 181n42

Barnett, Joel 97; Barnett Formula 97, 98, 104n20

Bar-On, Tamir 59n33

Bartsch, Günter 47n7

Basic Law of Hungary 136

Basmanov, Vladimir 177

Battistini, Francesco 127n26

Bessenyei, György 128

Bassin, Mark 143n15

Bator, Wiesław 144n37

Battista, Pierluigi 72n6

Bauman, Zygmunt 31n9, 240n51

Belarus 172, 177

Bellucci, Paolo 89n9

Belov, Aleksandr 177

Belovezha Accords 168

Benedict XVI, Pope 246-7, 256, 257n4, 258n17

Benoist, Alain, de 36

Bergoglio, Jorge see Francis, Pope

Berlin Wall 14, 163

Berlusconi, Silvio 60, 76, 78, 80, 87

Bernhard, Michael 200n26, 210, 214n40

Bessenyei, György 128

Betz, Hans-Georg 126n20

Bieber, Florian 211, 215n50

bio-humanism 43

Biorcio, Roberto 88n4

Bíró, Zoltán 131

Bitzan, Renate 7n2

Blair, Tony 96

Blakkisrud, Helge 161, 180n6

Blot, Yvan 52

Bod, Zsolt 144n26

Bogachev, Vladimir 167

Bogdandy, Armin, von 225n4, 227n39

Bolechów, Bartosz 48n18

Bologna Declaration 235, 237n4

Bolshevik Revolution 172
Bolsheviks 165, 167, 172, 174

Bonfreschi, Lucia 74n29

Bonini, Emanuele 74n28

Bossi, Umberto 77-81

Boughton, John 105n33

Bozo, Frédéric 20n 20

Bozóki, András 144n34, 210, 214n46, 215n49

Braginsky, Vladimir 31n12

Brauner-Orthen, Alice 47n1

Break-Up of Britain, The 95, 104n14

Brexit 4, 90-105, 122, 213n23, 215n52; referendum 1, 14, 71, 98

Brexit Party 90-105, 191

Brison, Susan 142n3

British Citizenship Act (1948) 91

British National Party 46

Brothers of Italy (FdI) 3, 5, 60-75, 87, 191; EU policies 69-71; Europe-nation 64-67; nation versus technocrats 67-70; sovereignty 60-63

Browning, Christopher 212, 215n55

Brubaker, Rogers 31n1

Brudny, Yitzak 161, 180n4

Brunazzo, Marco 89n14

Bruneteau, Bernard 16-17, 20n35

Bucciarelli Belardinelli, Dina 241n 70

Bugarič, Bojan 206, 213n26, 225n4

Bulman, May 105n35

Bund Deutscher Solidaristen 39

Bund Nationaler Studenten 37

Buras, Piotr 238n 20

bureaucracy $62,63,67,69,71,85,121$, 137, 236, 250; EU 67, 71, 121

bureaucrats $26,65,67,68,80,121$, $122,144 \mathrm{n} 33$

Burnett, Jon 105n28

Bustikova, Lenka 31n1

Caiani, Manuela 89n14, 186, 191, 199n1, 199n4, 200n14, 200n17, 200n22, 200n28

Cameron, David 94, 99, 101, 103

campaigns $14,20 \mathrm{n} 32,49,52,62,68,81$, $82,110,116-18,123,132,158$ n 30 , $185,187-8,220-1,238$ n18, 239n32

Camus, Jean-Yves 56n2

Canfora, Luciano 15, 20n25

Cantle, Ted 104n7

capitalism 36, 39, 83, 120, 131, 166-8, 175,179

car emissions 188, 194-5, 197

care, old age 97

Carter, Elisabeth 57n6 
cash machines, EU as 26-7

Castelli Gattinara, Pietro 57n5

Castro, Fidel 72n8

Catalonia 4, 106-13, 114n16; EU 110-111; in European history 107-109; independence-real or utopian 109; quo vadis Europe? $112-114$; voters and political prisoners $111-112$

Cavour, Camillo Benso 17

CDU, party 35, 38, 41

Central Europe 6, 31n1, 45, 58n23, 131, 134, 137, 138, 171, 200n20, 202-15, $225 \mathrm{n} 1,238 \mathrm{n} 16$

Central European Bank 80

ceremonies 64

Cercel, Cosmin 225n7, 225n12

Charter of Fundamental Rights (CFR) 27-8, 220, 228, 231, 242n88

Charlemagne Prize 258n13, 259n22, 260n37

Chequers Affair 14-15, 20n23

child adoption, same-sex 62

Chiarini, Roberto 72n3

China 5, 39, 69, 138, 139, 146, 154, 155,175

Chirac, Jacques 16

Christian identity 65, 66

Christianity 24, 28, 43, 65, 137, 139, 140, 164, 174, 231, 245, 247, 251

Christlich-Konservatives Deutschland-Forum (CKDF) 41

Ciampi, Carlo Azeglio 64

Ciążela, Andrzej 238n 30

citizens $4,6,17,22,23,28,42,62,67-70$, $85,115-18,121-5,130,132-4,142$, 154-7, 160, 163, 165, 176, 177, 185, 190, 193, 197, 205, 209, 211, 228, 229, 232, 235, 236, 237n8, 254, 255; Brothers of Italy 67, 69; Poland 117-118, 121, 124-5

citizenship 25, 63, 91, 92, 104n12, 106, $132-5,141-2,229,237,253$

Civil Development Forum 120

civil rights 43, 79

Claris, Pau 107

Clark, Christopher 19n8

Coala, Gino 67, 74n 40

coalitions 28, 38, 76, 78-80, 85-7, 101, $108,123,125,132,133,140,146$, 148-53, 151, 156, 158n21, 190, 192, 194, 195, 197, 198, 207, 218, 221

Cochin Appeal 16

Cohen, Robin 104n10
Coles, T. J. 104n 11

collaboration 49, 51-3, 56, 198, 238n11

colonialism 95

colonies, British 91

Common Market 14, 25-7, 57n 7, 68-9

communism 4, 5, 26, 39, 43, 52, 65, $82,116,131,137,141,163-7,172$, 174, 176, 178, 206, 207, 214n40, 230; Russian anti-communist approach 171-173; Serbian 5

communities 11, 22-23, 63, 94, 104n9, $135,142 \mathrm{n} 1,144 \mathrm{n} 33,168,179,234$, 254, 258n 8

Companys, Lluís 108

compensation 27, 69

competition, international 62

conflicts 12-14, 25, 26, 39, 45, 50, 73, 79, $87,88,90,102,106,109-13,120,129$, 130, 141, 146, 148, 149, 192, 200n32, 208, 214n43, 216, 217, 221-4, 236, 237, 250, 255-6; New Right (in FRG) 3, 39, 45; Pope Francis 250, 255

Congress of Russian Communities 168

Congress of the New Right 118-19, 191

Conservative Party 87, 98, 101, 102, 229

Conservative and Unionist Party 102

Constitutional Democratic Party, (Russian Empire) 166-7

Constitutional Democrats 166-7

constitutionalism $6,213 \mathrm{n} 16$, 214n 36, 216-27

construction industry 69

consumers (consumerism) 29, 45, 197, 249

consumption 25

Conte, Giuseppe 69

contexts, political 52-3, 56, 77-80

Conti, Niccolò 89 n 8

Convention on the Rights of the Child $233,240 \mathrm{n} 58$

conservative revolution (konservative revolution) $36,40,47 \mathrm{n} 3$

cooperation $1,3,5,25,38,39,41,49$, 52, 58n $20,63,67-8,70,121,122,124$, $132-5,137,138,144 \mathrm{n} 32,146,154$, $155,167,171,173,174,175,200 \mathrm{n} 27$, 207, 214n $30,220,221,228,233$, 234, 236, 239, 255, 259n30, 260n32;

Brothers of Italy 63, 67; Hungary 135, 138; New Right (in FRG) 38-39, 41;

Poland 118, 121

Corbyn, Jeremy 103

corruption 83, 118, 121, 122, 186, 187, 203

Cortes, Juan Donoso 41 
Cotta, Alain 17, 20n37

Cotta, Maurizio 89n8

Council of Europe 217, 220, 256, 259n24, 259n28, 260n31, 260n34, 260n $36,260 n 37$

Court of Justice of the European Union (CJEU) 213n14, 218

COVID-19 69, 72n7, 76, 87-8, 102

Craig, Gordon 14-15

Crépon, Sylvain 58n27

Csergő, Zsuzsa 138, 143n16, 143n21

crimes, organised 63,122

crises 12, 24-5, 199n1, 200n20; Salvini's

League 80, 82-3, 87-8

crises, economic 12, 76, 81, 154, 185

Cristin, Renato 66, 73n21

Criticòn 39-40

Crosetto, Guido 60

Csehi, Robert 208, 214n35

Csergö, Zsuzsa 138, 143n16, 143n21

Csoóri, Sándor 131

CSU party 35,38

Csurka, István 131

cultural nationalists, Russian 175-6

cultures, national 24, 138, 231

currency, common 1, 69, 134

Czech Republic 66, 71, 82, 190

Czerniawska, Mirosława 240n46

Cześnik, Mikołaj 158n36

Dačić, Ivica 148, 149, 151, 152, 158n33

Daddow, Oliver J. 18, 19n17, 21n41

Dajč, Haris 5, 146-59

Daly, Tom Gerald 225n15

Danish People"'s Party 46, 50, 190

Davis, Richard 19n16

Debreczeni, József 145n41

decisions 29, 54, 68, 69, 100, 103, 108, $111,121,122,128,141,192,199$, 208-9, 215n48, 218, 220

Dehoust, Peter 37

Del Monte, Filippo 73n10

Delors, Jacques 228, 237n1

Dumezil, Georges 42

democracy 4, 5, 26, 28, 38, 45, 61, 65, $66,94,106,107,117,121,122,133$, 136-8, 148, 180, 175, 186, 190, 203, 206, 208, 211, 212, 216-19, 221, 222, 224, 229, 233, 235, 237, 240n58, 251,254

democratic backsliding 202, 211

Democratic Party (DS) 148

Democratic Party of Serbia (DSS) 148, $150,151,152-4,156$
Demushkin, Dmitry 173

deprivation 98, 178

Derrida, Jacques 227

Deutsche Einigung 13

Deutsche Gemeinschaft (DG) party 37

Deutsche Volksunion 36

Deutschland in Geschichte und Gegenwart 40

devolution 78, 95-102; English 95-98

De Vries, Catherine E. 57n11

De Winter, Lieven 88n6

Dézé, Alexandre 58n27

Diamanti, Ilvo 88

diaspora 130, 131, 133-6, 138, 142

Dickson, Annebelle 104n13

Diec, Joachim 5, 160-82

Di Maio, Luigi 120, 127n27

Đinđić, Zoran 148, 150

Diószegi, Vilmos 144n36

discrimination 232, 237, 239n34, 254

Disraeli, Benjamin 90

dissimulation 93

distribution 12, 27, 166, 187, 196, 245

diversity 43, 66, 68, 94, 106, 138, 160, 185-201, 229, 234-6, 237n11, 242n80, 246, 251, 253; cultural 66, 106, 138,246

diversity, cultural 66, 106, 138, 246

Diwald, Hellmut 40

Dołbakowska, Magdalena 158n36

Dosta je bilo (DJB) see Enough is Enough

Dostoevsky, Fyodor 162

DPNI see Movement Against Illegal Immigration

Dual Citizenship Act 134

Dublin Regulation 196

Dubois, Mathieu 19n12

Duda, Andrzej 238n18, 239n32, 239n41

Dugin, Aleksandr 170, 171, 181n35

Dunlop, John B. 161, 172, 180n5, 181n42

Durkheim, Émile 206

Deutsch-Soziale Union (DSU), party 37

Dveri, party 151, 151, 153, 155, 156

Dzhemal, Geydar 170

Eatwell, Roger 47n1, 57n8

Economides, Spyros 157

education, Polish patriotic 232-5

Education, The Treasure Within 228

Edwards, Erica E. 57n11

Egedy, Gergely $143 n 7$

egocentrism 249

Eibl-Eibesfeldt, Irenäus 42, 48n21

Eichberg, Henning 37, 43 


\section{Elemente 41}

elections 1, 4, 16, 24-5, 38, 46, 49, 51, $55,57 \mathrm{n} 7,58 \mathrm{n} 18,59 \mathrm{n} 30,60,62,63$, 67-9, 71, 74n40, 74n42, 76-8, 87, 108, $115-18,120,121,123-5,127 \mathrm{n} 38$, 131-6, 139, 144n27, 145n41, 147, 149-51, 151, 152, 158n29, 158n35, 167, 189, 200n26, 200n31, 200n33, 208, 209, 222, 238n18, 239, 247; Poland 116, 118, 120, 123, 125; Rassemblement National (RN), 51, 55; Salvini's League 76-80, 87

Eliade, Mircea 42

elites 1, 3, 4, 6, 7n1, 22-6, 30-1, 44, 83, $93,101,116,120,135,144 \mathrm{n} 33,148$, 165, 185, 187, 203, 204, 206, 209; EU 25-26; Hungary 130, 135; Poland 116, 120; Russia 165

Elizabeth II, Queen 92

embezzlement 112

embryology 44

emissions, car 188, 194-5, 197

empathy 237n11, 253

empires 22, 23

employers 44, 105n30

employment 62, 99, 100, 198, $24 \ln 59,255$

energy crises 12

Englishness 91, 96

Enough is Enough (DJB), party 150-4, 151

entanglement, rule of law 219-21

enterprises 40-1, 62, 69-71, 83

environment, natural 123, 166, 197, 198

equality $1,25,27,43,66,110,122$, 187, 188, 195-9, 226n23, 229, 235-7, 238n18, 239n34

Ermolaev, Vladimir 177

Estonia 172, 190

'ethics 46, 109, 113-14, 168, 240n58, 246, 251

ethnicity $30-1,91,103,160-1,180 \mathrm{n} 6,253$

ethnonationalism 138, 140

ethnopluralism 43, 44, 47n4

Eurasianism 134, 143n15, 174; neo-Eurasianism 171, 179

Eurasianists 170, 178-9

Eurocentrism 57n5, 245, 249, 257n4

Europe of Freedom and Direct Democracy (EFDD) 189, 191, 192-9, 192, 194-7

Europe of Nations and Freedom (ENF) 1-2, 82, 189, 190, 191, 192, 193-4,

195-8, 196-9
Europe, two-Speed 68

European arrest warrants (EAWs) 220

European Border and Coast Guard Agency (FRONTEX) 123

European Central Bank (ECB) 69, 70

European civilisation 6-7, 53-6, 65, 69, 166, 251

European Coal and Steel Community (ECSC) 11

European Community (EC) 11, 12, $18,26,95,111,112,134,229,246$, 250, 253-5

European Conservatives and Reformists (ECR Party) 70-2, 72n2, 74n42, 151, 158n28, 189, 190, 191, 192, 192, 194, 194-8, 197, 199, 229, 230, 238n14, 238n24

European Constitution 79-80

European Council 200n31, 203, 213n15

European Court of Human Rights 256

European Defence Community (EDC) $11,19 n 2$

European Economic Community 3, 19n9, 49

European Manifesto, The 120, 127n36

European Parliament (EP) 1, 3, 6, 16, 46, 49-52, 55, 56, 57n7, 58n18, 58n20, 60, $62,68,69,70-1,74 \mathrm{n} 42,82,88,120-2$, 127n38, 132, 144n27, 185-201, 203, 208, 213n13, 226n22, 226n24, 227n31, 228-30, 237n5, 237n10, 248, 258n16, 258n17, 259n21, 260n32

European People's/Popular Party (EPP) 189, 190, 191, 192, 192, 194, 194-7, 195-8, 214n31

European Stablity Mechanism (ESM) 69-70

European Union (EU) 1-3, 11, 15-19, 19n9, 24, 45, 46, 49-56, 58n17, 60, 71, 79, 84, 85, 98, 99, 101, 102, 105n26, 106-14, 121, 122, 128-47, 149, 153-6, $157 \mathrm{n} 1,174,185,187-8,195,200 \mathrm{n} 34$, 203, 208, 213n14, 216-18, 225n4, 226n22, 228, 230, 236, 237n2, 239n37, 242n $88,248-51$

Eurorealism 1, 119-20; Euro-realistic 2, 71; see also Eurorscepticism soft

Euroright (Eurodestra) 68, 74n30

Euroscepticism 1, 2, 5, 7n1, 11, 12, 16, 18, 19n1, 19n16, 20n18, 21n41, 22-31, $49,50,57 \mathrm{n} 11,57 \mathrm{n} 12,58 \mathrm{n} 21,58 \mathrm{n} 23$, 71, 75n46, 83, 85, 89n19, 98, 119-20, 126n $23,137,147,149-53,155-7$, 157n13, 158n18, 159n49, 187, 199n3, 
200n20, 200n33, 216, 217, 238n15; soft 5, 71, 119, 137, 149, 152, 187, 229; see also popularism, right-wing euthanasia 44

Evangelii Gaudium 248, 258n9, 259n23, 259n25, 259n29, 259n30, 260n31

Evans, Geoffrey 105n 25

Evola, Julius 37, 42

exclusions 23, 94, 111, 193, 249, 256

exclusivism 6

experts $99,117,161,169$

extremism 3, 36, 37, 57n6, 80, 82, 199n8, 252-3

Eyerman, Ron 142n2

\section{Faces of Contemporary Russian} Nationalism 161, 180n5

Falkner, Gerda 186, 199n9

families $25,69,82,85,100,185,231$, $233,237,255$

fanaticism, religious 246, 256

Farage, Nigel 100, 101, 103

fascism 59n33, 61, 77, 133, 168, 174, 212

fatherland $60-5,67,191,230$

February Revolution (1917) 166-7

FDP party 35

Federal Republic of Germany (FRG) 3, $12,14,18-48$

federalism 50-1; European 20n28, 68,123

Feit, Margret 47n9

Fetscher, Irving 48n19, 48n20

Fidesz party $6,133,135,208,216$; rule of law 207-9, 218

Fiedler, Hans-Michael 37-8

Fieschi, Catherine 50, 57n4, 58n17

Fijał, Małgorzata Maria 4, 115-27

financial markets 123

financial support 69-70

Fini, Gianfranco 61, 68, 73n14, 74n31

First Chechen War 163

Fisch, Jörg 227n43

Five Star Movement (FSM) 4, 82, 89n11, 120, 186, 191

flags 92-3, 106

Forde, Chris $105 \mathrm{n} 30$

Ford, Robert 105n36

foreigners 41, 66, 73n21, 78, 133, 134, 177

Forsthoff, Ernst 42

Forza Italia (FI) 78, 80, 87, 88, 187

Fragmente 37-8

Francis, Pope 7, 245-60; critical assessment of modern Europe 247-50; renewal of European community $250-6$
Franco, Francisco 108

Fratelli d'Italia (FdI) see Brothers of Italy

Freeden, Michael 103n4

freedom 14, 27, 29, 37, 38, 55, 61, $62,64-7,70,82,95,108,109,113$, 140, 145n41, 154, 163-7, 187, 208, 210, 229-30, 233, 234, 237, 240n58, 251, 253

Freedom Party of Austria 46, 190

Freiheitliche Deutsche Arbeiterpartei (FAP) 40

Freiheitliche Partei Österreichs (FPÖ) 39-40

French Parliament 55

Frexit 49, 59n30

Freud, Sigmund 227n51

Freyer, Hans 42

Froio, Caterina $57 \mathrm{n} 10$

Front National 49, 56n1, 56n2, 57n3, 58n21, 59n29, 59n35, 82

Fuchs, Dieter 7n1

Fursdon, Edward 19n2

funding 97, 101-2, 104n21, 157n1

funds $26-7,55,56,59$ n $38,88,112,122$, 141,203

Fusi, Carlo 68, 73n14

Gábor, Bethlen 136

Gaffney, John 58n17

Gajda, Janusz 240n44

Galent, Marcin 4, 90-105

Galli della Loggia, Ernesto 64

Gallo, Max 17, $2 \ln 39$

Gallup 13

Ganesh, Bharath 57n10

Garton Ash, Timothy 14, 20n23

Gaudi, Antonio 109

Gaulle, Charles de 16, 67

gay marriage 62

Gdula, Maciej 225n2

Gehlen, Arnold 42

Gellner, Ernest 90, 231, 240n48

gender 62, 195

gender equality $1,25,27,187,188,195-9$

Genschel, Philipp 58n28

Gentile, Giovanni 64-5

Gera, Vanessa 126n17

Gerd-Jaschke, Hans 36, 47n4

German Confederation 14

Germanophobia 2, 11-21; Eurosceptic 12-14; manipulating history $15-18$; misinterpreting historians 14-15

Gerschewski, Johannes 202, 212n4

Giannuli, Aldo 247, 257n4, 258n10 
Giesen, Bernard 142n2

Gifford, Christopher 19n17

Gilbert, Mark 89n19

Glazunov, Ilya 163

Glazyev, Sergey 168, 171

globalisation 1, 30, 55, 66, 67, 79, 81, 82,

$85,133,134,175,189,249$; 'Salvini's

League 79, 81-2

globalism 5, 62, 82, 142

Golden Dawn, party 46, 190

Goldgeier, James M. 138, 143n16, $143 n 21,144 n 29$

Gömbös, Ervin 143n22

Goodhart, David 104n8, 105n37

Goodley, Simon 105n32

Goodwin, Matthew 105n36

Gómez-Reino Cachafeiro,

Margarita 57n9

Górowska-Fells, Magdalena 237n6

Gorbachev, Mikhail 163

Gramsci, Antonio 42

Graziano, Paolo R. 6, 185-201

Great Britian see nationalism, English

Great Russia, party 169, 172

Griffin, Roger 202, 204, 205, 212n1, 213n20

Grob-Fitzgibbon, Benjamin 20n18

Gromadzki, Grzegorz 238n20

Gröller, Harald Dionys 143n18

Grzechynka, Agnieszka 4, 106-14

Grzędziński, Dariusz 125

Guasti, Petra 31n1

Gyáni, Gábor 143n4

Haegel, Florence 20n29

Haider, Jörg 46

Haushofer, Karl 171

Heinisch, Reinhard 57n12

Halikiopoulou, Daphne 57n7, $149,158 \mathrm{n} 18$

Hallstein, Walter 16

Halmai, Gábor 143n10, 214n36, 225n3

Haushofer, Karl 171

Hausleiter, Anton 37

Hazona, Yoram 65

health programmes $85-6$

Héjj, Dominik 145n39

Heppner, Harald 143n18

Hepp, Robert 40

higher education 97, 228, 229, 231, $235,237 \mathrm{n} 5$

historians, misinterpretion 14-15

Historikersreit 40

history 140, 246

history, manipulation of $15-18$ history, regional 22

Hitler, Adolf 13, 14, 16, 17, 18, 37

Hix, Simon 58n18, 200n35

Hobsbawm, Eric 30, 31n11, 90

Hoffer, Eric 204, 213n20

Hooghe, L. 57n11

Homeland, party, (Russia) 163, 168

housing $62,97,100,102,105 \mathrm{n} 35$

human rights $26,76,104 \mathrm{n} 11,109-113$, 114n6, 123, 132, 193, 217, 222, 225, 229, 233, 237, 240n58, 254, 256

Human Rights Watch 111, 114n6

Human Shield party (Croatia) 120, 190

humanism 43, 107, 251, 252, 254, 255, 257

Hungarian Card 131-2, 134-6

Hungarian citizenship 132-5, 142

Hungarian Charter 131_2, 134

Hungarian Democratic Forum (MDF) 130-1

Hungarian Justice and Life Party (MIÉP) 131, 135

Hungarian minority (diaspora) 131, 134, 138,141

Hungary 128-129; Eastern (Asian) turn in 21st century 134-139; within EU 137, 139-142; Fidesz and national unity 131-133; Law and Justice 203, 209; nation concept after 1920 129-130; political transformation after 1989 130-131; rule of law 217-22, 224; and Russia 141

Hussein, Saddam 39

hybridity, rule of law 217-219

Idea of English Ethnicity, The 91, 103n2 identity 28, 45, 106, 125; British 91;

Brothers of Italy 61, 64, 66-67; collective 26, 30; European 66; Greco-Latin-Christian 66; Salvini's League 79, 81, 85

Identity and Democracy (ID) 1-3, 189

identity populism 71

ideocracy 202-15; concept and explanatory power 203-205; re-writing the past, present and future 209-211; sovereign vs. rule of law 207-209; as speech act 205-207

ideotional autocracy 206

Ignazi, Piero 60-1, 72n4, 89n12

Illyés, Gyula 128, 143n11

immigrants $25,30,63,65,82,92-3,99$, $100,114 \mathrm{n} 1,162,177,187,239 \mathrm{n} 32$, 249,255

immigration $63,66,67,70-1,79,81$, 82, 99-100, 138, 196-7; Russian 
Anti-Immigration Activists 177-8;

Salvini's League 78-9, 81-2, 87-8

In Search of the Russian Dream 171 inclusivism 6

independence 4, 5, 16, 23, 29, 54, $55,67,70,77-81,95,102,106-14$; Scottish 101

Independence March 119

Independent 12, 25, 39, 65, 95, 105n 35 , 106, 108-9, 112, 113, 119, 122, 126n17, 151, 152-4, 156, 190, 191, 211,235

Independent Democratic Party of Serbia (S DSS) 151, 152, 154

India $69,93,125 \mathrm{n} 2,211$

individualism 30, 97, 168, 171, 179

infrastructure $62,69,102,103$

Inglehart, Ronald F. 211, 215n52

Initiative der Jugend 38

injustice, sense of 100, 106

Institute of National Remembrance 230

integration, European 1-4, 11-21, 49-59; Eurosceptic Germanophobia 12-14; manipulating history $15-18$; misinterpreting historians 14-15

International Covenant on Civil and Political Rights 110, 233, 240n58

International Monetary Fund (IMF) 69-70

internet 69, 121

Iron Curtain 146

Isernia, Pierangelo 89n8

Islam (Muslim) 2-3, 5, 24, 25, 65, 66, 79, $144 n 33,163,176,177,179-180$

Islamic fundamentalism 70

Islamisation 66, 67, 71

Italian Social Movement (MSI) party 60

Italian Social Movement-National Right (MSI-Destra Nazionale) 60 ius soli 63

Ivaldi, Gilles 58n21

Ivanov-Sukharevsky, Aleksandr 174

Ivereigh, Austen 258n11

Iwanek, Jan 104

Izborskiy Klub, Izborsky Club 171

Izborsky Club 170, 171, 178, 181n38

Jachtenfuchs, Markus 58n28

James, Harold 20n22

Janicki, Kamil 242n78

Jarosz, Ewa 241n67

Jaschke, Hans-Gerd 36, 47n4, 47n6

Jasse, Eckhard 37
Jäger Margarete and Siegfried 47n1

Jeffery, Charlie 104n22, 104n24, 105n38

Jews 44, 93, 165, 174, 234; Russia 162, $165,172,174,176$

Jobbik party 5, 134, 136, 138, 140, 142,196

jobs 55, 62, 83, 99-100, 135

John Paul II, Pope 65, 246, 256, 257n4

John XXIII, Pope 257n2, 257n8

Johnson, Boris 14, 94, 102, 103, $104 \mathrm{n} 12,105 \mathrm{n} 39$

Joseph II 128

Jovanović Ajzenhamer Nataša 158n31

Juncker, Jean-Claude 112, 114n7, 225n1

Jung, Edgar J. 40

Junge Freiheit 41

Junges Forum 38

Junts pel Si 108

Jünger, Ernst 44

Jurkiewicz-Ekhert, Dorota 259n21

justice 5, 6, 14, 27, 37, 61, 70, 94, 110, 113-14, 120, 131, 135, 189, 191, 202-15, 218, 220, 226n23, 228-42

Kaczyński, Jarosław 31n6, 70, 205-7, 209, 210, 213n24, 239n32

Kähönen, Karoliina 120

Kaltwasser, Cristobal Rovira 31n1, 200n18, 212n11

Karasiewicz, Katarzyna 257

Kasper, Walter 258n15, 259n29, 260n37

Kaltenbrunner, Gerd-Klaus 40, 47n13

Kassin, Oleg 172

Kaufmann, Eric 99

Kazinczy, Ferenc 128

Kedourie, Elie 90

Keilitz, Steffen 202, 209, 212n2, 212n4

Kelemen, Daniel R. 225n1

Kelsen, Hans 223

Kenny, Michael 104n16

Kertész, Imre 137

Kim, Renata $241 \mathrm{n} 69$

Kitschelt, Herbert 57n7

Klebelsberg, Kuno Count 130, 143n

Kobiakov, Andrei 169

Kochenov, Dimitry 225n14

Koeck, Heribert F. 257n7

Kohl, Helmut 14

Koliev, Andrey N. 169

Kolstø, Pål 161, 180n6

Kołodziejczak, Małgorzata 126n12

Koncewicz, Tomasz Tadeusz 227n41

Koob Andreas 143n17, 143n20 
Kopecký, Petr 58n23, 229, 238n16

Kopyś, Tadeusz 4-5, 128-45

Korkut, Umut 143n13

Kormak, Marcin 186, 199n8

Körösényi András 144n26

Korovin, Valery 170

Kosowska-Gąstoł, Beata 238n17

Kossuth, Lajos 128

Koštunica, Vojislav 148, 150, 152, 155,159

Köttig, Michaela 7n2

Kövér, György 143n4

Kozerska,Ewa 7, 245-60

Krebs, Pierre 40-1, 48n15

Kriesi, Hanspeter 89n13, 186, 199n10, 200n26

Krylov, Konstantin 175-6

Kubal, Agnieszka 105n29

Kubik, Jan 210, 214n40

Kucherenko, Vladimir 169

Kukiz, Paweł 115, 119, 120, 125n1, $125 n 3,126 n 7$

Kukiz'15 115-27; European programme 119-124; origins of movement 115-117; outline of political ideas 117-119

Kurczewska, Joanna 103n1

Kuzak, Rafał 242n78

La Russa, Ignazio 60, 61

labour markets 29, 57n7, 85, 99, 101, 195, 228, 236

Labour Party (England) 96-8, 101

Labour Party (Poland) 119

Laclou, Ernest 91

Lacroix-Riz, Annie 20n31

Lamperi, Lorenzo 70

Land Decree 167

Lange, Astrid 47n 12

languages $23,63,65,67,82,106-8,114 \mathrm{n} 1$, $119,124,128,129,131,160,168$, 216-28, 231, 232, 234, 236, 253, 256

Laqueur, Walter 47n1, 161, 180n2

Laruelle, Marlène 161, 171, $180 \mathrm{n} 7,181 \mathrm{n} 38$

Lassalle, Ferdinand 37, 44

Latvia 172, 191

Laudato Si 258n14, 258n17, 259n19

Lavrič, Miran 211, 215n50

Law of Justice (PiS) 6, 75n43, 120, 189, 191, 193, 198, 203, 214n43, 214n45, 220, 227n41; national identity 229-32; patriotic education $232-5$
Law on School Education 232-3

leaders, charismatic 45, 49, 117, 140 , 204, 207, 209

League 3, 4, 46, 76-89, 191, 198; Northern League (NL) 46, 50, 77-80, 89n10, 179, 187, 191; see also Salvini's League

Le Bon, Gustave 42

Lecœur, Erwan 57n3

Leconte, Cécile 19n1

Left (-wing) 6, 35, 42, 44, 121, 130, 132, $136,147,149-52,186$

Left Party (Germany) 190

'legacies 5, 13, 26, 36, 42, 133, 137, 140, $147,149,174,178$

legal frameworks 63

Legge Fiano 61

legislation 54-5, 68, 96, 116, 135, 208, 255

Legitimising Role of Palingenetic Myth in Ideocracies, The 202

Legutko, Ryszard 70

Lenk, Kurt 48n17

Leon XIII, Pope $257 \mathrm{n} 8$

Leontiev, Mikhail 171

Le Pen, Jean-Marie 49, 52, 53, $58 \mathrm{n} 24,58 \mathrm{n} 26$

Le Pen, Marine 46, 49, 54, 59n34, 71, 82

Leruth, Benjamin 20n28, 31n2, 159n49

l'état providence 206, 207

Letter to the leaders of the Soviet Union 164

Lewandowski, Arkadiusz 126n6

Lezsák Sándor 131

Liberal-Democratic Party of Russia (LDPR) 167-8, 178

Liberal-Democratic Party of the Soviet Union 167

Liberal Democrats (England) 98, 101

liberalism 1, 17, 40, 133, 142, 170, 210, $211,212 \mathrm{n} 8,221$

Libya 63

Liga Veneta (LV) 77

Liike Nyt party see Movement Now

limitations 53, 76, 167, 188, 204, 222

Lincoln-88 173

Lipset, Seymour M. 88n2

literature $31 \mathrm{n} 1,47 \mathrm{n} 1,137,152,163,164$, 186, 188, 192, 198, 239n34

Locke, John 113, 248

logging 220

London Royal Society 166

Lordon, Frédéric 20n36 
Lorenz, Konrad 42, 70

Lorimer, Marta 3, 49-59

Lostau, Baldomer 108

Maastricht Treaty 17, 20n32, 45, 51-3

MacDowall, Andrew 158n29

Mach, Elżbieta 6, 228-42

Mach, Zdzisław 2, 6, 22-31, 103n1

Machiavelli, Niccolò 42

Macia, Francesca 108

Maciejewski, Marek 3, 35-48

MacKenzie, Robert 105n30

Mackinder, Halford 171

Macmillan, Catherine 19n3

Macmillan, Harold 14

Madonna (singer) 177

magazines 37-41, 45, 54, 104n8

Mahtani, Shibani 104n12

Majewski, Paweł 125n1

Magni-Berton, Raul 7n1

Mandes, Sławomir 239n40, 240n42

Manichean 23, 205

Manifesto for a New Europe 61, 65

Marciniak, Ewa 124, 127n41

Marcks, Holger 143n17

Marcuse, Herbert 38

Markin, Nikolai 174-175

Markowski, Radosław 31n2

Marks, Gary 57n9, 57n11

Marquis, Hugues 19n14

marriages 62, 178

Marsh, Michael 58n18

Marsovszky, Magdalena 143n17, 143n20

Martinelli, Alberto 31n2

Martinez, Jean-Claude 52

Marxism 42, 73n21, 161, 164, 165, 167

Mas, Artur 108

Maschke, Günter 41

materialism 79, 246

Maurras, Charles 42

Mayer, Nonna 56n2, 58n27

Mazzini, Giuseppe 17

McCrone, David 93, 104n6

McDonnell, Duncan 57n12, 58n20

Mcgann, Anthony J. 57n7

Mecklenburg, Jens 47n8

media 14, 17-18, 26-27, 29, 76, 86, 107, $149,171,175,187,213 n 15,226$ n22, 235, 239n32, 254; Russia 5, 22, 36, $46,63,69,87,138,141,146,148-50$, 154-6, 160, 162-79, 171, 175, 180n2, 180n4, 181n38, 181n42, 182n57;

Salvini's League 3, 46, 76-89, 120; see also press
Mediterranean Sea 63

meetings 14, 70, 120, 121, 145n39,

213n15, 215n52, 239n32, 250

Mégret, Bruno 51, 52, 58n25

Meloni, Giorgia 3, 60-75, 76, 87

Meltz, Renaud 19n12

Memory and Identity 61, 65

memory, collective 129, 234

Menon, Anan 105n25

MEPs 49, 51, 55-56, 59n38, 188, 193-8

Mészáros, István 131, 143n6

Michaloliakos, Nikolaos 46

Middle East 63

migrants $3,27,43,63,66,76,105$ n29-31, $142,177,198,260 \mathrm{n} 33$

migration $2,4,29,50,55,69,73$, $100,103,123,135,142,144 \mathrm{n} 33$, 144n36, 176, 196, 198, 238n18, 255, $256,260 \mathrm{n} 33$

military $11,13,18,38,53,63,77$, 171,175

Milliband, Ed 101

Minton, Anna 105n34

Milošević, Slobodan 79, 147-8, 150, 152

Mitteleuropa 45, 171

Minkenberg, Michael 7n2

minorities $1,4,23,24,27,82,92,100$, 130, 131, 133-6, 138, 141, 142, 152, 168, 174, 177, 186, 217, 222, 234, 236

Missus 38

Mitterrand, François 14

Młodzież Wszechpolska (MW) see All-Polish Youth

mnemonic warriors $210,214 \mathrm{n} 43$

mobility 95, 100, 228, 236-7

Moeller van den Bruck, Arthur 40, 41

Mohler, Armin 39, 40, 45, 48n25

Möller, Almut 19n4

monarchy 90-2, 106, 108, 163, 164, 170, 176

monetary upheavals 12

money 27, 97, 98, 100, 251

Monnet, Jean 16

Monti, Mario 80

morality 26, 44, 113-14, 204, 250

Morawiecki, Kornel 207-8

Moreau, Patrick C. 48n20

Mosley, Oswald 37

Movement Against Illegal Immigration (DPNI) 177-9

Movement Now, party, (Finland) 120

Movement of Socialists (PS), party, (Serbia) 149-50, 151, 152, 153, 156, 158n21, 158n 37 
Movimento Sociale Italiano (MSI) see Italian Social Movement

MSI-Destra Italiana see Italian Social Movement-National Right (MSI-Destra Nazionale)

Möllers, Christoph 205, 213n23

Mudde, Cas 31n1, 31n3, 31n5, 57n6, 58n15, 58n23, 89n13, 117, 126n9, 126n20, 126n22, 185, 186, 199n2, 199n7, 199n11, 200n18, 212n11, 229, 238n16

Müller, Jan-Werner 202, 204, 205, 212n10, 213n22

multiculturalism 1, 3, 6, 24, 25, 65-6, 71-2, 104n8, 138, 187, 234, 237

Mussgnug, Martin 37

Mussolini, Benito 48n17, 64, 72n8

muzzle law 218, 220, 221

Nagy, Veronika 225n1

Nairn, Tom 95, 104n14

Nanou, Kyriaki 57n11, 149, 158n18

Napoleon Bonaparte 14, 108

Nation and State 169, 178

Nation Europa 37, 40, 45

national conscience 18,67

national cultures $24,138,231$

national defence 81,239 n33

National Alliance (AN) 60, 61, 68, 72n8, 72n9, 73n13, 74n40, 88

National Communists 172

National Democratic Alliance (NDA) 36, 174, 176, 190-1

National-Democratic Party 176

National Demokratie, party (Belgium) 46

Nationaldemokratische Partei Deutschlands (NPD) 36, 38, 190-1 national identity $2,6,18,23,25,42$, $53-5,63,82,90,92,93,95,122$, 128-31, 134, 140; Hungary 129-30, 139; Poland 229-32; see also nationalism, English

national narratives 210

National Movement 119, 139

National-Patriotic Front (Pamyat) 163-4, 171, 172, 178

National People's Party 174, 178

national preferentialism $85-6$

national pride $38,61,63,138$

National Radical Camp (Poland) 119

National Rally (NR), 3, 46, 49-56, 82, $86,87,169,173,179$; beneficiaries of EU 55-6; European integration 50-1; historical evolution 51-3; ideological approach to Europe 53-5

national recovery 209

national security 69,111

National Socialist Society 173

National Unity Day 135

national unity, Hungarian 131-3

nationalism $1-4,6,22-4,35-48,66$, $68,82,85,87,90-105,128-30$, 133-5, 146-9; see also Prawo i

Sprawiedliwość (PIS)

nationalism, Catalan 4

nationalism, English: break-up of

Britain 4, 94; devolution 94-8;

English backlash 98-102; peculiarities

of British nationhood 90-4; what next? 102-3

nationalism, ethnic $22-4,173$

nationalism, Hungarian 5, 129-30; concept of nation $128,130-1,133-5$, 138; National Unity Day 135; populist tradition 131; and Slavs 129; virtual nationalism 134

nationalism-populism nexus 202, 204-5, 207, 209, 211, 212

nationalism, Russian 5, 160, 178-80; anti-communist approach 171-3; Asian and Caucasian challenges and anti-immigrants 177-8; beginnings 163-7; cultural nationalists 175-6; fallen empire and imperial nationalists 167-71; national socialists $173-4$; pro-Western and democratic nationalists $174-5$; recent analysis 161; religious change 176-7; Serbian 5; theoretical and methodological remarks 160-1; tradition 161-3

Nationalistische Front 39

Nationalrevolutionäre Aufbauorganisation (NRAO) 38-9

nationhood 90-4, 104n16, 176, 222; British 90-4

nativism 82

naturalisation 93

Naumann, Friedrich 45, 171

Nazism 13-15, 18, 36, 48n20, 141, 168, $170,172-4$

neo-Bourbons 17

neo-Turanism 138-9

Nesti, Giorgia 5-6, 185-201

New Labour, party 103

New Left 36, 38

New Right (in FRG) 3, 35-48; developments since end of 1960 s 


\section{Index}

38-40; doctrinal foundations 42-6; genesis 36-8; ideological and propaganda assumptions $40-1$; influence of reunification 41-2

New Russian Nationalism: Imperialism, Ethnicity and Authoritarianism, The 161, 180n6

Niekisch Ernst 38

Nicholas I, emperor of Russia 162

Nietzsche, Friedrich 42, 44, 166

Niglia, Federico 19n7

Nikitorowicz, Andrzej 240n52

Nikitorowicz, Jerzy 240n44-6, 240n52, $242 \mathrm{n} 79$

Nizinkiewicz, Jacek 125n1

Nolte, Ernst 227n44

Norris, Pippa 59n36, 211, 215n52

Northern Ireland Assembly 96

Northern League (NL) see League

Norval, Aletta 103n4

Nowak, Anna 241n68

Nowak, Tadeusz 238n29

Noury, Abdul 192-3, 200n35

Nouvelle Droite 39, 54, 59n33

Nozick, Robert 113

NSDAP party 36

NSZZ 'Solidarność see solidarity

Obóz Narodowo- Radykalny (ONR) see National Radical Camp

Ochoa Espejo, Paulina 31n1

October Revolution 167

Oesh, Daniel 89

Office for Hungarians Abroad 136, 139

oligarchism 175

One Nation Tory, party 102

openness 7, 25, 28, 91, 251-3, 255, 257n4

Orbán, Viktor 67, 71, 74, 87, 131-5, 137, 139-41, 142, 207-11, 213n29, $214 \mathrm{n} 31,214 \mathrm{n} 44$

organisations $24-6,35-42,45-6,47 \mathrm{n} 9$, $76,77,80,81,101,119,120,151$, $162-6,168,171-8,186,210,220,228$, $233,236,238 \mathrm{n} 26,240 \mathrm{n} 55,248,250$, 254,257

Orsina, Giovanni 74n29

Ortega y Gasset, José 42, 203, 213n12

Ostiguy, Pierre $3 \ln 1$

Palingenesis 204

Palombella, Gianluigi 225n3

'Pamyat' see National-Patriotic Front 'Pamyat'

Pan-Slavism 161, 162
Panarin, Aleksandr 170

Pankowska, Maria 75n43

Pankowski, Rafał 48n22, 186, 199n8

Pannullo, Antonio 74n39

Paoli, Simone 74n29

Pappas, Takis S. 89n13, 212n11, 225n13

Parkes, Roderick 19n4

Pasquinucci, Daniele 2, 11-21, 74n40

Passarelli, Gianluca 3, 76-89

partnerships 29, 80, 122, 237

partocracy 116, 117

Party for Freedom (PVV), Netherlands 179, 190-1

patriotism $64,92,95,114 \mathrm{n} 1,117,119$, 158n31, 172, 228-42; see also Prawo i Sprawiedliwość (PIS)

Paul VI, Pope 257n2, 257-8n8

peasantry 166

Pech, Laurent 225n6, 226n27

Pegida 179

Pelinka, Anton 46

Pellicciari, Angela 21n40

Penn, Alfred Wayne 202, 212n3

pensions 62, 195

Penz, Johann 38

People of Freedom, The 78, 190-1

Perrineau, Pascal 56n2

Peter, Pope 245, 247

Peters, Jan 47n11

Petrović, Ivica 158n33

Petö, Andrea 7n2

Pew Research Center 176

Pfahl-Traugheber, Armin 47n4

Philip V, King 107

Pflüger, Friedbert 48n16

Pichon, Olivier 58n26

Piekalkiewicz, Jaroslaw 202, 212n3

Piers Ludlow, N. 20n20

Pierzchalski, Filip 145n39, 238n29

Pilarska, Justyna 105n26

Pilkington, Colin 104n15

Pin, Andrea 225n13

Piñar, Blas 68

Piontek Eugeniusz 257n7

Pirro, Andrea L. P. 7n2, 31n1, 199n3

PiS government 6, 220; see also Law and Justice

Plattner, Georg 186, 199n9

Plenge, Johann 41

Pleven Plan 11

pluralism 28, 29, 43, 44, 47n4, 92-3, 150, 186, 202, 253, 254

Poggiolini, Ilaria 20n20

Pöhlmann, Siegfried 38 
Pokret Socijalista (PS) see Movement of Socialists

Poland 203, 209, 216-22, 224; see also Kukiz'15, Law and Justice (PIS)

Poland Together party 119

Polak, Grzegorz 257n1

political formations $3,119,125$

politicians $2,4,14,15,52,54,60,63$, $80,82,83,101,102,106-7,117,121$, $123,130,135,137,138,142,144 \mathrm{n} 28$, $147,148,155,167,169,171,232$, 239n32, 254

Polo delle Libertà, party see The People of Freedom

Polska Razem (PR) see Poland Together

Potkin, Aleksandr see Belov, Aleksandr

Potkin, Vladimir see Basmanov, Vladimir

Prawica Rzeczypospolitej (PR) see Right Wing of the Republic

popular culture $18,143 \mathrm{n} 15$

popularism, right-wing 22; construction 22-4; crises and rise Euroscepticism 24-5; EU as cash machine 26-7; EU elites 25-6; EU values and Euroscepticism 27-8; heart of Europe 28; ontological security and tradition 28-31

populism $3,6,22,31,35,71,77,79,80$, $82,85,117,124,140,145-7,157,202$, 205, 211, 216, 217, 219, 222-5; car emissions 194-5; defining populism 185-187; in the EP 189-92; gender equality 195-6; immigration 196-7; methodology and data 188; populists and the EU 187-8; populist parties 185, 197-9; radical-right populism (see right radical); Right2Water 193-4, 198; voting behaviour 188, 192-9 post-fascist right $60,63,68,73 \mathrm{n} 13,87$ poverty 17, 62, 94, 105n31, 168, 195, 233

Powell, Charles D. 14-15, 20n22

power $5,6,14,26,38,39,41,51-3,76-8$, 81, 83, 116, 123, 129, 132, 164, 165; English nationalism 93, 96

Pozo, Gonzalo 143n15

Pożarlik, Grzegorz 6, 202-15

Prague Declaration 70

Prawo i Sprawiedliwość (PIS) see Law and Justice

press $7 \mathrm{n} 1,7 \mathrm{n} 2,15,19 \mathrm{n} 8,19 \mathrm{n} 9,20 \mathrm{n} 18$, $31 \mathrm{n} 1,31 \mathrm{n} 3,47 \mathrm{n} 8,57 \mathrm{n} 7,60,89 \mathrm{n} 12$, 111, 120, 132, 162; see also media prestige 99,100
Prison of the Nation, The 174

prison sentences 112

prisoners, political 112

privatisation 175, 188, 193, 197, 198, 254; water 188,193

privileges $26,63,93,97,98,101-2,107$,

$113,132,135,210$

products, EU 123

professions 99-100

Prohüber, Karl-Heinz 47n9

Prokhanov, Aleksandr A. 170-171

propaganda $11,12,14,15,18,25,36$, 40-3, 46-7, 61, 79, 82, 83, 121, 176, 238n29, 239n32; NR 40-1

propaganda, state 25

prosperity, economic 12, 24, 93

Proudhon, Pierre-Joseph 44

Prowe, Diethelm 48n20

public expenditure 118

public health 111,123

public opinion $12,18,53,60,98,101$, 148,175

public spending 87

publishers 7, 40

Puigdemont, Carles 108, 112

Pujol, Jordi 114n2

pujolism 107

Putin, Vladimir 63, 87

Pytlas, Bartek 57n12, 58n19

races $43-4,93,157$

racial hierarchies 93

racism 43, 105n28, 133, 168, 172

Rafael Santi 252

Rallo Michele 68, 74n30

Ramsden, John 19n6, 20n27

Ranger, Terrence 30, 31n11

Rassemblement National (RN) see National Rally

Ratzinger Joseph see Benedict XVI, Pope

Rauchegger, Clara 227n34

Rayner Gordon 105n39

Reagan, Ronald 61

Real Politics Union (Poland) 118-19

Rebotti, Massimo 72n2, 72n9

Rebuilding Russia 164

refugees 23-5, 42, 46, 87, 104n12, 123, 139, 196, 198, 201n39, 239n32, 249, 260n33; New Right (in FRG) 3, 35-48

Reinhardt, Udo 39

religion (faith) 137, 139, 164, 230-1, 233, 170, 252; Russia 176-7; see also Christianity 


\section{Index}

remembrance 64, 129, 230, 234

Renan, Ernest 64-5

Renew Europe 189, 190-1, 192

Republikaner (die) 36

Republikanischer Studentenbund 38

research 2, 7n2, 16-17, 19n17, 30, 35, 40, 46, 48n18, 50, 57n11, 58n21, 90, 96, 100, 104n18, 104n19, 105n35, 134, $138,139,144 \mathrm{n} 29,144 \mathrm{n} 36,144 \mathrm{n} 40$, $147,149,157 \mathrm{n} 1,157 \mathrm{n} 12,158 \mathrm{n} 18,160$, 161, 175, 176, 179, 185, 188, 193, 199, 199n9, 200n19, 212, 225n15, 228, $238 \mathrm{n} 15,257 \mathrm{n} 4$

resources $26,50,51,55-6,58 \mathrm{n} 19,76$, $103,141,155,166,175,179,187$

responsibility $29,98,101,112,148,196$, 222, 228, 234, 240-1n58

Reungoat, Emmanuelle 58n19, 58n27, 59n29, 59n37, 59n39

reunification $3,14,15,41-2,133,250$; NR 41-2

revolts $36,38,79-80,105 n 36,203$, 213n12, 224

Revolution 1848-49 in Hungary (Spring of Nations) 128

Rey, Pierre 20n 20

Rheinkrise 13-14

Ridley, Nicholas 20n27

right radical (extreme) 3, 6, 7, 31, 35, 38, $46,48,57-9,73,80-1,83,85,87-9$, $92,94,105,118-20,126,138,147$, $149,155,158,169,179,180,182,186$, 189, 200, 201

Right2Water 193-4, 198

Right Wing of the Republic (Poland) 119

riots 177

rituals, secular 64

Rodina, club 163, 168

Rodina Party see Homeland

Roger, Antoine 7n1

Rohmoser, Günther 40

Rogozin, Dimitry 168-9, 171

Rokkan Stein 88n2

Romania 128, 129, 132, 134, 135, 139, $142,144 n 27,214 n 31,225 n 4,259 n 18$

Rooduijn, Mathijs 89n18

Rother, Bernd 20n20

Rougier, Louis 42

Rösti, Albert 46

Rüger, Jan 19n5

rule of law 26, 203, 207-9, 216-17, 224-5; entanglement 219-21; European legal war 222-4; hybridity 217-19; language of constitutionalism 221-2

Rule of Law Framework (EURLF) 219

Rummens, Stefan 186, 199n5

Russia (Soviet), 160-82

Russia Under Avalanche 164

Russia Will Be Freed By Our Forces (a Russian political association) 175

Russians (the), (a National-Socialist association) 173,178

Russian Doctrine 169

Russian National Democrats 174

Russian National Unity (RNU) 171-4, 178

Russian Nationwide Union (RONS) 175

Russian Orthodox Church 176

Russian Revival, party 172

Russophobia 165-6

Rydliński, Bartosz 145n39, 238n29

Saage, Richard 48n19

Sadowski, Grzegorz 48n27

Sadurski, Wojciech 227n41

Sajó, András 227n49

Salvini, Matteo 3, 46, 71, 72n2, 76-89, 120

Salvini's League 3, 46, 76, 86, 120; early years to $201277-80$; in perspective 2, 7n2, 11-14, 26, 27, 51-2, 54, 58n15, 58n20, 86-8, 112, 116, 143n21, 160, $161,170,171,177,179,206,213 \mathrm{n} 16$, 214n $44,216,218,221-3,245-8$, 252-4; radical-right populism 80-6; see also League

Samoobrona Rzeczypospolitej Polskiej (SRP) see Self-Defence of the Republic of Poland

Samostalni DSS (S DSS) see Independent DSS

Sanacja 209

Santi, Marco 46

Santi, Rafael 252

Sargent, Lyman Tower 103n4

Sarkowicz, Hans 47n5

Sartori, Giovanni 127n39

Sartre, Jean-Paul 42

Savelyev, Andrei 169

Scheppele, Kim Lane 143n10, 225n4, 225n6, 225n10, 226n 27

Schields, James 50, 58

Shils, Edward 30, 31n10

Schmitt, Carl 36, 40, 41, 45, 48n24, $48 \mathrm{n} 25,213 \mathrm{n} 24,223$

scholars 15, 17, 40, 50, 105n26, 128, 144n36, 169-70, 185, 202, 203, 212 
Schönborn, Meinolf 39

Schönekäs, Klaus 47n6

School of Athens, The 252

Schramm, Tomasz 257n6

Schrenck-Notzing, Casper 39

Schüddekopf, Ernst-Otton 35, 47n2

Shuibhne, Niamh Nic 226n16

Schulte-Cloos, Julia 58n19

Schulz-88 (a Russian national-socialistic organization) 173

Schulze, Thomas 39

Schuman, Robert 11, 16, 199n9

Scotland 95-8, 102, 104n21

Scottish Parliament 96

Scottish National Party 97

Scully, Richard 19n5

Second World War 13, 18, 36-8, 42, 44, $51,52,95,148,217,245$

secularism 27, 65, 66, 176, 247, 256

security $1,12,28-31,63,68-70,73 \mathrm{n} 14$, 76, 79, 85-6, 104n12, 110, 111, 117, $118,123,138,148,165,187,207,211$, 220, 231, 240n51, 250, 255

Security Decree 76

security, ontological 28-31

See-Oglu, Oiun Adigzi 140

Self-Defence of the Republic of Poland, party (Poland) 119

self-esteem 100

Serbia 5, 79, 146-59; EU intergration 153-6; Euroscepticism 149-53;

historical background 147-9

Serbia Demokratska Stranka Srbije (DSS) see Democratic Party of Serbia

Serbian People's Party (SNP) 150, 151, 152, 153, 155, 156, 158n21, 158n34, 159n46

Serbian Progressive Party (SNS) 148, 150-3, 151, 156, 158n21

Serbian Radical Party (SRS) 147, 150, 151, 153, 155, 156, 159n44

Serricchio, Fabio 89n17

Shafarevich, Igor Rostislavovich 164-6

Shalimova, Nadezhda V. 176

Shils, Edward 30, 31n10

Shiropaev, Aleksey 174, 178

Shopenhauer, Arthur 166

Simonovich-Nikshich, Leonid

Donatovich 176

Simonsen, Sven Gunnar 161

Sinčić, Ivan Vilibor 120

single currency 17,81

Single European Act 51-53

Single Market 17
Skorka Abraham 259n22

Slavic Power 173

Slavic Union 173, 178

Slavophilism 161, 162

slogans 4, 38, 39, 41-3, 46, 61, 67, 71, 81, 94, 109, 116, 117, 121, 122, 135, 164, 169, 176, 230, 232, 233, 238n26, 246; Poland 5, 6, 22, 25, 117, 122; Russia 164, 169

Slovakia 66, 82, 134, 135, 139, 142, 144n27, 190-1

Słodkowska, Inka 158n36

Słomczyńska Małgorzata Izabela 241n63

Smelser, Neil J. 142n2

Smith, Anthony D. 31n4, 90

Smolar, Eugeniusz 238n20

social programmes 62

social security 85

social welfare $230,238 \mathrm{n} 28$

socialism 36, 39, 41, 46, 137, 141, 165,186

Socialist Party of Serbia (SPS) 147, 148, $151,152,158 \mathrm{n} 31$

Socialist Revolutionary Party (Russian Empire, Soviet Russia) 166-7

Socialist Revolutionaries 166-7

Solidaristische Volksbewegung 39

solidarity 7, 26, 27, 37-9, 44, 61, 93, 141, 162, 196, 204, 207, 209, 230, 232, 234, 237, 238n18, 240-1n58, 246, 251, 256, 257

Solidarna Polska (SP) see United Poland Soloukhin, Vladimir 163

Solzhenitsyn, Aleksandr Isaevich 164-6

Sombart, Werner 41

Sondel-Cedarmas, Joanna 1-7, 60-75

Sonervend, Pál 225n4, 227n39

Sorel, George 42, 44

Sosnowski Leszek 257n5

South Korea 11

soveregnism $3,83,85,86$

sovereignty $27,45,49,53,54,56,85$, $109,118,137$; Brothers of Italy $60-5$, 67-8; Law and Justice 207-9; National Rally $52-3,55$

Sozialrevolutionäre Arbeiterpartei 39-40

Spain 4, 39, 46, 67, 106, 108-11, 114n6, 114n7, 190-1

Spanish Constitution (1978) 106, 108,110

speaking $39,51,117,128,205-7$

special relationship 18

Spengler, Oswald 37, 40, 41, 43

Spiró, Peter J. 143n14 
Spitzer, Leo 142n3

Srpska narodna partija (SNP) see Serbian People's Party

Srpska radikalna Stranka (SRS) see Serbian Radical Party

stability, political 12

standards 62, 100, 146, 161-3, 194, 208, $217,218,220,221,224,226 \mathrm{n} 22$

Stanley, Ben $31 \mathrm{n} 5,212 \mathrm{n} 8$

Startin, Nicholas 20n28, 31n2, 58n20, 59n40, 159n 49

status $5,24,25,46,52, \mathbf{8 4}, 90,92-4$, $130,131,146,148,149,205,218,231$, 236, 249

Stefanoni, Franco 127n27

Stern, Fritz 14

Stears, Marc 103n4

Stojanović, Milica 158n30

Stojić, Marko 149, 156, 157n3, $158 \mathrm{n} 19,159 \mathrm{n} 48$

Stone, Jeanne C Fawtier 104n5

Stone, Lawrence 104n5

Stone, Marla 20n22

Stone, Norman 14

Storace, Francesco 73n11, 73n17

Stöckicht, Peter 37

Stöss, Richard 47n10, 48n18

Strasser, Otto 37

Stronnictwo Pracy (SP) see Labour Party (Poland)

studies 19n3, 19n16, 30, 44, 46, 50, 57n7, $57 \mathrm{n} 10,57 \mathrm{n} 11,57 \mathrm{n} 12,58 \mathrm{n} 18,59 \mathrm{n} 33$, 89n10, 89n19, 97, 105n31, 161, 162, 171, 192-3, 199n5, 199n9, 200n21, 200n35, 213n24, 213n26, 214n32, 216, 217,235

Styczyńska, Natasza 5, 31n2, 146-59

Suffocation of Democracy, The $212,215 \mathrm{n} 55$

superiority $23,66,114 \mathrm{n} 1,168,236$

supremacy $14,17,18,119,223$

surveys $83, \mathbf{8 4}, 97,98,100-1,104 \mathrm{n} 22$, $104 \mathrm{n} 24,105 \mathrm{n} 38$

Swinfort, Steven 104n21

Swiss People's Party 46

symbols $61,64,66,85,87,91-2,101$, 137, 140, 167, 179, 209

Symenenko Club 38

Szabó, Ildiko 143n24

Szacki, Jerzy $30,31 \mathrm{n} 10$

Szczerbiak, Aleks 7n1, 57n13, 75n46, 126n23, 149, 157n13, 229, 238n15

Szerlag, Alicja 105n26

Szikra, Dorottya 207, 214n30, 214n31
Szilágyi, Anna 210, 214n46, 245n49

Szostkiewicz Adam 241n66

Sztompka, Piotr 142n2, 206-7, 213n27

Szulc, Anna 241n69

Śledzińska-Simon, Anna 226n18

Śpiewak, Paweł 230, 238n27

Šešelj, Vojislav 148, 150, 152, 155,159 n 43

Tacik, Przemysław 6, 216-27

Tadić, Boris 148

Taggart, Paul 7n1, 31n1, 57n13, 58n21, 75n46, 126n20, 126n21, 126n23, 149, 157n13, 199n3, 229, 238n15

Taguieff, Pierre-André 59n33

Tannock, Stuart 105n31

Tarchi, Marco 73n13, 73n14

tariffs 62

taxes $61,62,70,85, \mathbf{8 6}, 97,118,119$

Tellér, Gyula 128, 143n11

Terlikowski, Tomasz 257n4

Termann, Jochen 48n23

terrorism $63,71,177,223,252,255,256$

terrorists 24,25

Tesi di Trieste 61, 64, 66, 68, 73n15, $73 \mathrm{n} 22,73 \mathrm{n} 23,74 \mathrm{n} 27$

Thatcher, Margaret 14-15, 19n17, 20n19, 20n20, 20n27, 102

Third Reich 11, 15, 16, 18, 35, 36, 40, 44, 230

Three Thousand Years' Riddle, The 165

Thule-Seminar 41

Thulesen, Kristian 46

Timbro 120

Tisier-Vignancour, Jean Louis 68

Tismăneanu, Vladimir 225n9

Todd, Emmanuel 15, 20n26, 20n30

togetherness 116-17

Tokarczuk, Olga 239n34

Topaloff, Liubomir K. 7n1

Tornielli, Andrea 258n9, 259n18

Totalitarianism 40, 45, 164, 170, 172-3, 202, 204

Tóth, Csaba 225n5

Tóth, Gábor Attila 133, 143n12, 225n1, 225n4

Tölgyessy, Péter 144n26

trade $12,20 \mathrm{n} 27,25,62,82, \mathbf{8 4}, 95,146$, $157 \mathrm{n} 2,193,209,255$

traditionalism see popularism, right-wing

traditions 64, 65, 79, 139, 140;

Russian 161-3

transport 69, 118, 140 
Transylvania 135, 144n27

Treaty of Dublin 87

Treaty on European Union 203, 226n22, 226n30, 242n88

Treaty of Lisbon 27-8, 80, 228

Treaty of Trianon 128-130, 132, 135, 138

Tremonti, Giulio 70

Trenz, Hans-Jorg 157n12

Trevor-Roper, Hugh 14

Trianon, Treaty of 128, 132-3, 135, 138, $142,143,145$

Tronconi, Filippo 88n7

Trudić, Momir 158n32

Tsiobanidis, Evangelos 120

Trotsky, Leon 172

Trump, Donald 62, 63, 87, 215n52

Tuorto, Dario 3, 76-89

Turanism, neo-turanism 138-9, 142

Turkey 5, 66, 138

Turowski Gabriel 257n5

Tushnet, Mark 226n17

Türsan, Huri 88n6

Two Hundred Years Together 164

Tyutchev, Fyodor 162

UKIP 90-105, 190-1, 193

Ukraine 128, 132, 138, 139, 141, 164, $168,172,176,177$

Unabhängige Arbeiter-Partei (UAP) 37

unemployment 29, 37, 62, 69

unification: German reunification 3, 13-15, 36, 41-2; Italy 13, 17; see also national unity, Hungarian

Unia Polityki Realnej (UPR) see Real Politics Union

Union of Orthodox Banner Bearers 176

Union of Orthodox Citizens 176

United Poland, party 119

unity $3,6,26,38,45,51-3,63,91,94,110$, $122,131-3,135,140,170-2,222,232$, $246,247,249-51,253,254,256,258 \mathrm{n} 17$

Universal Declaration of Human Rights 104n $11,233,240 \mathrm{n} 58$

universalism 65, 66, 162, 246, 254

universalism, Christian 246

Urban, George R. 14, 20n19, 105n26

Urbanek, Arkadiusz 104n26

urbánusok 130-1

Urbinati, Nadia 145n38

Usherwood, Simon 31n2, 159n49

Uvarov, Sergey 176

Valli, Aldo M., 258n14, 258n16

Vlandas, Tim 57n7
Valance, Georges 19n10

value (worth) 100

values $1,5,6,12,26-9,43,70,79,94$, $97,100,102,111,130,132,154,165$, 168, 169, 174, 175; Hungary 130, 141; Poland 113, 203

Vanhecke, Frank 46

Vanke, Jeremy 19n9

Varsori, Antonio 74n29

Vasilopoulou, Sofia 57n11, 57n12, 58n16, 149, 157n7, 158n17, 158n18

Vasilyev, Dmitry 163, 164, 171

Vasin, Yuri 172

Verbeek, Bertjan 89n18

Verzichelli, Luca 89n8

Venice Commission 132, 226n20

Vienna Declaration (1993) 112

Villiers, Philippe de 16, 20n32-4

violations 112, 133, 166, 219-20

violence $29,111,179,195,233,241 \mathrm{n} 67$, 249-50, 252-4

virtual nationalism 134

Virtue of Nationalism, The 65

Visegrad Group 28, 66, 67, 70

Vityaz 163

Vizi, Tamás L. 143n5

Vlaams Belang 82, 190-1

Vlaams Bloc, party 46

Volkspartei Deutschnationale

(DNVP) 36

Vona, Gábor 134

Voprosy nacionalizma 175

voters 59 n $36,78,83, \mathbf{8 4}, \mathbf{8 6}, 88,96,98$, 101, 103, 110-12, 116-18, 123, 133, $135,150,157,208$

voters (voting) 89n11, 96, 98, 121, $124,133,135,150,157,188,192-9$, 200n35, 208, 211

VoteWatch database 188, 197, 198, 201n41

voting 89n11, 96, 98, 99, 121, 124, 133, 188, 192-9, 200n35, 201n41, 211

Vučić, Aleksandar 149, 150, 152, 158n29

Vujačić, Marko 150, 158n22

Vox party 46, 67, 191

wages $62,99,100$

Walecka, Katarzyna 126n6

Waldmann, Gert 38, 43n-5, 48n21

Walicki, Andrzej 161, 180n1

Walker, Adam 46

Wallerman Anna 227n34

Wallerstein. Immanuel 225n11

Waldenberg, Marek 240n53

Wandel, Laurent van de 19n13 


\section{Index}

wars $6,11,13,15,18,19 \mathrm{n} 6,20 \mathrm{n} 20$, 36-45, 64, 79, 95, 107, 131, 137, 156, 159n43, 169, 216-27

water privatisation 193

Weber, Thomas 19n5

wealth $63,93,117,251-2$

Weimar Republic 35, 36, 131

welfare systems 62, 85; Scottish 97

Wellings, Ben 19n17

Werner, Annika 57n12, 58n20, 201n36

Wilde, Pieter, de 157n12

Willms, Bernard 40

Wilson, Carole J. 57n9, 57n11

Wir selbst 40

What Is Populism 202, 212n10

Wojtas, Kinga 126n6

Wolff-Powęska, Anna 46, 48n19, 48n26

Wolinetz, Steven B. 89n18

women 13, 25, 85, 195, 198, 231, 237,250

Woods, Roger 50, 58n17

work $15,16,18,35,62-3,90,91,99-100$,

105n $30,174,178,220,228,231,236,252$

workers $46,62,83, \mathbf{8 4}, 85,89$ n15, 99 ,

105n30, 105n31, 177

World Federation of Hungarians 136
Wrześniewska-Pietrzak, Marta 126n12

Wyn, Jones Richard 104n18, 104n19

Wysocka, Olga 126n20

xenophobia 46, 82, 103, 119, 133, 168-9, 217,239 n 34

Yavich, Lev 225n8

Yeltsin, Boris 163

Yermolaev see Ermolaev

Young, Hugo 20n21, 20n24

Young, Robert 91, 103n2

Yuri Levada Analytical Centre 175

Zaia, Luca 87

Zahradil, Jan 70

Zanatta, Loris 89n13, 124

Zaslove, Andrej 89n18

Zhirinovsky, Vladimir Volfovch 167-8

Zjednoczona Prawica 207; see also United Right

Zombori, István 143n6

Zuba, Krzysztof 229

Zulianello, Mattia 186, 190-1, 199n6, 200n16, 200n29

Živi zid see Human Shield 